RHOWENA JANE BARBOSA DE MATOS

\title{
Expressão de receptores metabotrópicos de glutamato no sistema visual de ratos e pintos após enucleação ocular
}

Tese de Doutorado apresentada ao Instituto de Ciências Biomédicas da Universidade de São Paulo para obtenção do Título de Doutor em Ciências (Fisiologia Humana). 
RHOWENA JANE BARBOSA DE MATOS

\section{Expressão de receptores metabotrópicos de glutamato no sistema visual de ratos e pintos após enucleação ocular}

Tese de Doutorado apresentada ao Instituto de Ciências Biomédicas da Universidade de São Paulo para obtenção do Título de Doutor em Ciências (Fisiologia Humana).

Área de Concentração: Fisiologia Humana Orientador: Luiz Roberto Giorgetti de Britto 
DADOS DE CATALOGAÇÃO NA PUBLICAÇÃO (CIP)

Serviço de Biblioteca e Informação Biomédica do

Instituto de Ciências Biomédicas da Universidade de São Paulo

(C) reprodução total

Matos, Rhowena Jane Barbosa de.

Expressão dos receptores metabotrópicos de glutamato nos sistema visual de ratos e pintos após enucleação ocular / Rhowena Jane Barbosa de Matos. -- São Paulo, 2007.

Orientador: Luiz Roberto Giorgetti de Britto.

Tese (Doutorado) - Universidade de São Paulo. Instituto de Ciências Biomédicas. Departamento de Fisiologia e Biofísica. Área de concentração: Fisiologia Humana. Linha de pesquisa: Comunicação celular no sistema nervoso: expressão e regulação dos receptores.

Versão do título para o inglês: Expression of metabotropic glutamate receptors in the rat and chick visual system after ocular enucleation.

Descritores: 1. Receptores de glutamato 2. Receptores metabotrópicos 3. Sistema visual 4. Plasticidade neuronal 5. Enucleação ocular I. Britto, Luiz Roberto Giorgetti de II. Universidade de São Paulo. Instituto de Ciências Biomédicas. Programa de PósGraduação em Fisiologia Humana. III. Título. 


\section{UNIVERSIDADE DE SÃO PAULO \\ INSTITUTO DE CIÊNCIAS BIOMÉDICAS}

Candidato(a): $\quad$ Rhowena Jane Barbosa de Matos

Título da Tese: $\quad$ Expressão dos receptores metabotrópicos de glutamato nos sistema visual de ratos e pintos após enucleação ocular

Orientador(a): $\quad$ Luiz Roberto Giorgetti de Britto

A Comissão Julgadora dos trabalhos de Defesa da Tese de Doutorado, em sessão pública realizada a ..................., considerou

\section{( ) Aprovado(a) ( ) Reprovado(a)}

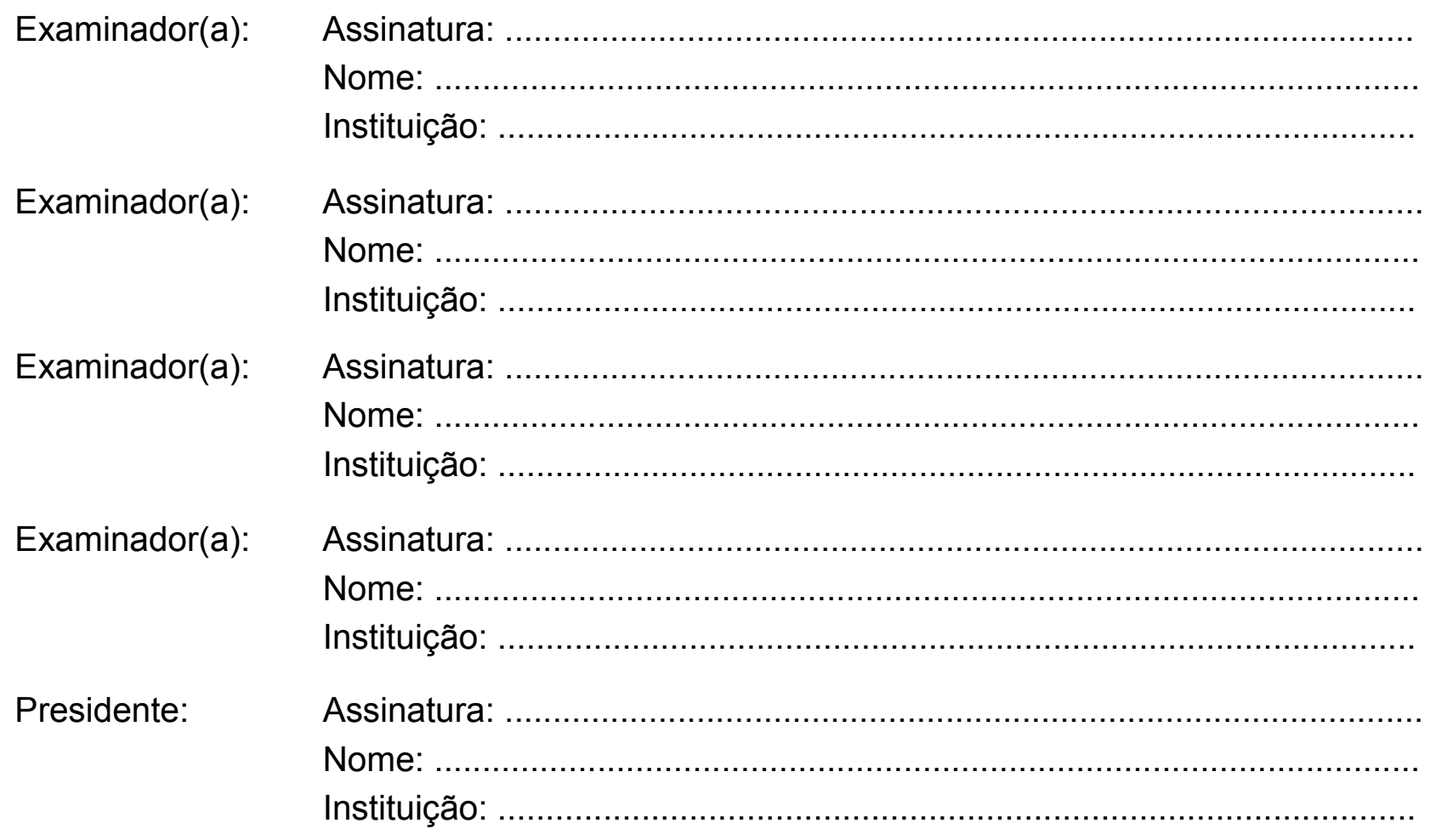




\section{DedicatóRIA}

Aos meus pais, que sempre foram exemplos de amor, dedicação, paciência, garra e coragem. Vocês são meus inspiradores dessa caminhada.

Aos meus oito irmãos, que sempre me incentivaram e injetaram uma dose de carinho em todos os momentos da minha vida.

A meus amigos sempre presentes, que me fizeram enxergar que na vida tudo é mais difícil e triste sem eles.

Ao Júlio e suas lindas filhas, Gabriela e Giovana, que me ensinam a amar. 


\section{AgRADECIMENTOS}

Agradecer transforma este momento da escrita em um filme que nos remete ao passado. Um filme que foi composto de momentos alegres, tristes, leves, densos, prazerosos, de lágrimas, de muitos sorrisos, de amor, de compreensão, de carinho e ternura, de companheirismo e solidariedade, de coragem e fraqueza, de austeridade e complacência, de descrença e fé. Momentos estes recheados de uma infinidade de sentimentos que nos enchem de experiências, de "tijolinhos" que nos dão alicerce para nos construir. Tais sentimentos são despertados por todos aqueles que aparecem na nossa vida e nos ensinam a arte de viver e crescer. Segundo Gonzaguinha, “..... aprendi que se depende sempre de tanta muita diferente gente, todas as pessoas sempre são as marcas das lições diárias de outras tantas pessoas....". Por isso, o filme se torna real porque dependemos sempre do outro e essa interação nos torna cheios de vida. Fazendo uma analogia com a fisiologia, somos uma parte integrada de um todo.

Agradeço ao Amor que é minha fonte de inspiração, tanto na vida científica como na pessoal.

Ao Prof. Britto, pela orientação, apoio, paciência, aprendizado e pela acolhida durante os cinco anos em seu laboratório. Com toda a certeza, a convivência foi frutífera, de grande aprendizado profissional e estará comigo onde eu estiver.

Ao Prof. Raul (UFPE), grande amigo, que sempre esteve ao lado dos seus alunos, apoiando e ensinando que não só a ciência é feita com amor e dedicação por inteiro, mas tudo o que nos propomos a fazer na vida. Ajudou-me a construir a base científica e humana. "A ciência é feita por seres humanos!"

À Prof ${ }^{-}$Karla Mônica (UFPE), minha grande amiga que me mostrou os primeiros passos no mundo da pesquisa, sempre me incentivando com paciência e dedicação. Exemplo de serenidade, seriedade, competência e doçura.

À Maru, a cidadã do mundo, pela amizade em todas as horas, parceira no trabalho e na vida. Versátil, destemida, dedicada, inquieta e feliz. Trabalhar com você é uma diversão. Você foi fundamental para que este trabalho se tornasse realidade. Obrigada mesmo por tudo!

Aos colegas do laboratório da "old generation": Andréa (garra e determinação), Adilson (alegria e prestatividade), Ivana (autenticidade e despreocupação), Nathalia (protetora e risonha), Samuel (prestatividade e amigo), 
Mauro (diversão e seriedade); e aos colegas da "new generation": Alexandre (amigo e obstinado), Rosana (companheira e doce), Ana (prestativa e sensível), Erika (forte e serena), Marina (protetora e sensível), Gabriela (emoção e seriedade), Vera (musical e tranqüila), Carol (doce e destemida), Daniel (dedicação e doçura), Renata (serenidade e emoção), Rodrigo (tranqüilidade e obstinação), Taísa (coragem e amiga), Carol e Guilherme (união e dedicação), Julian (destemido e parceiro), Daniele (serena e dedicada) e que entre conversas e choros, sorrisos e trabalho me ensinaram que trabalhar em equipe é muito salutar e que nos promove grandes parcerias e alegrias.

Aos amigos e irmãos Sandra, Carol, Matilde, Kiyomi e Ken, os meus eternos "anjos-de-guarda". Com vocês percebo que preciosidades passam no nosso caminho e deixam a vida mais brilhante e leve.

Ao Alan e July, companheiros cruspianos de toda as horas mesmo, obrigada pelo apoio em todos os momentos, pelas conversas filosóficas, pelos divertimentos, pelas palavras de incentivo e discussões proveitosas.... parceiros e amigos de importantes momentos, vou levá-los comigo aonde eu for.

Aos componentes do CoralUSP com regência do André Juarez, que durante três anos encantaram e deixaram meus dias mais leves e felizes. Vocês são exemplo de serenidade, competência e união. Com vocês tive momentos agradabilíssimos, cantando e sorrindo muito, e ainda tive grandes presentes como 0 Júlio e meus amigos inesquecíveis.

Ao Júlio Moreira, que despertou em mim novamente o amor. Um grande parceiro sábio e palhaço, em muitos momentos, companheiro sensível, grande homem. Ele entrou na minha vida como um grande presente e deixou os meus dias mais suaves e felizes, meu companheiro de todos as horas, que suporta todas as minhas ansiedades, inquietudes e trabalho. Você está sendo fundamental na minha vida. E a suas lindas filhas Gabriela e Giovana, que me receberam com carinho e doçura e que enchem minha vida de alegria. Como também, ao Seu Moreira e Dona Luci pelos momentos em família. Amo vocês.

Aos companheiros e amigos da UFPE, longas conversas e longas jornadas de trabalho, digo "descontração", o meu muito obrigada: Wylla, Soninha, Júnior, Lúcia, Rogério, Beth e Cristiano......aos amigos baianos que encontrei por lá e ainda hoje vejo-os por aqui e por Salvador: Deny, Tereza e família, Jairza e Maira... e 
tantos outros que me incentivaram de uma maneira ou de outra, não os esqueço jamais.

À Wilma, Rosana, Renata Frazão, Renata Vasconcelos, Leila, Luciana Pinato pelos momentos de alegria, descontração, solidariedade e de muitos sorrisos.

À Gisele Braga, à Vera Cury, à Fabiana, ao Flávio, à Simone, ao Anderson, à Daniwey, à Márcia, ao Jarlei, à Tavane e ao Augusto, pela grande amizade e incentivo de todas as horas, ajudas experimentais, conversas fundamentais e muitas gargalhadas.

Aos amigos Fátima, Danilo e Marco, família unida e feliz. Obrigada pelas palavras certas nas horas certas, pelo carinho dedicado a mim sempre. Seus inesquecíveis abraços, juntos com os acolhedores de Ana (cheios de energia), Leila, Cláudia, Patrícia e Eliana deixaram meus dias mais reconfortantes e mais leves durante a minha permanência no ICB. O carinho nos deixa mais fortes e confiantes.

À Prof ${ }^{a}$ Dânia Hamassaki-Britto, a Prof ${ }^{a}$ Sara Joyce Langnado e ao Profo Newton Canteras pelas valiosas críticas, dando mais consistência ao trabalho e norteando-o ainda mais. Obrigada pelas contribuições!

Ao Profo Marcus Vinícius Baldo, pela amizade, ajuda e ensinamentos estatísticos.

À Prof ${ }^{\mathfrak{a}}$ Carla Roberta, Teca, Anderson e Mário, pelo auxílio nos experimentos de immunoblotting.

Aos funcionários da Biblioteca e da secretaria deste departamento, que estiveram sempre dispostos a fornecer orientações acerca do material didático e dos trâmites burocráticos.

Aos animais que contribuíram indiscutivelmente para a obtenção deste trabalho.

Aos órgãos de fomento, pelo auxílio financeiro.

Enfim, a todos o meu muito obrigada! 
“Uau! Ontem nevou para valer! Não é maravilhoso? Tudo que era familiar desapareceu! O mundo parece novinho em folha! Um ano novo! Uma chance para recomeçar do zero! È como ter uma folha enorme e branca pra gente desenhar! Um dia cheio de possibilidades! O mundo é mágico...... Vamos fazer uma exploração!" 


\section{SUMÁRIO}

RESUMO

ABSTRACT

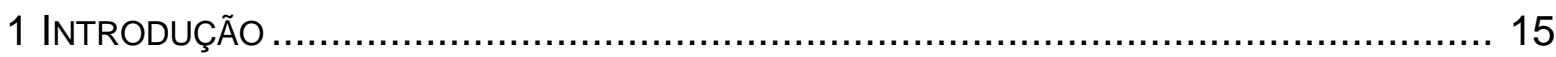

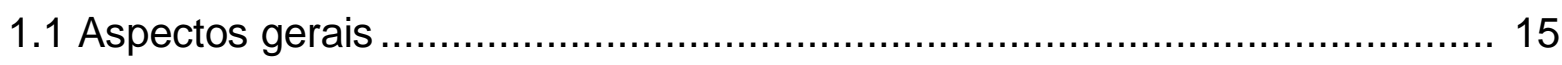

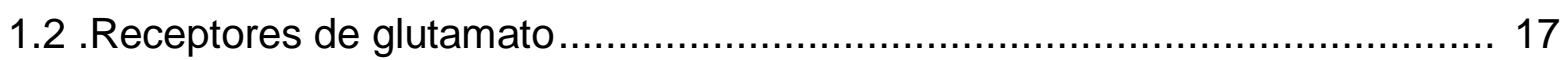

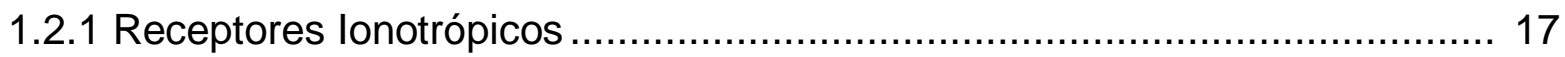

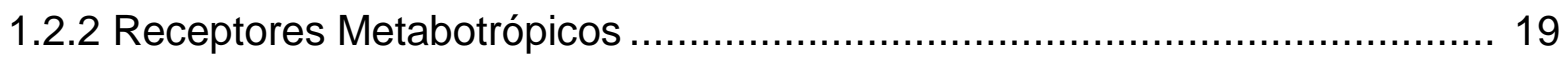

1.4 estruturas anatômicas do sistema visual de ratos e pintos.......................... 24

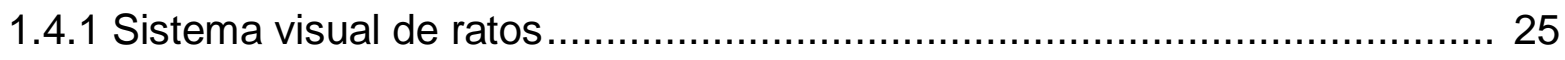

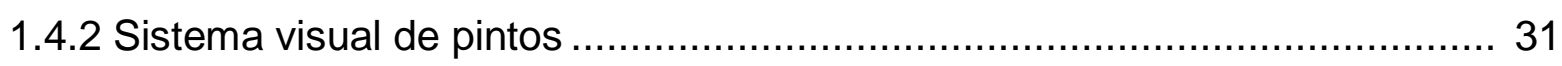

1.5 Os receptores metabotrópicos no sistema visual .................................. 34

1.6 Receptores metabotrópicos de glutamato e plasticidade neuronal ................. 37

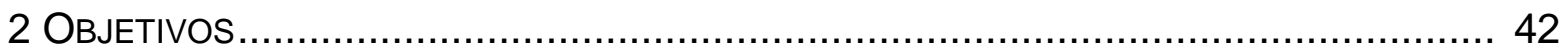

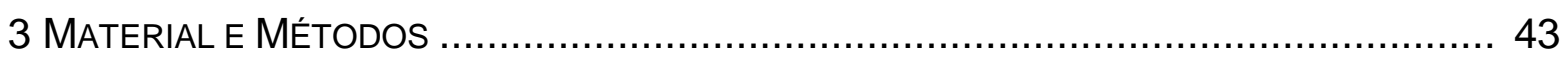

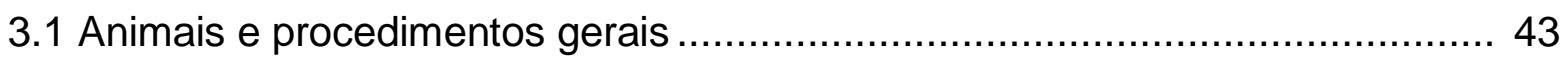

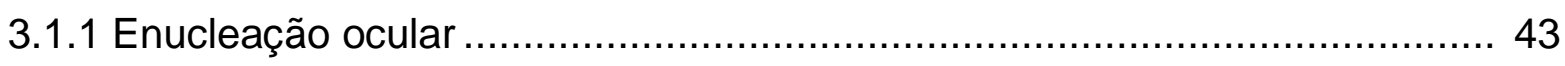

3.2 Detecção das células com fragmentação de DNA .................................. 44

3.3 Detecção de degeneração de fibras neuronais ...................................... 45

3.4 Alteração de neurópila no colículo superior de rato por injeção de BDA ........ 46

3.5 Quantificação da expressão gência de mGluRs por RT-PCR em tempo real .. 47

3.6 Quantificação de proteínas mGluRs por immunoblotting........................... 49

3.7 Análise da expressão dos mGluRs da gliose reativa pro imuno-histoquímica . 50

3.7.1 Identificação de neurópila em pintos por injeção de biocitina "in vitro" ......... 52

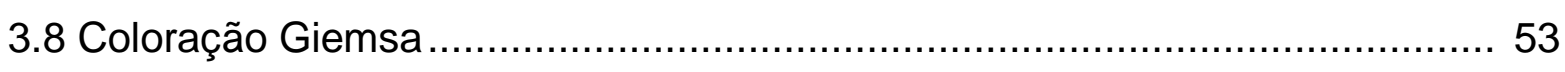

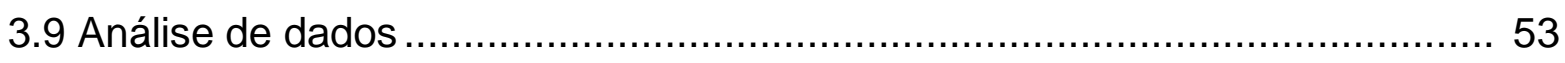

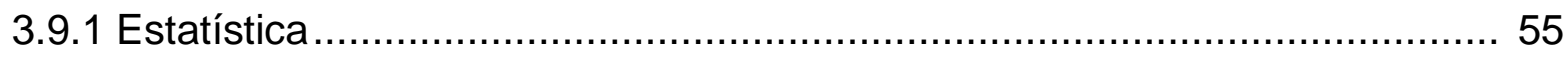

4 Resultados dA ENUCLEAÇÃO OCULAR EM RATOS E PINTOS.............................. 56

4.1 Morte celular e enucleação ocular em ratos e pintos ............................... 58

4.2 Degeneração de fibras após enculeação ocular em ratos e pintos.................. 61

4.3 Modificação na organização sináptica no colículo superior de ratos ............... 65

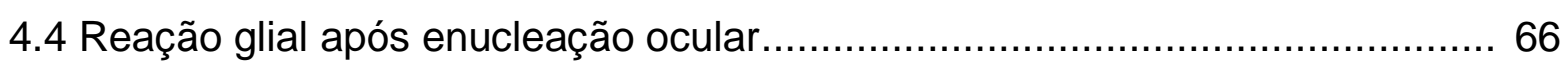


4.5 Avaliação da experiência gência, proéica e da distribuição dos mGluRs no colículo superior de ratos. 69

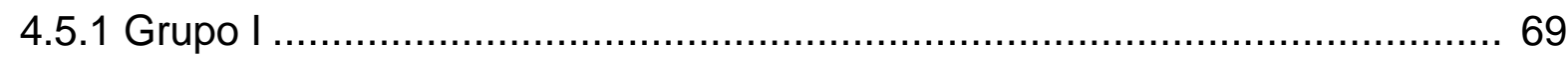

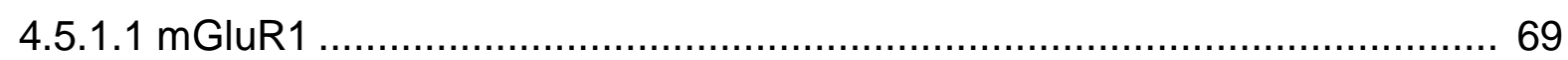

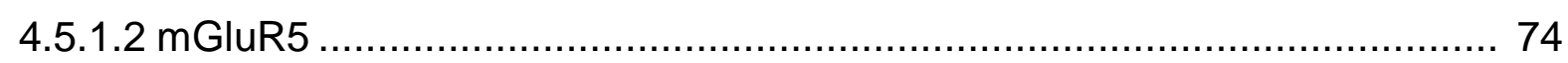

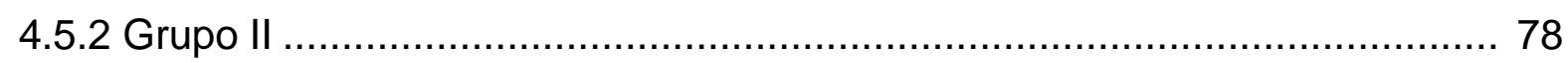

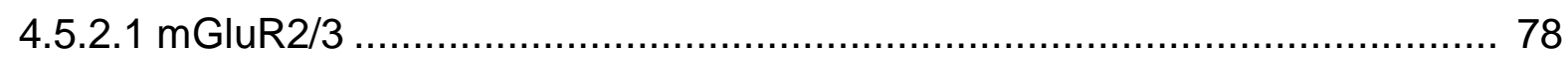

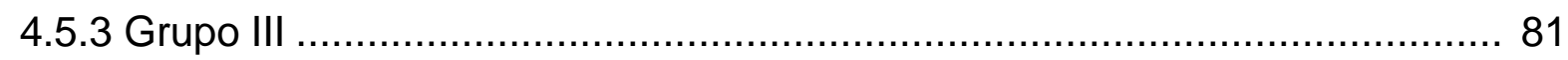

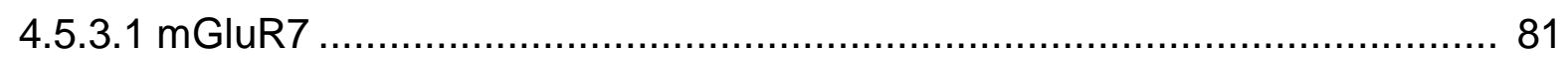

4.6 Resumo dos resultados para o colículo superior........................................ 85

4.7 Avaliação da expressão protéica e da distribuição dos mGluRs no núcleo

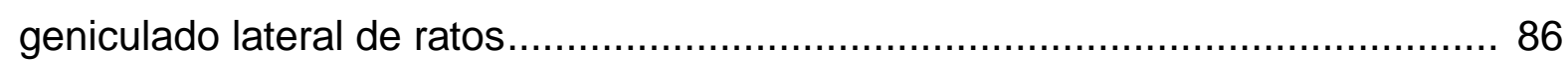

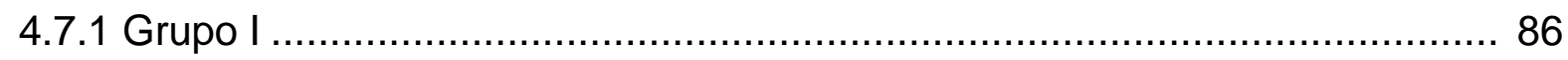

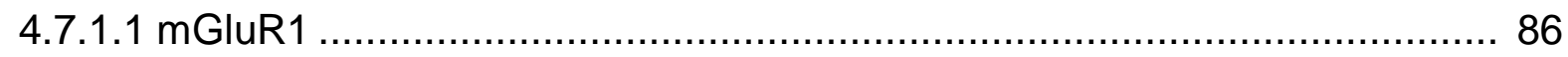

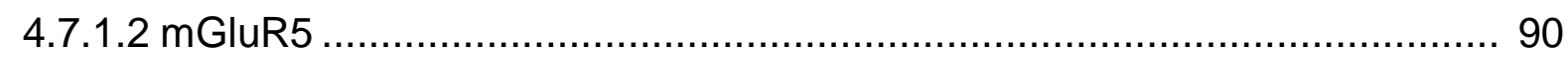

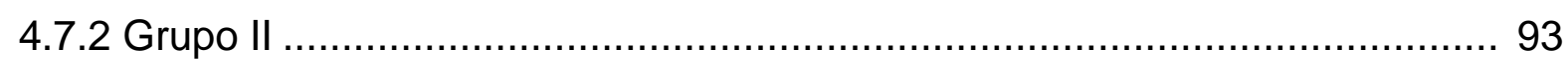

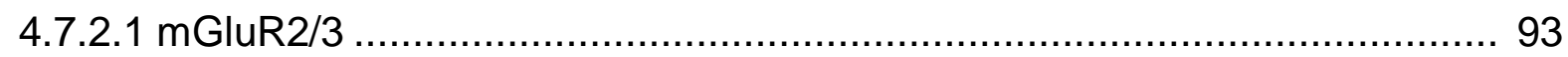

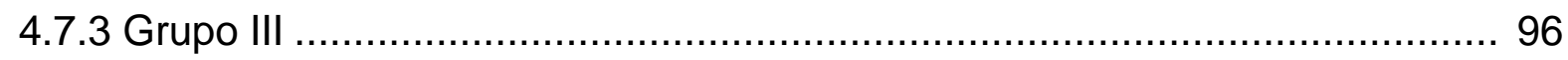

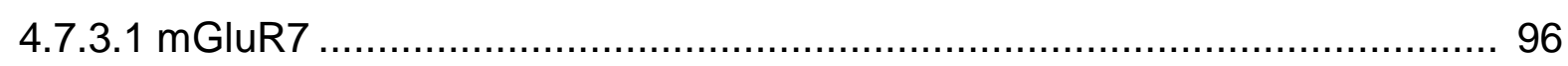

4.8 Resumo dos resultados para o colículo superior.......................................... 99

4.9 Avaliação da expressão protéica e da distribuição dos mGluRs no tecto óptico de

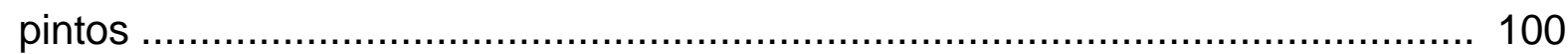

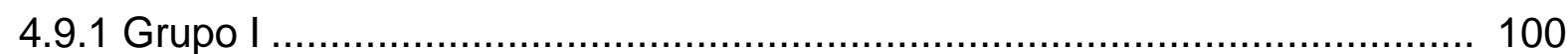

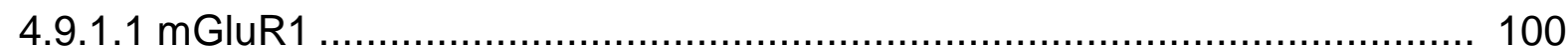

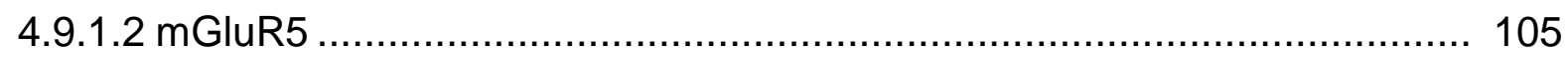

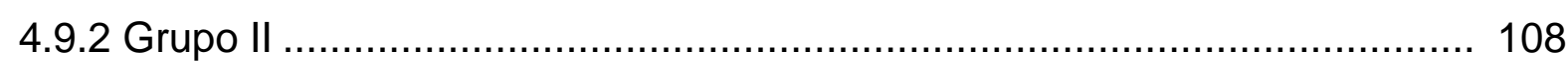

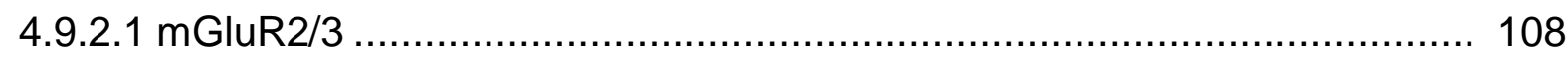

4.10 Resumo dos resultados para o colículo superior ..................................... 113

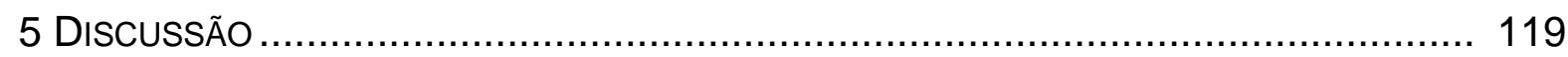

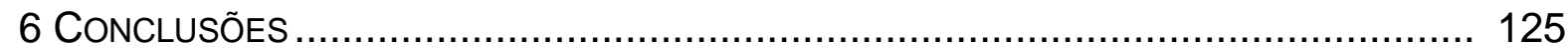

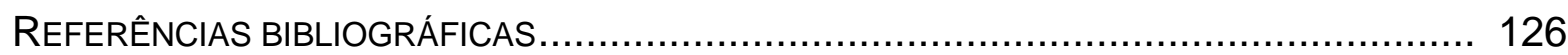




\section{Resumo}

Matos, RJB. Expressão dos receptores metabotrópicos de glutamato nos sistema visual de ratos e pintos após enucleação ocular [Tese]. São Paulo: Instituto de Ciências Biomédicas da Universidade de São Paulo; 2000.

Os receptores glutamatérgicos metabotrópicos (mGluRs) estão envolvidos nos processos de plasticidade neural, neurodegeneração e neuroproteção. Avaliamos neste estudo a expressão de mGluRs no sistema visual de ratos e pintos antes e após desaferentação por enucleação ocular. As áreas estudadas foram o colículo superior (CS) e o núcleo geniculado lateral (NGL) de ratos e o tecto óptico $(\mathrm{TeO})$ de pintos. Utilizamos ratos Wistar e pintos (Gallus gallus) adultos que foram anestesiados e submetidos a enucleação ocular unilateral. Após diferentes intervalos de sobrevida (1, 7, 15 e 30 dias), os animais foram anestesiados, perfundidos com salina e paraformaldeído (2\%), e seus encéfalos crioprotegidos e cortados. Os cortes foram submetidos a imuno-histoquímica para detecção dos receptores mGluR1, mGluR2/3, mGluR5 e mGluR7. Para procedimentos de immunoblotting e RT-PCR em tempo real, os animais foram sacrificados por deslocamento cervical nos diferentes tempos de sobrevida avaliados, e as áreas de interesse foram coletadas e processadas para análise. Observamos expressão de todos os mGluRs avaliados na neurópila e em pericários das camadas superficiais do CS e no NGL. Foi observado aumento significativo da expressão gênica de mGluR1 no lado experimental do CS em todos os tempos de sobrevida estudados. A sua expressão protéica mostrou-se aumentada apenas a partir do $15^{\circ}$ dia pós-lesão e a imunorreatividade apenas no $30^{\circ}$ dia. Para mGluR5, a expressão gênica e protéica no CS aumentou no $30^{\circ}$ dia e a imunorreatividade aumentou a partir do $7^{\circ}$ dia pós-lesão. Não se detectou alteração protéica para mGluR2/3 no CS, sendo que houve diminuição da expressão gênica para mGluR3 no $1^{\circ}$ e $7^{\circ}$ dias de sobrevida. Diferentemente para mGluR7, houve variação gênica já no $1^{\circ}$ e $7^{\circ}$ dias, e o aumento foi também observado na análise protéica que se manteve até o $15^{\circ}$ dia pós-lesão. Não houve variação de expressão protéica para os mGluRs no NGL nas sobrevidas avaliadas. No $\mathrm{TeO}$ foi observada imunorreatividade para mGluR1 na neurópila das camadas superficiais e em pericários de camadas profundas, enquanto para mGluR5 foi observada apenas marcação na neurópila das camadas superficiais. A expressão de mGluR2/3 
apareceu em forma de grumos nas camadas 5 e 6 . Para mGluR1 e mGluR5, houve aumento da imunorreatividade a partir do $1^{0}$ dia pós-lesão. As análises de immunoblotting confirmaram o aumento observado de mGluR1 e mGluR5 no TeO de pintos. Entretanto, houve diminuição da expressão de mGluR2/3 a partir do $7^{\circ}$ dia, como também alteração do seu padrão de marcação, que se apresentou contínuo e não mais em forma de grumos. A sua expressão protéica também se mostrou diminuída a partir do $15^{\circ}$ dia pós-lesão. Em relação a mGluR7, não encontramos imunorreatividade em pintos. Os resultados indicam que há uma modulação diferencial da expressão gênica e protéica dos mGluRs avaliados após a enucleação ocular. Os dados em geral foram semelhantes nas duas espécies estudadas, sugerindo uma conservação dos mecanismos desses subtipos de mGluRs em processos de lesão. Além disso, a modulação encontrada sugere que esses receptores podem exercer uma função importante na plasticidade neuronal decorrente de lesões no sistema visual adulto.

Palavra-chave: Receptores de glutamato. Receptores metabotrópicos. Sistema visual. Encucleação ocular. Plasticidade neuronal. 


\section{AbStract}

Matos, RJB. Expression of metabotropic glutamate receptors in the rat and chick visual system after ocular enucleation [PhD Thesis]. São Paulo: Instituto de Ciências Biomédicas da Universidade de São Paulo; 2000.

The metabotropic glutamate receptors (mGluRs) are involved in neuronal plasticity, brain disorders and neuroprotection. We studied here the expression of mGluRs in the visual system before and after retinal deafferentation. The areas analyzed were the superior colliculus (SC) and the lateral geniculate nucleus (LGN) of rats and the optic tectum $(\mathrm{TeO})$ of chicks. To evaluate the localization and expression of those receptors, we used standard immunoperoxidase, immunoblotting and real-time PCR protocols. Adult male Wistar rats and domestic chicks were anesthetized with ketamine and xylazine and submitted to unilateral eye enucleation. After different survival periods $(1,7,15$, and 30 days), the animals were deeply anesthetized, perfused with saline and $2 \%$ paraformaldehyde, and their brains were cryoprotected and cut on a sliding microtome. The sections were incubated with antibodies against mGluR1, mGluR5, mGluR2/3 and mGluR7, and reactions were detected with an enhanced avidin-peroxidase method. For immunoblotting and real-time PCR protocols, the animals were killed by cervical deslocation in several survival times and the tissues were coleted. We observed the expression of all mGluRs tested in neural processes of the superficial layers of the SC, LGN and in the TeO. The expression of mGluR1 and mGluR5 receptors in the SC showed an increase in 7, 15 and 30 day-survival periods tested, whereas no changes were seen for mGluR2/3 in the SC and all mGluRs in the LGN. For mGluR7, the protein expression increased after 1, 7 and 15 post-lesion days. Immunoblotting and real- time PCR analyses confirmed that some mGluRs are upregulated in the SC and that mGluR3 was decreased. In the $\mathrm{TeO}$, there were mGluR1 receptors in processes of superficial layers and in cell bodies of deep layers, whereas mGluR5 receptors were observed exclusively in superficial layers. For mGluR2/3, the expression appeared as blob-like structures in tectal layers 5 and 6 . The label changes for mGluR2/3 after enucleation, with decreases after 7, 15 and 30 days post-lesion. For both mGluR1 and mGluR5, there was an increase of the expression in the $\mathrm{TeO}$ for all survival periods analyzed. 
Immunoblotting analyses confirmed increases for mGluR1 and mGluR5 in 1, 15 and 30 survival post-lesion days; and decreases for mGluR2/3 in the $15^{\text {th }}$ and $30^{\text {th }}$ days. These results indicate that the expression of mGluR receptors is regulated by the glutamatergic retinal input, and add data on a possible role of these receptors in neuroplasticity in adult animals.

Key-words: Glutamate receptor. Metabotropic receptor. Visual system. Ocular enucleation. Neuroplasticity. 


\section{INTRODUÇÃO}

\subsection{Aspectos Gerals}

Desde a década de 50 do século passado, estudos eletrofisiológicos, farmacológicos e bioquímicos foram estabelecendo os mecanismos das ações excitatórias do aminoácido glutamato na transmissão sináptica no sistema nervoso central (SNC). No decorrer do período, a identificação farmacológica dos múltiplos receptores de glutamato ampliou a caracterização desse sistema de neurotransmissão (Watkins e Jane, 2006). Algumas pesquisas como as de Curtis et al. (1960) e Curtis e Watkins (1965) observaram algumas mudanças nas propriedades eletroquímicas e estruturais do canal iônico de uma célula neural, quando modificavam a interação da molécula de glutamato com um sítio de ligação do receptor. Os resultados desse e de outros estudos levaram a indícios dos distintos receptores de glutamato no SNC. Na década de 60, outras substâncias análogas ao aminoácido glutamato foram sintetizadas e suas diversas funções sinápticas foram sendo reconhecidas (Watkins e Jane, 2006).

Atualmente, o glutamato é reconhecidamente um importante mediador excitatório e seus receptores estão presentes na membrana plasmática de uma ampla variedade de neurônios e células gliais (Steinhauser e Gallo, 1996; Conti et al., 1999; Bergles et al., 2000). Além disso, esse neurotransmissor sinaliza eventos em tecidos e órgãos periféricos, bem como em células endócrinas (Moriyama et al., 2000). Um dado interessante na literatura indica uma longa história evolutiva dos receptores de glutamato, tendo sido observado que há sítios de reconhecimento deste em bactérias e em plantas com a função de modulação fótica (Lam et al., 1998).

Dentre os motivos pelos quais o glutamato e seus receptores (GluRs) têm sido alvos de muitos estudos está a sua importante participação em processos fisiológicos. Dentre eles, destacam-se o seu papel fundamental na transdução de sinais celulares, formação da rede neuronal durante o desenvolvimento e em eventos como memória, aprendizado, plasticidade sináptica (Mayer e Westbrook, 1987; Dingledine et al., 1988; Monaghan et al., 1989), dentre outros processos. Alguns estudos têm revelado os mecanismos intracelulares pelos quais o glutamato 
causa alterações na eficiência sináptica, transcrição gênica e morfologia neural (Mayer e Westbrook, 1987; Kind e Neumann, 2001; Chan et al., 2002).

Por outro lado, o glutamato também está envolvido em processos patofisiológicos, incluindo, dor, trauma, epilepsia e esquizofrenia, entre outros. De fato, tanto o glutamato como outros aminoácidos excitatórios em altas concentrações são tóxicos para o sistema nervoso. Exemplos de ativação excessiva dos GluRs são observados em situações como a isquemia, trauma cerebral e epilepsia, que podem conduzir à morte de neurônios. Além disso, a exacerbação da estimulação de GluRs pode ocasionar também processos de morte celular em distúrbios neurodegenerativos crônicos, como esclerose amiotrófica lateral, doença de Huntington, Parkinson e Alzheimer (Mayer e Westbrook, 1987; Dingledine et al., 1988; Monaghan et al., 1989; Meldrum et al., 1999; Meldrum, 2000; Lee et al., 2004). Vários pesquisadores demonstraram que a ativação excessiva dos receptores e aminoácidos excitatórios pode iniciar uma série de eventos bioquímicos intracelulares, resultando em uma lesão do SNC em desenvolvimento e em adultos (Olney et al., 1973; Schwarcz et al., 1984; Stewart et al., 1986; Choi, 1988; Mcdonald et al., 1988; Mcdonald, 1989; Rothman e Olney, 1995).

Com o advento da biologia molecular, os receptores de glutamato foram clonados e divididos em duas grandes famílias (Nakanishi, 1992; Hollmann e Heinemann, 1994): uma família de receptores que medeiam as respostas sinápticas rápidas por abertura e fechamento de canais iônicos específicos para cátions (ionotrópicos), e a outra, de receptores que produzem as respostas sinápticas mais lentas, associadas a mudanças bioquímicas e que são compostos por receptores acoplados a proteínas-G (metabotrópicos) (Nakanishi, 1992; Nakajima et al., 1993; Hollmann e Heinemann, 1994; Schoepp et al., 1999). Os receptores ionotrópicos de glutamato (iGluRs) são subdivididos em três grupos com base na seletividade aos agonistas de glutamato: ácido $\alpha$-amino-3-hidróxi-5-metil-4-isoxazolpropiônico (AMPA), cainato (KA) e N-metil-D-aspartato (NMDA) e medeiam a transmissão sináptica rápida (Hollmann e Heinemann, 1994; Hollmann et al., 1994; Schoepp, 2001). Entretanto, os receptores metabotrópicos de glutamato (mGluRs) influenciam uma variedade de segundos mensageiros que modulam a excitabilidade neuronal, plasticidade sináptica e neurodegeneração (Schoepp, 2001; Gerber et al., 2006). Os mGluRs são subdivididos em três grupos baseados nas propriedades farmacológicas e de acordo com a via de sinalização que eles ativam. São 
constituídos por 8 subtipos (mGluR1-8) que são altamente heterogêneos quanto aos mecanismos de transdução, distribuição e em sua seletividade a agonistas (Nakanishi, 1992; Ozawa et al., 1998; Kim et al., 2007).

Em estudos de localização destes receptores no SNC de ratos, mostrou-se que eles estão presentes em diversas estruturas do sistema nervoso como hipocampo, tálamo, substância negra, colículo superior, cerebelo e medula espinhal, dentre outras (Blackstone et al., 1992; Martin et al., 1992). Os GluRs estão também presentes em muitas outras estruturas como na retina (Silveira Dos Santos Bredariol e Hamassaki-Britto, 2001; Sosa e Gleason, 2004) e em muitas espécies de vertebrados e mesmo invertebrados (Pires et al., 2000; Batista, 2006).

\subsection{Receptores de Glutamato}

\subsubsection{RECEPTORES IONOTRÓPICOS}

O emprego de técnicas de biologia molecular possibilitou a clonagem e sequenciamento de diversas subunidades dos iGluRs: 4 para AMPA (GluR1-4) (Boulter et al., 1990; Keinanen et al., 1990; Sommer et al., 1990), 5 para cainato (GluR5-7, KA1-2) (Hollmann et al., 1989; Bettler et al., 1990; Egebjerg et al., 1991; Bettler et al., 1992; Hollmann et al., 1994; Bettler e Mulle, 1995) e 5 para NMDA (NR1, NR2A-2D) (Moriyoshi et al., 1991; Ikeda et al., 1992; Kutsuwada et al., 1992; Meguro et al., 1992; Monyer et al., 1992).

A partir da analogia com os receptores de acetilcolina e $\mathrm{GABA}_{\mathrm{A}}$, foi proposto inicialmente que os iGluRs tinham um largo domínio amino-terminal ( $\mathrm{N}$-terminal) extracelular, 4 segmentos transmembrânicos hidrofóbicos (TMI-TMIV) e uma porção carboxi-terminal (C-terminal) extracelular. Porém, este modelo convencional foi posteriormente revisado, em estudos de imuno-histoquímica e análises bioquímicas, que demonstraram que a porção C-terminal é intracelular e não extracelular como se acreditava (Petralia e Wenthold, 1992; Tingley et al., 1993). Hollmann e Heinemann (1994) fizeram uma série de experimentos na tentativa de determinar o modelo transmembrânico das subunidades de iGluRs. Esses autores demonstraram que os receptores de glutamato apresentam apenas três domínios transmembrânicos, que correspondem aos domínios TMI, TMIII e TMIV. O segmento M2 não chega a atravessar a membrana, retornando para a região intracelular. Além disso, a região 
entre o TMIII e TMIV, que anteriormente pensava-se ser intracelular, é extracelular, e a porção C-terminal é intracelular. Este novo modelo não é aplicado apenas aos receptores do tipo AMPA, mas também aos receptores do tipo cainato e NMDA (Kuryatov et al., 1994). Todos os três tipos são permeáveis a cátions, entretanto a permeabilidade ao $\mathrm{Na}^{+}$e $\mathrm{Ca}^{++}$varia de acordo com a família e composição da subunidade do receptor (Meldrum, 2000).

Os receptores AMPA participam da neurotransmissão rápida na maioria das sinapses no SNC. Esses receptores foram inicialmente nomeados como receptores de quisqualato, e posteriormente renomeados de receptores AMPA, quando foi descoberto que o quisqualato atuava também em mGluRs.

As quatro subunidades de receptores AMPA são similares no tamanho (aproximadamente 900 aminoácidos) e apresentam uma homologia na seqüência de aminoácidos de 68-73\% (Boulter et al., 1990; Seeburg, 1993; Bettler e Mulle, 1995). Os iGluRs do tipo AMPA parecem ser heteroligoméricos, sendo constituídos por 4 subunidades, em diferentes combinações das subunidades GluR1-4 (Mano e Teichberg, 1998; Rosenmund et al., 1998).

O outro grupo dos receptores ionotrópicos de glutamato, os receptores de NMDA, participam da neurotransmissão excitatória no SNC por diferentes caminhos dos realizados pelos GluRs do tipo AMPA. Os GluRs do tipo NMDA apresentam um bloqueio de $\mathrm{Mg}^{2+}$ voltagem-dependente (Mayer e Westbrook, 1987) e uma alta permeabilidade aos íons $\mathrm{Ca}^{2+}$ (Mayer et al., 1984).

O complexo canal do receptor de NMDA tem vários aspectos característicos. Somente os canais homoméricos formados pela subunidade NMDAR1 são funcionais quando ativados por glutamato, ibotenato, quisqualato e homocisteato; as outras subunidades, NMDAR2A-D, necessitam da presença da subunidade NMDAR1 para formar um receptor funcional (Nakanishi, 1992; Mori e Mishina, 1995). O canal deste receptor é altamente permeável ao $\mathrm{Ca}^{2+}$, bem como ao $\mathrm{Na}^{+}$e $\mathrm{K}^{+}$, e o aumento resultante do $\mathrm{Ca}^{2+}$ intracelular parece ser o responsável tanto pela plasticidade neuronal como pela toxicidade, nas quais esse receptor parece estar envolvido (Monaghan et al., 1989; Collingridge e Singer, 1990). Esse receptor pode ser diferenciado dos outros receptores de glutamato por sofrer ação de vários agonistas e pelas suas propriedades que incluem modulação de glicina, bloqueio do canal pelo $\mathrm{Mg}^{2+}$, ativação pela poliamina e inativação pelo $\mathrm{Zn}^{2+}$ (Monaghan et al., 1989). 
Embora o cainato seja um potente agonista do receptor AMPA, ele também ativa uma classe distinta de iGluRs, os receptores do tipo cainato. Com os estudos de ligantes radioativos, foi observado em GluR5-GluR7 um sítio ligante de cainato de baixa afinidade, enquanto em KA1-KA2 foi observado um sítio de alta afinidade (Seeburg, 1993; Hollmann e Heinemann, 1994; Bettler e Mulle, 1995).

A utilização de técnicas de hibridação "in situ" (Seeburg, 1993; Bahn et al., 1994) e imuno-histoquímica (Huntley et al., 1993; Siegel et al., 1995) demonstraram que os receptores de cainato estão diferencialmente distribuídos no sistema nervoso central. O mRNA de KA1 foi principalmente observado na região $C A 3$ e no giro denteado do hipocampo. O KA2 apresentou uma distribuição por todo o encéfalo, enquanto o mRNA de GluR5 foi expresso no córtex pirifome e cingulado, no subiculum, nos vários núcleos septais e nas células de Purkinje.

\subsubsection{ReCEPtores Metabotrópicos}

Todos os mGluRs são considerados proteínas grandes (854-1179 aminoácidos) e são ancorados à membrana celular por sete domínios transmembrânicos. Eles possuem um domínio extracelular $\mathrm{N}$-terminal hidrofílico de aproximadamente 600 aminoácidos, e um domínio citoplasmático C-terminal, no qual o comprimento pode variar de acordo com o subtipo, variando de 32 a 377 aminoácidos (Nakanishi, 1992; Hollmann e Heinemann, 1994; Pin e Duvoisin, 1995; Enz, 2007). A variabilidade de domínios intracelulares dos subtipos dos mGluRs aumenta ainda mais por seus "splicing" alternativos, portanto ampliando a variedade de acessos distintos ao domínio intracelular C-terminal (Enz, 2007).

Os 8 subtipos de mGluRs são classificados em 3 subgrupos com base na homologia da seqüência de aminoácidos e critérios funcionais: grupo I (mGluR1 e mGluR5), grupo II (mGluR2 e mGluR3) e grupo III (mGluR4, mGluR6-8) (Pin e Duvoisin, 1995; Kew e Kemp, 2005). Os membros do mesmo subgrupo apresentam homologia de $70 \%$ na seqüência dos aminoácidos, e a homologia entre os diferentes subgrupos é de cerca de $45 \%$. Essa classificação inclui também aspectos farmacológicos e mecanismos de transdução de sinais (Tabela 1).

Os receptores do grupo I, que inclui o mGluR1 e mGluR5 (variantes "splicing": mGluR1a-e, mGluR5a,b), são ativados fortemente por quisqualato e são acoplados a 
proteína Gq. A sua ativação estimula a hidrólise do fosfatidilinositol-bifosfato $\left(\mathrm{PIP}_{2}\right)$, gerando como segundos mensageiros o diacilglicerol (DAG) e inositol trifosfato. A via do inositol trifosfato $\left(\mathrm{IP}_{3}\right)$, por sua vez, libera $\circ \mathrm{Ca}^{2+}$ de estoques intracelulares, enquanto o DAG facilita a ativação de proteína quinase C (PKC) (Abe et al., 1992; Aramori e Nakanishi, 1992; Meldrum, 2000). Tanto o mGluR1 como o mGluR5 são ativados por 3,5-diidroxifenilglicina (DHPG) (Nicoletti et al., 2008). Os receptores do grupo II, mGluR2 e mGluR3, são acoplados a proteína Gi. A ativação desses receptores produz efeitos pleiotrópicos, incluindo a inibição da adenilato ciclase, inibição de canais de $\mathrm{Ca}^{2+}$ voltagem-dependentes e a ativação de canais de $\mathrm{K}^{+}$, inibindo assim a produção de AMPc (Tanabe et al., 1992; Nakajima et al., 1993; Okamoto et al., 1994; Duvoisin et al., 1995b; Conn e Pin, 1997; Meldrum, 2000). Ambos subtipos de receptores são potencialmente ativados por uma série de agonistas específicos, como o LY354740 e LY379268 (Nicoletti et al., 2008). Com efeitos intracelulares similares ao grupo II está o grupo III, que inclui os receptores mGluR4, mGluR6, mGluR7 e mGluR8. Eles são acoplados a proteína Gi/Go e são ativados por I-2-amino-4-phosphonobuanoate (L-APA) e pelo composto endógeno, Iserina-O-fosfato (Nicoletti et al., 2008) (Tabela 1).

Tabela 1. Subtipos de receptores metabotrópicos de glutamato e seus mecanismos de transdução e agonistas/antagonistas específicos.

\begin{tabular}{|l|c|c|c|}
\hline & GRUPO I & GRUPO II & GRUPO III \\
\hline \hline SUBTIPOS & mGluR1, mGluR5 & mGluR2, mGluR3 & $\begin{array}{c}\text { mGluR4, mGluR6, } \\
\text { mGluR7,mGluR8 }\end{array}$ \\
\hline PROTEÍNA G & Gq & Gi/o & Gi/o \\
\hline ACOPLADA & $\uparrow \mathrm{AP} 3$ & $\downarrow \mathrm{AMPc}$ & $\downarrow \mathrm{AMPc}$ \\
\hline EFETORES & $\downarrow \mathrm{Ca} 2+$ & $\uparrow \mathrm{Ka}+$ \\
ACOPLADOS & $\uparrow \mathrm{K}+$ & $\downarrow \mathrm{Ca2}+$ \\
\hline AGONISTAS & (S)-3,5-DHPG & LY354740 & L-AP4 \\
& t-ADA & LY379268 & \\
\hline & Quisqualato & & \\
\hline
\end{tabular}


Os mGluRs têm sido implicados em diferentes funções no SNC (Baskys, 1992; Schoepp e Conn, 1993; Dumas e Foster, 1997; Ozawa et al., 1998). Dentre elas, incluem-se a modulação das respostas excitatória e inibitória lentas (Glaum e Miller, 1992; Eaton et al., 1993), regulação de canais de cálcio (Chavis et al., 1994), de potássio (Netzeband et al., 1997) e canais não seletivos para cátions (Congar et al., 1997), inibição (Baskys e Malenka, 1991) e facilitação da liberação de transmissores (O'connor et al., 1995; Rodriguez-Moreno et al., 1998), indução da potenciação de longo prazo (Shigemoto et al., 1993a) e depressão de longo prazo (Linden e Connor, 1991; Conquet et al., 1994), a formação de vários tipos de memória (Aiba et al., 1994), regulação do tráfego de receptores ionotrópicos de glutamato (Lan et al., 2001; Snyder et al., 2001), regulação dos receptores NMDA na transmissão sináptica (Awad et al., 2000; Harney et al., 2006) e regulação do desenvolvimento neuronal (Pin e Duvoisin, 1995; Plenz e Kitai, 1998). Os mGlurRs estão envolvidos em várias doenças (Sansig et al., 2001), ansiedade e estresse (Linden et al., 2002; Swanson et al., 2005), retardo mental da fragilidade X (Bear et al., 2004), danos causados por hipóxia cerebral (Poli et al., 2003) e morte neuronal excitotóxica (Bruno et al., 2000). Na literatura alguns trabalhos demonstram essas funções, a exemplo da excitabilidade das sinapses do hipocampo regulada pela ativação dos mGluRs (Schoepp e Conn, 1993). Nas células de Purkinje cerebelares, a depressão de longo prazo (LTD) parece necessitar da cooperação funcional dos receptores AMPA/KA e mGluRs (Linden e Connor, 1991).

No encéfalo de ratos a ativação dos mGluRs contribui nas respostas tanto nos terminais pré-sinápticos como nos pós-sinápticos (Miles e Poncer, 1993; Gereau e Conn, 1995a; Rodriguez-Moreno et al., 1998). Os receptores do grupo I são preferencialmente localizados na membrana de neurônios pós-sinápticos, contribuem na regulação da plasticidade e estão envolvidos em processos neurodegenerativos, aprendizado, memória e controle motor (Conn e Pin, 1997). Por exemplo, os receptores mGluR1 presentes em células de Purkinje desempenham um papel chave no aprendizado motor e coordenação motora (Aiba et al., 1994; Conquet et al., 1994; Cirone e Salt, 2001). O receptor mGluR5 contribui para a indução da potenciação de longo prazo (LTP), associado à aprendizagem (Lu et al., 1997). Apesar de geralmente os mGluRs do grupo I serem expressos em membranas somatodendríticas (pós-sinápticas), esses receptores também podem modular a liberação de glutamato via mecanismos retrógrados, que podem envolver 
receptores canabinóides nas células de Purkinje (Kreitzer e Regehr, 2001; Brown et al., 2003), ou regulando a liberação, por estarem localizados diretamente em terminais axonais (Knopfel e Uusisaari, 2008). A expressão pré-sináptica do grupo I é observada nas fibras das aferências primárias no mesencéfalo, núcleo trigeminal caudal (Liang et al., 2005) e colículo superior (White et al., 2003), e no bulbo olfativo (Mutoh et al., 2005). Quando há excitação celular em neurônios pós-sinápticos, estudos recentes têm demonstrado que a ativação do grupo I pode produzir uma inibição da hiperpolarização pela condutância de cálcio dependente de canais de potássio (Fiorillo e Williams, 1998; White et al., 2003; Knopfel e Uusisaari, 2008). Em células piramidais do hipocampo em CA1, a ativação do grupo I diminui a atividade dos canais de $\mathrm{K}^{+}$, modulando assim a excitabilidade celular (Charpak et al., 1990). Além disso, a ativação desses receptores aumenta em muitos neurônios as respostas ao glutamato pela excitação dos receptores do tipo NMDA e/ou AMPA (Awad et al., 2000; Mannaioni et al., 2001). Já os receptores tipo mGluR5 parecem estar relacionados à sobrevivência celular, uma vez que o tratamento com antagonista desse receptor e enzimas de depleção de glutamato em culturas de células granulares do cerebelo em desenvolvimento promoveram a morte celular programada (Copani et al., 1998).

Os receptores do grupo II localizam-se principalmente em regiões présinápticas, regulando a liberação de glutamato negativamente pela ativação dos canais de $\mathrm{K}^{+}$(Conn e Pin, 1997; Capogna, 2004). O mGluR3 são encontrados também em terminais pós-sinápticos e em células gliais. Estudos têm demonstrado que esses receptores reduzem potenciais excitatórios pós-sinátpico após microinjeções de agonistas específicos no hipocampo (Anwyl, 1999). Outros estudos farmacológicos com agonistas LY354740 e LY379268 observaram a atividade de mGluR2 e mGluR3 no modelo de ansiedade, isquemia global e psicoses, apoiando a hipótese de que eles possam prevenir a excitabilidade neuronal por reduzir 0 glutamato na fenda sináptica (Schoepp e Conn, 1993; Schoepp et al., 1999). Além disso, esses receptores podem exercer um efeito neuroprotetor em doenças neurodegenerativas, nas quais ocorre excitotoxidade produzida por estimulação excessiva de NMDA (Bruno et al., 1995; Nicoletti et al., 1996). A presença de mGluR3 em astrócitos pode sugerir que o efeito neuroprotetor possa ser induzido pela produção de fatores neurotróficos (Bruno et al., 1998). 
Os receptores do grupo III localizam-se também em regiões pré-sinápticas (não exclusivamente), inibindo a liberação de glutamato ou GABA. A ativação desses receptores reduz a liberação de glutamato através da inibição pré-sináptica de canais de Ca2+ (Capogna, 2004). Koerner e Cotman (1981) observaram a inibição da excitação da via perfurante no hipocampo após aplicação de agonistas LAP4. A inibição da atividade neuronal foi observada também em fibras do trato olfativo e na medula (Thomsen, 1997). Em comparação com mGluR7, os outros subtipos desse grupo têm uma distribuição mais restrita no SNC, porém pesquisas com esses receptores ainda são incipientes (Schoepp, 2001). O mGluR4 é expresso mais nas células de Purkinje do cerebelo e na medula (Schoepp, 2001). Já mGluR6, é exclusivamente expresso em células da retina e desempenha um importante papel na processamento visual (Nakanishi, 1992; 1995; De Blasi et al., 2001). O subtipo mGluR8 é encontrado no cerebelo e no córtex cerebral e pouco é conhecido sobre a função que ele exerce nessas regiões (Duvoisin et al., 1995a). A localização présináptica de mGluR7 tem sido demonstrada nos terminais da via córtico-estriatal (Kosinski et al., 1999) e parece que o mGluR7 pode estar expresso em neurônios do estriado. Esses dados sugerem que o mGluR7 pode contribuir com a modulação do controle do movimento e possivelmente na etiologia de suas patologias (Schoepp, 2001). Esse receptor está presente no corpo celular dos neurônios dos gânglios e corno dorsal da medula (Ohishi et al., 1995a), como também está presente na amígdala envolvido no processo de memória aversiva e de medo (Masugi et al., 1999). Esses receptores estão também presentes em terminais pré e pós sinápticos na retina (Brandstatter et al., 1996).

A ativação de receptores de glutamato por seu neurotransmissor modula diversas sinapses em muitas áreas do encéfalo, por exemplo no hipocampo (Scanziani et al., 1997; Semyanov e Kullmann, 2000), locus coeruleus (Dube e Marshall, 2000), cerebelo (Mitchell e Silver, 2000), no colículo superior (Thompson et al., 2004) e no núcleo geniculado lateral (De Labra et al., 2005; Govindaiah e Cox, 2006) de ratos e no tecto óptico de aves (Tasca et al., 1999). A presença desses receptores em variados tipos celulares indica um importante papel na modulação sináptica, podendo sugerir em um âmbito geral uma função protetora de populações neuronais (Yao et al., 2005). 


\subsection{Estruturas Anatômicas do Sistema Visual de Ratos e Pintos}

O sistema glutamatérgico participa da organização funcional do sistema visual, que inclui muitos neurotransmissores presentes na sua circuitaria sináptica. $O$ sistema visual é composto por vias neurais complexas, que funcionam como uma extensa rede de processamento paralelo a diversas informações sensoriais recebidas. As vias visuais centrais são definidas como áreas que recebem projeções diretas da retina (Stone et al., 1979). Essa extensa rede contém a via retinogeniculo-cortical cujas células ganglionares enviam informações aos núcleos visuais específicos (Stone et al., 1979). Em mamíferos, as áreas do núcleo geniculado lateral, colículo superior, pré-tecto, tálamo lateral e córtex visual são estruturas também envolvidas no processamento visual (Parvanelas, 1989). Em ratos, o colículo superior é o maior alvo para axônios da retina e o refinamento das conexões retino-coliculares ocorre durante as primeiras semanas após o nascimento. $O$ colículo tem suas principais funções na integração vísuo-motora, orientação reflexa e facilitação do movimento ocular (Dean e Redgrave, 1984).

Em outras espécies, algumas funções do sistema visual são semelhantes aos dos mamíferos. No caso, de pintos, o tecto óptico, que é uma estrutura homóloga ao colículo superior em mamíferos, possui uma representação precisa da retina sobre a sua superfície, recebe suas maiores projeções aferentes do olho contralateral, sendo muito utilizado para estudos sobre desenvolvimento e integração de múltiplas modalidades sensoriais (Cowan, 1968; Vanegas, 1984), plasticidade (Knudsen, 1982; Gold e Knudsen, 1999) e conexões sinápticas (Hunt e Kunzle, 1976; Karten et al., 1997).

O sistema básico de processamento da informação visual em mamíferos parte dos fotorreceptores da retina rumo às células bipolares e daí para as células ganglionares. As células ganglionares emitem seus axônios via nervo óptico, quiasma óptico e trato óptico até estabelecer sinapses em estruturas do tronco encefálico e do diencéfalo, como o colículo superior e o núcleo geniculado lateral. No caso de aves, os contatos sinápticos são realizados em grande parte no tecto óptico e em áreas retinorrecipientes do tálamo. 


\subsubsection{Sistema Visual de Ratos}

\section{A Retina}

A retina é uma das estruturas do sistema nervoso mais estudadas em função de sua arquitetura organizada em camadas celulares e plexiformes e facilidade de acesso (Batista, 2006). A retina é composta de camadas compostas de epitélio pigmentar, uma camada contendo cones e bastonetes, outra de células bipolares, horizontais e amácrinas e outra camada de células ganglionares. Na retina, a formação da imagem ocorre em três estágios: a fototransdução, a transmissão dos sinais por sinapses na camada de células bipolares e a transmissão desses sinais para as células ganglionares, que enviam as informações para o SNC.

Os axônios das células ganglionares da retina formam as eferências retinianas, e determinam a natureza da informação que cada núcleo retinorrecipiente receberá. Suas projeções formam o nervo óptico, em seguida o quiasma óptico e tracto óptico. O nervo óptico no rato albino adulto contém cerca de 100.000 axônios e todos eles são mielinizados (Fukuda et al., 1982; Lam et al., 1982). Em ratos pigmentados esse número de fibras aumenta um pouco (Huges e Cox, 1977). Quase todas as células ganglionares se projetam para o colículo superior (Linden e Perry, 1983) e ramificações dessas fibras se projetam para o núcleo geniculado lateral, ambos para o lado contralateral. Apenas uma pequena minoria das fibras se projeta para ambos os tratos ópticos (Cunningham e Freeman, 1977; Cowey e Perry, 1979).

O glutamato é usado como neurotransmissor de vários tipos celulares da retina, incluindo fotorreceptores, células bipolares e ganglionares (Marc et al., 1990). Outros neurotransmissores, como o GABA e substância P (Caruso et al., 1990), também são encontrados em células ganglionares e em estruturas visuais como 0 núcleo geniculado lateral.

\section{O Núcleo Geniculado Lateral}

O núcleo geniculado lateral (NGL) é dividido em três estruturas conhecidas como o núcleo geniculado lateral dorsal (NGLd), o núcleo geniculado lateral ventral (NGLv) e o núcleo intergeniculado (IGL) (Figura 1). Os neurônios do NGL recebem sinapses excitatórias das células ganglionares da retina contralateral, do lado contra e ipsolateral do colículo superior (Perry, 1980; Pasquier e Villar, 1982), de outras 
aferências subcorticais, de aferências corticais oriundas principalmente da camada 6 dos córtices visuais primário e secundário e sinapses inibitórias de neurônios GABAérgicos do próprio NGL (Mason e Groos, 1981; Takahashi, 1985).

No NGL (Figura 1), a maior parte das projeções retinianas do olho contralateral faz sinapse com neurônios do NGLd, que está situado na parte dorsolateral do tálamo dorsal. Essa eferência do olho contralateral converge para todo o NGLd, exceto em áreas esparsas que recebem as projeções retino-geniculadas do lado ipsolateral (Hayhow et al., 1962; Giolli e Creel, 1974). As projeções ipsolaterais no núcleo geniculado de roedores são relativamente pequenas, considerando o volume da estrutura (Giolli e Creel, 1974). Ao contrário de outros mamíferos, o NGLd de ratos não é uma estrutura laminada como ocorre em primatas (Gilbert e Wiesel, 1979). Contudo, no NGLd de ratos existem diferenças das aferências retinianas ipsolaterais e contralaterais (Lund et al., 1974; Lund et al., 1976; Bunt et al., 1983). Quando há remoção do olho, as terminações axonais mais mediais do NGLd degeneram mais rapidamente que os terminais axonais localizados mais lateralmente, exibindo também mudanças no tamanho das fibras. A neurodegeneração neurofibrilar acontece mais rapidamente, neste caso, em axônios menores (Cunningham e Lund, 1971; Lund e Lund, 1976).

As informações processadas no tálamo são então retransmitidas ao córtex visual (Parvanelas, 1989). As aferências do NGLd dirigem-se para o córtex visual primário (Lashley, 1934) córtex visual secundário medial (Perry, 1980) e lateral (Ribak e Peters, 1975) e também para a formação reticular talâmica (Coleman e Clerici, 1980; Sefton et al., 1981). No córtex visual primário, as projeções do NGLd atingem as camadas 1, 3 e 6 e principalmente a camada 4 (Peters et al., 1976; Peters e Feldman, 1976). Todas as projeções eferentes do NGLd são ipsolaterais e são restritas ao córtex occipital (Parvanelas, 1989).

A outra estrutura, o NGLv (Figura 1), subjacente ao NGLd, constitui a parte ventral do tálamo dorsal (Jones e Yang, 1985). Entre o NGLd e o NGLv, encontra-se uma pequena lâmina chamada de IGL, que corresponde à terceira região do NGL (Perry e Cowey, 1979; Moore et al., 2000). Duas regiões distintas podem ser observadas claramente no NGLv, uma lateral, denominada de magnocelular (NGLVMC) e uma porção mais medial, a parvocelular (NGLvPC). Apenas a região magnocelular recebe uma significante aferência retiniana proveniente de ambos os olhos (Cajal, 1911; Hickey e Spear, 1976) e seus neurônios respondem a estímulos 
visuais (Sumitomo et al., 1979). A região medial do NGLVPC recebe projeções principalmente de núcleos talâmicos não visuais (Kolmac et al., 2000). Lesões feitas no NGLv resultam em uma grande diminuição da discriminação da intensidade luminosa (claro/escuro), mas não afetam o padrão de discriminação de localização (Legg, 1979). De uma maneira geral, as eferências do GLV projetam-se predominantemente para regiões visuais. As projeções do IGL projetam-se para o hipotálamo e também para algumas regiões visuais (incluindo 0 núcleo supraquiasmático) (Moore et al., 2000).

Em ratos, entre 20 e $50 \%$ das fibras que chegam no NGLd são provenientes da retina, enquanto no colículo superior mais de $90 \%$ das aferências são provenientes da retina (Sefton, 2004).

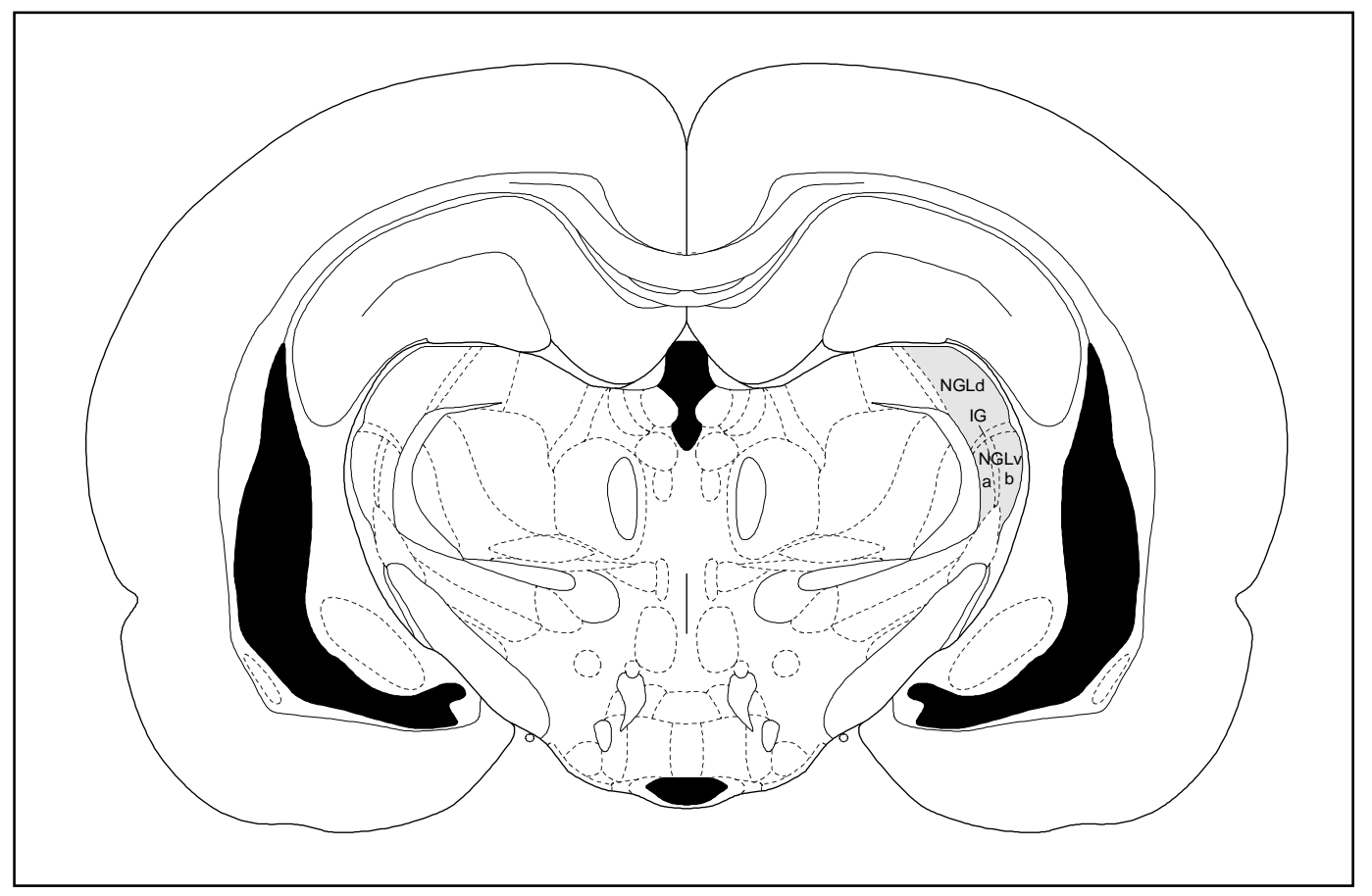

Figura 1. Esquema ilustrativo de corte coronal de encéfalo de ratos, ilustrando o núcleo geniculado dorsal (em cinza): NGLd; o núcleo geniculado ventral: NGLv e sua divisão em magnocelular (a) e parvocelular (b); IG: núcleo intergeniculado (Paxinos e Watson, 2005).

\section{O Colículo Superior}

Em ratos, as projeções retinianas dirigem-se em grande parte para o colículo superior (CS) (Figura 2) de mamíferos, que é homologo ao tecto óptico de outros vertebrados (Linden e Perry, 1983; Dreher et al., 1985). O colículo é uma estrutura subcortical que tem como principal função integrar respostas visuomotoras no reflexo de orientação e facilitação da mudança do ponto de fixação do olhar 
(Goodale e Murison, 1975; Dean e Redgrave, 1984) (Figura 2). O CS possui sete camadas alternando entre camadas de fibras e camadas celulares. As três primeiras camadas mais superficiais, conhecidas como zona marginal ou stratum zonale (ZO), camada cinzenta superficial ou stratum griseum superficiale (SuG) e óptica ou stratum opticum (Op) estão mais envolvidas com o processamento visual e recebem em grande proporção projeção da retina contralateral (Lam et al., 1982; Linden e Perry, 1983) e do córtex visual ipsolateral (Lund et al., 1976). Neurônios das camadas mais superficiais projetam-se para dois núcleos talâmicos, o NGLd e NGLv (Brauer et al., 1979), e para o complexo pulvinar lateral posterior, que novamente envia aferências ao córtex visual (Perry, 1980). As camadas intermediárias do CS (Figura 2) são conhecidas como camada cinzenta intermediária ou stratum griseum intermediale (InG) e camada branca intermediária ou stratum album intermediale (InWh). E as profundas são a cinzenta profunda ou stratum griseum profundum (DpG) e a branca profunda ou stratum álbum profundum (DpWh) (Lund e Lund, 1971a). Os neurônios das camadas intermediárias e profundas do CS recebem informações provenientes das camadas mais superficiais e integram as respostas visuais, auditivas e somatossensoriais, incluindo os estímulos nociceptivos (Sparks e Nelson, 1987). Em vários mamíferos, incluindo roedores noturnos como o rato, há uma projeção direta da retina que também termina na camada cinzenta intermediária (Beckstead e Frankfurter, 1983).

Com base na organização sináptica, as camadas superficiais do CS são similares em várias espécies de mamíferos (Lund, 1969; Lund e Lund, 1971b; a; Valverde, 1973). Tem-se descrito algumas categorias de perfil e especializações présinápticas no CS de ratos. Quase $60 \%$ do número total de botões sinápticos grandes que estão nas camadas mais superficiais contêm muitas vesículas e mitocôndrias próximas aos terminais neuronais. Certamente, esses terminais são originários da retina a julgar por mudanças ocorridas após a enucleação ocular. Os terminais que degeneram são encontrados em grande parte na camada cinzenta superficial, e em menor quantidade nas camadas marginal e óptica (Lund, 1969; Lund e Lund, 1971b). Outra categoria encontrada nessas camadas seriam os terminais pequenos de aparência escura, contendo poucas vesículas sinápticas. Eles podem pertencer a axônios locais ou de aferências reticulares e corticais. Após lesões no córtex visual, observa-se degeneração dos terminais na zona marginal e em todos os níveis da SGS e em particular na porção mais profunda (Lund, 1969; 1972). As sinapses 
retinianas e corticais são concentradas em diferentes regiões das camadas superficiais, mas sobrepõem-se extensivamente na SGS, ao contrário de primatas, onde há uma distribuição mais precisa (Lund, 1972).

Em roedores, o colículo superior está envolvido na localização espacial de um estímulo biológico significativo (Schneider, 1969). A posição do estímulo pode ser importante para diferenciar a modalidade sensorial que será utilizada. Diferentes tipos de estímulos podem influenciar os movimentos dos olhos, das orelhas e guiá-lo contra ou em direção a esse estímulo. Em suma, a função do colículo superior de ratos inclui orientação para os estímulos visuais (Goodale et al., 1978; Sahibzada et al., 1986), influência na navegação e orientação espacial dos movimentos (Cooper et al., 1998), na direção e velocidade dos movimentos dos olhos (Mchaffie e Stein, 1982; Okada, 1992), esquiva, defesa ou reações de escape (Olds e Olds, 1962; Redgrave e Dean, 1981; King, 1999), alvo sensoriomotor (Fendt et al., 1994; Meloni e Davis, 2000), influência sobre a exploração locomotora (Dean et al., 1982) incluindo aproximação e orientação do comportamento (Dean et al., 1986). Podem também estar envolvidos nos circuitos do controle de ritmo circadiano (Moore et al., 2000).

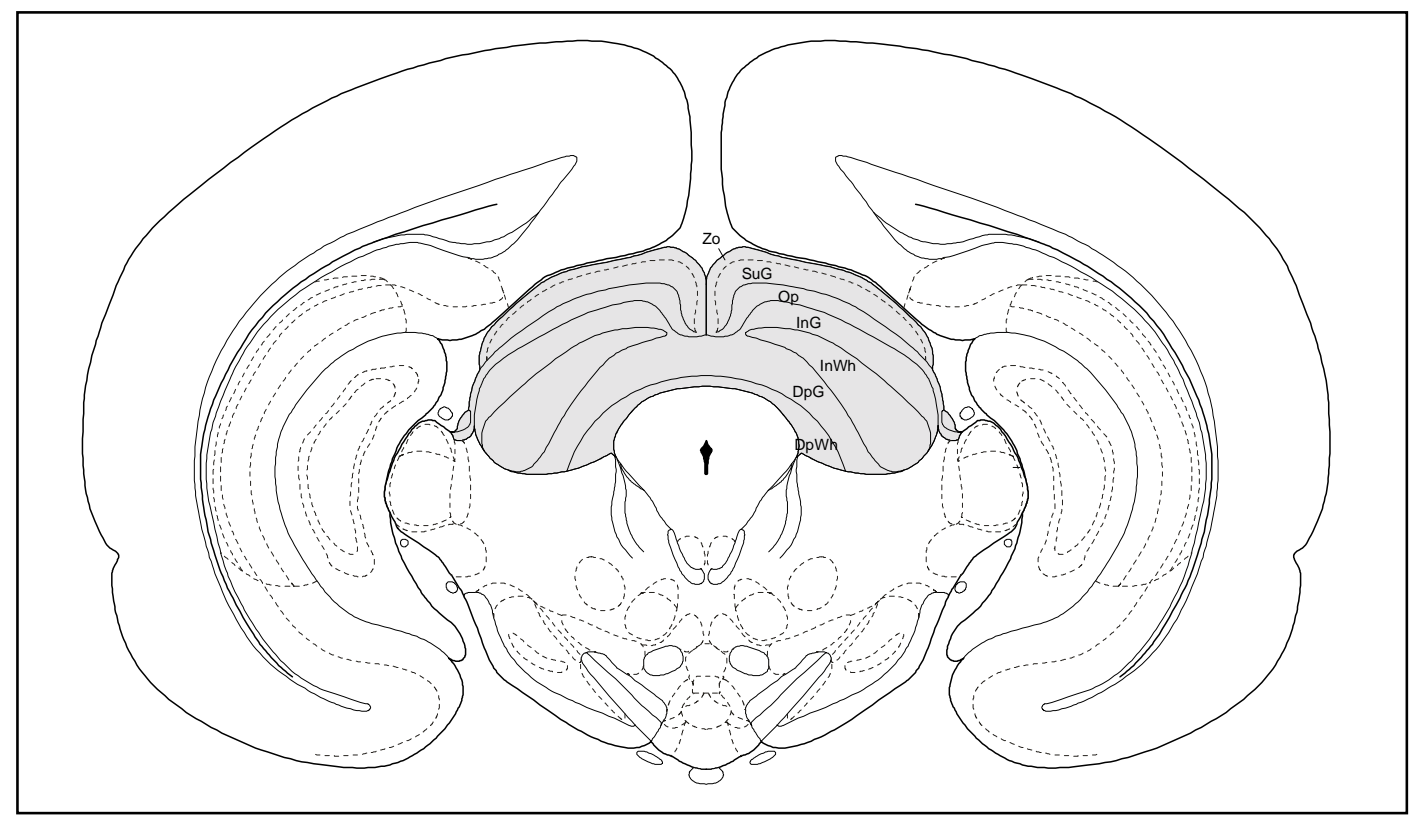

Figura 2. Esquema ilustrativo de corte coronal de encéfalo de ratos, ilustrando o colículo superior e suas camadas e o núcleo geniculado lateral. Em destaque encontram-se(cinza): Zo: zona marginal; SuG: camada cinzenta superficial; Op: camada óptica; InG: camada cinzenta intermediária; InWh: camada branca intermediária do colículo superior; profundas são a cinzenta profunda (DpG) e a branca profunda (DpWh) (Paxinos e Watson, 2005). 


\section{O Córtex Visual}

No encéfalo de ratos o córtex é localizado na superfície dorsal na região occipital e consiste em três distintas áreas pela morfologia. A área 17, que constitui o córtex visual primário, é a maior das três regiões. Essa área é margeada medialmente pela área 18 e lateralmente e caudalmente pela área 18a (Ribak e Peters, 1975; Zilles et al., 1980). Em estudos de eletrofisiologia, Montero et al. (1973) e Montero (1981) distinguem seis camadas visuotópicas em áreas do córtex occipital de ratos e de outras famílias de mamíferos. As seis camadas são conhecidas como: Camada I - camada molecular; Camada II - camada externa de células granulares; Camada III - camada externa de células piramidais; Camada IV - camada interna de células granulares; Camada V - camada interna de células piramidais; Camada VI - camada polimórfica ou multiforme (Batista, 2006).

O córtex é responsável pela função de análise de características visuais como forma, cores e localização da imagem e é composto por neurônios de projeção e por interneurônios. Os neurônios de projeção são representados por células piramidais que estão localizadas em todas as camadas exceto na camada I, e são excitatórios, contendo o neurotransmissor glutamato (Defelipe, 1997). Os interneurônios podem ser de dois tipos: as células estreladas com espinhos e células não piramidais lisas (Defelipe, 1997). As células estreladas com espinhos estão localizadas nas camadas intermediárias do córtex (especialmente na camada IV), e acredita-se que sejam excitatórias. Neurônios não piramidais lisos ou sem espinhos estão presentes em todas as camadas do córtex e são inibitórios, ou GABAérgicos (Defelipe, 1997).

A maioria dos neurônios do córtex visual (71 a 97\%) de ratos é representado por células piramidais (Peters e Kara, 1985; Werner et al., 1985). Diferenças entre as conexões do córtex visual servem como base para a divisão do córtex visual em diferentes partes (Zilles et al., 1985). Thurlow e Cooper (1988) mostraram que o córtex visual primário possui duas regiões que recebem aferências distintas.

\section{Córtex visual primário (área 17)}

O córtex visual primário de ratos também pode ser denominado como córtex estriatal, área V1, área 17 ou área Oc1. Na camada IV (principalmente) e VI há uma grande densidade de células e nas camadas II, III e V há uma baixa densidade de células. Cerca de $15 \%$ da população total de neurônios do córtex visual possui neurônios não-piramidais GABAérgicos (Meinecke e Peters, 1987). 
A porção lateral do córtex visual primário recebe aferências dos dois olhos, de estímulos originados da porção central do campo visual. A porção medial recebe aferências apenas do olho contralateral e responde a estímulos do campo visual periférico. A maior fonte dos estímulos visuais ao córtex é o GLD (Peters et al., 1985).

\section{Córtex visual secundário (área 18A- porção lateral)}

Diferentemente da área 17 , nessa região não há muita diferença do número de células entre as camadas. Nessa região, a camada II pode ser distinguida da III (Krieg, 1949; Miller e Vogt, 1984). Essa região recebe aferências tanto do córtex visual primário como do NGL. Como o núcleo lateral posterior recebe suas aferências do colículo superior, a região do córtex visual secundário recebe fibras das duas importantes eferências retinianas (Batista, 2006).

\section{Córtex visual secundário (área 18b- porção medial).}

Essa área recebe aferências basicamente do córtex visual primário (Olavarria e Montero, 1984; Thomas e Espinoza, 1987) e em menor quantidade, aferências do núcleo lateral posterior.

\subsubsection{Sistema Visual de Pintos}

\section{O Tecto Óptico}

O tecto óptico ( $\mathrm{TeO}$ ) é umas das estruturas importantes do sistema visual de aves, tem homologia ao colículo superior de mamíferos e localiza-se no mesencéfalo (Figura 3 e 4). O TeO atrai atenções por várias razões, sendo uma delas o fato de por ser uma estrutura laminada e facilmente reconhecida, como também possui uma representação precisa da retina sobre a sua superfície, oferecendo vantagens para o estudo da localização e sinalização de neurotransmissores no sistema nervoso central. Além disso, o TeO recebe suas maiores projeções aferentes do olho contralateral (Cowan, 1968; Vanegas, 1984).

O TeO é uma estrutura extensa e acessível tanto no ovo quanto no adulto e possui característica de ser bem definida, formando a porção externa do lobo óptico. Regiões internas do lobo óptico que estão abaixo do tecto incluem o pré-tecto, o 
complexo espiriforme, o núcleo do istmo e a formação reticular mesencefálica (Vanegas, 1984). Segundo a nomenclatura de Cajal (1911), o TeO possui 15 camadas facilmente identificadas em aves desde estágios embrionários avançados. Nas camadas já foram identificados mais de 20 tipos de neurônios (Lavail e Cowan, 1971), contendo receptores colinérgicos e glutamatérgicos, entre outros (Vanegas, 1984).

A origem das aferências do $\mathrm{TeO}$ são diversas, mas o predomínio é de projeções provenientes da retina contralateral cujos terminais atingem as camadas mais superficiais, enquanto as outras aferências atingem as camadas mais profundas.

Em aves, as projeções ipsolaterais da retina para o Teo são quase que inexistentes. Os terminais axonais da retina atingem as camadas 2, 3, 4, 5, 6 e 7 do $\mathrm{TeO}$ e nenhum estudo observou que este terminais atingem as camadas mais profundas. Muitas pesquisas têm tentado correlacionar as diferentes camadas no $\mathrm{TeO}$ e os diversos tipos de células ganglionares da retina que chegam nessas áreas, com intuito de encontrar o neurotransmissor utilizado por cada classe de célula ganglionar (Luksch, 2003).

A nomenclatura das camadas tectais foi baseada em estudos das disposições dos tipos celulares que são encontrados nessa estrutura. Baseado no padrão de arborização da célula, os neurônios podem ser classificados em radial, horizontal e multipolar. As células horizontais são encontradas nas camadas superficiais e as radiais e multipolares são localizadas em regiões mais profundas do TeO (Cajal, 1911; Lavail e Cowan, 1971).

As aferências do $\mathrm{TeO}$ são derivadas de uma extensa variedade de núcleos localizados no telencéfalo, diencéfalo e tronco cerebral. A maioria desses núcleos são localizados ipsolateralmente ao tecto e suas projeções terminam na lâmina tectal profunda e intermediária. Essas projeções ainda podem estar agrupadas dentro de categorias "visual" e "não-visual". Algumas projeções atingem também camadas mais superficiais como as do núcleo do instmo parvocelular (Ipc) e núcleo do istmo magnocelular (Imc). De uma maneira geral, as projeções eferentes do $\mathrm{TeO}$ são constituídas das projeções ascendentes que terminam no tálamo, das descendentes que terminam nos núcleos pontinos e formação reticular e as que terminam no núcleo do istmo (Cowan et al., 1968; Hunt e Kunzle, 1976). 
Análises bioquímicas têm demonstrado que há um grande número de neurotransmissores presentes do tecto como a glicina, GABA, acetilcolina e glutamato. As análises auto-radiográficas em cortes incubados com glutamato revelam que algumas camadas, as que continham terminais retino-tectais, apresentavam acúmulo de glutamato (Divac et al., 1977; Storm-Mathisen, 1977).

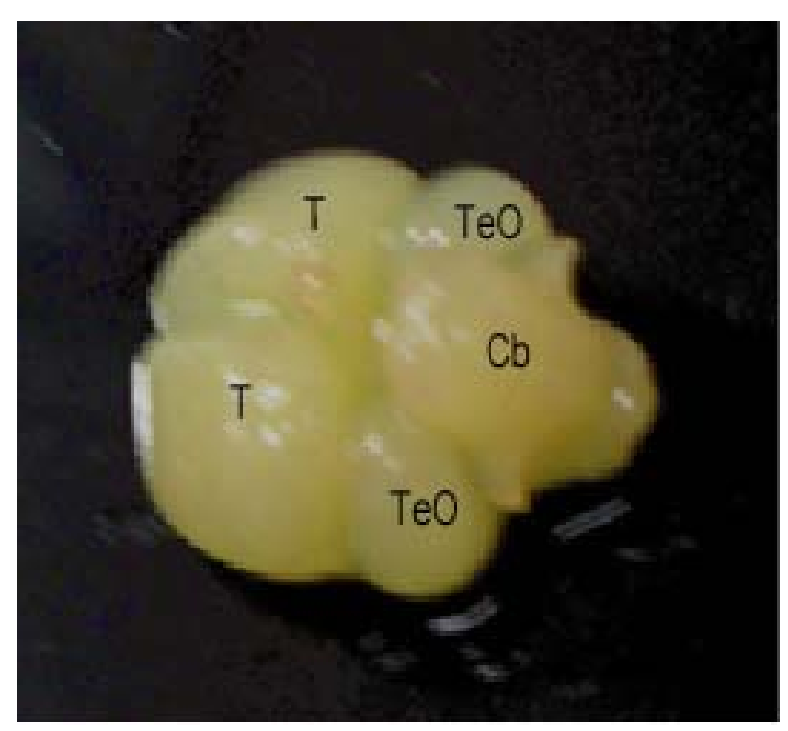

Figura 3. Imagem digital do encéfalo de pinto no $20^{\circ}$ dia de vida. $\mathrm{T}=$ telencéfalo; $\mathrm{TeO}=$ tecto óptico e $\mathrm{Cb}=$ cerebelo. Aumento: $2 \mathrm{x}$.

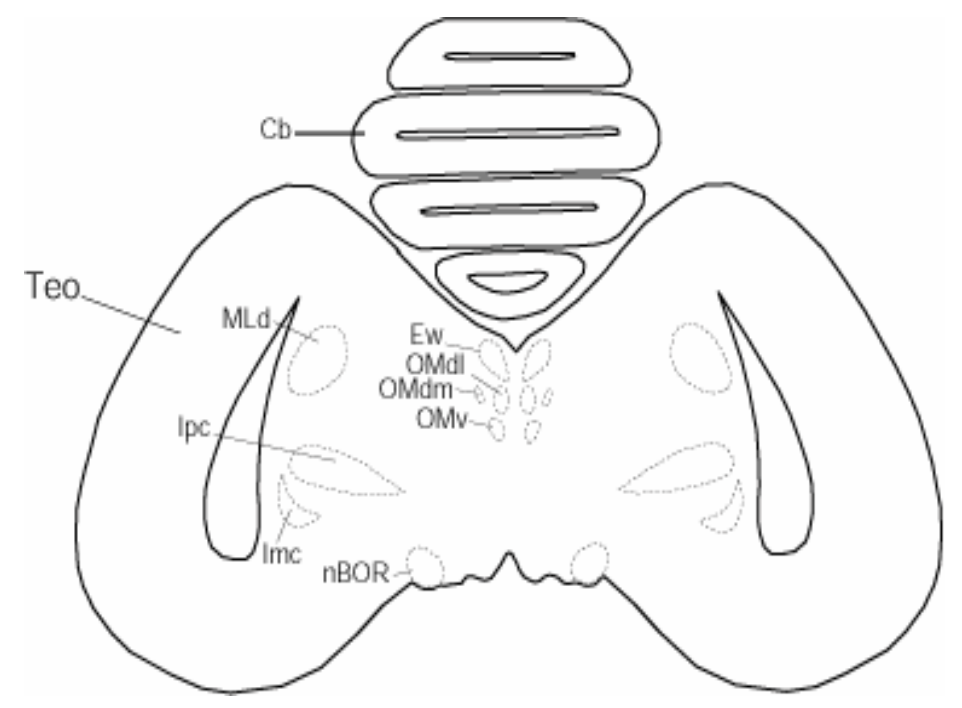

Figura 4. Esquema ilustrativo do $\mathrm{TeO}$ de pintos destacando as regiões-dorso-lateral e ventro-medial que foram analisadas com mais detalhes. As outras estruturas mencionadas são apenas ilustrativas. $\mathrm{Cb}$ : cerebelo; MLd: núcleo mesencefálico lateral, porção dorsal; Ipc: núcleo do istmo, porção parvocelular ; Imc: núcleo do istmo, porção magnocelular; nBOR: núcleo da raiz óptica basal; Ew núcleo de Edinger-Wesphal; OMdm, OMdl e OMv: porção dorsomedial, porção dorsolateral e porção ventral do complexo nuclear do nervo oculomotor (adaptado de Batista, 2002). 


\subsection{Os Receptores Metabotrópicos no sistema VISUAL}

O neurotransmissor mais utilizado nas sinapses retino-coliculares, genículocorticais (Li et al., 1996) e retino-tectais (Zhang e Schmidt, 1999) é o glutamato (Debski e Constantine-Paton, 1990; Li et al., 1996; Zhang e Schmidt, 1999). Os mGluRs podem estar localizados nos terminais pré e pós-sinápticos dos axônios dessas vias e promovem a auto-regulação da liberação de glutamato nas áreas retinorrecipientes, contribuindo com o processamento do sistema visual ( $\mathrm{Li}$ et al., 1996; Zhang e Schmidt, 1999; White et al., 2003).

Vários estudos em roedores (Sillito et al., 1990; Esguerra et al., 1992) e alguns em aves (Takacs et al., 1999; Tasca et al., 1999; Zhang e Schmidt, 1999) demonstram a participação do glutamato e seus receptores na transmissão sináptica em vias retinófugas (Roberts et al., 1991; Lo et al., 1998; Cirone e Salt, 2001). Alguns estudos utilizando imuno-histoquímica e hibridização in situ evidenciaram a distribuição dos vários subtipos dos receptores metabotrópicos no colículo superior (mGluR1, (Shigemoto et al., 1992; Hartveit et al., 1995); mGluR3, (Tanabe et al., 1993); mGluR4, (Hartveit et al., 1995; Ohishi et al., 1995a); mGluR5, (Shigemoto et al., 1993b; Romano et al., 1995); mGluR7, (Okamoto et al., 1994; Hartveit et al., 1995; Kinzie et al., 1995; Ohishi et al., 1995b)). O mGuR2 (Neki et al., 1996; Ohishi et al., 1998) e o mGluR8 (Saugstad et al., 1997) não parecem estar presentes no colículo superior ou em suas aferências. O mGluR6 é expresso exclusivamente na retina de ratos (Cirone e Salt, 2000). Nos estudos de Koulen et al. (1996) foi observada a presença de mGluR2 e mGluR4 na retina de rato em desenvolvimento. O receptor mGluR2 foi observado a partir de P5, enquanto mGluR4 já estava presente desde P1. Essa diferença no padrão de marcação sugere um papel distinto destes receptores na circuitaria sináptica da retina.

Cirone et al. (2002b) observaram que a imunorreatividade para mGluR1, mGluR5, mGluR4 no colículo superior é semelhante no rato, gato e furão. Em outros estudos mostraram que há uma expressão moderada dos mGluRs nas camadas superficiais do colículo superior, além de uma expressão intensa em outras áreas do encéfalo como o hipocampo (Shigemoto e Mizuno, 2000). Na retina de ratos, a imunorreatividade para mGluRs foi observada na camadas plexiformes interna (Peng et al., 1995) e externa (Koulen et al., 1996). A ativação de receptores do grupo I 
causa a redução excitatória da transmissão sináptica em camadas superficiais do CS. A aplicação in vivo de agonistas para esse subgrupo reduz as respostas visuais em todos os neurônios, em alguns o agonista DHPG produziu efeitos inibitórios e facilitatórios quando o agonista foi aplicado em diferentes correntes de injeção na mesma célula (Cirone et al., 2002a). O efeito facilitatório do DHPG pode ser visto em pequenos números de células em casos onde há aumento de liberação de glutamato (Rodriguez-Moreno et al., 1998) ou uma redução da transmissão GABAérgica (Gereau e Conn, 1995b). Por outro lado o efeito inibitório do DHPG sob as respostas visuais pode resultar em parte da inibição da liberação de glutamato nas sinapses retino-coliculares e córtico-coliculares, onde há mGluR1 (Martin et al., 1992; Shigemoto et al., 1992) e mGluR5 (Abe et al., 1992; Shigemoto et al., 1992; Shigemoto et al., 1993a; Romano et al., 1995). Entretanto, as ações sinápticas dos neurônios presentes em neurônios do colículo foi também notado em outros trabalhos (White et al., 2003). Cirone e Salt (2001) demonstraram que o grupo III medeia componentes de resposta de habituação nas camadas superficiais do CS.

Trabalhos com uso de antagonistas do grupo II aventam que a ativação desse grupo pode ser estimulada por ligantes endógenos durante o processamento visual. Esses receptores são comumente encontrados em axônios terminais da retina (Koulen et al., 1996), porém outros dados revelam a expressão de RNAm do mGluR2 e mGluR3 em camadas corticais (Ohishi et al., 1993b; a; Tanabe et al., 1993), indicando a presença do grupo II em aferências cortico-colicular. Trabalhos com imuno-histoquímica indicaram a expressão desse grupo em camadas superficiais do CS. Alguns receptores estão localizados em interneurônios e a possível ativação desses pode reduzir a transmissão GABAérgica (Calabresi et al., 1992) e promover a facilitação de respostas visuais. Também a modulação efetiva feita por meio do mGluR3 pode ser dada por sua presença em células da glia (Winder e Conn, 1996; Winder et al., 1996).

Cirone e Salt (2001) mostraram que ativação com agonista dos receptores do grupo III, L-AP4, aumentou a habituação e foi reduzida quando aplicou-se antagonista por iontoforese na camada superficial do CS. Há evidências que existem altos níveis de expressão de RNAm do mGluR4 em células ganglionares da retina que podem refletir repostas encontradas em seus terminais no CS (Hartveit et al., 1995). Outras pesquisas sugerem que o grupo III está presente em terminais córticocoliculares (Kinzie et al., 1995; Ohishi et al., 1995b) e em células intrínsecas das 
camadas superficiais do CS (Kinzie et al., 1995; Ohishi et al., 1995b). Hudtloff e Thomsen (1998) mostraram que existe um alto nível de ligações entre o agonista LAP4 e o grupo III no CS em comparação a outras regiões do cérebro. Há alguns estudos indicando que a ativação de receptores desse grupo deprime a transmissão sináptica pela redução de liberação de glutamato. A aplicação por iontoforese de agonistas e antagonistas no CS desse grupo tem demonstrado a sua modulação no processamento visual. Entretanto, dados tem evidenciado que os mGluRs do grupo III podem ser ativados quando há alta concentração e há uma estimulação repetitiva, ou seja, quando há uma grande concentração de glutamato na fenda sináptica (Cirone e Salt, 2000).

A ativação dos mGluRs também tem sido descrita em células de retransmissão do NGL. O uso de agonistas como o ácido trans-(1S, 3R)-1-amino-1, 3-ciclopentano-dicarboxílico produz despolarização da membrana que inativa ondas lentas de $\mathrm{Ca} 2+$, causando a ocorrência de disparos tônicos no neurônio. Um dos mecanismos que envolvem os efeitos excitatórios, quando há ativação dos mGluRs no NGL, parecem ser iniciados pelos receptores ligados à hidrólise do fosfatidilinositol presentes nas vias córtico-geniculadas. Os receptores envolvidos neste caso seriam o mGluR1a (um variante splicing do mGluR1) e mGluR5 (1996). Resultados de Govindaiah e Cox (2006) sugerem a ação dos mGluRs em múltiplos sítios do NGL, resultando em uma ação distinta em interneurônios e subseqüente influência inibitória no complexo talâmico. De uma maneira geral, a integração da atividade excitatória em neurônios talâmicos pode ser influenciada por uma atividade focal ou difundida dos neurônios. Eles sustentam a idéia de que há influência inibitória focal em neurônios de retransmissão do tálamo e a ativação dos interneurônios via mGluR5. Além do mais, a regulação distal da excitação córticotalâmica pode ser influenciada por neurônios do núcleo retino-talâmico mediado por mGluR2/3. Portanto, as múltiplas vias e mecanismos indicam que o glutamato via a ativação de mGluRs podem mediar significantemente a integração sináptica e modular informações em circuitos no NGL (Govindaiah e Cox, 2006).

Já no tecto óptico de pintos, estudos incipientes mostram a participação dos mGluRs no encéfalo de pintos, principalmente em regiões do cerebelo (Takacs et al., 1999). Um relato na literatura evidencia no TeO a expressão de mGluRs ligados a adenilato ciclase, após o uso de agonistas (L-AP3) para esses receptores, quando observaram inibição de adenosina induzida pelo acúmulo de AMPc em cortes do 
TeO (Tasca et al., 1999). Na retina de pintos já foram encontrados os vários grupos dos mGluRs; estudos de Hoffpauir e Gleason (2002) indicaram que a ativação do mGluR5 aumenta correntes pós-sinápticas em culturas de células amácrinas GABAérgicas de pinto.

Diferentes grupos de mGluRs tem uma variedade de efeitos complexos e de distintas modulações em alguns tipos de estímulos visuais. Isso pode evocar uma ampla variedade de respostas fisiológicas, envolvendo outros sistemas de neurotransmissão que resultam na modulação de respostas comportamentais em eventos sensoriais (Cirone et al., 2002a). Além disso, esses vários receptores podem promover modulações distintas em processos patológicos.

\subsection{Receptores Metabotrópicos de Glutamato e Plasticidade NEURONAL}

Os modelos animais e humanos de lesões químicas ou mecânicas no encéfalo ou na medula espinhal, traumas, isquemias já estão bem estabelecidos (Chong et al., 2003; Lea e Faden, 2003). Há vários relatos sobre a distribuição dos mGluRs e há evidências funcionais da participação em eventos plásticos no SNC. A relação entre o sistema glutamatérgico e a plasticidade neuronal foram corroboradas nos fenômenos já bem conhecidos de potenciação em longo prazo (LTP, do inglês long-term potentiation) e depressão em longo prazo (LTD, do inglês long-term depression) (Ito, 1989; Siegelbaum e Kandel, 1991). Em linhas gerais, na LTP a ativação dos receptores de glutamato em neurônios pós-sinápticos ativa vias de sinalização intracelular; subseqüentemente, ocorrerá uma intensa produção gênica e ativação de outros moduladores que, por sua vez, agirão em neurônios présinápticos, liberando assim mais neurotransmissores cuja conseqüência é uma maior eficiência sináptica. Nesses processos há intensa participação de receptores do tipo NMDA, AMPA e dos mGluRs. O mecanismo que envolve o LTP em neurônios da região do CA1 do hipocampo a LTD nas fibras paralelas dos neurônios de Purkinje no cerebelo tem sido extensivamente estudado, por serem estes mecanismos envolvidos com memória e aprendizado (Pin e Duvoisin, 1995) . Estimulações com freqüências altas nas fibras colaterais de Schaffer, ou a ativação concomitante dessa via neuronal com a despolarização de neurônios piramidais 
levam a ativação dos receptores NMDA e conseqüentemente despolarização póssináptica. Essa ativação é acompanhada pela remoção do íon $\mathrm{Mg}^{2+}$ associado a este canal. $\mathrm{O}$ influxo de $\mathrm{Ca}^{2+}$, promovido pela abertura dos canais de NMDA, ativa enzimas sensíveis a $\mathrm{Ca}^{2+}$, que potencializa a eficiência sináptica, provocando mudanças morfofuncionais nos neurônios pré e pós-sinápticos. Os mGluRs do grupo I (Naie et al., 2007), acoplados à fosfolipase $C$ aumenta a atividade do receptor NMDA, despolariza neurônios e favorece ainda mais a LTP (Siegelbaum e Kandel, 1991; Pin e Duvoisin, 1995). Os do grupo III estão envolvidos essencialmente na LTD no giro denteado do hipocampo; antagonistas para este subtipo impedem a LTD , variando entre $2 \mathrm{~h}$ a 2 dias (Klausnitzer et al., 2004; Altinbilek e ManahanVaughan, 2007).

Em contrapartida, as mudanças da atividade sináptica nas conexões neuronais, que são consideradas críticas em muitas funções do encéfalo, variam desde a plasticidade sináptica durante o desenvolvimento, na formação de memória, como também em aspectos fisiopatológicos na recuperação da função após um trauma e neurodegeneração. A plasticidade sináptica pode resultar em alterações nos componentes da sinapse, mediar mudanças na excitabilidade dendrítica e axonal e até mesmo alterar a expressão gênica em neurônios pré e pós-sinápticos. Contudo, a plasticidade sináptica pode interferir ainda nas interações neurônio-glia ou alterações vascular-neuronal (Lee, 2006). É fato que no SNC há habilidade dos neurônios em alterar o número, a sensibilidade dos neurotransmissores e dos seus receptores mediante mudanças no estado funcional da célula. Os componentes da sinapse, tais como os receptores de membrana, apresentam sítios de reconhecimento pelos quais sinais extracelulares podem ser traduzidos e amplificados em sinais biológicos intracelulares (Chalmers e Mcculloch, 1991a; b). Ajustes nos receptores podem ser um dos mecanismos pelos quais a atividade neuronal pode ser controlada e restabelecer as funções das áreas afetadas (Chang et al., 1980; Mantyh e Hunt, 1986). Além disso, pode haver também a participação da glia nesses processos, uma vez que há presença de receptores de glutamato $\mathrm{e}$ outros sistemas de neurotransmissão. A gliose reativa parece ter duas principais funções dentre as inúmeras desconhecidas, dentre elas a de isolar e de ocupar o local lesionado, permitindo assim o crescimento e o favorecimento das sinapses (Lenz et al., 1997). A imunorreatividade para GFAP tem sido utilzada como 
instrumento de localização da reorganização morfológica no modelo de enucleação (Hailer et al., 2001; Petzold et al., 2003).

Por muitos anos, os modelos de axotomia, levando a privação de neurotransmissores em diferentes sistemas foram alvos de vários estudos em ratos (Al-Abdulla et al., 1998; Ginsberg e Martin, 2002; Chong et al., 2003; Lea e Faden, 2003), camundongos (Torvik e Skjorten, 1971; Prusky et al., 2006) e em pintos (Lieberman, 1971; O'connor e Wyttenbach, 1974; Chu-Wang e Oppenheim, 1978; Pires et al., 2000; Luksch e Poll, 2002). Diversos fatores influenciam a progressão da lesão neuronal provocado pela axotomia e a probabilidade subseqüente de morte ou sobrevivência neuronal dependerá da idade do animal, o local do trauma e o tipo de lesão (Lieberman, 1971; Fry e Cowan, 1972; Martin et al., 1998). Além do mais, dependendo do tipo e extensão da lesão, pode haver uma liberação excessiva de fatores neurotóxicos, como também, ativar fatores como lipases, proteases, radicais livres, aminoácidos excitatórios, incluindo o glutamato, como outros neuromediadores. Esses fatores e os neuromediadores, por sua vez, medeiam vias intracelulares que podem ativar processos como apoptose ou necrose (Lea e Faden, 2003). Pode haver ainda perda da homeostase iônica e indução de respostas inflamatórias e imunológicas, entre outros processos. Cada vez mais estudos in vitro e in vivo mostram que a liberação excessiva de glutamato e subseqüente ativação dos seus receptores levaria a uma aumento na excitabilidade neuronal, ocasionando conseqüentemente a ativação de proteases e fosfatases, que ativam vias intrínsecas das caspases (Eldadah e Faden, 2000; Lea e Faden, 2003).

No sistema nervoso imaturo a axotomia em neurônios, dependendo do tipo, promove freqüentemente morte celular, entretanto no sistema nervoso adulto os neurônios provavelmente podem recuperar sua função (Lieberman, 1971; Martin et al., 1998). Por exemplo, a transecção neonatal do VII nervo cranial ou do nervo isquiático em roedores causa perda neuronal no núcleo facial. Em contraste, lesões similares nos adultos não produzem nenhuma perda nos neurônios motores (Prestige e Willshaw, 1975; Decker, 1978; Martin et al., 1998). A axotomia em neurônios motores no SNC imaturo pode induzir degeneração, baseando-se em evidências morfológicas no encéfalo de camundongos (Romanes, 1946) e pintos (O'connor e Wyttenbach, 1974; Chu-Wang e Oppenheim, 1978).Os receptores de glutamato podem participar de mecanismos excitotóxicos nesses modelos, provocando morte neuronal após axotomia em neonatos, pois a suscetibilidade à 
toxicidade provocada pela ativação dos receptores de NMDA ou não-NMDA nos neurônios motores da medula é maior nesse período (Greensmith et al., 1994). O bloqueio de receptores NMDA (Mentis et al., 1993) ou não-NMDA (Iwasaki et al., 1995) podem preservar os neurônios motores na medula de animais neonatos após axotomia (Martin et al., 1998). Outra relação entre a ativação de receptores de glutamato e a indução de apoptose e necrose no encéfalo de ratos adultos foi demonstrada nos estudos de Portera-Cailliau et al. (1997), através da aplicação de agonista de NMDA e cainato. Resultados semelhantes foram observados em ratos neonatos (Van Lookeren Campagne et al., 1995a; Van Lookeren Campagne et al., 1995b; Portera-Cailliau et al., 1997). Bloqueadores do receptor de NMDA impedem a apoptose das células ganglionares da retina (Bunch e Fawcett, 1993). Além do mais, alterações, como lesões indiretas e/ou diretas com ácido caínico no corpo estriado promovem alterações na substância P (Chang et al., 1980; Mantyh e Hunt, 1986) ou em receptores GABA (Chang et al., 1980). Todas observações demonstram que neurônios podem sobreviver a lesões em diferentes áreas do encéfalo e os mecanismos que envolvem essas interações são complexas.

Estudos in vivo e in vitro com utilização de agonistas específicos para mGluRs suportam a hipótese do papel destes receptores na neuroproteção. As pesquisas incluíram lesões no sistema nervoso como isquemia (Bond et al., 1998; Bond et al., 2000), lesões celulares in vitro induzindo trauma (Faden et al., 1997; Allen et al., 1999), lesões no estriado provocado por ativação de NMDA (Gasparini et al., 1999), toxicidade por glutamato (Buisson e Choi, 1995; Lafon-Cazal et al., 1999) ou óxido nítrico (Maiese et al., 1995; Maiese et al., 1996). Alguns mecanismos de neuroproteção mediado por estimulação dos mGluRs têm sido propostos, como a via de inibição direta da transmissão excitatória (Bonci et al., 1997) ou por inibir a atividade nos receptores NMDA (Lafon-Cazal et al., 1999). Essas investigações têm identificado a capacidade dos mGluRs de regular vias intracelulares específicas e alvos moleculares que podem determinar o destino da célula (Chong et al., 2003). As vias incluem a indução de apoptose, atividade de proteínas quinases, pH intracelular, atividade de endonucleases e geração de cisteínas (Maiese et al., 2005).

Além da busca em descobrir qual o papel dos mGluRs no SNC, a sua distribuição no sistema nervoso em geral também tem sido estudada extensivamente em roedores. Entretanto, ainda há raros trabalhos na literatura demonstrando a 
avaliação funcional da alteração de receptores metabotrópicos de glutamato após a enucleação ocular e suas implicações no processamento de informações no sistema visual de ratos adultos e pintos em um modelo polissináptico. 


\section{OBJetivos}

As várias evidências na literatura sobre a ativação dos receptores metabotrópicos de glutamato em processos fisiológicos, especificamente no sistema visual de vertebrados, sugerem uma importante função na modulação sináptica. Outros dados demonstram a sua participação em processos patológicos. As possíveis lesões em um sistema polissináptico como, no caso do sistema visual primário, podem promover mudanças morfofuncionais e esses receptores podem participar da plasticidade neuronal. Sabe-se ainda que as projeções retinianas utilizam o glutamato como neurotransmissor.

Diante disso, temos como objetivos:

\section{Geral:}

- Avaliar a expressão dos receptores metabotrópicos de glutamato após enucleação ocular em áreas visuais primárias, como o colículo superior e núcleo geniculado lateral de ratos e tecto óptico de pintos.

\section{Específicos:}

- Observar se há morte celular por apoptose após enucleação ocular;

- Avaliar a degeneração de fibras neuronais após enucleação ocular;

- Analisar se há aumento de gliose reativa após enucleação ocular;

- Avaliar a expressão gênica dos receptores metabotrópicos de glutamato após enucleação ocular;

- Quantificar a expressão protéica dos receptores metabotrópicos de glutamato após enucleação ocular;

- Avaliar a distribuição de terminais axonais após enucleação ocular. 


\section{MATERIAL E MÉTODOS}

\subsection{ANIMAIS E PROCEDIMENTOS GERAIS}

Foram utilizados ratos (Wistar) e pintos (Gallus gallus), com peso corporal, respectivamente, variando entre $200-320 \mathrm{~g}$ e 100-120g, fornecidos pelo Biotério do Instituto de Ciências Biomédicas da USP. Os animais foram mantidos em gaiolas em uma sala apropriada sob condições de umidade e temperatura controladas, com água e comida ad libitum e período de claro/escuro de 12/12 h. Todos os procedimentos foram realizados de acordo com o protocolo gravado pelo Colégio Brasileiro de Experimentação Animal (COBEA) e pela Comissão de Ética em Experimentação Animal (CEEA) (protocolo № 072/2005).

\subsubsection{ENUCLEAÇÃO OCULAR}

Para procedimentos cirúrgicos, os animais foram anestesiados com quetamina na dose de $5 \mathrm{mg} / 100 \mathrm{~g}$ de peso e xilazina na dose de $1 \mathrm{mg} / 100 \mathrm{~g}$ de peso por via intramuscular. Após aplicação de lidocaína na região peri-orbital e intraorbital no globo ocular direito no animal anestesiado, realizamos a enucleação daquele olho. Uma fração de esponja de gelatina absorvível (Gelfoam, Upjohn), que contém propriedades coagulantes e retém eventuais sangramentos, foi colocada na fossa ocular. Após esses procedimentos, as pálpebras foram suturadas com fio cirúrgico e os animais foram colocados novamente em suas respectivas gaiolas. Após esses procedimentos, as pálpebras foram suturadas com fio cirúrgico e os animais foram levados de volta as suas gaiolas. Dependendo do experimento a ser realizado, após tempos de sobrevida variados, os animais foram anestesiados profundamente e perfundidos com fixador, ou sacrificados rapidamente por deslocamento cervical e/ou decapitação. Cabe mencionar que foram utilizados 5 animais para cada tempo de sobrevida.

O lado ipsolateral do encéfalo foi usado como controle, já que as vias visuais são quase completamente cruzadas em roedores e aves. 
De acordo com os tempos de sobrevidas escolhidos, constituíram-se os grupos experimentais: 1, 7, 15 e 30 dias pós-lesão. No caso da análise de fragmentação do DNA, observamos também 1 e 3 horas e o 60 dia pós-lesão.

\subsection{DETECÇÃO DAS CÉLULAS COM FRAGMENTAÇÃO DE DNA}

Para avaliarmos se houve morte celular por apoptose após enucleação ocular nos vários tempos de sobrevidas estudados, utilizamos um dos métodos de detecção de células com fragmentação de DNA, TUNEL (do inglês, terminal deoxynucleitidyl transferase dUTP nick end labeling; (Gavrieli et al., 1992), utilizando-se "In situ cell death detection kit, Fluorescein" (Indianapolis, IN, USA).

O procedimento foi realizado após tempos de sobrevidas de 1 e 3 horas e 1 , $7,15,30$ e 60 dias. Os ratos e/ou pintos enucleados foram anestesiados e submetidos à perfusão transcardíaca com salina tamponada e paraformaldeído (PFA) a 4\% em tampão fosfato $0,1 \mathrm{M}$ (PB, pH 7,4). Os encéfalos foram retirados da caixa craniana e mantidos por um período de 30 minutos de pós-fixação e logo após foram transferidos para uma solução de sacarose a 30\% em PB para crioproteção por um período de $48 \mathrm{~h}$. Os encéfalos foram cortados no plano coronal em uma espessura de $30 \mu \mathrm{m}$ em um micrótomo deslizante de congelamento. Os cortes foram montados em lâminas gelatinizadas e deixados por aproximadamente $24 \mathrm{~h}$ em uma placa de aquecimento a $37^{\circ} \mathrm{C}$ para melhor adesão dos cortes nas lâminas. Em seguida, foram então submetidos ao método do TUNEL; utilizamos três cortes de encéfalos de ratos e de pintos para cada tempo de sobrevida. Cabe mencionar que utilizamos 2 animais para cada sobrevida. Logo em seguida, montamos os cortes em lâminas gelatinizadas, colocadas a seguir em placa quente por 12h. Após esse período, incubamos as lâminas em solução permeabilizante, contendo $0,1 \%$ de Triton-X 100 e 0,1\% de citrato de sódio em PBS (0,05M) por 2 minutos em gelo. Depois da incubação, lavamos as lâminas 2 vezes por 5 minutos em PBS $(0,1 \mathrm{M})$. No passo seguinte, preparamos a solução contendo a enzima e o nucleotídeo do kit. Incubamos então as lâminas por 60 minutos a 37ํㅡ com a enzima transferase (TdT) e os nucleotídeos marcados com fluoresceína, que são incorporados aos terminais da molécula de DNA fragmentado. A proporção utilizada da enzima e nucleotídeo foi de 1:6. Logo em seguida, lavamos o material 2 vezes por 5 minutos em PBS $(0,1 \mathrm{M})$. 
Após as lavagens, as lâminas foram cobertas com lamínulas, usando Vectashield (Vector Labs, Burlingame, CA, USA), e vedadas com esmalte. Utilizamos como controle negativo do experimento a omissão da enzima, e como controle positivo uma lâmina contendo cortes de retina de camundongo que foi submetida a neurodegeneração por luz (Belmonte et al., 2006). Os cortes foram analisados ao microscópio de fluorescência.

\subsection{DETECÇÃO DE DEGENERAÇÃO DE FIBRAS NEURONAIS}

Utilizamos o método de Fluoro-Jade B, um modelo de fluorocromo, que pode detectar degeneração neuronal. Há uma alta afinidade do traçador com processos neuronais, incluindo dendritos distais, axônios e terminais (Schmued e Hopkins, 2000). O método é bastante utilizado na detecção da degeneração de áreas encefálicas que foram submetidas a lesões com ácido caínico (Olney et al., 1973; Chang et al., 2007; Riljak et al., 2007).

Utilizamos esse método para detectar neurodegeneração no CS, NGL e TeO no $1^{\circ}, 7^{\circ}, 15^{\circ}$ e $30^{\circ}$ dias pós-lesão em cortes de encéfalos de ratos e pintos. Utilizamos dois animais para cada tempo de sobrevida. Para isso utilizamos seções de cortes com espessura de $30 \mu \mathrm{m}$, que foram montados em lâminas gelatinizadas e deixadas por aproximadamente $24 \mathrm{~h}$ em uma placa de aquecimento. As lâminas foram então colocadas em seqüência de soluções: álcool a $80 \%$, contendo $1 \%$ de $\mathrm{NaOH}$ por 5 minutos, em seguida, em álcool a $70 \%$ por 2 minutos e em água destilada por 2 minutos. Após esse processo de reidratação os cortes foram incubados em uma solução de $0,06 \%$ de permanganato de potássio por 10 minutos, sob agitação. Após esse processo, as lâminas foram lavadas com água destilada por 2 minutos e incubadas em solução de Fluoro-Jade B (Chemicon) e ácido acético por 20 minutos. Logo após, as lâminas foram lavadas três vezes de 2 minutos novamente em água destilada e em seguida foram deixados em estufa por 20 minutos para secar. Daí, as lâminas foram mergulhadas em xilol 2 vezes de 3 minutos e cobertas com lamínulas, aderidas com DPX (Fluka, Milwukee, WI, USA). Em seguida o material foi analisado ao microscópio de fluorescência. 


\subsection{Alteração de neurópila no colículo superior de ratos por INJEÇÃO DE BDA}

Utilizamos o traçador anterógrado amino-dextrana biotinilada (do inglês, biotinylated dextran amine - BDA) para observarmos possíveis modificações em terminais córtico-coliculares no colículo superior após uma enucleação ocular.

Para realizarmos a injeção de BDA nas camadas $\mathrm{V}$ e VI do córtex visual, anestesiamos dois ratos que foram inicialmente submetidos a enucleação ocular, sobrevida de 15 dias, e colocamos os animais em um aparelho estereotáxico (David Kopf). Em seguida, medimos as coordenadas com o aparelho estereotáxico, tendo como base de localização um atlas anatômico (Paxinos e Watson, 2005). Expomos os crânios dos animais e foi feita uma pequena janela para introdução de uma micropipeta, a fim de atingirmos as camadas $\mathrm{V}$ e $\mathrm{VI}$ do córtex visual, referências: interaural 3,48 mm e bregma 5,52 mm (Paxinos e Watson, 2005). Após a penetração da micropipeta no córtex, foram realizadas 3 pulsos de pressão de ar para injeção do traçador $(2 \mu \mathrm{l})$ em cada hemi-córtex. Após esse procedimento, esperamos durante 5 minutos, retiramos a micropipeta e preenchemos o espaço aberto no crânio com um material sintético de fibrina (Gelfoam, Upjohn) para uma evitar sangramentos. Em seguida, suturamos a pele do animal.

Quinze dias após a injeção, os ratos foram submetidos à perfusão transcardíaca, como descrito anteriormente e seus encéfalos foram crioprotegidos por $48 \mathrm{~h}$, cortados e coletados em PB. Em seguida incubamos seções de cortes em uma solução de avidina-biotina-peroxidase (ABC Elite, Vector Labs.) por 2 horas. Após 3 lavagens de 10 minutos, os cortes foram imersos em reação com 0,05\% de 3-3'-diaminobenzidina (DAB) e uma solução $0,01 \%$ de peróxido de hidrogênio em PB. Após montagem dos cortes em lâminas gelatinizadas, as mesmas foram colocadas em placa quente por $12-18 \mathrm{~h}$ e submetidas a uma solução de $0,05 \%$ de tetróxido de ósmio a fim de intensificar a marcação do traçador. As lâminas contendo os cortes reagidos foram desidratadas em uma série de álcoois e xilol e cobertas com lamínula usando-se Permount (Fisher). Os cortes foram analisados ao microscópio de luz. 


\subsection{QuANTIFICAÇÃO DA EXPRESSÃo GÊNICA DE mGLURS POR RT-PCR EM} TEMPO REAL

A extração do RNA total de cada colículo superior $(n=20)$ foi realizada pelo método do TRIzol ${ }^{\circledR}$, seguindo as instruções do fabricante. A seguir, efetuamos o protocolo padrão de transcrição reversa, utilizando a enzima SuperScript III. Para os estudos de quantificação de expressão gênica realizamos experimentos utilizando 0 PCR Real-Time (Applied Biosystems-GeneAmp 5700). Neste sistema, a amplificação da seqüência alvo é detectada em tempo real pela emissão de fluoróforo, que ocorre quando há formação de dupla fita na região codificada pelo par de primers. A quantificação da amplificação é feita pela fluorescência captada pela unidade óptica do aparelho (Figura 5). Pelas características do sistema, no PCR Real-Time é possível determinar todo o perfil de amplificação, o que representa uma de suas vantagens metodológicas (Schmittgen et al., 2000; Kihara et al., 2005).

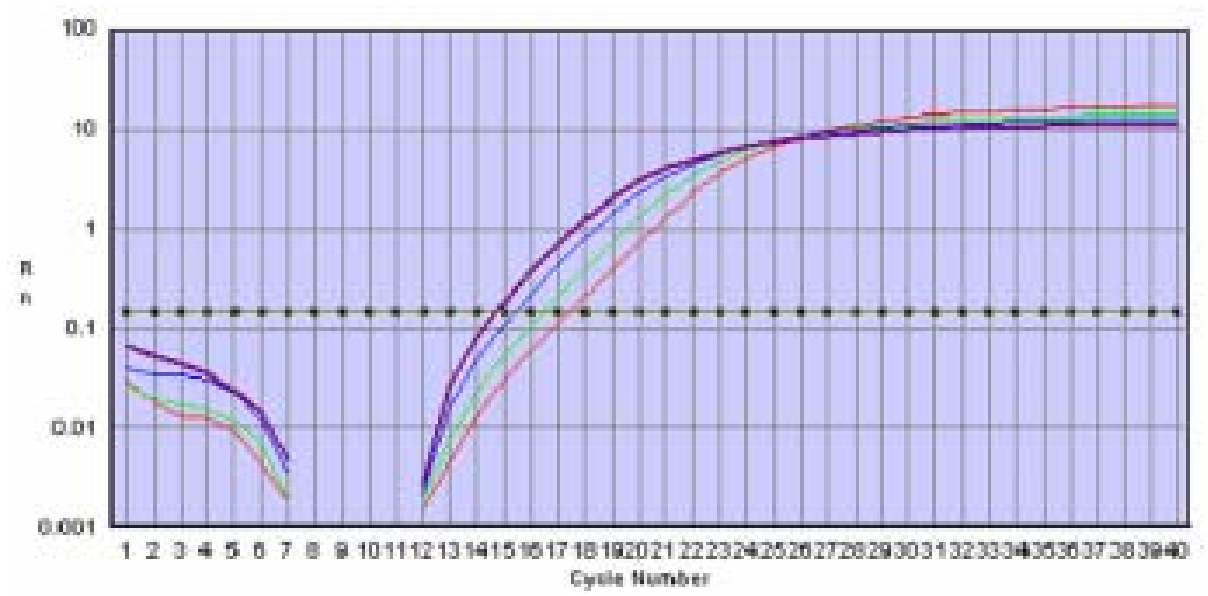

Figura 5. Experimento com diferentes quantidades de cDNA (5, 10, 20 e $40 \mathrm{ng})$ utilizando primers para mGluRs. As curvas representam a fluorescência detectada pelo sistema (ordenada) em função do número de ciclos (abcissa). Quanto menor a quantidade inicial de cDNA maior o número de ciclos necessários para se atingir o mesmo nível de fluorescência normalizada, ou seja, o mesmo número de cópias do fragmento amplificado (amplicon).

O PCR Real-Time pode ser realizado por meio dos sistemas TaqMan ou SYBR Green. No sistema SYBR Green, que utilizamos aqui, o fluoróforo se encontra no tampão do PCR: em cada fase de anelamento, o fluoróforo se intercala na dupla fita, liberando a fluorescência que é proporcional ao número de cópias. Neste sistema, a validação do resultado passa por um processo chamado de curva 
de dissociação: o produto do PCR é aquecido de $60^{\circ}$ até $90^{\circ} \mathrm{C}$, o que leva à separação da dupla fita, com conseqüente diminuição da fluorescência. Com a curva de dissociação, é possível determinar a especificidade da amplificação (Figura $6)$.

A)

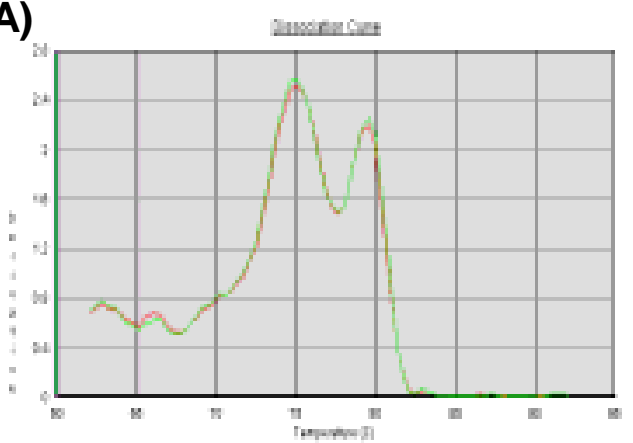

B)

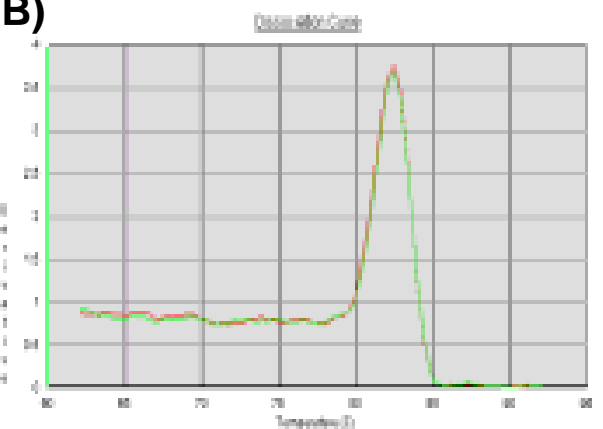

Figura 6. Curva de dissociação com $(A)$ e sem (B) produtos inespecíficos. A ordenada corresponde à derivada da fluorescência detectada e a abscissa à temperatura. (A) os picos em 2 temperaturas indicam que pelo menos 2 produtos foram gerados na amplificação do PCR; em (B), o pico único indica a produção de apenas um produto, que coincide com o Tm teórico do amplicon esperado.

A extração do RNA do colículo superior foi realizada isoladamente para cada amostra. Após a coleta, o material foi manualmente macerado em $1 \mathrm{ml}$ do Reagente Triß (TRIzol, Life Technology, EUA). Ao macerado foram adicionados $200 \mu \mathrm{l}$ de clorofórmio, seguido de agitação durante 15 segundos. Após este período, as amostras foram centrifugadas $\left(12000 \mathrm{rpm}, 4^{\circ} \mathrm{C}\right)$ durante $15 \mathrm{~min}$. A fase aquosa resultante foi transferida para um eppendorf e a este adicionados $500 \mu \mathrm{l}$ de isopropanolol. O material foi incubado durante $10 \mathrm{~min}$., à temperatura ambiente. As amostras foram então centrifugadas por $10 \mathrm{~min}$. (12000 rpm, $4^{0} \mathrm{C}$ ) e o sobrenadante descartado. O precipitado contendo o RNA foi lavado com $1 \mathrm{ml}$ de etanol $75 \%$ e centrifugado novamente por $10 \mathrm{~min}$ (7500 rpm). O sobrenadante foi descartado e o precipitado ressuspendido em $18 \mu \mathrm{l}$ de água livre de RNAse (Promega, EUA). A concentração de mRNA foi quantificada por espectrofotômetro em 260nm. Para cada uma das amostras analisadas, $2 \mu \mathrm{g}$ de RNA obtidos foram adicionados a uma solução contendo tampão de transcrição reversa $(10 \mathrm{mM}$ de Tris- $\mathrm{HCL}, 50 \mathrm{mM}$ de $\mathrm{KCl}$ e $0,1 \%$ de Triton X-100). A expressão dos mRNAs dos genes mGluR1, mGluR2, $m$ GluR3, mGluR5 e $m$ GluR7 foi realizada por reação de transcrição reversa seguida de amplificação por PCR em tempo real utilizando o equipamento automatizado ABI Prism 5700 (Applied Biosystems, Foster City, CA, USA). Para a quantificação da expressão gênica foi utilizado o método de quantificação relativa, utilizando o gene constitutivo da gliceraldeído-3-fosfato desidrogenase (GAPDH) como referência. A 
reação de real-time tanto para o gene GAPDH como para os mGluRs estudados foi realizada a partir de $250 \mathrm{nM}$ de cada primer, $50 \mathrm{ng}$ de cDNA e 1X SYBRß Green PCR Master Mix (Applied Biosystems, Foster City, CA, USA). As condições de reação de amplificação foram: após um ciclo inicial a $50^{\circ} \mathrm{C}$ por 2 min e $95^{\circ} \mathrm{C}$ por 10 min, foram realizados 40 ciclos de $95^{\circ} \mathrm{C}$ por $15 \mathrm{~s}$ e $60^{\circ} \mathrm{C}$ por $1 \mathrm{~min}$. Para realização da curva de dissociação, ao final dos ciclos, a temperatura foi elevada de $60^{\circ} \mathrm{C}$, com incremento de $1^{\circ} \mathrm{C}$ a cada $5 \mathrm{~s}$, até $90{ }^{\circ} \mathrm{C}$. Os seguintes pares de primers para mGluR1, mGluR2, mGluR3, mGlur5 e mGluR7 (Ghasemzadeh et al., 1996) e GAPDH que foram utilizados na reação estão descritos na Tabela 2. Os primers específicos para esses receptores foram desenhados por meio do programa Primer Express (Applied Biosystems), sintetizados e purificados por HPLC (Invitrogen).

\begin{tabular}{|l|l|l|}
\hline \multicolumn{1}{|c|}{ Primer } & \multicolumn{1}{c|}{ Forward } & \multicolumn{1}{c|}{ Reverse } \\
\hline mGluR1 & CCAACGGAGGGATCACAATAA & TCCAGCCTCAGCTTCAGGAA \\
\hline mGluR2 & TGGCACAGGCAAGGAGACA & CGGTGGTTACAGCGCAATG \\
\hline mGluR3 & TGCCTCTGAGGGTGACTATGG & ATGTTACGCAGCCGTGCTT \\
\hline mGluR5 & TTGTGGCAGCGACTGTCTGT & TCTTGGGAAAGGGTTTGATGA \\
\hline mGluR7 & GGCCGTCGTGATTTTTGC & TGGCCTACTTGGTCAGCTCTTT \\
\hline GAPDH & GATGCTGGTGCTGAGTATGTCG & GTGGTGCAGGATGCATTGCTGA \\
\hline
\end{tabular}

Tabela 2. Primers desenhados para estudo dos mGluRs (de ratos) e primer do gene constitutivo de referência GAPDH.

A quantificação relativa da expressão do gene alvo foi executada utilizando o método comparativo de limiar de ciclos (CT) como anteriormente descrito (Medhurst et al., 2000). O valor de $\Delta$ CT foi determinado subtraindo o alvo CT de cada amostra do valor respectivo de GAPDH. O cálculo de $\triangle \mathrm{CT}$ envolveu o valor médio de $\Delta \mathrm{CT}$ do grupo controle como uma constante arbitrária para subtrair de todos valores médios restantes de $\triangle \mathrm{CT}$.

\subsection{QUANTIFICAÇÃO DE PROTEÍNAS MGIURS POR IMMUNOBLOTTING}

Após tempos de sobrevida distintos os animais, cinco para cada sobrevida, foram sacrificados por deslocamento cervical e as áreas visuais primárias, CS e complexo geniculado lateral, foram rapidamente coletadas e homogeneizadas a $4^{\circ} \mathrm{C}$ em tampão de extração (Tris pH 7,4 100 mM, EDTA 10 mM, PMSF 2 mM e 
aprotinina $0,01 \mathrm{mg} / \mathrm{ml}$ ) com um homogenizador do tipo Turratec modelo MA-102/mini (Marconi; São Paulo, Brasil). As amostras foram centrifugadas por 20 minutos a 12.000 rpm em uma microcentrífuga refrigerada modelo CT 14000 DR (Cientec, São Paulo, Brasil). O sobrenadante foi separado do "pellet" e reservado. O conteúdo protéico do material isolado foi determinado pelo método de Bradford (Amresco, USA) (Bradford, 1976), utilizando um kit para ensaio de proteínas (Bio-Rad; Hercules, CA, USA). As amostras dos homogenatos (75 $\mu \mathrm{g}$ de proteína) tratados com tampão Laemmli contendo DTT $100 \mathrm{mM}$ foram submetidas à eletroforese em géis de acrilamida a $6,5 \%$ contendo dodecil sulfato de sódio (SDS) utilizando uma cuba para mini-gel (Mini-Protean 3; Bio-Rad do Brasil; Rio de Janeiro, Brasil). Após a separação eletroforética, as proteínas foram eletro-transferidas para membranas de nitrocelulose $(0,45 \mu \mathrm{m}$ de diâmetro) utilizando-se um sistema de transferência (TransBlot cell system; Bio-Rad), em tampão contendo SDS. Após a transferência, as membranas foram incubadas em solução de bloqueio contendo $5 \%$ de leite desnatado em salina tamponada contendo Tween 20 (TTBS; 0,01 M de Tris- $\mathrm{HCl}, \mathrm{pH}$ $7,4,0,15 \mathrm{M}$ de $\mathrm{NaCl}, 0,05 \%$ de Tween 20) durante pelo menos quatro horas, sob agitação leve. Após esse período, as membranas foram lavadas 3 vezes de 10 minutos com TTBS e incubadas a $4^{\circ} \mathrm{C}$, sob leve agitação, durante toda a noite, com os mesmo anticorpos específicos para os mGluRs utilizados nos experimentos de imuno-histoquímica. Como controle interno dos experimentos utilizamos a $\beta$-actina (diluição do anticorpo, 1:1000). Em seguida, as membranas foram lavadas 3 vezes de 10 minutos em TTBS e posteriormente incubadas por 2 horas com um anticorpo secundário marcado com peroxidase (Amersham; Little Chalfont, Buckinghamshire, UK) diluído a 1:10000 em solução para incubação contendo $1 \%$ de leite desnatado em TTBS. Novamente as membranas foram lavadas em TTBS por 3 vezes de 10 minutos e a ligação específica do anticorpo com a proteína revelada utilizando o kit quimioluminescente ECL (Amersham Biosciences, NJ, EUA).

\subsection{ANÁLISE DA EXPRESSÃO DOS MGIURS E DA GLIOSE REATIVA POR IMUNO- HISTOQUÍMICA}

Após tempos pós-lesão de $1,7,15,30$ dias, os ratos $(n=20)$ e/ou os pintos lesionados $(n=20)$ foram anestesiados e submetidos à perfusão transcardíaca com 
salina tamponada e paraformaldeído (PFA) a 2\% em tampão fosfato $0,1 \mathrm{M}$ (PB, pH $7,4)$. Os encéfalos foram retirados da caixa craniana e mantidos por um período de 30 minutos de pós-fixação e logo após foram transferidos para uma solução de sacarose a $30 \%$ em PB para crioproteção por um período de $48 \mathrm{~h}$. Os encéfalos foram cortados no plano coronal em uma espessura de $30 \mu \mathrm{m}$ em um micrótomo deslizante de congelamento. Os cortes foram submetidos à metodologia imunohistoquímica para a detecção dos receptores metabotrópicos: mGluR1, mGluR5, mGluR2/3 e mGluR 7. Salientemos que para mGluR2 e mGluR3, o anticorpo reconhece um sítio de ligação nesses dois receptores. Detectamos também a proteína acídica fibrilar glial (GFAP) encontrada em astrócitos, para a verificação da extensão da lesão.

Resumidamente, esses cortes foram incubados com anticorpos policlonais anti-mGluR1, mGluR5 e mGluR7 (1:1000) e mGluR2/3 (1:500) (Chemicon) feitos em coelho diluídos em PB contendo 0,3\% de Triton X-100. Para o anti-GFAP, feito em camundongo, utilizamos a concentração de 1:1000. As incubações com os anticorpos primários foram feitas por períodos de 14 a 18 horas. Como controle negativo, incubamos uma seção de cortes omitindo o primário de cada proteína avaliada. Em seguida, realizamos 3 lavagens (10 minutos cada) em PB e a seguir, os cortes foram incubados com anticorpos secundários, biotinilados (Vector Labs., Burlingame, CA) diluídos a 1:200 em PB por aproximadamente 2 horas à temperatura ambiente, novamente lavados como anteriormente em PB e incubados com uma solução de avidina-biotina-peroxidase (ABC Elite, Vector Labs.) por 2 horas. Em seguida a essa etapa, os cortes foram imersos em reação com $0,05 \%$ de 3-3'-diaminobenzidina (DAB) e uma solução 0,01\% de peróxido de hidrogênio em PB. Após montagem dos cortes em lâminas gelatinizadas, as mesmas foram colocadas em placa quente por $12-18 \mathrm{~h}$ e submetidas a uma solução de $0,05 \%$ de tetróxido de ósmio a fim de intensificar a imunorreatividade para os mGluRs. As lâminas contendo os cortes reagidos foram desidratadas em uma série de álcoois e xilol e cobertas com lamínula usando-se Permount (Fisher). A imunorreatividade no colículo superior (CS), núcleo geniculado lateral (NGL) e Tecto Óptico (TeO) foi analisada ao microscópio de luz e quantificações foram realizadas com o programa Image (NIH-USA). 


\subsubsection{IDENTIFICAÇÃO DE NEURÓPILA EM PINTOS POR INJEÇÃO DE BIOCITINA "IN VITRO"}

Utilizamos um traçador neuronal, a biocitina, nos núcleos Imc e Ipc que se projetam para as camadas superficiais do $\mathrm{TeO}$, para identificarmos os terminais neuronais que continham um possível subtipo de mGluRs em áreas superficiais do $\mathrm{TeO}$ de pintos. Assim, utilizamos três pintos que foram anestesiados e em seguida decapitados. Os encéfalos foram removidos rapidamente da caixa craniana e colocados em uma placa de vidro contendo solução artificial de sacarose previamente oxigenada (solução 1: $240 \mathrm{mM}$ de sacarose, $3 \mathrm{mM}$ de $\mathrm{KCL}$, $3 \mathrm{mM}$ de $\mathrm{MgCl}_{2}, 23 \mathrm{mM} \mathrm{NaHCO}, 1,2 \mathrm{mM} \mathrm{NaH} \mathrm{PO}_{4}, 11 \mathrm{mM}$ de D-glicose). A seguir a região do $\mathrm{TeO}$ foi seccionada no plano apropriado entre $1000 \mu \mathrm{m}-2000 \mu \mathrm{m}$ com auxílio de uma lupa e de um atlas estereotáxico. Os cortes foram coletados contendo outra solução (solução 2: $119 \mathrm{mM}$ de $\mathrm{NaCl}, 2,5 \mathrm{mM}$ de $\mathrm{KCl}, 1,3 \mathrm{mM}$ de $\mathrm{Mg}_{2} \mathrm{SO}_{4}, 1 \mathrm{mM}$ de $\mathrm{NaH}_{2} \mathrm{PO}_{4}, 1 \mathrm{mM}$ de $\mathrm{NaH}_{2} \mathrm{PO}_{4}, 26,2 \mathrm{mM} \mathrm{NaHCO} 3,11 \mathrm{mM}$ de D-glicose, 2,5 mM de $\left.\mathrm{CaCl}_{2}\right)$ à temperatura ambiente e continuamente oxigenada com carbogênio (95\% de $\mathrm{O}_{2}, 5 \%$ de $\mathrm{CO}_{2}$ ).

Após o preparo inicial, depositamos cristais de biocitina (Sigma, St. Louis, MO) no Ipc e Imc e aguardamos por 2 minutos. Em seguida colocamos os cortes contendo o traçador em tubo contendo a solução 2 e mantivemos oxigenando-os por 4 horas à temperatura ambiente. Subseqüentemente, os cortes foram fixados em paraformaldeído a $4 \%$ em PB por $2 \mathrm{~h}$ e transferidas para sacarose a $30 \%$ em PB por um período de 48h. Em seguida, o material foi seccionado no plano coronal em uma espessura de $30 \mu \mathrm{m}$ em um micrótomo deslizante de congelamento e os cortes coletados em PB. Realizamos uma pré-incubação nos cortes com $0,03 \%$ de peróxido de hidrogênio $\left(\mathrm{H}_{2} \mathrm{O}_{2}\right)$ por 10 minutos, para bloqueio de peroxidase endógena e lavamos em seguida. Algumas seções foram incubadas com anticorpos primários contra mGluR2/3 diluídos em Triton X-100 a 0,3\% em PB em uma concentração de 1:100 por 12-24 $\mathrm{h}$ à temperatura ambiente. A seguir, os cortes foram lavados 3 vezes por 10 minutos em PB. A seguir, incubamos essas mesmas seções com estreptavidina por 2 horas diluídas em Triton X-100 a 0,3\% em PB. Após esse procedimento, os cortes foram incubados com anticorpos secundários (Jackson Labs.) marcados com diferentes fluoróforos: isotiocianato de fluoresceína 
(FITC), para visualizamos o traçador, e tetrametil isotiocianato de rodamina (TRITC), para visualizarmos o mGluR2/3, dirigidos contra a IgG dos animais onde os anticorpos primários foram produzidos. Esses anticorpos secundários foram diluídos a 1:50 em PB, mantidos por $2 \mathrm{~h}$ à temperatura ambiente. A seguir, os cortes foram lavados 3 vezes em PB e montados em lâminas gelatinizadas. Após a montagem, as lâminas foram mantidas à temperatura ambiente e protegidas da luz por 20 minutos, para os cortes aderirem à lâmina. Em seguida, as mesmas foram cobertas com glicerol e tampão carbonato e lamínulas. O material processado foi observado em microscopia de fluorescência com os filtros apropriados e a imagens digitais coletados em microscópio confocal.

\subsection{COLORAÇÃO DE GIEMSA}

Para visualização da citoarquitetura, alguns cortes foram submetidos à coloração com Giemsa. Após colocação dos cortes em lâminas gelatinizadas, essas foram deixadas por aproximadamente $24 \mathrm{~h}$ em uma placa de aquecimento a $37^{\circ} \mathrm{C}$ para melhor adesão dos cortes nas lâminas.

As lâminas foram então colocadas por 1 hora em uma solução de clorofórmio e álcool etílico $95 \%$. Em seguida, o tecido foi reidratado numa bateria de álcoois $90 \%, 70 \%$ e finalmente água deionizada com duração, em cada etapa, de cinco minutos. As lâminas foram colocadas na solução de Giemsa previamente aquecida a $60 \stackrel{\circ}{\circ}$ por 7 minutos e a seguir foram lavadas rapidamente em PBS 0,1 M. Após esses procedimentos, as lâminas foram colocadas em uma solução de $1 \%$ de molibdato de amônia por 5 minutos, fixando a marcação. Em seguida, as lâminas foram lavadas com água deionizada, passando em seguida por uma bateria de desidratação em álcoois e por um solvente clareador (Hemo-De, Fisher) com duração de 5 minutos em cada estágio como foi anteriormente descrito e, por fim, as lâminas com os cortes foram cobertas com lamínulas.

\subsection{ANÁLISE DE DADOS}

Como descrito anteriormente utilizamos a quantificação relativa da expressão do gene alvo. O valor de $\Delta \mathrm{CT}$ foi determinado subtraindo o alvo $\mathrm{CT}$ de cada amostra 
do valor respectivo de GAPDH. O cálculo de $\triangle \mathrm{CT}$ envolveu o valor médio de $\triangle \mathrm{CT}$ do grupo controle como uma constante arbitrária para subtrair de todos valores médios dos $\triangle C T$ dos genes estudados. Utilizamos a regressão linear das curvas geradas por diluições seriadas de cDNA, variando de 2 a 16ng de cDNA, para observar a amplificação linear para o controle interno, o GADPDH.

As bandas obtidas com o procedimento de immunoblotting foram analisadas densitometricamente com o programa NIH-Scion Image 4.0.2 (Scion Corporation; Frederick, MD, USA). A densidade encontrada foi considerada 100\% para a análise comparativa entre o lado controle e o experimental. Quantificamos também as bandas do controle interno por meio de densidade óptica, observando se houve variação protéica entre o controle e experimental. Os resultados descritos estão representados em gráficos para cada dia analisado e ilustrados por imagens das bandas específicas.

A imunorreatividade foi analisada por meio de microscópio de luz (Leitz) acoplado a um sistema de imagens composto de câmera de vídeo e computador Macintosh com placa de aquisição de vídeo e o programa Image (NIH). Em seguida, fez-se uma comparação qualitativa entre os lados controle e experimental, a fim de avaliar a imunorreatividade para os mGluRs no colículo superior e no complexo geniculado lateral em cada animal nos diferentes tempos de sobrevida estudados.

Com auxílio deste programa foram feitas as quantificações após captura da imagem e delimitação da região do CS e NGL em ratos e TeO em pintos que continham imunorreatividade para os receptores estudados. Foram considerados imunorreativos apenas a neurópila e os pericários que se destacavam bastante do ruído de fundo produzido pelo método da imunoperoxidase. Foram feitas contagens de densidade de neurópila imunorreativa para mGluR1 e mGluR5 e de quantidade de pericários imunorreativos para mGluR7 na zona marginal e camada cinzenta superficial do CS e no complexo geniculado lateral dorsal e lateral em ratos. Realizamos as contagens em quatro cortes do encéfalo de cada animal. Delimitamos as áreas numericamente iguais em 5 campos que envolveram as camadas superficiais do CS, tanto para o lado controle como para o experimental. Ao delimitar a mesma área, quantificávamos a densidade óptica da neurópila. Para análise, consideramos apenas as médias de cada animal. Para determinar o número de células imunorreativas por milímetro quadrado, calculamos a densidade relativa através da fórmula: 


$$
D=(n .1000000) / A\left(\mu m^{2}\right)
$$

$$
\begin{aligned}
& \mathbf{D}=\text { número de células marcadas por } \\
& \mathrm{mm}^{2} \\
& \mathbf{n}=\text { número de células marcadas } \\
& \mathbf{A}=\text { área delimitada para a contagem } \\
& \text { de célula em } \mu \mathrm{m}^{2}
\end{aligned}
$$

Para a análise comparativa da densidade óptica e número de pericários imunorreativos, consideramos $100 \%$ para o controle de cada estágio estudado. Os gráficos representam as variações experimentais com base no eixo da abscissa, que corresponde ao controle.

Para documentação, imagens digitais foram obtidas por meio de uma câmera acoplada a um microscópio Nikon; em seguida, as imagens foram transferidas para o computador e organizadas no programa Adobe Photoshop.

\subsubsection{Estatística}

As análises estatísticas da expressão gênica, da densidade das bandas, da densidade de marcação na neurópila e de densidade relativa de células imunorreativas no CS, NGL e TeO foram realizadas com o test " $\mathrm{t}$ " pareado, sendo a densidade da marcação ou o número de células imunorreativas a variável dependente. Para realizarmos os testes utilizamos o programa GraphPad Prism Versão 4.0. A significância estatística foi considerada admitindo-se um nível crítico de $p<0,05$ para rejeição da hipótese nula. 


\section{Resultados da Enucleação Ocular em Ratos e Pintos}

A Figura 7 ilustra as camadas do CS no qual observamos a zona marginal (Zo), camada cinzenta superficial (SuG), camada óptica (Op), camada cinzenta intermediária (InG), e camada branca intermediária do colículo superior ( $\operatorname{lnWh}$ ). Segundo a terminologia de (Langer e Lund, 1974), a camada superficial do colículo superior de mamíferos, conhecida como camada SuG, contém predominância de neurópila e pericários das células marginais, horizontais, verticais e piriformes. As camadas mais superficiais recebem projeções da retina e do córtex occipital e contêm células que se projetam para o núcleo geniculado do tálamo. Já as camadas profundas fazem conexões com várias estruturas do mesencéfalo e recebem aferências não-visuais (Sefton, 2004). Podemos observar ainda o complexo geniculado lateral dorsal (NGLd) e ventral (NGLv) que recebem aferências retinianas do olho contralateral e projeções do colículo superior. 
A)

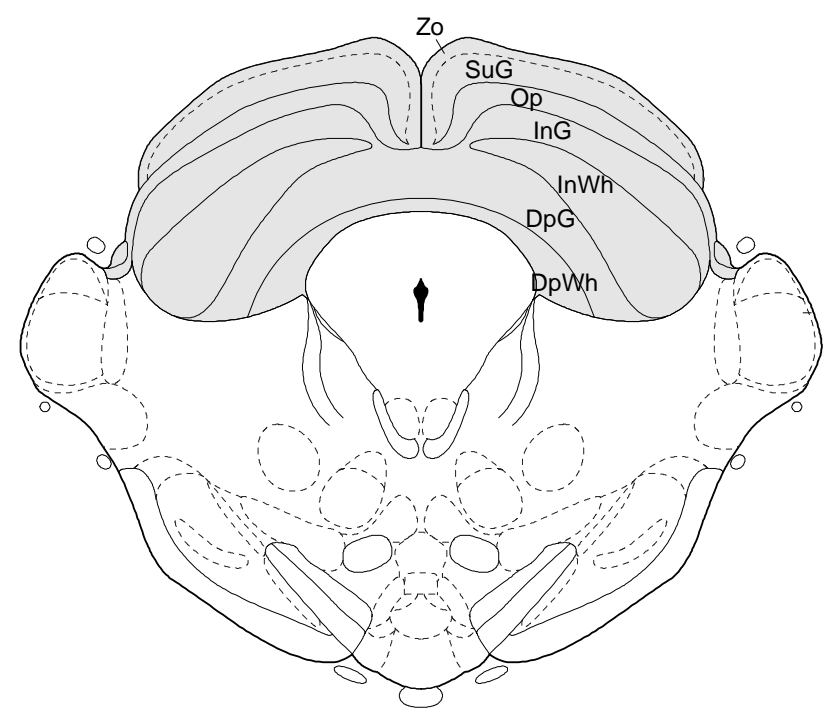

B)

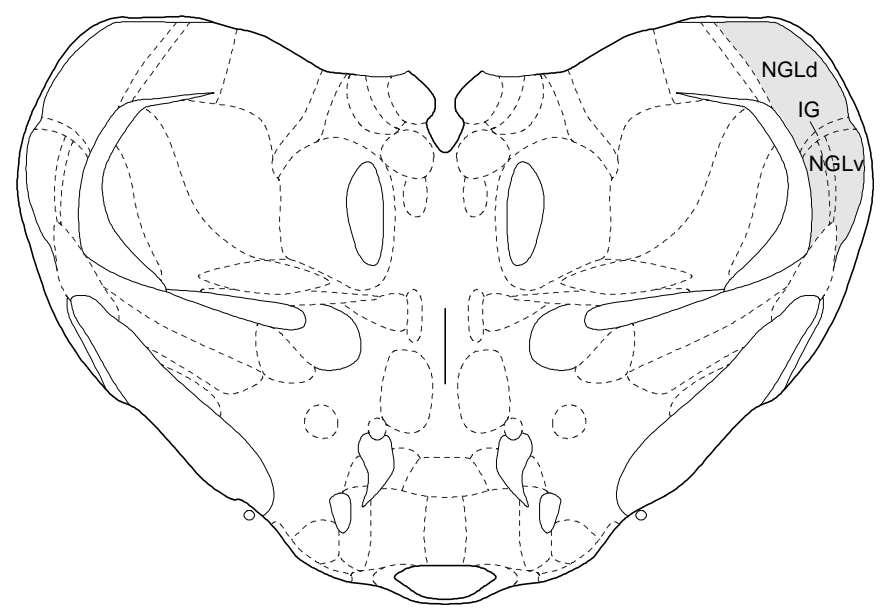

Figura 7. Ilustração de cortes coronais de encéfalo de ratos, mostrando o colículo superior (A) e suas camadas e o núcleo geniculado lateral (B). Zo: zona marginal; SuG: camada cinzenta superficial; Op: camada óptica; InG: camada cinzenta intermediária; InWh: camada branca intermediária do colículo superior. NGLd: núcleo geniculado dorsal; NGLv: núcleo geniculado ventral; IG: núcleo intergeniculado (Paxinos e Watson, 2005). 


\subsection{MORTE CELULAR E ENUCLEAÇÃO OCULAR EM RATOS E PINTOS}

No que se refere à morte celular nesse modelo, constatamos a ausência de células com fragmentação de DNA em todos os tempos de sobrevidas (1e 3 horas e 1, 7, 15, 30 e 60 dias pós-lesão) estudados no CS (imagens mostradas apenas do 1ำ e $30^{\circ}$ dias de sobrevida, Figura $8 \mathrm{~B}$ ) e no NGL (imagens não mostradas) de ratos e no TeO (imagens mostradas apenas do $1^{\circ}$ e $30^{\circ}$ dias de sobrevida, Figura 9B) de pintos. As células TUNEL-positivas apenas estavam presentes no nosso controle positivo, que envolvem células da retina que foram submetidas a intensa exposição à luz. Apoptose é característica deste modelo de degeneração (Figuras 8A e 9A). 

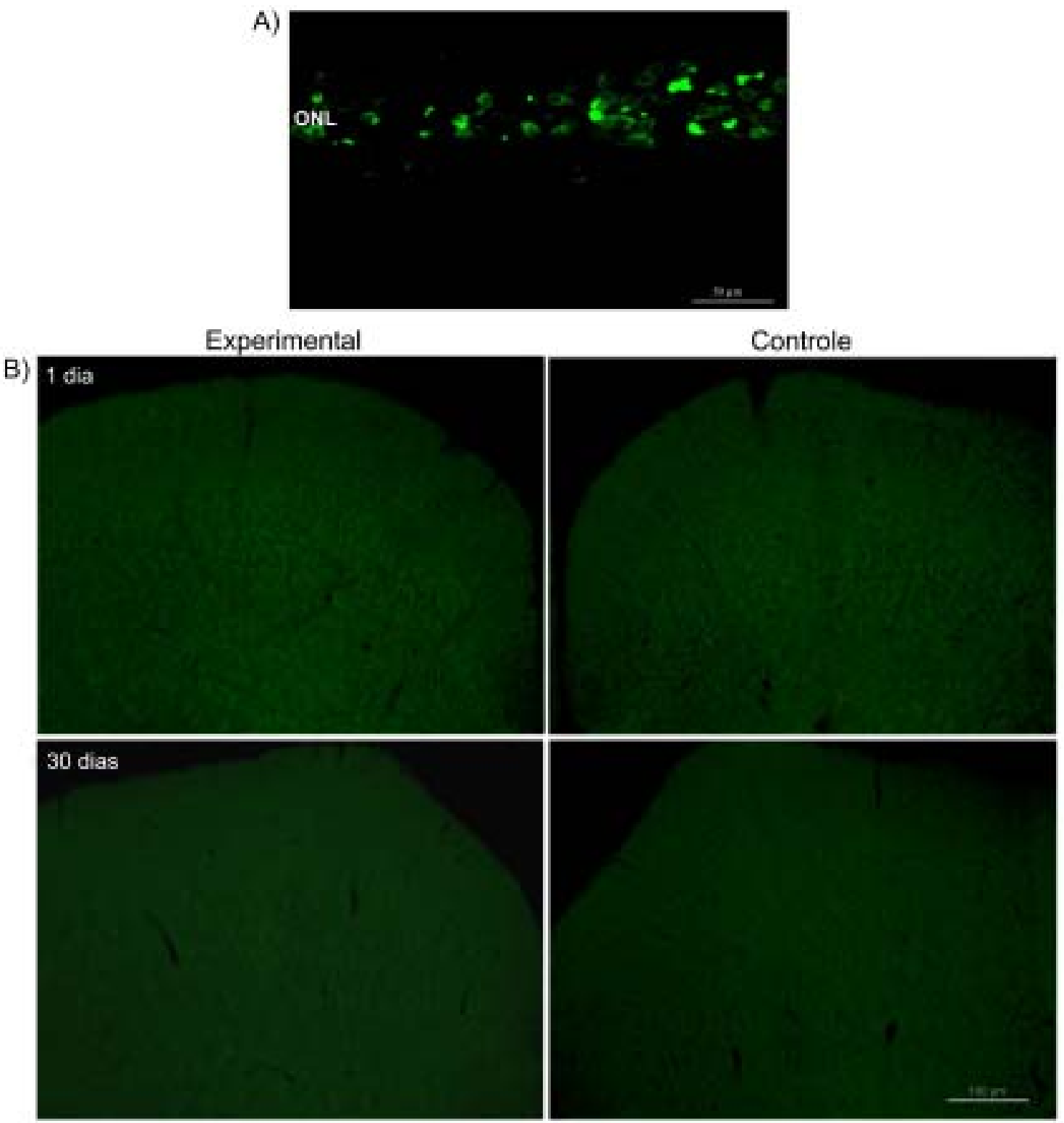

Figura 8. Imagens digitais de cortes coronais de encéfalo de rato, ilustrando o padrão de marcação por TUNEL na retina de camundongo, camada nuclear externa - ONL (A), após indução de degeneração e ausência de células reativas no CS após 1 e 30 dias pós-enucleação ocular (B). 


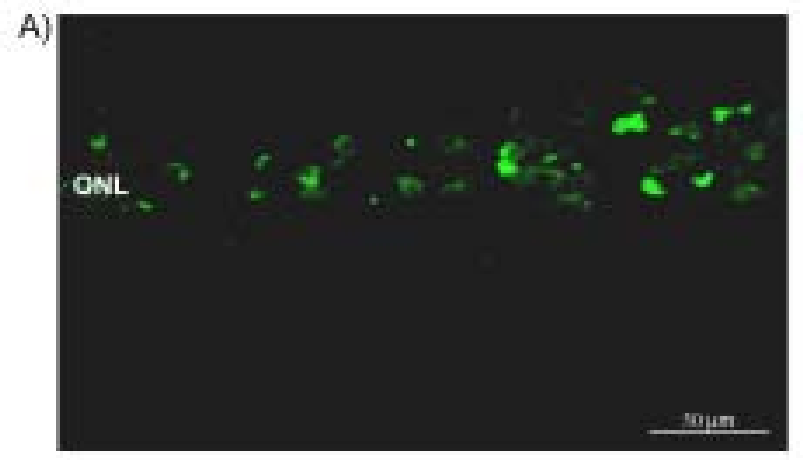

Experimental

Controle
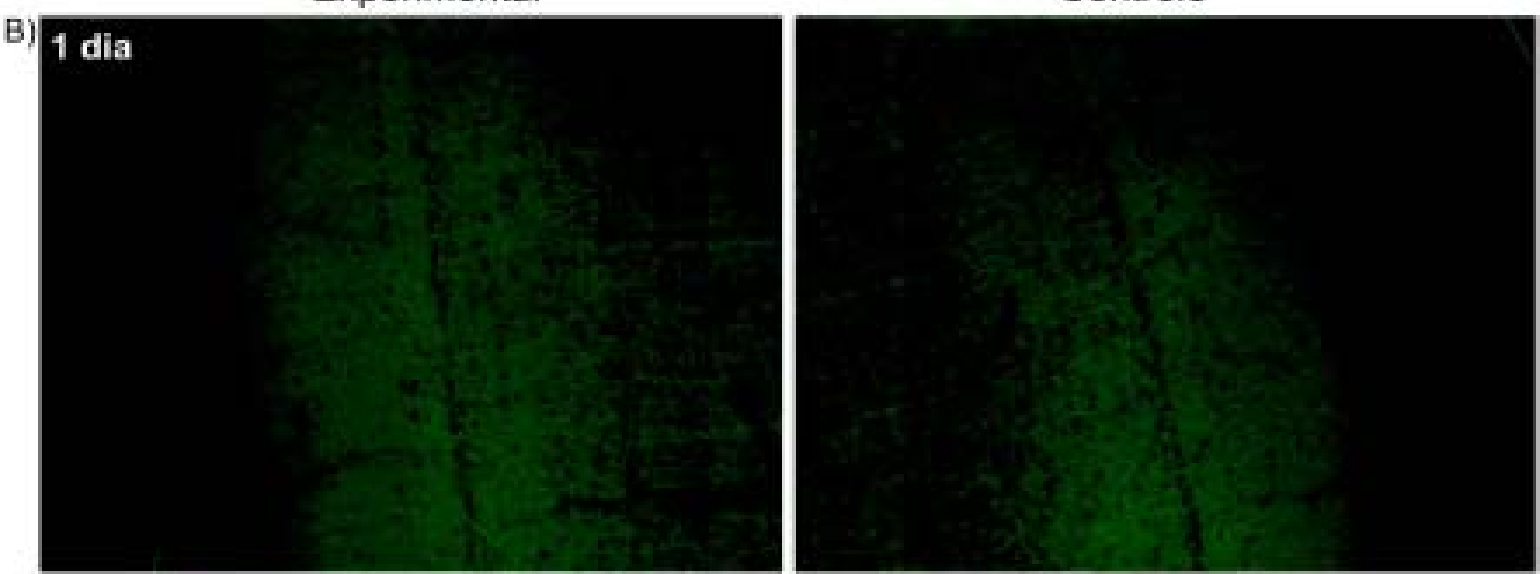

\section{0 dias}

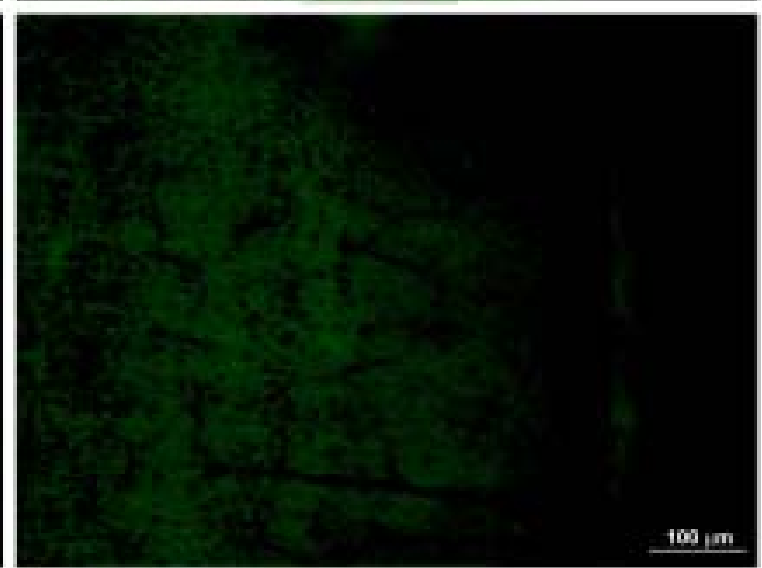

Figura 9. Imagens digitais de cortes coronais de encéfalo de pinto, ilustrando o padrão de marcação por TUNEL na retina de camundongo, camada nuclear externa - ONL (A), após indução de degeneração e ausência de células reativas no TeO após 1 e 30 dias pós-enucleação ocular (B). 


\subsection{Degeneração de fibras após enUCleação ocular em ratos e PINTOS}

Nossos dados com Fluoro-Jade em ratos mostraram que há degeneração de fibras após a enucleação ocular a partir do $7^{\circ}, 1^{\circ}$ e $30^{\circ}$ dias de sobrevida. A marcação no CS e NGL mostrou-se com um aspecto puntiforme (Figuras 10 e 11), podendo indicar apenas degeneração em fibras devido ao tipo de lesão que realizamos. Houve uma degeneração progressiva no decorrer dos dias avaliados. No $7^{0}$ dia, o aumento foi observado nas camadas óptica (Op) e superficial cinzenta (SuG). À medida que o tempo de sobrevida foi aumentando, visualizamos mais terminais no lado experimental, permeando a SuG e Zo (Figura 10). O mesmo resultado foi observado no NGLd (Figura 11) e em menor proporção no NGLv (imagem não mostradas).

Em pintos, observamos raras fibras em degeneração nas camadas retinorrecipientes; visualizamos um grande contingente de fibras no nervo óptico nos dias 15 e 30 após a enucleação ocular (Figura 12). No 30ํำ de lesão observamos fibras em degeneração nas camadas 1, 2 e 3 do TeO na região ventro-medial.

A marcação por Fluoro-Jade B foi observada também no lado controle, sendo que houve raros pontos marcados, provavelmente provenientes das pouquíssimas projeções ipsolaterais encontradas em ratos e em pintos. 


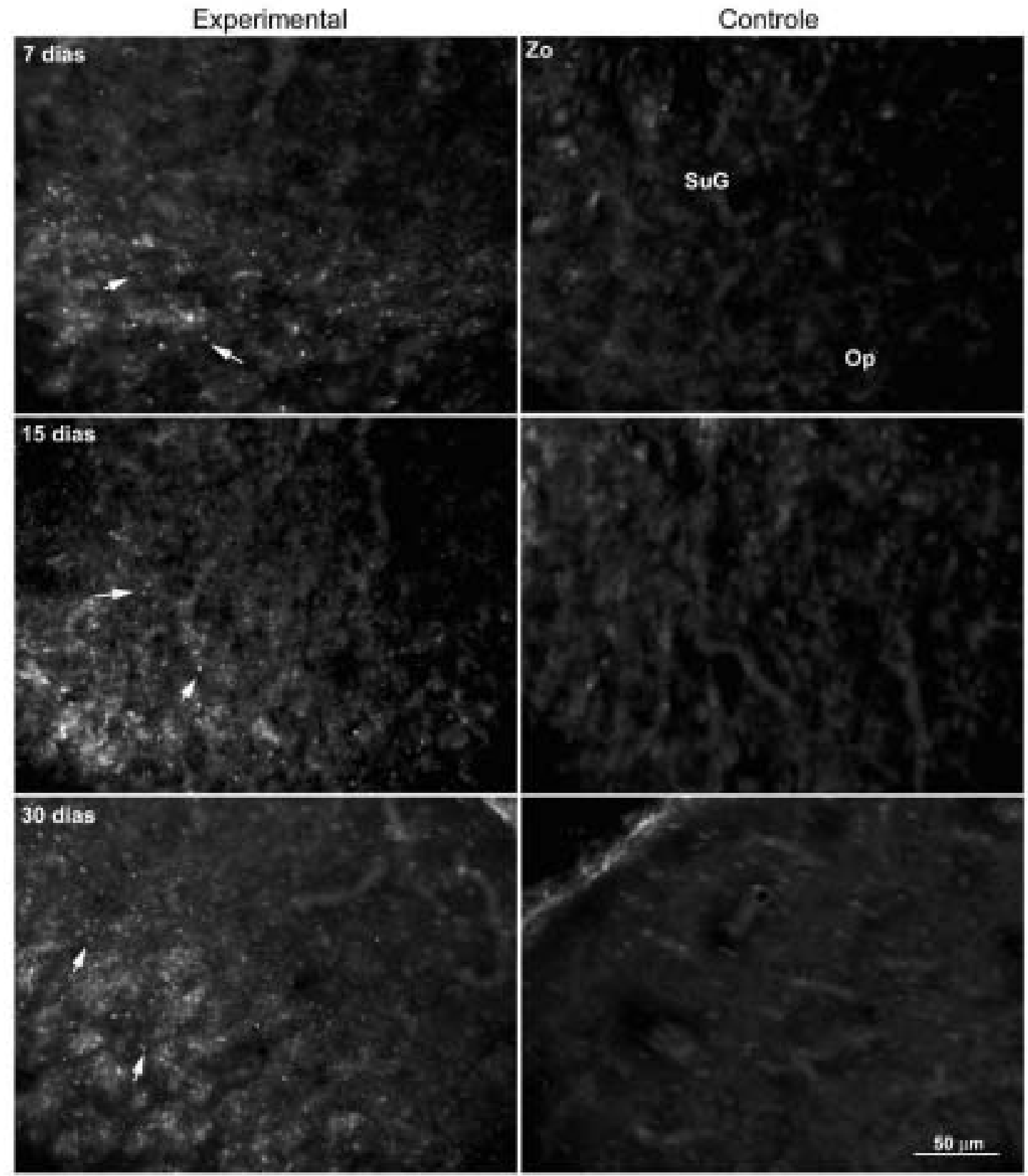

Figura 10. Imagens digitais de cortes coronais de encéfalo de rato, mostrando a marcação puntiforme (setas) de Fluoro-Jade em fibras em degeneração nas camadas superficiais do CS no $7^{\circ}, 15^{\circ}$ e $30^{\circ}$ dias pós-lesão. 

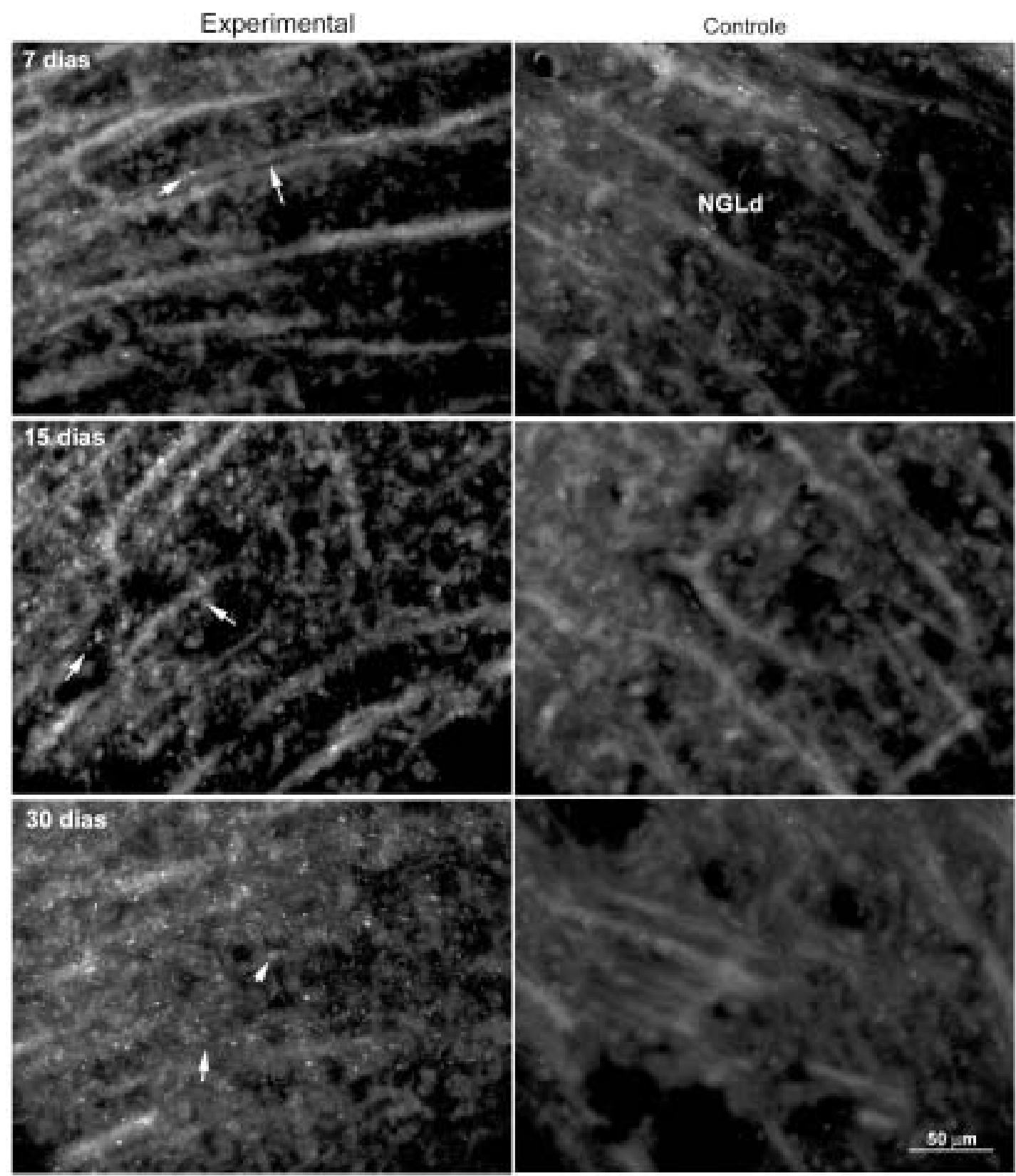

Figura 11. Imagens digitais de cortes coronais de encéfalo de ratos, mostrando a marcação puntiforme (setas) de Fluoro-Jade em fibras em degeneração no NGLd nos $7^{\circ}, 15^{\circ}$ e $30^{\circ}$ dias pós-lesão. 


\section{Experimental}
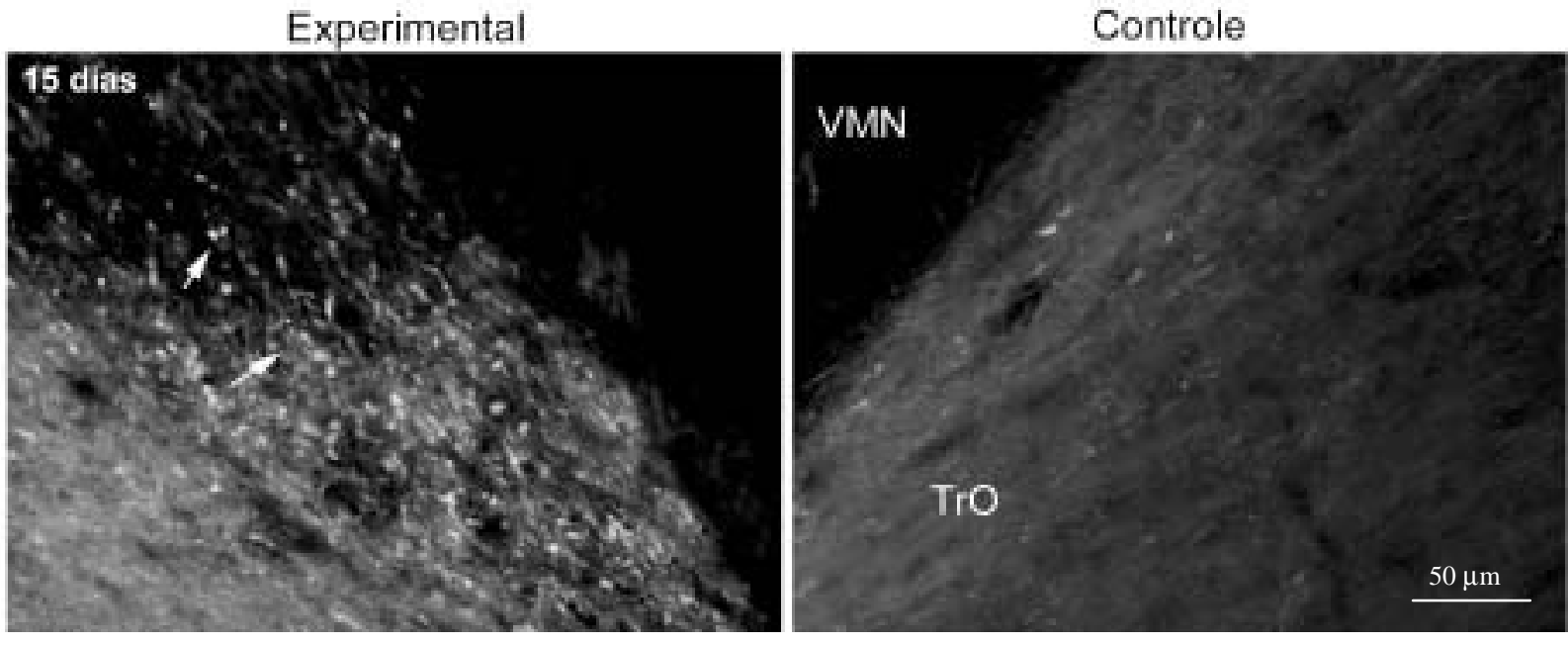

Figura 12. Imagens digitais de cortes coronais de encéfalo de pintos, mostrando a marcação (setas) de Fluoro-Jade em fibras em degeneração no nervo óptico após 15 dias após enucleação. TrO: tracto óptico; VMN: núcleo ventromedial hipotalâmico. 


\subsection{MODIFICAÇÕES NA ORGANIZAÇÃo SINÁPTICA NO COLíCULO SUPERIOR DE}

\section{RATOS}

Após o período de 30 dias pós-lesão, encontramos modificações na organização dos terminais axonais nas camadas Zo, SuG, Op e InG após injeção do traçador BDA no nas camadas $\mathrm{V}$ e VI do córtex visual. Observamos um aumento de fibras nas camadas superficiais do CS no lado experimental, sendo que a marcação se restringiu a fibras neuronais (Figura 13). Nossos dados indicam aumento de prolongamentos e rearranjos em fibras neuronais dos terminais córtico-coliculares após uma enucleação ocular em longo prazo.
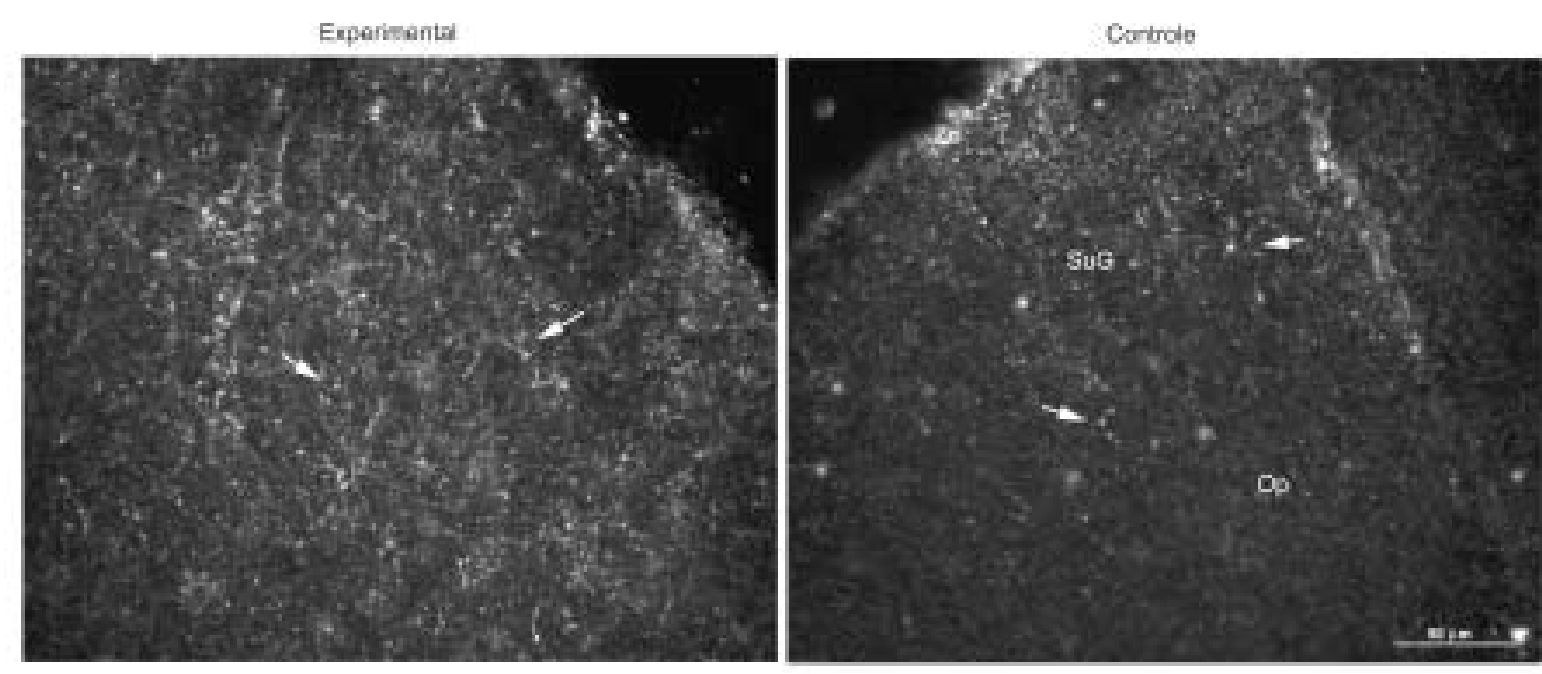

Figura 13. Imagens digitais de cortes coronais de encéfalo de rato, mostrando o aspecto da marcação e o aumento de neurópila nas camadas superficiais do CS, após injeção do BDA no córtex de ratos. 


\subsection{REAÇÃo GLIAL APÓS ENUCLEAÇÃO OCULAR}

Observamos na Figura 14 a expressão de GFAP no CS e na Figura 15, no TeO. A presença de células gliais pode indicar a intensidade da lesão pelo número de células gliais e aumento de processos na área afetada. A gliose reativa parece ter duas principais funções dentre as inúmeras desconhecidas, dentre elas a de isolar e de ocupar o local lesionado, permitindo assim o crescimento e o favorecimento das sinapses (Lenz et al., 1997). Em nossos dados, visualizamos a reação glial que foi proporcional à sobrevida da lesão no lado experimental, no qual o maior aumento foi no $30^{\circ}$ dia pós-lesão. A reação glial foi observada tanto no CS (Figura 14) e NGL de ratos, como no TeO de pintos (Figura 15). 


\section{GFAP}
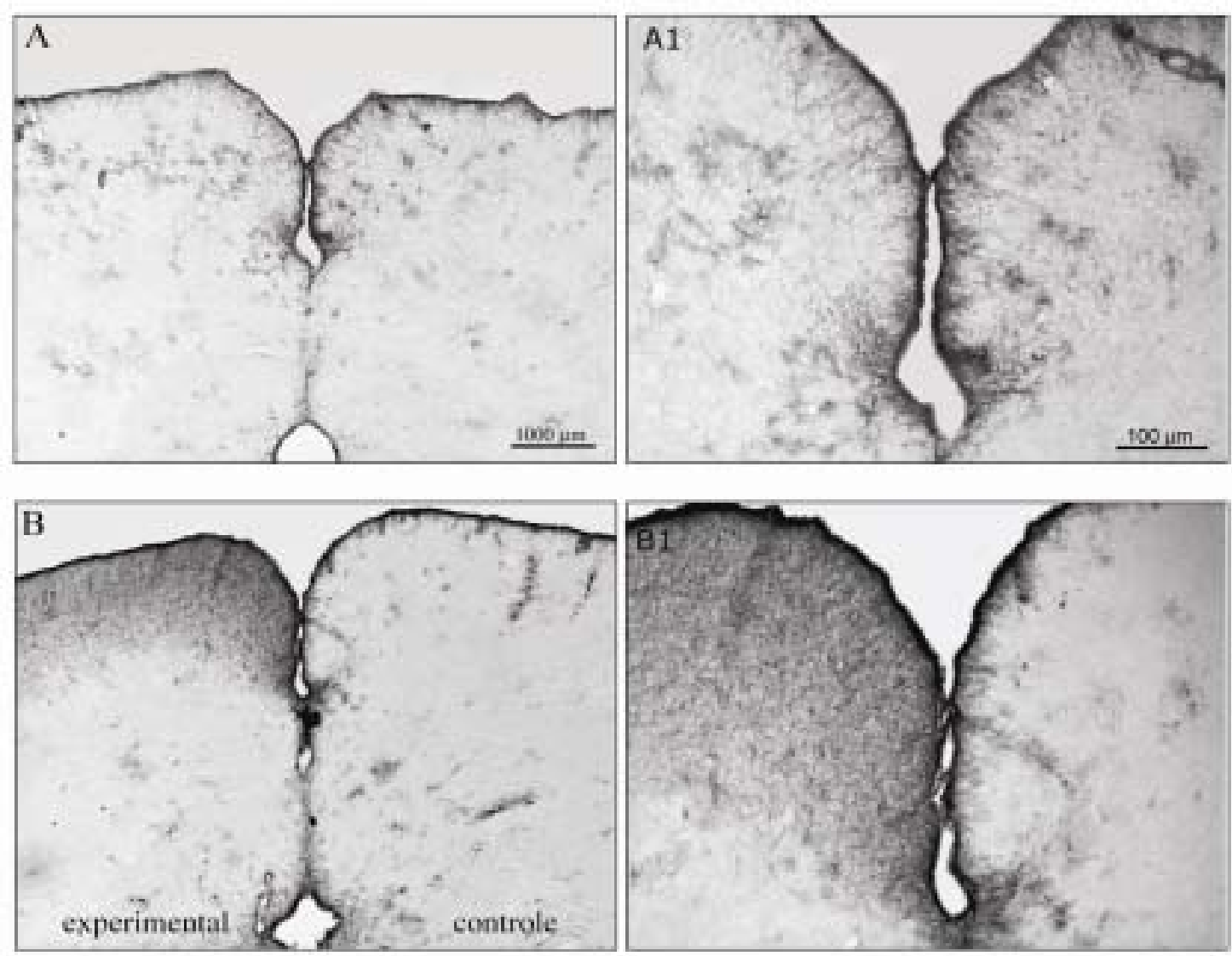

Figura 14. Imagens digitais de cortes coronais de encéfalo de rato em dois aumentos, ilustrando o padrão de marcação para GFAP no colículo superior em rato normal (A e A1), e após 15 dias de sobrevida da lesão. Os colículos à esquerda em B e B1 representam o lado experimental com aumento da imunorreatividade para astrócitos. 

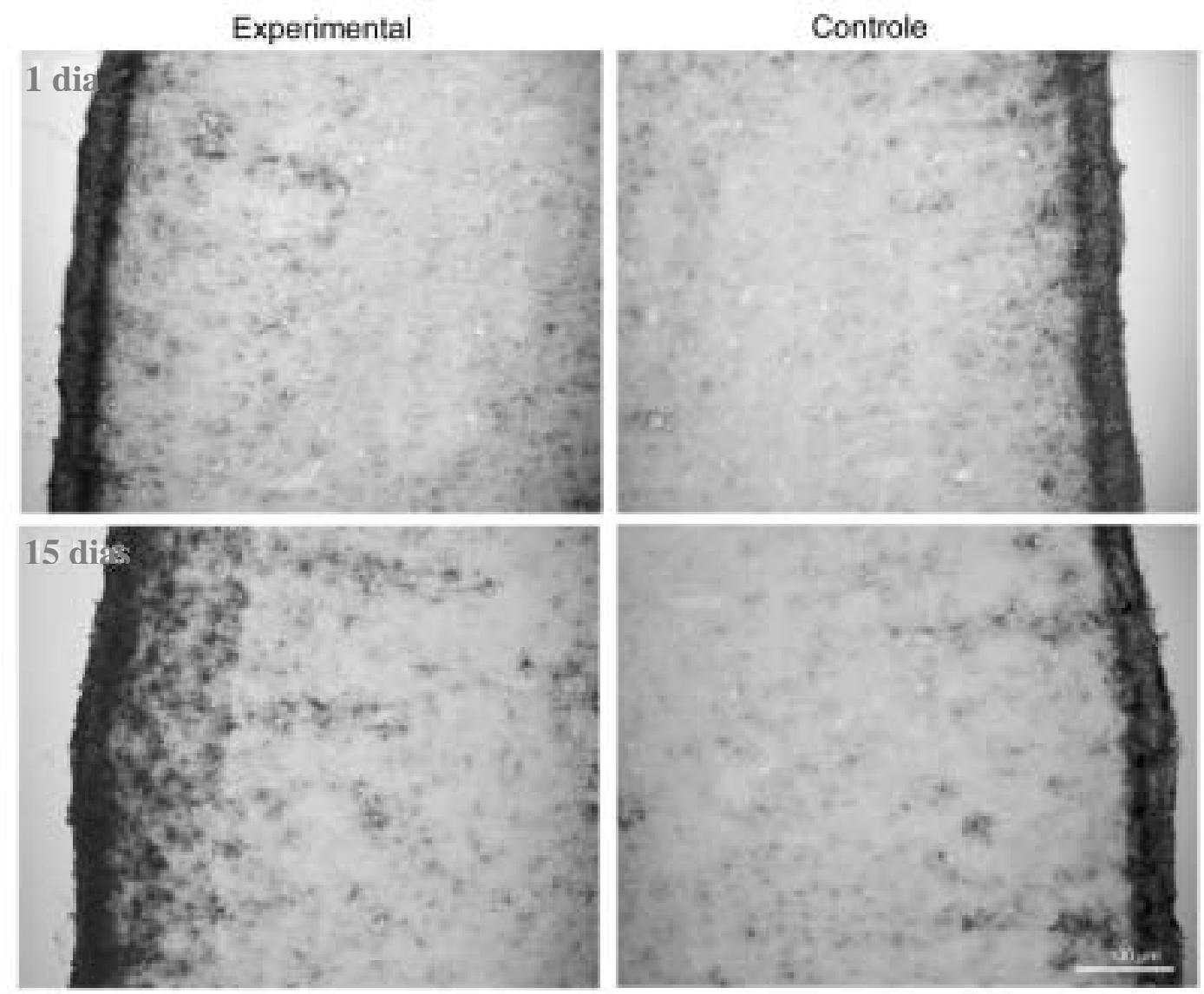

Figura 15. Imagens digitais de cortes coronais de encéfalo pintos, ilustrando o padrão de marcação para GFAP no TeO após 1 e 15 dias de sobrevida da lesão. Os TeO à esquerda representam o lado experimental com aumento da imunorreatividade para astrócitos. 


\subsection{Avaliação da eXPRESSÃo GÊNICA, PROTÉICA E dA DISTRIBUIÇÃo dOS mGluRS NO COLÍCULO SUPERIOR DE RATOS}

A técnica de reação em cadeia de polimerase (RT-PCR) foi utilizada para detectar a expressão dos mRNAs de mGluR1, mGluR2, mGluR3, mGluR5 e mGluR7 no colículo superior de ratos após os períodos de sobrevida estudados. Como controle endógeno, utilizamos o GAPDH. Nossos resultados, que estão representados nos gráficos em indução $\left(2^{X}\right)$, indicaram que houve alterações significativas nos níveis de transcrição gênica de alguns mGluRs no colículo superior após enucleação ocular (Figuras 16B, 21B, 25B e 28B).

Referente aos experimentos de immunoblotting, a análise do controle interno do experimento por meio da densitometria das bandas da $\beta$-actina não apresentou diferença estatística no colículo superior (Figura 17). A análise quantitativa dos dados confirmou que os anticorpos utilizados neste estudo contra mGluR1 (Figura 18A), mGluR5 (Figura 22A), mGluR2/3 (Figura 26A) e mGluR7 (Figura 29A) reconhecem bandas em torno de $140 \mathrm{kD}, 130 \mathrm{kD}, 100 \mathrm{kD}$ e $129 \mathrm{kD}$, respectivamente, tanto para o lado controle quanto para o experimental.

Em nossos dados pudemos observar a imunorreatividade para mGluR1 (Figura 20), mGluR5 (Figura 24), mGluR2/3 (Figura 27) em neurópila e mGluR7 (Figura 31), em pericários, nas camadas superficiais e profundas do colículo superior. Constatamos assim, a presença destes em estruturas visuais primárias.

A seguir, os resultados quantitativos e qualitativos serão mostrados seqüencialmente segundo os grupos dos receptores metabotrópicos estudados. Descreveremos inicialmente a expressão gênica e protéica, e posteriormente mostraremos os dados qualitativos de imuno-histoquímica observados no colículo superior de ratos.

\subsubsection{Grupo I}

\subsubsection{1 mGluR1}

\section{EXPRESSÃO GÊNICA}

A regressão linear das curvas geradas por diluições seriadas de cDNA, variando de 2 a 16ng de cDNA, indicou uma amplificação linear para GAPDH e mGluR1 $\left(R^{2}>0,99\right)$. 
Foi observado aumento significativo na expressão gênica de mGluR1 desde o $1^{\circ}$ dia até o 30ำ dia pós-lesão (1ำ dia 106\%; 7ํ dia: 80\%; 15 dia: 79\% e 30ํ dia: $44 \%$, todos com $\mathrm{p}<0,05$ ) (Figura 16B).

A)

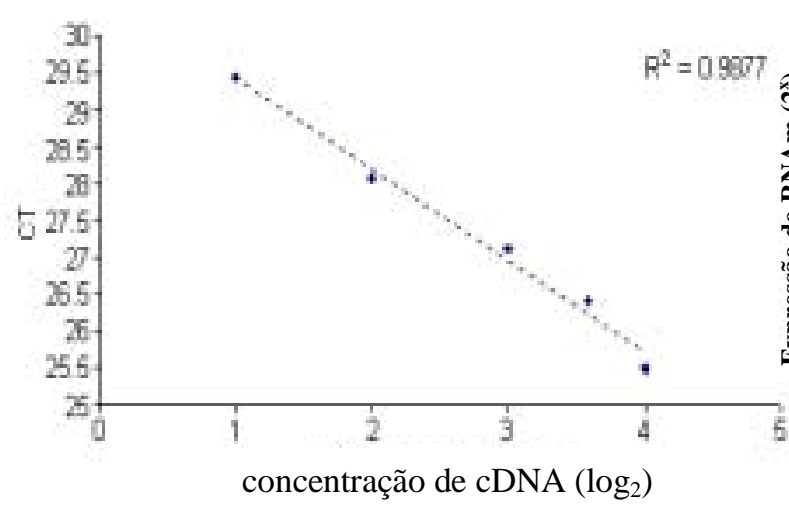

B)

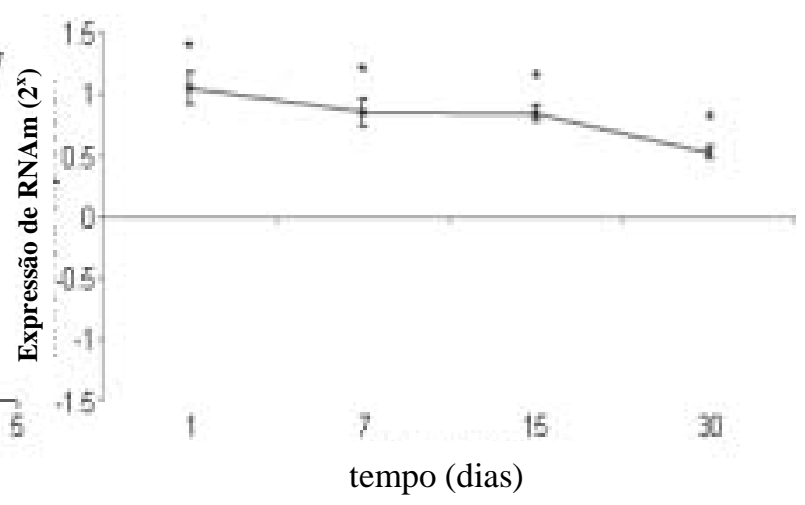

Figura 16. Expressão gênica de mGluR1 no CS após enucleação ocular pelo método de RT-PCR em tempo real. Os gráficos representam a regressão linear da curva de amplificação gerada por diluições seriais de cDNA indicando amplificação linear (A) e a variação da expressão gênica para este gene (B). ${ }^{*} \mathrm{p}<0,05$

\section{EXPRESSÃo PROTÉICA}

Os dados indicam que houve uma modulação da expressão de mGluR1 e não houve variação na expressão da $\beta$-actina entre o controle e o experimental (Figura 17).

Para mGluR1, a análise densitométrica no colículo superior não apresentou nenhuma diferença no $1^{\circ}$ dia $(17,2 \% \pm 9,00, p=0,07)$, nem no $7^{\circ}$ dia $(13,90 \% \pm 6,50$, $\mathrm{p}=0,07)$ e nem no $15^{\circ}$ dia pós-lesão $(17,90 \% \pm 5,90, p=0,17)$. Encontramos um aumento nos níveis da proteína com diferença significativa apenas no $30^{\circ}$ dia $(31,20 \% \pm 5,20, \mathrm{p}<0,05)$, Figuras $18 \mathrm{~A}$ e $\mathrm{B}$. Esses dados são semelhantes aos resultados encontrados na imuno-histoquímica no colículo superior, nos quais pudemos observar um aumento na imunorreatividade para mGluR1 no 30ำ dia póslesão. 


\section{$\beta$-Actina}
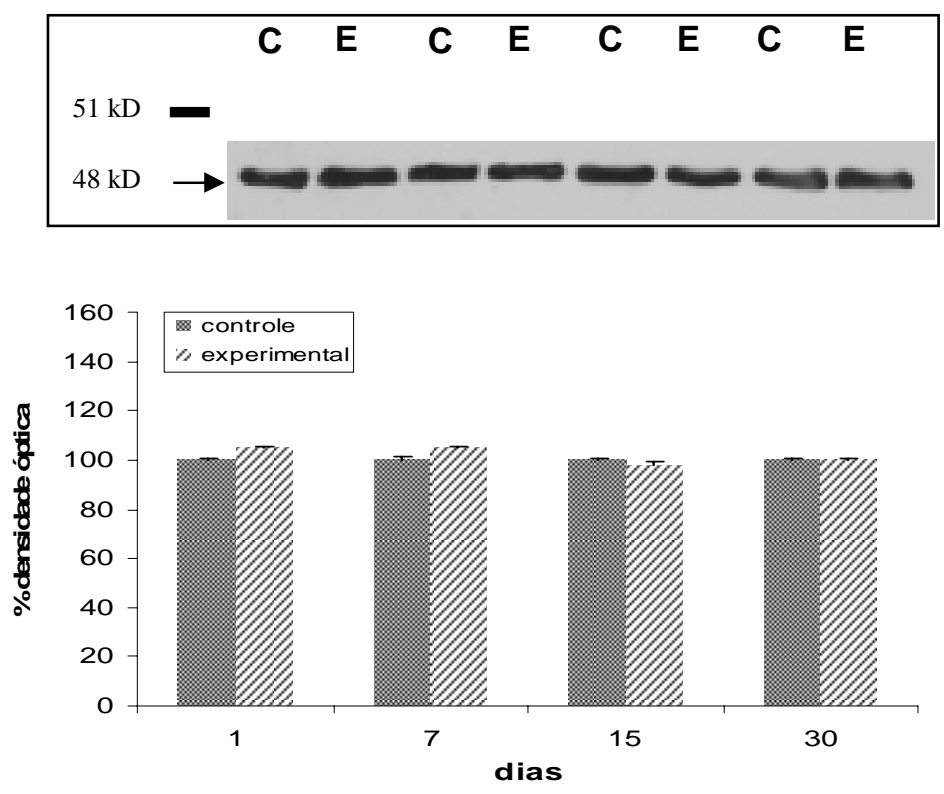

Figura 17. Análise densitométrica das bandas marcadas com anti $\beta$-actina no colículo superior. Não houve diferença significativa entre o controle e experimental.

A)

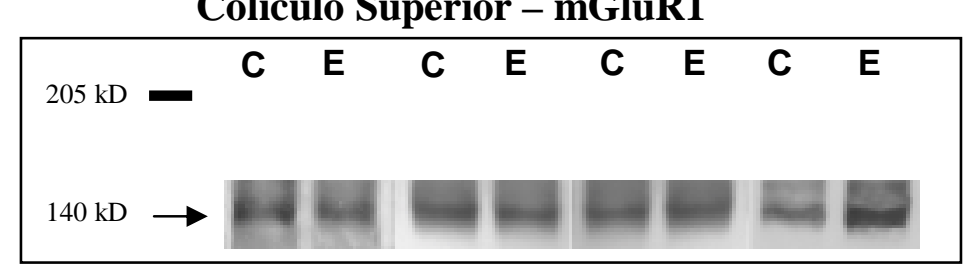

B)

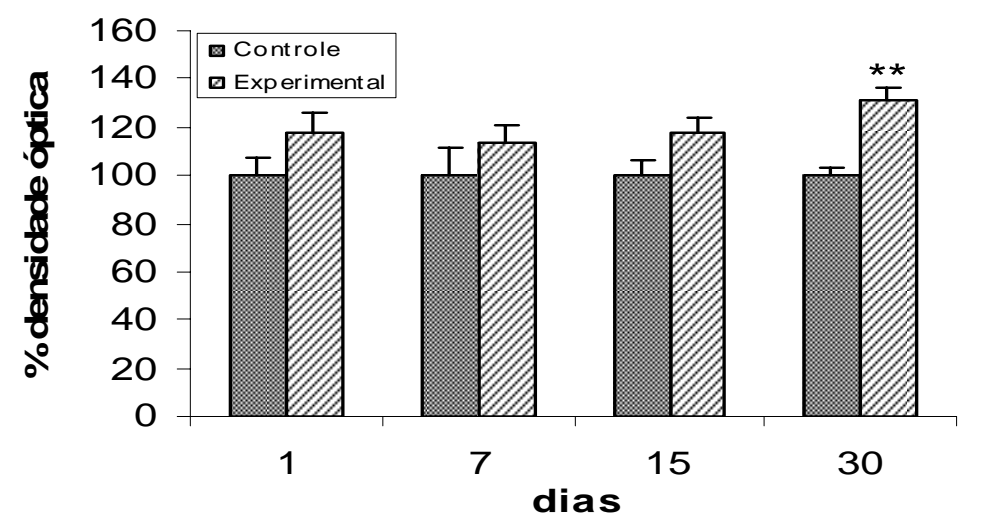

Figura 18. Efeito da enucleação ocular sobre a expressão de mGluR1 no colículo superior (A e B) de ratos nos intervalos de 1, 7, 15 e 30 dias pós-lesão. Os dados estão representados por bandas (A) e em média da densidade óptica de bandas imunorreativas (B) para mGluR1. Os gráficos representam a porcentagem da densidade óptica no grupo experimental em relação ao controle, tomado como $100 \%$. $* * \mathrm{p}<0,05$. 


\section{IMUNORREATIVIDADE}

A expressão de mGluR1 após enucleação ocular foi alterada no $15^{\circ}$ e $30^{\circ}$ dias pós-lesão no lado contralateral (experimental) do colículo superior (Figura 19). A análise de densidade óptica da imunorreatividade para mGluRs mostrou que para mGluR1 nas camadas Zo e SuG do lado contralateral do colículo superior a densidade permaneceu igual no $1^{\circ}$ dia pós-lesão $(3,98 \% \pm 22,18, p=0,57)$ e no $7^{\circ}$ dia $(3,46 \% \pm 31,20, p=0,67)$, apresentando um aumento com diferença estatisticamente significativa no $15^{\circ}$ pós-lesão $\left(16,03 \% \pm 13,05\right.$, p<0,0001) e $30^{\circ}$ dia $(22,78 \% \pm 29,78$, $\mathrm{p}<0,0001$ ) comparado ao controle (Figura 19).

A análise da expressão de mGluR1 revelada por imunoperoxidase em cortes coronais de encéfalos de ratos mostrou que há apenas neurópila marcada nas camadas Zo e SuG, neurópila (Figuras 20A) e pericários na camada Op (Figura 20B), como também nas camadas mais profundas, tais como a InG, camada nãovisual do colículo superior. A Figura $20 \mathrm{C}$ mostra o aumento da imunorreatividade para mGluR1 nas camadas superficiais do colículo superior.

\section{mGluR1}

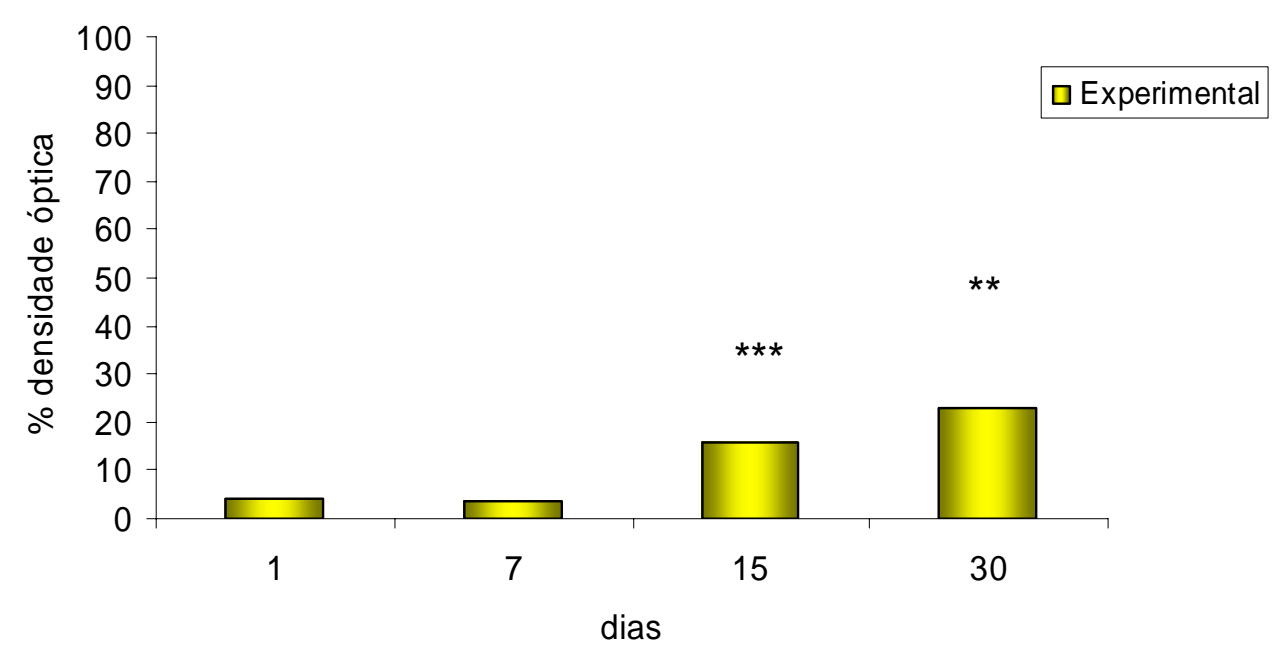

Figura 19. Gráfico representando a porcentagem da densidade óptica para mGluR1 nas camadas superficiais do CS, após diferentes tempos de sobrevida de lesões: 1, 7, 15 e 30 dias. Para a análise comparativa entre o animal controle e o experimental foi considerada referencial o eixo da abscissa sendo $100 \%$. ***p $<0,0001, * * \mathrm{p}<0,05$. 

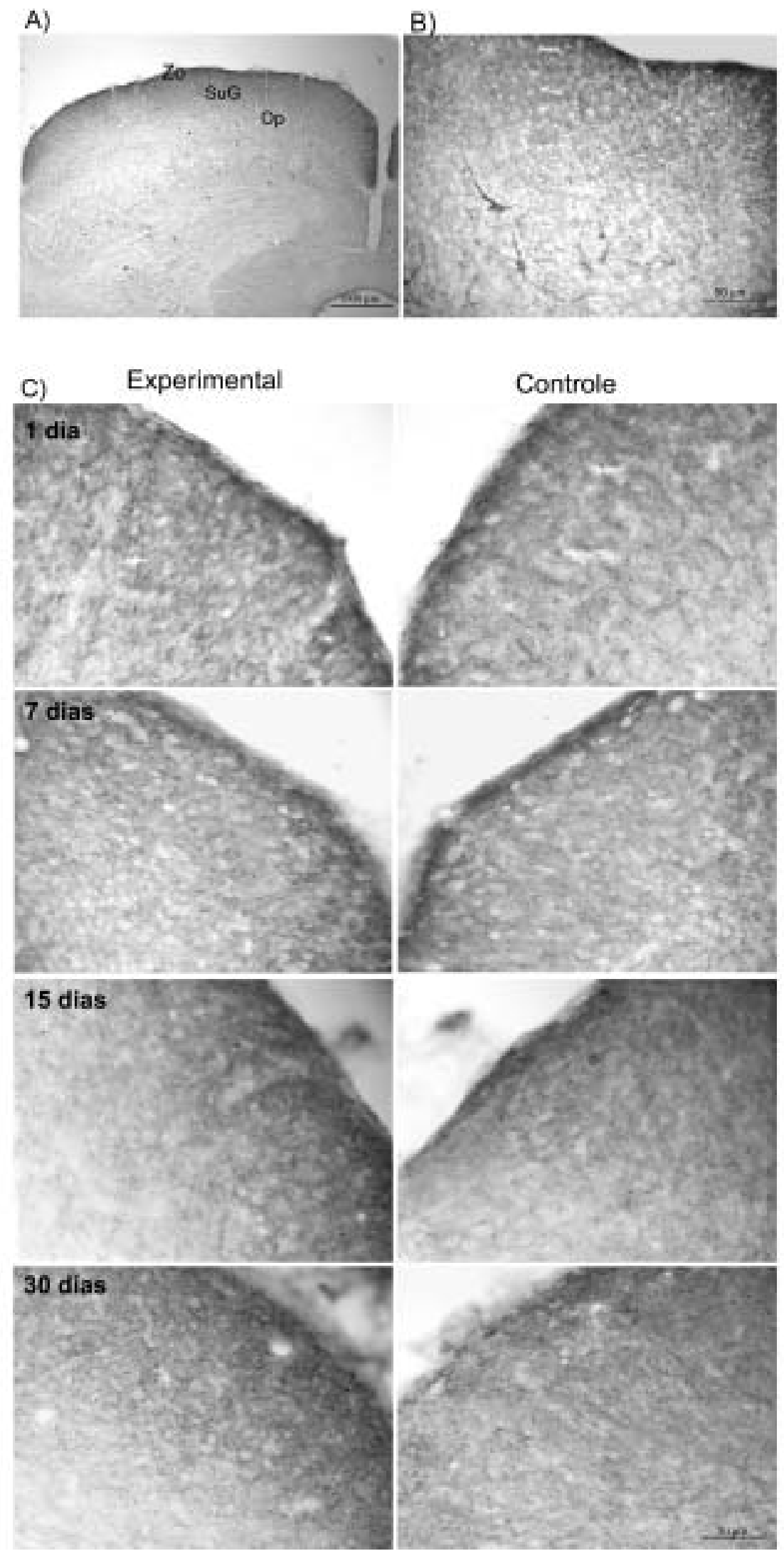

Figura 20. Imagens digitais de cortes coronais de encéfalo de ratos, ilustrando o padrão de marcação para o mGluR1 no colículo superior sem lesão (A), pericários e neurópilas imunorreativas (B) e após diferentes tempos de sobrevida de lesões: 1, 7, 15 e 30 dias (C). O colículo à esquerda de cada imagem representa o lado experimental, apresentando aumento da imunorreatividade para mGluR1. 


\subsubsection{2 mGluR5}

\section{EXPRESSÃO GÊNICA}

Para o outro subtipo do grupo I, a regressão linear das curvas geradas por diluições seriadas de cDNA indicou uma amplificação linear para GAPDH e mGluR5 $\left(R^{2}>099\right)$, Figura 21A. A expressão gênica aumentou apenas no $30^{\circ}$ dia pós-lesão $(80 \%, p<0,05)$ Figura 21B.

A)

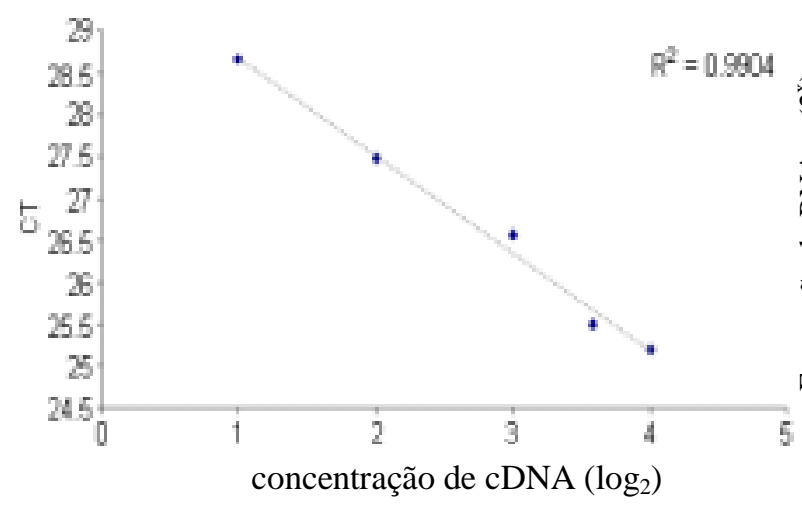

B)

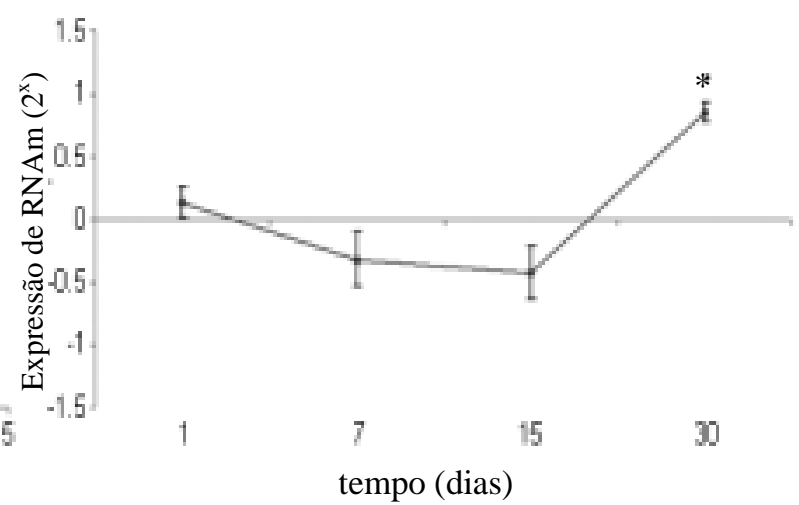

Figura 21. Expressão gênica do mGluR5 no CS após enucleação ocular pelo método de RT-PCR em tempo real. Os gráficos representam a regressão linear da curva de amplificação gerada por diluições seriais de cDNA indicando amplificação linear (A) e a variação da expressão gênica para este gene (B). $* \mathrm{p}<0,05$

\section{EXPRESSÃo ProtéICA}

Nos resultados para mGluR5, também pertencente ao grupo I de receptores metabotrópicos, observamos uma aumento com diferença significativa no $30^{\circ}$ dia pós-lesão $(31,60 \% \pm 3,10, p<0,05)$ no colículo superior; para os outros dias os resultados foram: no $1^{\circ}$ dia pós-lesão cerca de $2 \%(1,70 \% \pm 6,00, p=0,71)$; no $7^{\circ}$ dia, $11 \%(11,30 \% \pm 7,70, p=0,19)$ e no $15 \%$ dia, $15 \%(14,70 \% \pm 10,55, p=0,13)$ acima do controle, mas sem diferença significativa (Figuras 22A e B). 
B)
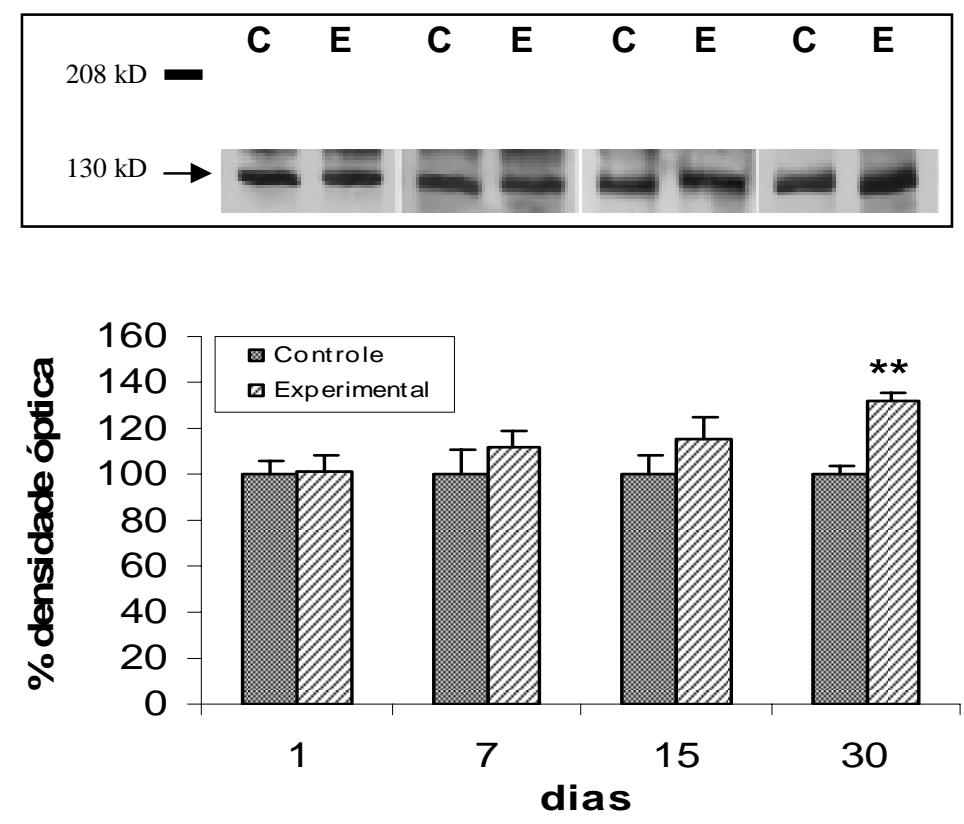

Figura 22. Efeito da enucleação ocular sobre a expressão de mGluR5 no colículo superior (A e B) de rato nos intervalos de 1, 7, 15 e 30 dias pós-lesão. Os dados estão representados por bandas (A) e em média da densidade óptica de bandas imunorreativas (B) para mGluR5. Os gráficos representam a porcentagem da densidade óptica no grupo experimental em relação ao controle, tomado como $100 \%$. ** $\mathrm{p}<0,05$.

\section{IMUNORREATIVIDADE}

Em uma análise da densidade imunorreativa para mGluR5, observamos um aumento com diferença estatisticamente significativa da imunorreatividade na neurópila na camada Zo a partir do $7^{0}$ dia pós-lesão. $\mathrm{Na}$ análise por densidade óptica, a imunorreatividade para o $1^{\circ}$ dia pós-lesão foi de $10 \%(10,14 \pm 24,19$, $\mathrm{p}=0,24)$ sem diferir do controle, mas a partir do $7^{\circ}$ dia 0 aumento foi de aproximadamente $20 \%(19,50 \pm 17,29, p<0,05)$, no $15^{\circ}$ dia foi de $32 \%(31,51 \% \pm$ $29,26, p<0,05)$ e no $30^{\circ}$ dia foi de $54 \%(53,76 \% \pm 16,59, p<0001)$ (Figura 23 ).

$A$ imunorreatividade ficou restrita à neurópila da camada Zo e em menor grau de imunorreatividade na camada SuG (Figura $24 \mathrm{~B} \mathrm{e} \mathrm{C}$ ). Pode-se observar neurópila marcada em um maior aumento na camada Zo, Figura 24 B e os aumentos da imunorreatividade após a encucleação ocular para esse receptor na Figura 24C. 


\section{mGluR5}

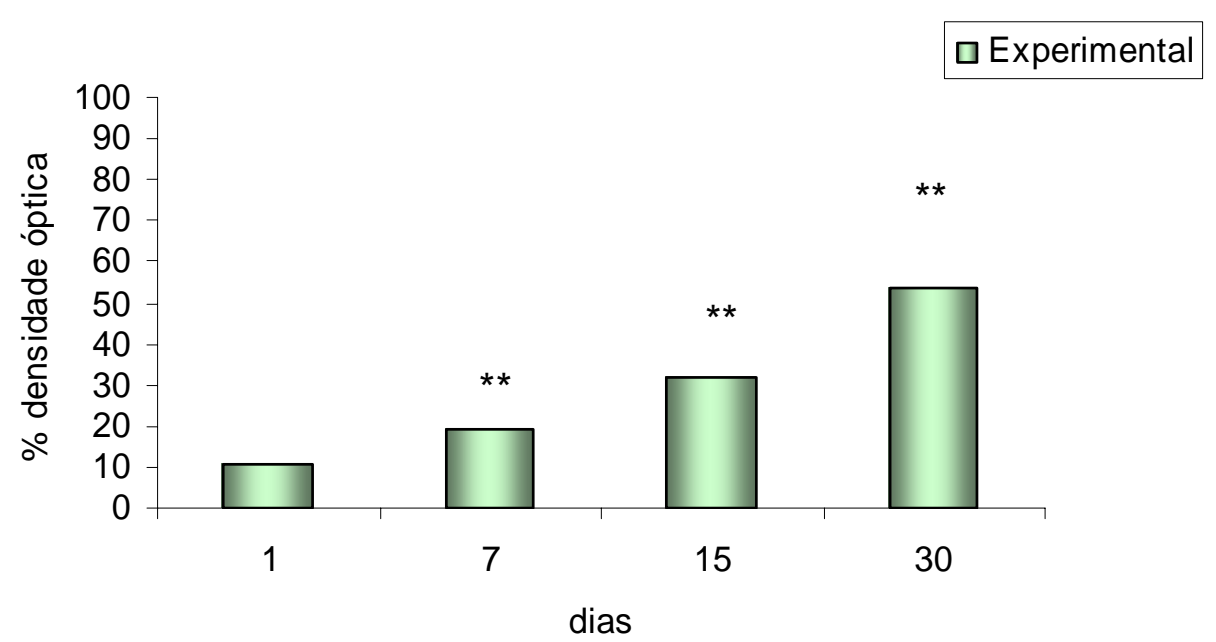

Figura 23. Gráfico representando a porcentagem da densidade óptica para mGluR5 nas camadas superficiais do CS, após diferentes tempos de sobrevida de lesões: 1, 7, 15 e 30 dias. Para a análise comparativa entre o animal controle e o experimental foi considerada referencial o eixo da abscissa sendo $100 \%$. ** $<<0,05$. 

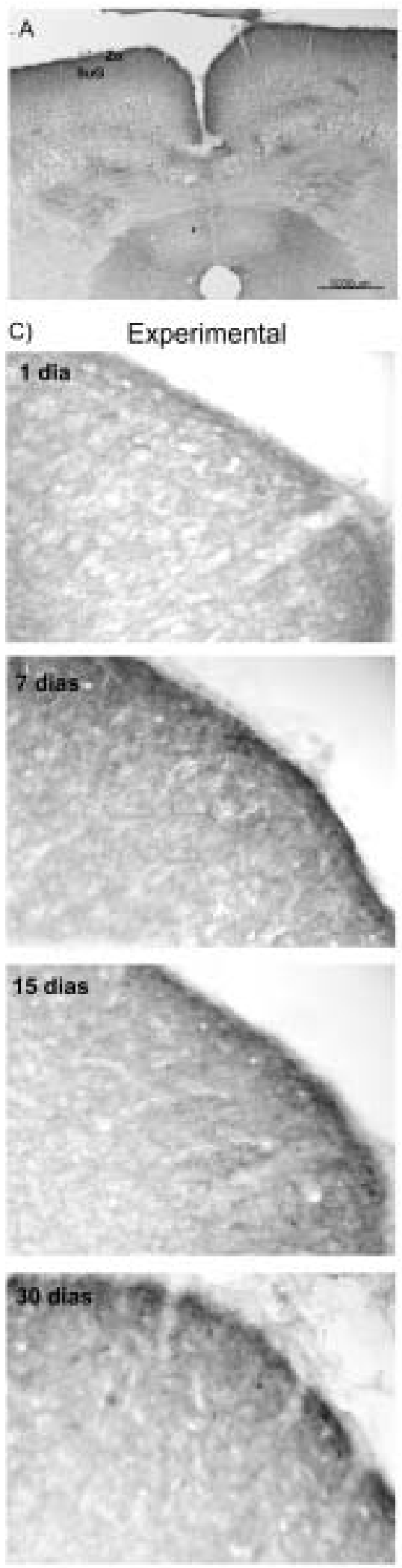

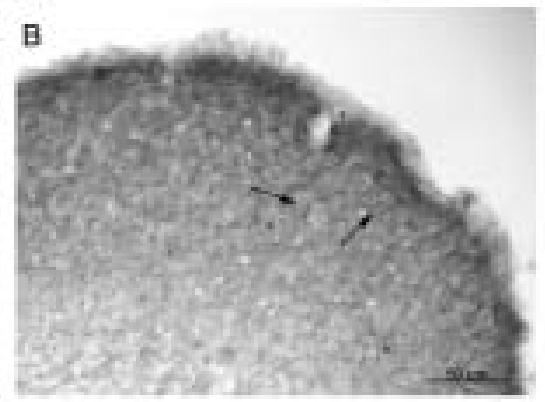

\section{Controle}
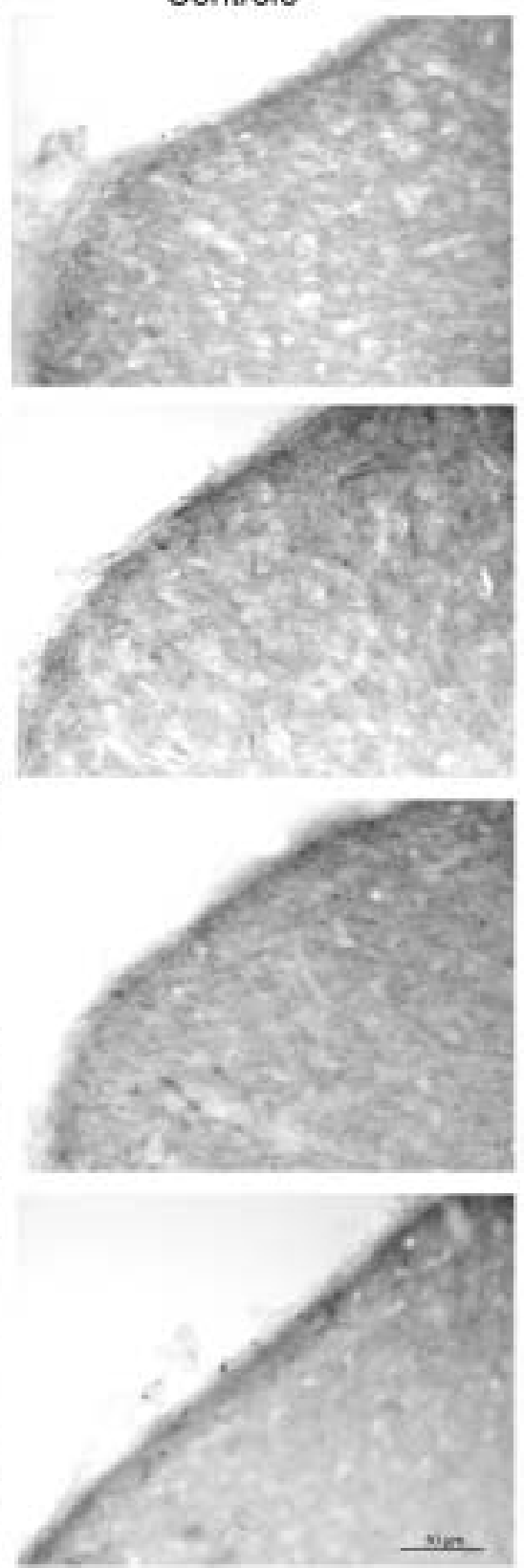

Figura 24. Imagens digitais de cortes coronais de encéfalo de ratos, ilustrando o padrão de marcação para o mGluR5 no colículo superior sem lesão (A e B) e após diferentes tempos de sobrevida de lesões: 1,7, 15 e 30 dias (C). O colículo à esquerda de cada imagem representa o lado experimental, apresentando o aumento da imunorreatividade para mGluR5. As setas indicam neurópila imunorreativa na camada Zo e SuG. 


\subsubsection{Grupo II}

\subsubsection{1 mGluR2/3}

\section{EXPRESSÃO GÊNICA}

A regressão linear das curvas geradas por diluições seriadas de cDNA indicou uma amplificação linear para GAPDH, mGluR2 $\left(R^{2}>0,99\right)$ e mGluR3 $\left(R^{2}>0,94\right)$.

No caso da expressão gênica observamos os genes separadamente; para o subtipo mGluR2 os níveis de transcrição gênica não foram alterados nos referentes dias após a lesão (Figura 25A). Em contrapartida, para o mGluR3 houve uma redução nos níveis apenas no $1^{\circ}$ dia $(37 \%, p<0,05)$ e $7^{\circ}$ dia pós-lesão $(47 \%, p<0,05)$ quando comparado ao controle (Figura 25B).

A)

\section{mGluR2}

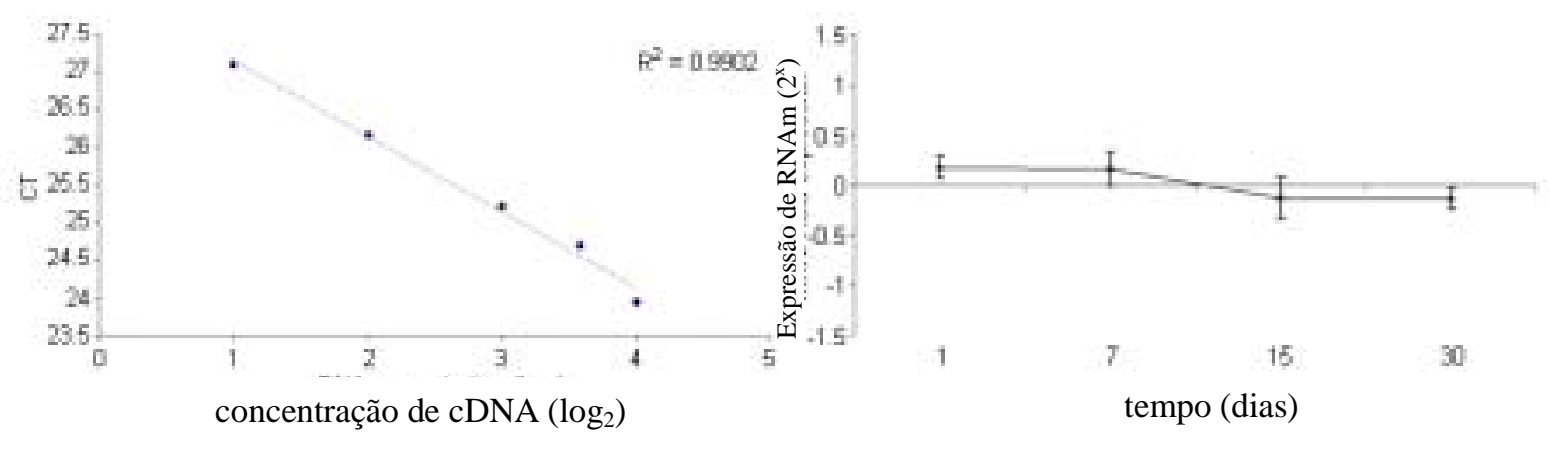

B)

\section{mGluR3}
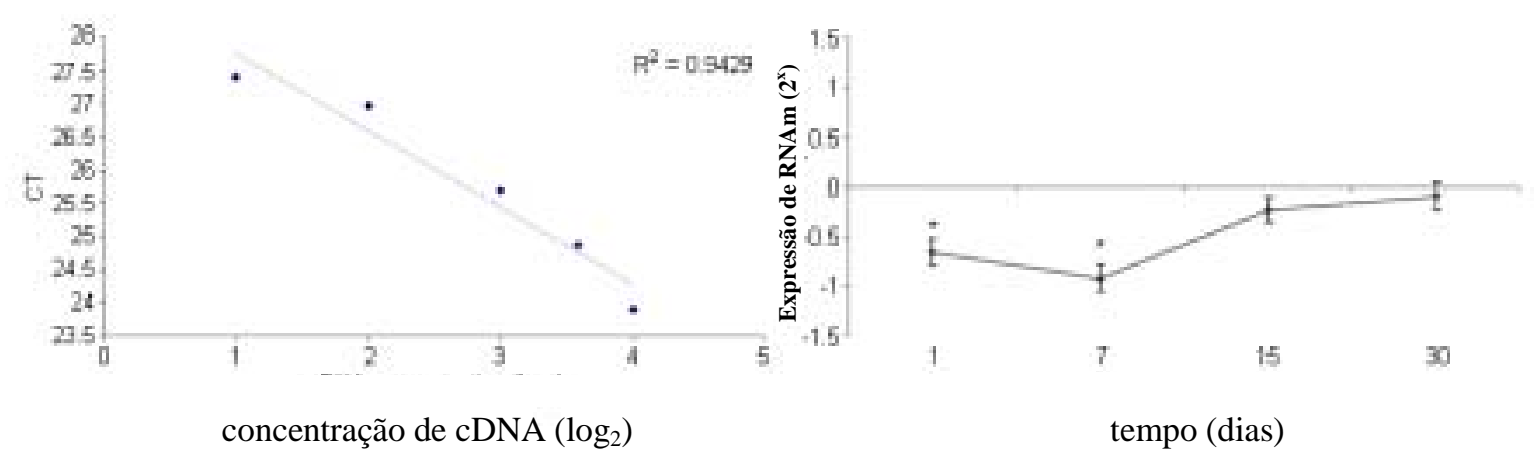

Figura 25. Expressão gênica de mGluR2 (A) e mGluR3 (B) no CS após enucleação ocular pelo método de RT-PCR em tempo real. Os gráficos representam a regressão linear da curva de amplificação gerada por diluições seriais de cDNA indicando amplificação linear e a variação da expressão gênica para estes genes. ${ }^{*} \mathrm{p}<0,05$ 


\section{EXPRESSÃO PROTÉICA}

Para mGluR2/3 não houve diferença estatística na expressão protéica nos dias avaliados, nem no colículo superior, nem no complexo geniculado lateral, confirmando os resultados da imuno-histoquímica. Os dados do colículo superior foram: no $1^{\circ}$ dia, $4,10 \% \pm 6,70, p=0,63 ; 7^{\circ}$ dia, $4,50 \% \pm 8,50, p=0,50$ a menos que o controle e no $15^{\circ}$ dia, $13,00 \% \pm 7,50, p=0,35$ e no $30^{\circ}$ dia pós-lesão, $6,40 \% \pm 9,00$, $\mathrm{p}=0,80$ (Figuras 26A e B).

\section{Colículo Superior - mGluR2/3}

A)

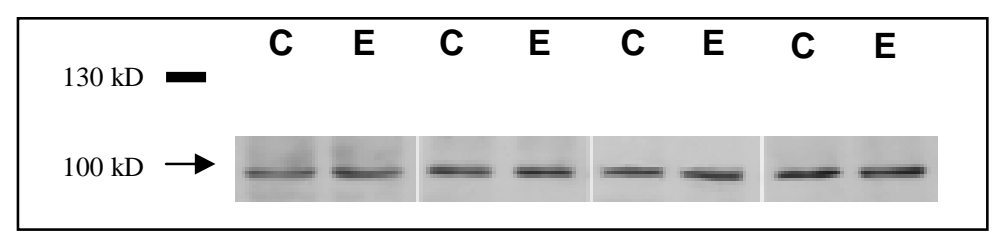

B)

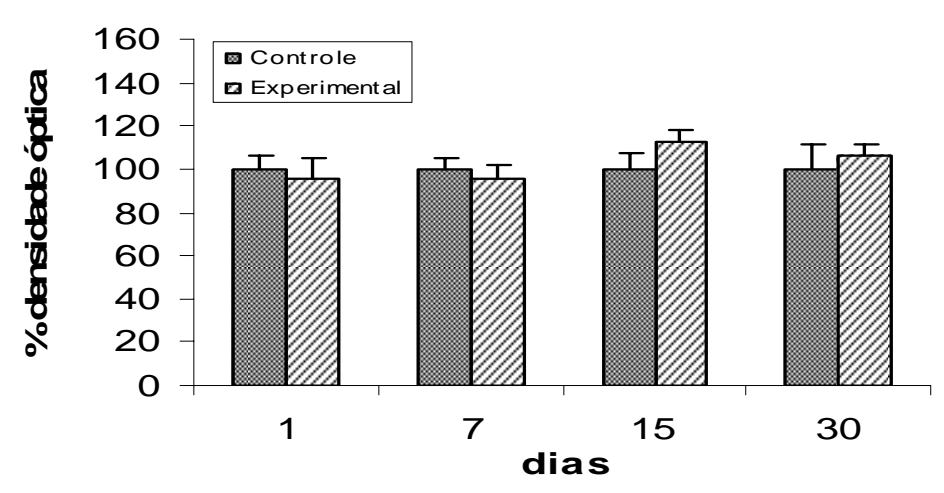

Figura 26. Efeito da enucleação ocular sobre a expressão de mGluR2/3 no colículo superior (A e B) de ratos nos intervalos de 1, 7, 15 e 30 dias pós-lesão. Os dados estão representados por bandas (A) e em média da densidade óptica de bandas (B) para mGluR2/3. Os gráficos representam a porcentagem da densidade óptica no grupo experimental em relação ao controle, tomado como $100 \%$.

\section{IMUNORREATIVIDADE}

O padrão de marcação para mGluR2/3 é visualizado na neurópila das camadas Zo, SuG e Op do colículo superior (Figura 27A e B). O interessante é que para este receptor pudemos observar também aglomerados de neurópila na camada SuG, como ilustrado na Figura 26B.

Quando analisamos a imunorreatividade para mGluR2/3, a expressão não apresentou diferença em neurópila nas camadas do CS nos tempos de sobrevida estudados (Figura 27C). 

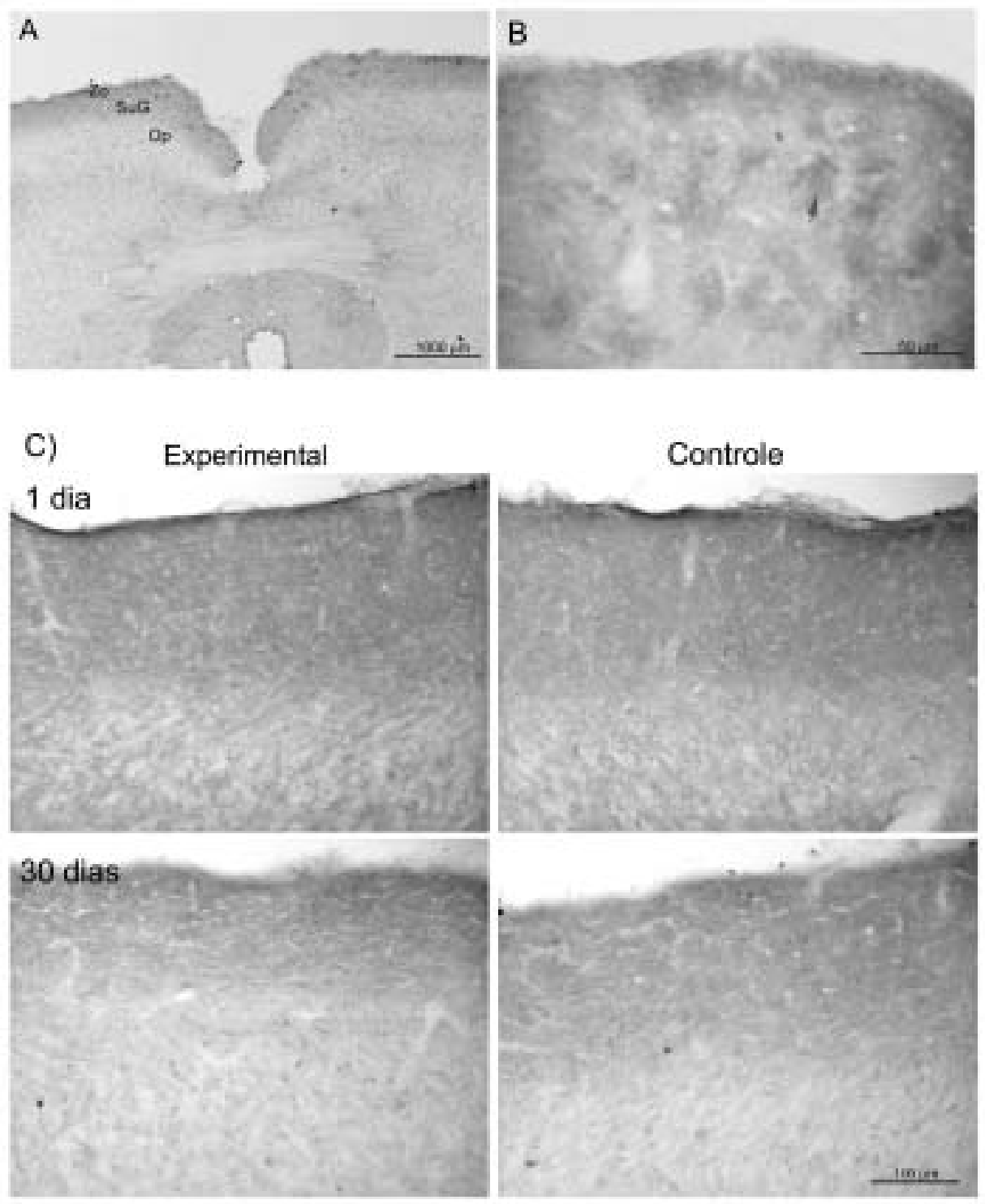

Figura 27. Imagens digitais de cortes coronais de encéfalo de ratos, ilustrando o padrão de marcação para mGluR2/3 no colículo superior sem lesão (A e B) e após diferentes tempos de sobrevida de lesões: 1 e 30 dias (C). O colículo à esquerda de cada imagem representa o lado experimental, não apresentando diferença da imunorreatividade para mGluR2/3. As setas na figura $B$ indicam os aglomerados de neurópila na SuG. 


\subsubsection{Grupo III}

\subsubsection{1 mGluR7}

\section{EXPRESSÃO GÊNICA}

A regressão linear das curvas geradas por diluições seriadas de cDNA indicou uma amplificação linear para GAPDH e mGluR7 $\left(R^{2}>0,99\right)$, Figura $28 A$. Para esse gene, houve aumento significativo do mGluR7 logo no 1ำ dia pós-lesão (596\%, $p<0,05)$. Esse aumento persistiu no $7^{\circ}$ dia, com níveis gênicos de $416 \%$ em relação ao controle. Os níveis normalizaram-se no $15^{\circ}$ e $30^{\circ}$ dias pós-lesão (Figura 28B).
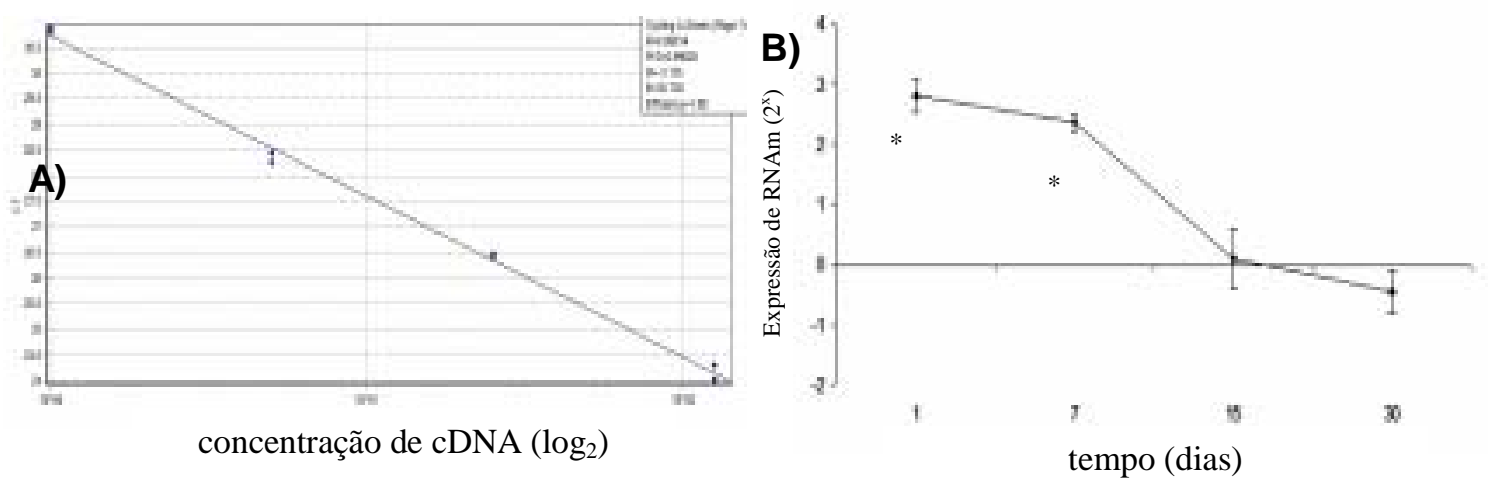

Figura 28. Expressão gênica de mGluR7 no CS após enucleação ocular pelo método de RTPCR em tempo real. Os gráficos representam a regressão linear da curva de amplificação gerada por diluições seriais de cDNA indicando amplificação linear (A) e a variação da expressão gênica para este gene (B). ${ }^{*} \mathrm{p}<0,05$

\section{EXPRESSÃO PROTÉICA}

Da mesma forma, encontramos um aumento significativo na expressão protéica para mGluR7 no $1^{\circ}$ dia $(27,10 \% \pm 4,00, p<0,05)$. Esse aumento foi mais expressivo no $7^{\circ}$ dia $(36,00 \% \pm 6,90, p<0,05)$, igualando-se aos níveis do controle no $15^{\circ}$ dia pós-lesão $(13,00 \% \pm 14,40, p=0,50)$ e no $30^{\circ}$ dia pós-lesão $(9,20 \% \pm 12,00$, $\mathrm{p}=0,66$ ); Figuras $29 \mathrm{~A}$ e $\mathrm{B}$.

Os resultados estão representados em gráficos para cada dia analisado e ilustrados por imagens das bandas. A densidade média foi sempre considerada $100 \%$. 


\section{Colículo Superior - mGluR7}

A)

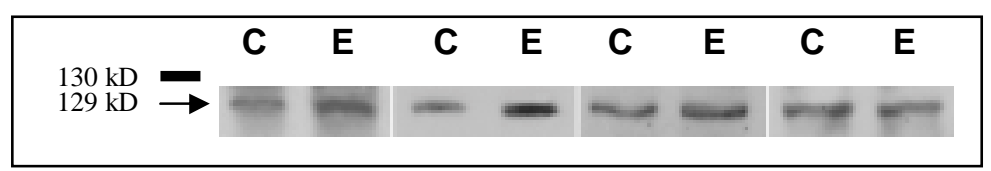

B)

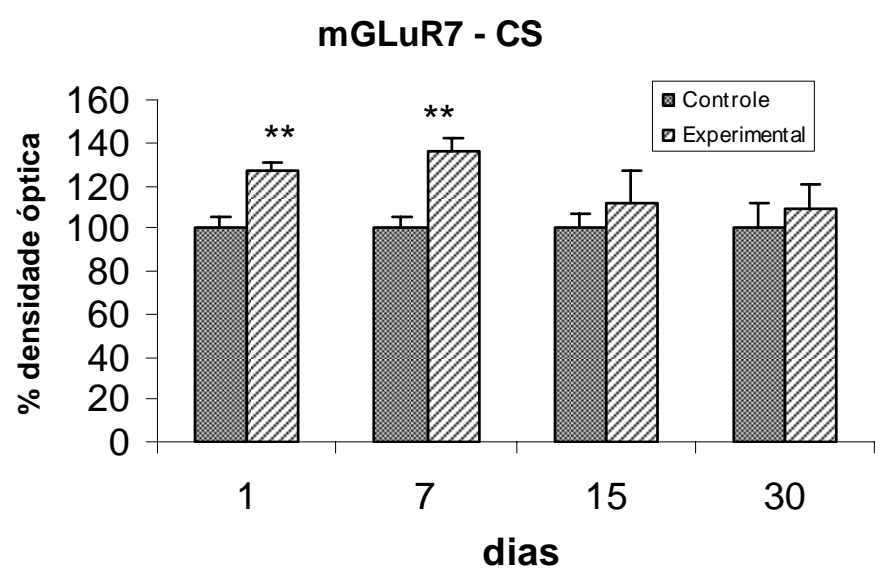

Figura 29. Efeito da enucleação ocular sobre a expressão de mGluR7 no colículo superior (A e B) de ratos nos intervalos de 1, 7,15 e 30 dias pós-lesão. Os dados estão representados por bandas (A) e em média da densidade óptica de bandas (B) para mGluR7. Os gráficos representam a porcentagem da densidade óptica no grupo experimental em relação ao controle, tomado como $100 \%$.

\section{IMUNORREATIVIDADE}

Para mGluR7 observamos um aumento do número de pericários e imunorreatividade na neurópila desde $01^{\circ}$ dia pós-lesão, voltando os níveis normais no $30^{\circ}$ dia pós-lesão (Figura 30 e $31 \mathrm{C}$ ). A quantificação do número de pericários imunorreativos nas camadas Zo e SuG mostrou diferença estatística para o $1^{\circ}, 7^{\circ} \mathrm{e}$ $15^{\circ}$ dias pós-lesão com aumento de aproximadamente $38 \%(38,06 \% \pm 0,17$, $p<0,0001), 72 \%(72,00 \% \pm 0,13, p<0,0001)$ e $54 \%(54,38 \% \pm 0,26, p<0,0001)$, respectivamente. No $30^{\circ}$ dia pós-lesão, a porcentagem do número de pericários foi de $5,4 \%(5,39 \% \pm 0,14, p=0,10)$ a menos em relação ao controle, assim não apresentando diferença (Figura 30).

Para mGluR7, observamos neurópila marcada na camada Zo, pericários e neurópila imunorreativos na camada SuG e Op, como também na InG (Figura 31B). A marcação para este receptor pode ser observada em regiões margeando a 
membrana citoplasmática dos pericários. $\mathrm{O}$ aumento do número de células no $1^{\circ}$, $7^{\circ}$ e $1^{\circ}$ dias de sobrevida pode ser observado na Figura 31C. Não observamos alterações em camadas profundas do CS.

\section{mGluR7}

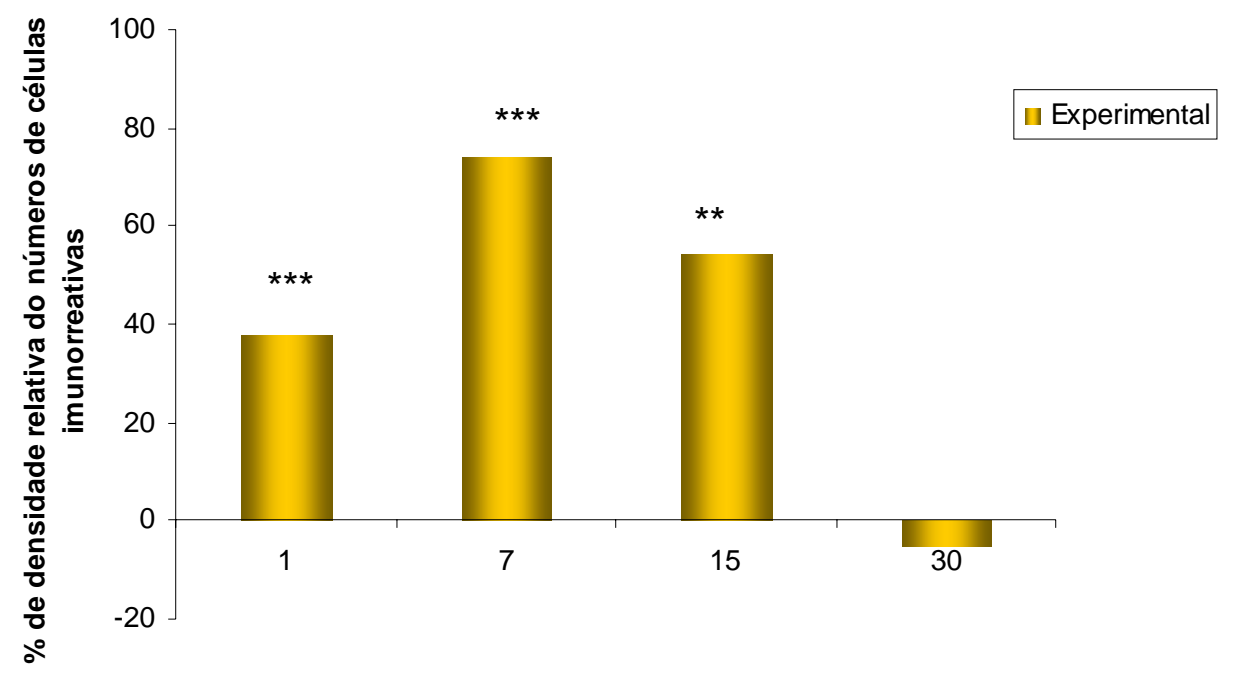

Figura 30. Gráfico representando a porcentagem da densidade relativa do número de células imunorreativas para mGluR7 nas camadas superficiais do CS, após diferentes tempos de sobrevida de lesões: $1,7,15$ e 30 dias. Para a análise comparativa entre o animal controle e o experimental foi considerada referencial o eixo das abscissas sendo $100 \%$. *** $p<0,0001$, $* * \mathrm{p}<0,05$. 

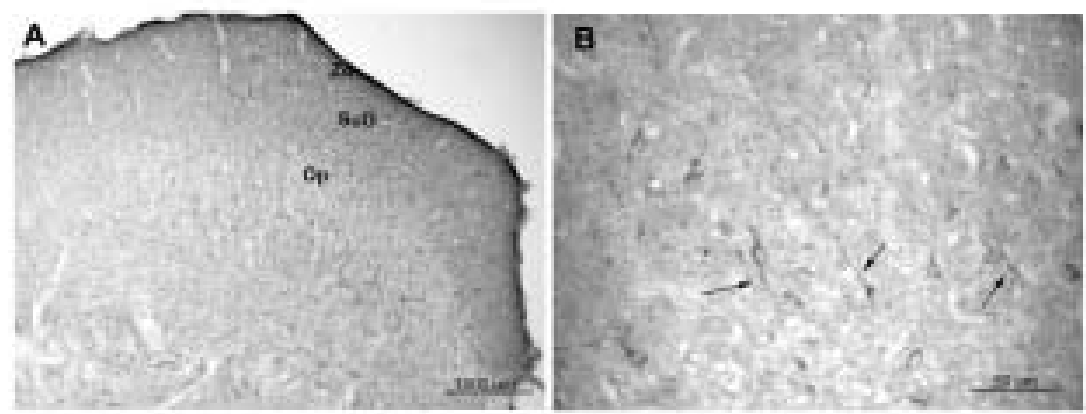

c)
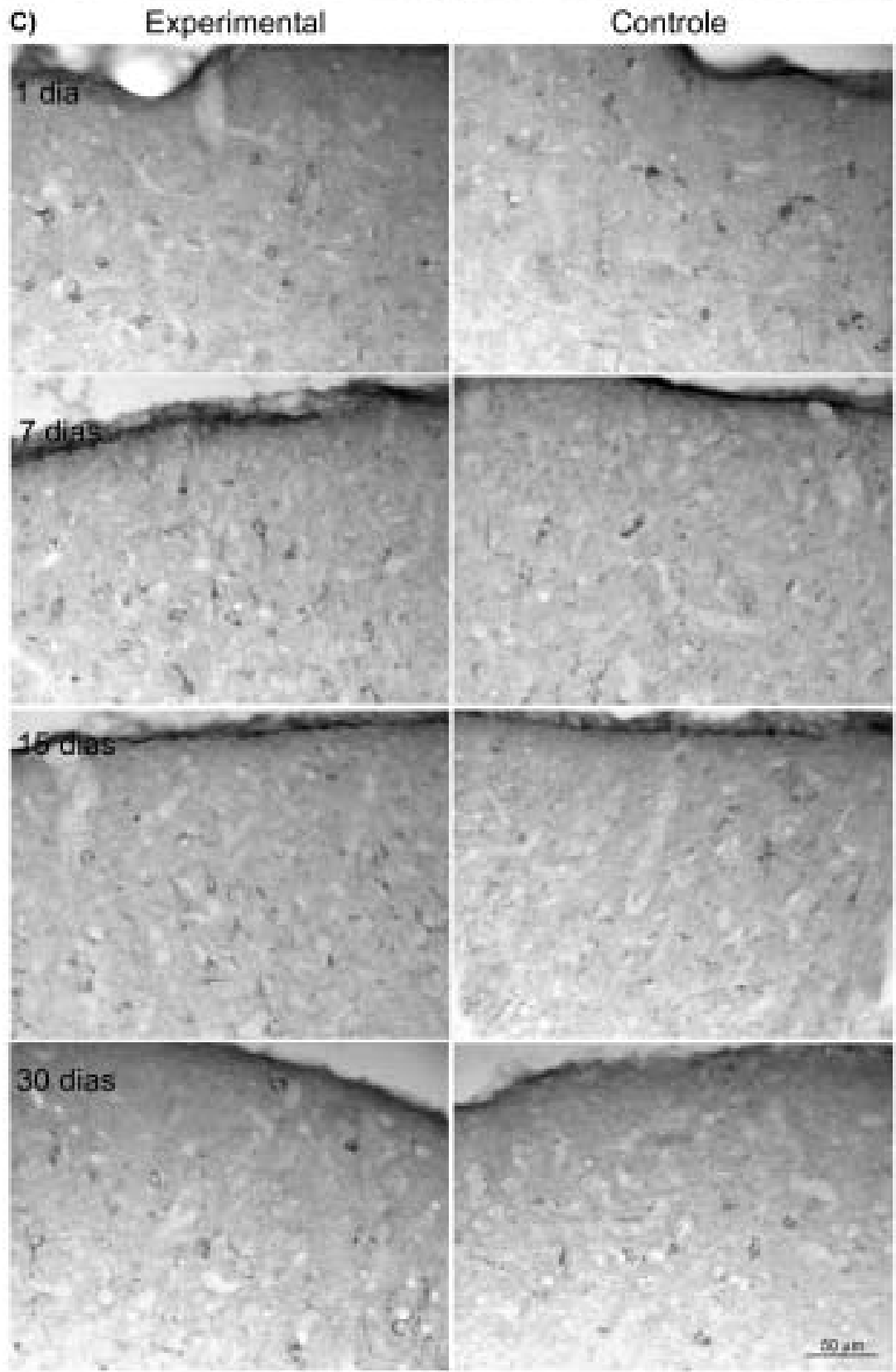

Figura 31. Imagens digitais de cortes coronais de encéfalo de ratos, ilustrando o padrão de marcação para mGluR7 no colículo superior sem lesão (A e B) e após diferentes tempos de sobrevida de lesões: $1,7,15$ e 30 dias. $\mathrm{O}$ colículo à esquerda de cada imagem representa o lado experimental, apresentando o aumento da imunorreatividade para mGluR7. As setas indicam pericários imunorreativos na camada $\mathrm{Zo} \mathrm{e} \mathrm{SuG}$. 


\subsection{RESUMO DOS RESULTADOS PARA O COLÍCULO SUPERIOR}

Tabela 3. Resultados resumidos das análises da expressão gênica, protéica e da imunorreatividade para mGluR1, mGluR5, mGluR2/3 e mGluR7 no colículo superior de ratos no $1^{\circ}, 7^{\circ}, 15^{\circ}$ e $30^{\circ}$ dias após a enucleação ocular.

\section{Colículo Superior}

\begin{tabular}{|c|c|c|c|c|c|c|c|c|c|c|c|c|}
\hline \multirow[t]{2}{*}{ Receptores } & \multicolumn{3}{|c|}{$1 \mathrm{dia}$} & \multicolumn{3}{|c|}{7 dias } & \multicolumn{3}{|c|}{15 dias } & \multicolumn{3}{|c|}{30 dias } \\
\hline & RT & B & Ir & RT & B & Ir & RT & B & Ir & RT & B & Ir \\
\hline mGluR1 & + & $=$ & $=$ & + & $=$ & $=$ & + & $=$ & + & + & + & + \\
\hline mGluR5 & $=$ & $=$ & $=$ & $=$ & $=$ & + & $=$ & $=$ & + & + & + & + \\
\hline mGluR2/3 & $=/-$ & $=$ & $=$ & $=/-$ & $=$ & $=$ & $=/=$ & $=$ & $=$ & $=/=$ & $=$ & $=$ \\
\hline mGluR7 & + & + & + & + & + & + & $=$ & $=$ & + & $=$ & $=$ & $=$ \\
\hline
\end{tabular}

$R T=R T-P C R ; B=$ immunoblotting; Ir=imunorreatividade

= não há diferença entre o colículo experimental e controle; + maior intensidade de marcação na neurópila no lado experimental e no caso do mGluR7 maior número de células. 


\subsection{AVALIAÇÃO DA EXPRESSÃo PROTÉICA E dA DISTRIBUIÇÃO dOS mGluRs No Núcleo Geniculado LATERAL de Ratos}

A análise quantitativa dos dados com os experimentos de immunoblotting também confirmou que os anticorpos utilizados neste estudo contra mGluR1 (Figura 32), mGluR5 (Figura 35), mGluR2/3 (Figura 38) e mGluR7 (Figura 41) reconhecem bandas em torno de $140 \mathrm{kD}, 130 \mathrm{kD}, 100 \mathrm{kD}$ e $129 \mathrm{kD}$, respectivamente, tanto para 0 lado controle quanto para o experimental.

Os resultados mostraram que há imunorreatividade para mGluR1 (Figuras 33 e 34), mGluR5 (Figuras 36 e 37), mGluR2/3 (Figuras 39 e 40) em neurópila e mGluR7 (Figuras 42 e 43), em pericários, no núcleo geniculado lateral. Constatamos assim, a presença destes em estruturas visuais primárias.

A seguir, os resultados quantitativos e qualitativos serão mostrados seqüencialmente segundo os grupos dos receptores metabotrópicos estudados. Descreveremos inicialmente a expressão protéica e posteriormente mostraremos os resultados da imunorreatividade no núcleo geniculado lateral.

\subsubsection{Grupo I}

\subsubsection{1 mGluR1}

\section{EXPREssão Protéica}

No complexo geniculado lateral os resultados não apresentaram diferença estatisticamente significativa nos dias pós-lesão avaliados para mGluR1 (1ํ dia: $7,00 \% \pm 14,70, p=0,76 ; 7^{\circ}$ dia: $21,00 \% \pm 11,60, p=0,14 ; 15^{\circ}$ dia: $-11,00 \% \pm 7,70$, $p=0,41$ e de $1,60 \% \pm 5,80, p=0,85$ no $30^{\circ}$ dia) (Figuras $32 \mathrm{~A}$ e $B$ ). 


\section{Complexo Geniculado Lateral - mGluR1}

A)

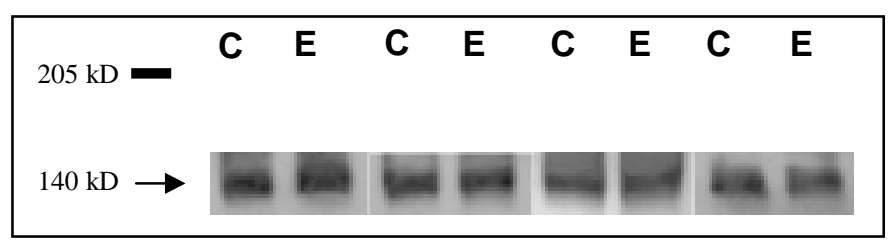

B)

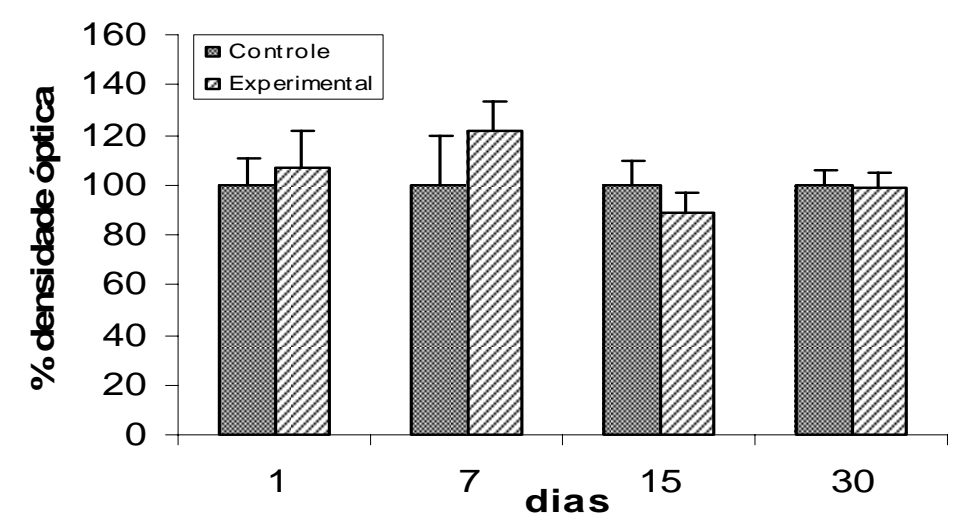

Figura 32. Efeito da enucleação ocular sobre a expressão de mGluR1 no complexo geniculado lateral (A e B) de ratos nos intervalos de 1, 7, 15 e 30 dias pós-lesão. Os dados estão representados por bandas (A) e em média da densidade óptica de bandas (B) para mGluR2/3. Os gráficos representam a porcentagem da densidade óptica no grupo experimental em relação ao controle, tomado como $100 \%$.

\section{IMUNORREATIVIDADE}

A imunorreatividade para mGluR1 no complexo geniculado lateral de ratos foi observada na neurópila tanto na região dorsal quanto na ventral, apresentando marcações bem difusas e difícil distinção do ruído de fundo (Figuras 33 e 34). Além disso, para mGluR1 observamos neurópila imunorreativa principalmente no núcleo geniculado ventral (Figura 34).

A expressão de mGluRs no complexo geniculado lateral talâmico não apresentou diferença na expressão no lado contralateral (experimental) após enucleação ocular. Esses resultados foram observados nos quatro tempos de sobrevida estudados, apesar de haver imunorreatividade para esses receptores no complexo geniculado (Figuras 33 e 34). 


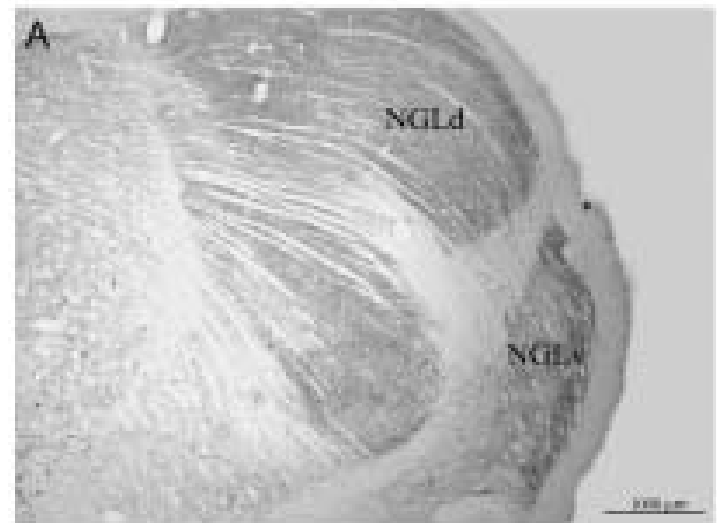

B)
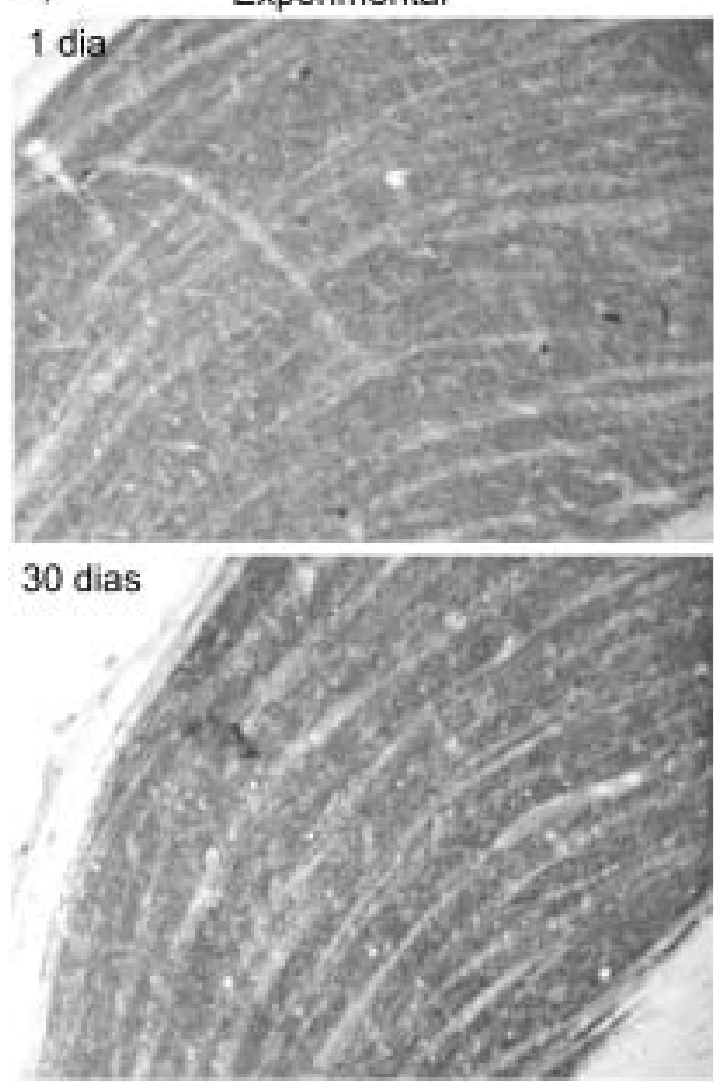

Controle
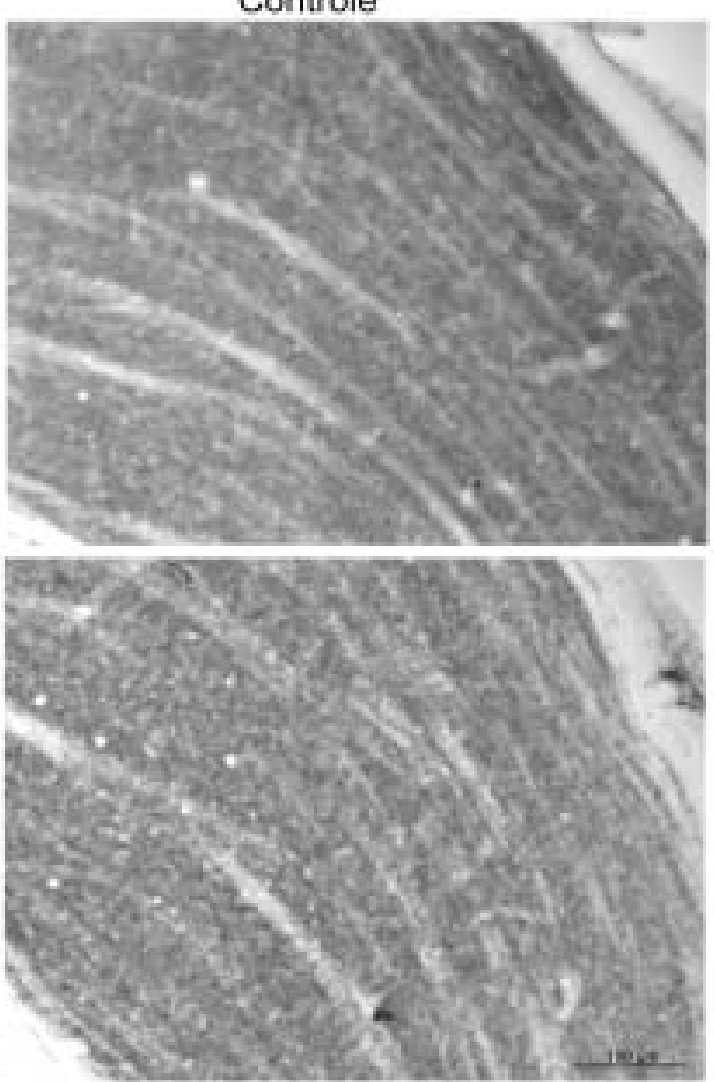

Figura 33. Imagem digital de corte coronal de encéfalo de ratos sem enucleação ocular, ilustrando o padrão de marcação para mGluR1 no NGL sem lesão (A) e após o $1^{\circ}$ e $30^{\circ}$ dias pós-lesão (B). $\mathrm{O}$ NGLd à esquerda de cada imagem representa o lado experimental, sem diferença da imunorreatividade para mGluR1. A figura em A mostra neurópila imunorreativa para mGluR1 no NGLd e NGLv. 

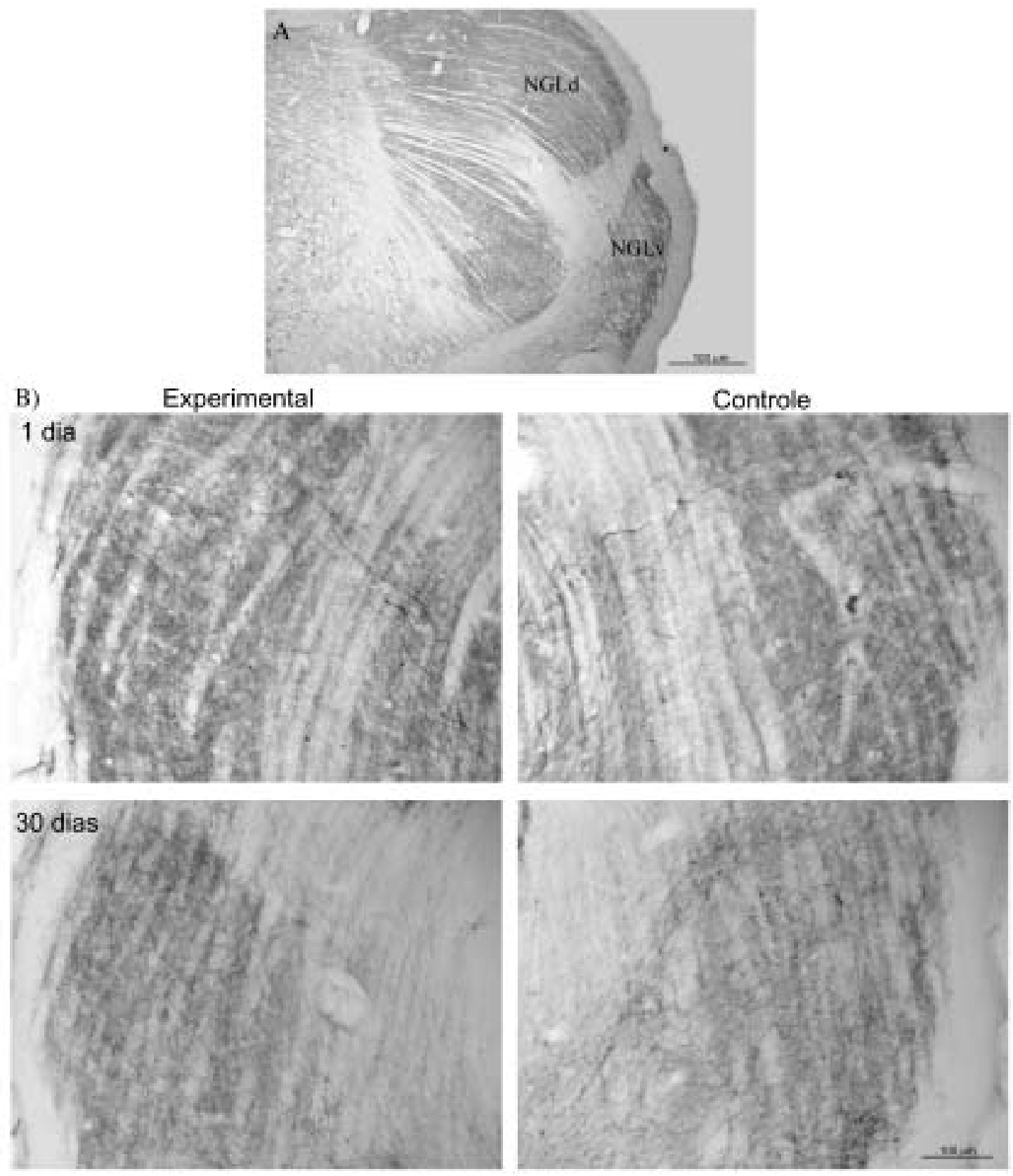

Figura 34. Imagem digital de corte coronal de encéfalo de ratos sem enucleação ocular, ilustrando o padrão de marcação para mGluR1 no NGL sem lesão (A) e após o $1^{\circ}$ e $30^{\circ}$ dias pós-lesão (B). $\mathrm{O}$ NGLv à esquerda de cada imagem representa o lado experimental, sem diferença da imunorreatividade para mGluR1. A figura em A mostra neurópila imunorreativa para mGluR1 no NGLd e NGLv. 


\subsubsection{2 mGluR5}

\section{EXPRESSÃo ProtéICA}

Já no complexo geniculado não observamos diferença significativa nos dias de sobrevidas estudados; os resultados foram: no 1ำ dia pós-lesão cerca de $9 \%$ $(8,70 \% \pm 5,00, p=0,28) ;$ no $7^{\circ}$ dia, $5 \%(5,10 \% \pm 5,80, p=0,39)$ e $30^{\circ}$ dia, $2 \%(1,80 \% \pm$ $11,10, p=0,50)$ a menos que o controle e no $15^{\circ}$ dia, cerca de $7 \%$ a mais $(6,80 \% \pm$ $11,10, p=0,50)$, ou seja, os resultados praticamente igualaram-se ao controle (Figuras 35A e B).

A)

\section{Complexo Geniculado Lateral - mGluR5}

B)
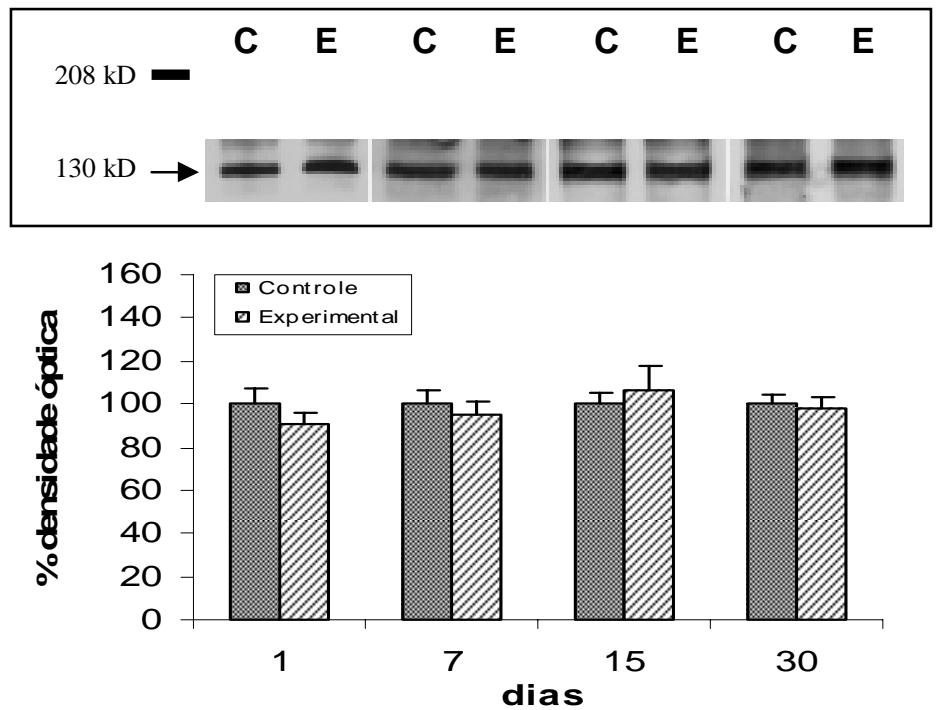

Figura 35. Efeito da enucleação ocular sobre a expressão de mGluR5 no complexo geniculado lateral (A e B) de ratos nos intervalos de 1, 7, 15 e 30 dias pós-lesão. Os dados estão representados por bandas (A) e em média da densidade óptica de bandas (B) para mGluR2/3. Os gráficos representam a porcentagem da densidade óptica no grupo experimental em relação ao controle, tomado como $100 \%$.

\section{IMUNORREATIVIDADE}

A imunorreatividade para mGluR5 no complexo geniculado lateral de ratos foi observada na neurópila tanto na região dorsal quanto na ventral, apresentando marcações bem difusas e difícil distinção do ruído de fundo. Não observamos diferença na imunorreatividade para esse receptor após enucleação em nenhum dos dias estudados (Figuras 36 e 37 ). 

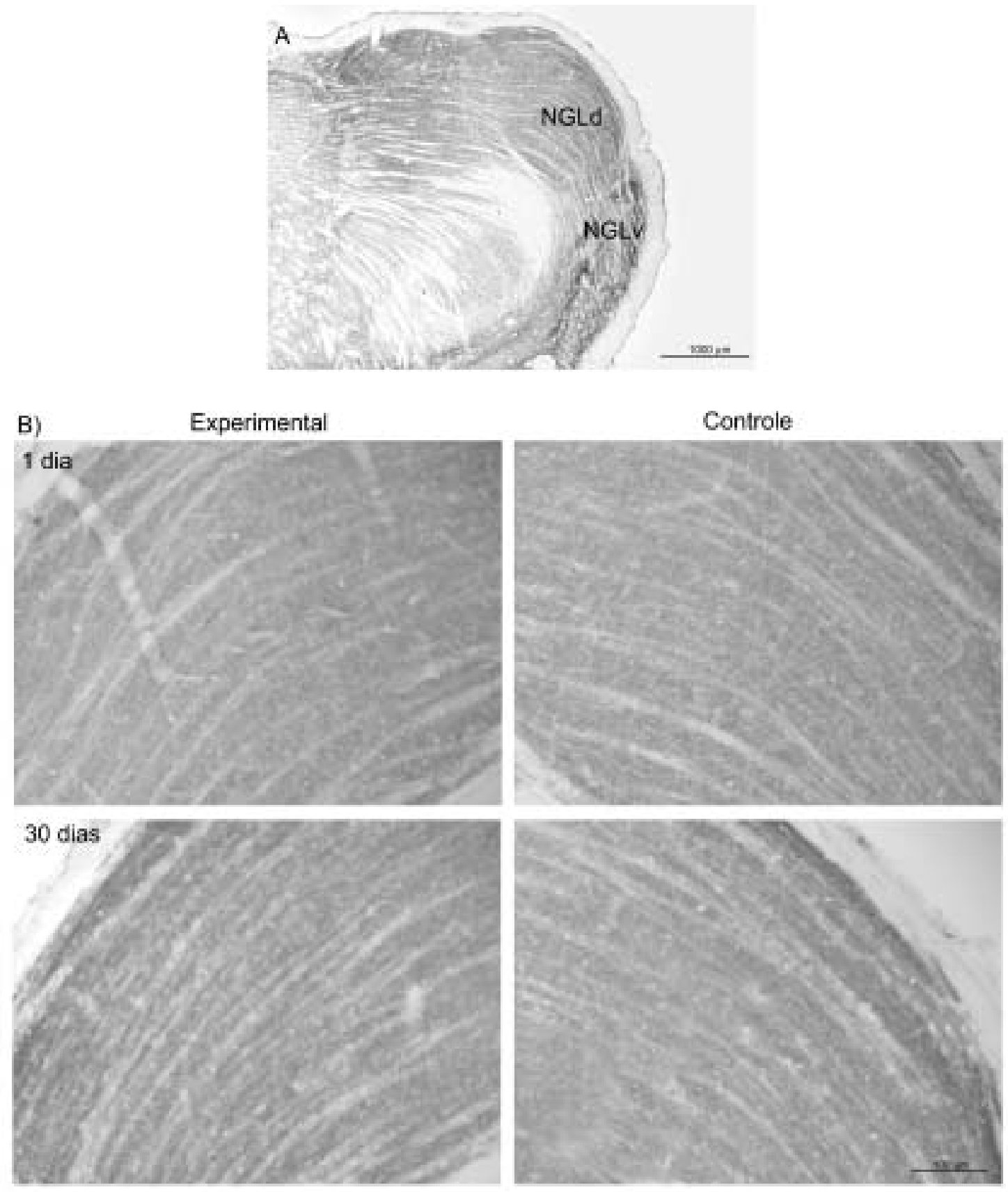

Figura 36. Imagem digital de corte coronal de encéfalo de ratos sem enucleação ocular, ilustrando o padrão de marcação para mGluR5 no NGL sem lesão (A) e após o $1^{\circ}$ e $30^{\circ}$ dias pós-lesão (B). O NGLd à esquerda de cada imagem representa o lado experimental, sem diferença da imunorreatividade para mGluR5. A figura em A mostra neurópila imunorreativa para mGluR5 no NGLd e NGLv. 

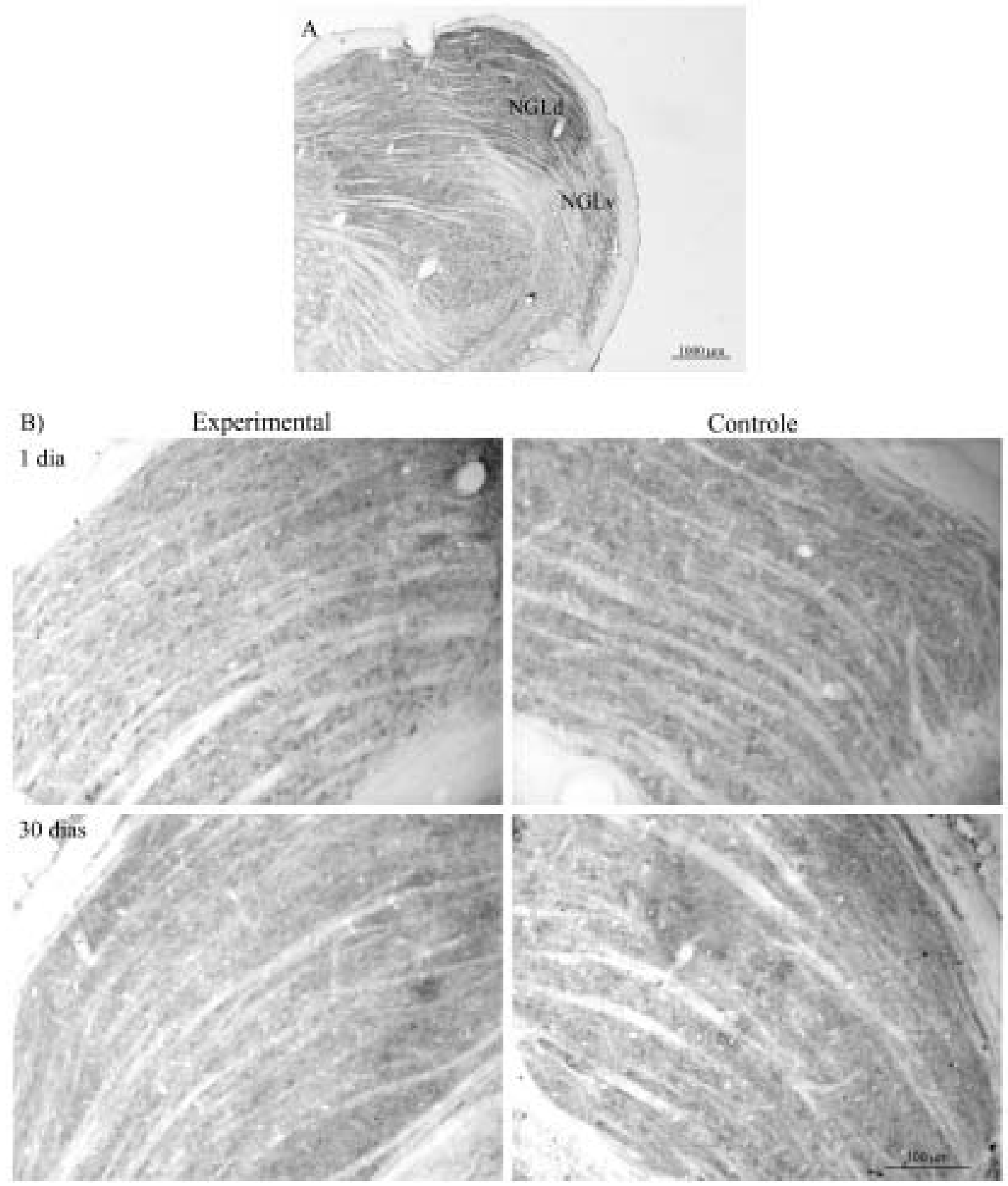

Figura 37. Imagem digital de corte coronal de encéfalo de ratos sem enucleação ocular, ilustrando o padrão de marcação para mGluR5 no NGL sem lesão (A) e após o $1^{\circ}$ e $30^{\circ}$ dias pós-lesão (B). O NGLv à esquerda de cada imagem representa o lado experimental, sem diferença da imunorreatividade para mGluR5. A figura em A mostra neurópila imunorreativa para mGluR5 no NGLd e NGLv. 


\subsubsection{Grupoll}

\subsubsection{1 mGluR2/3}

\section{EXPRESSÃo ProtéICA}

No complexo geniculado, os dados foram: no $1^{\text {OO }}$ dia pós-lesão foi de $6,50 \% \pm$ $10,10, p=0,73$ a menos que o controle e nos demais dias de sobrevida foram $1,50 \%$ $\pm 8,70, p=0,73$ no $7^{\circ}$ dia; $8,80 \% \pm 5,20, p=0,52$ no $15^{\circ}$ dia e $5,00 \% \pm 6,60, p=0,36$ no $30^{\circ}$ dia (Figuras 38A e B).

A)

Complexo Geniculado Lateral - mGluR2/3

B)

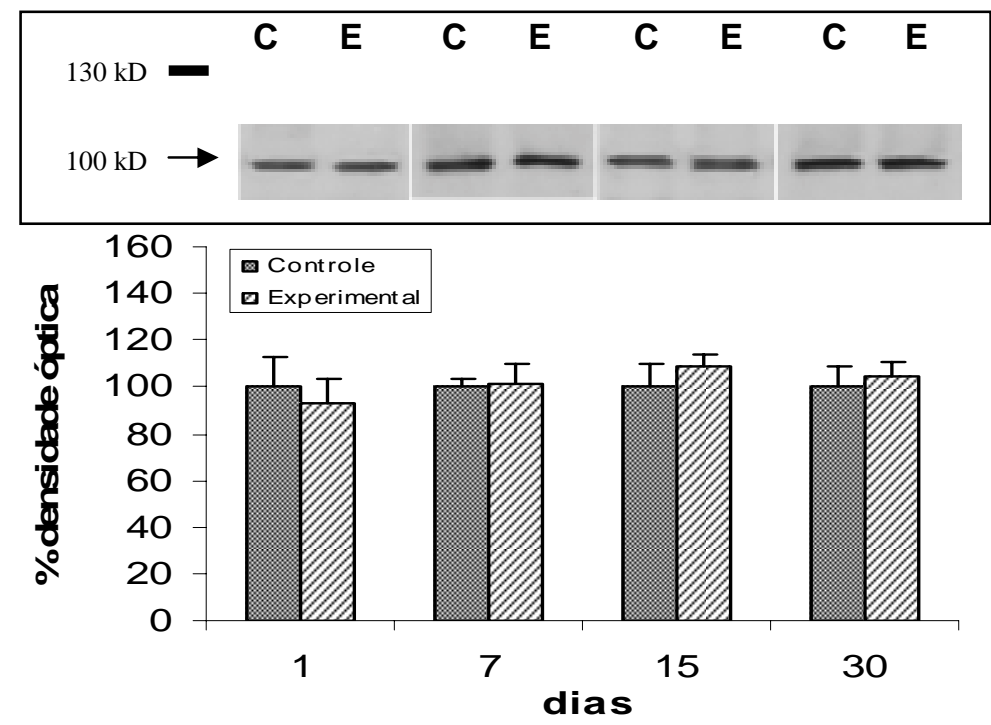

Figura 38. Efeito da enucleação ocular sobre a expressão de mGluR1 no complexo geniculado lateral (A e B) de ratos nos intervalos de 1, 7, 15 e 30 dias pós-lesão. Os dados estão representados por bandas (A) e em média da densidade óptica de bandas (B) para mGluR2/3. Os gráficos representam a porcentagem da densidade óptica no grupo experimental em relação ao controle, tomado como $100 \%$.

\section{IMUNORREATIVIDADE}

Para mGluR2/3 visualizamos neurópila imunorreativa no núcleo geniculado dorsal e ventral, como também pudemos observar pericários imunorreativos (Figuras 39 e 40). Não encontramos diferença em nenhum dos dias avaliados no núcleo geniculado lateral (Figuras 39 e 40). 

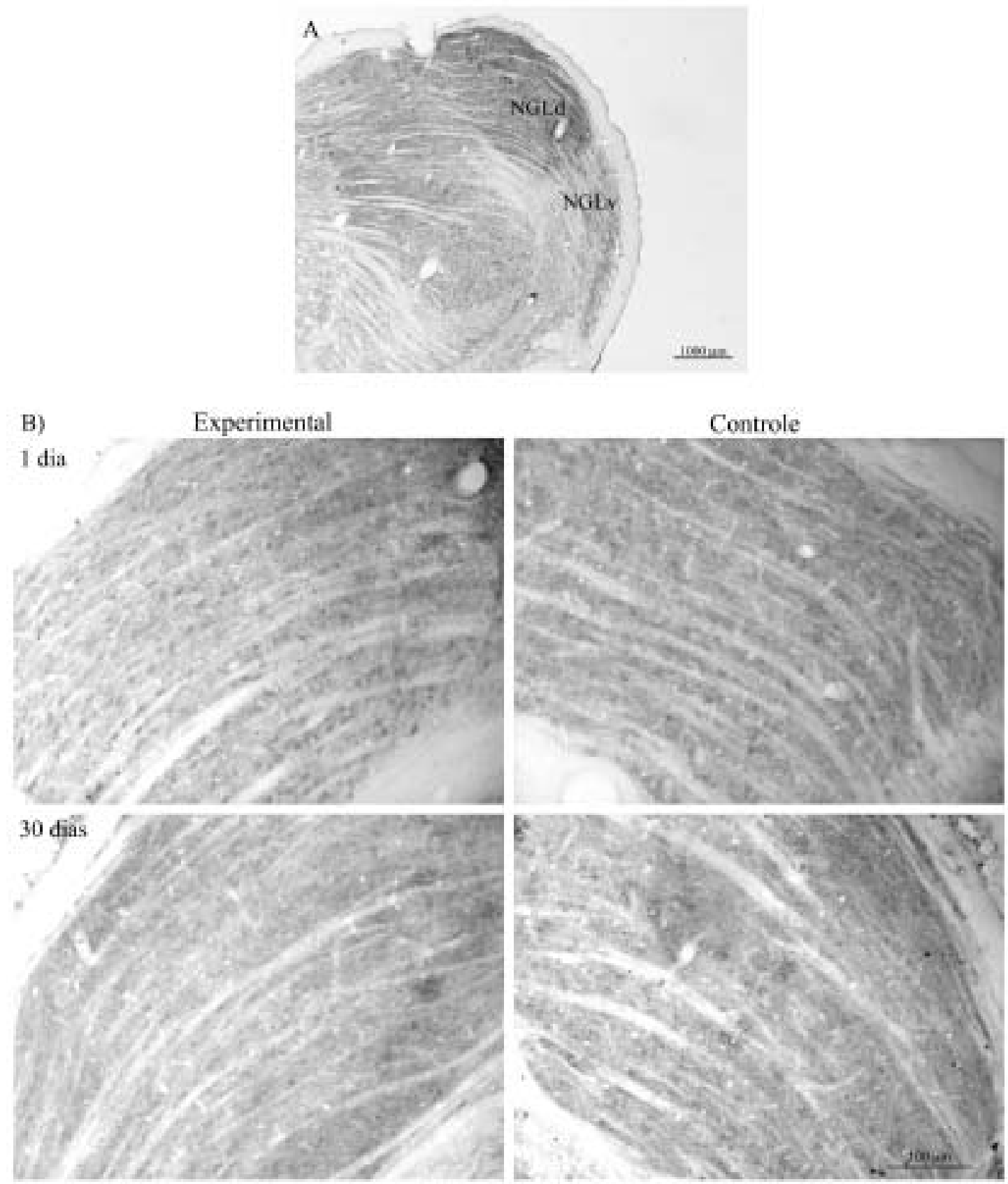

Figura 39. Imagem digital de corte coronal de encéfalo de ratos sem enucleação ocular, ilustrando o padrão de marcação para mGluR2/3 no NGL sem lesão (A) e após o $1^{\circ}$ e $30^{\circ}$ dias pós-lesão (B). O NGLd à esquerda de cada imagem representa o lado experimental, sem diferença da imunorreatividade para mGluR2/3. A figura em A mostra neurópila imunorreativa para mGluR2/3 no NGLd e NGLv. 


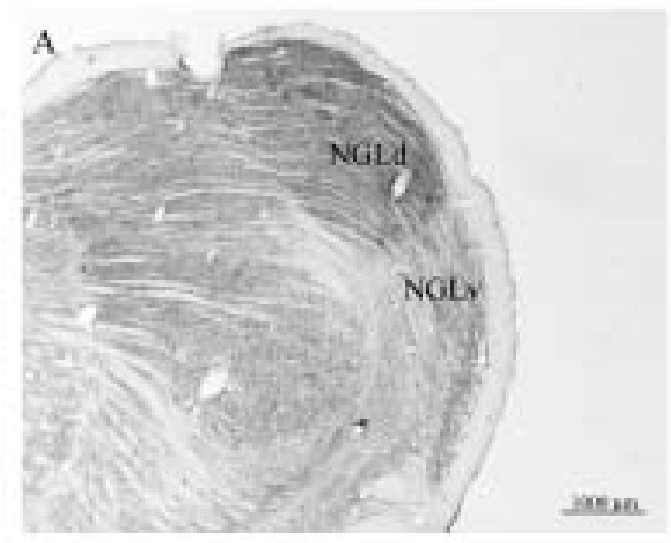

B)
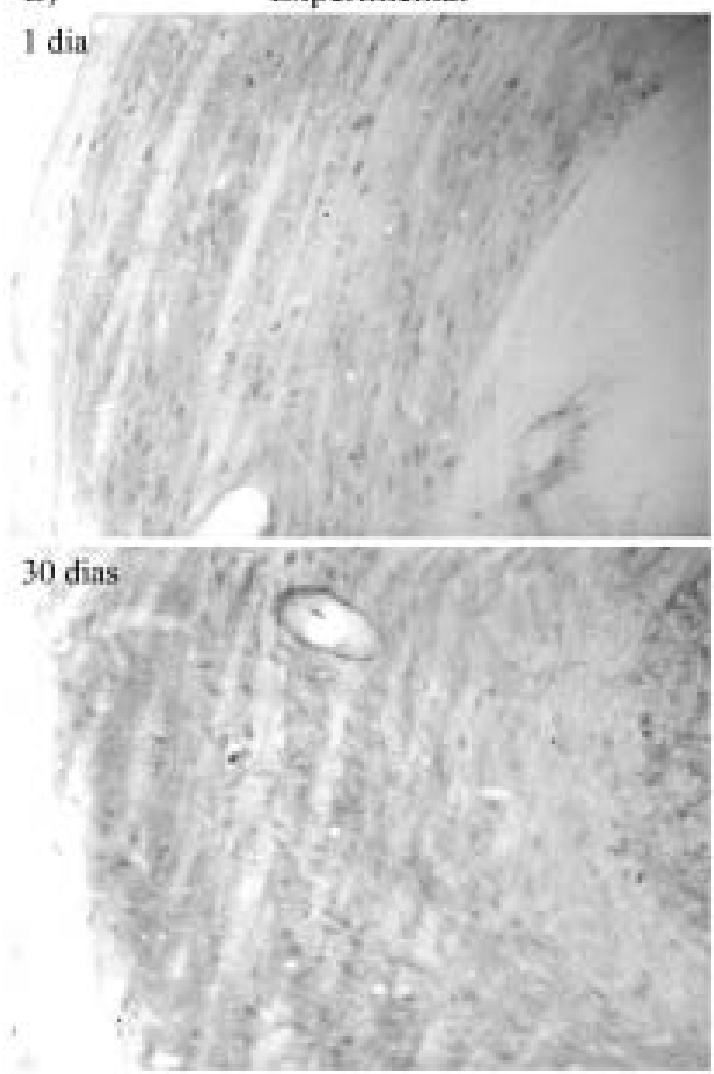

Controle
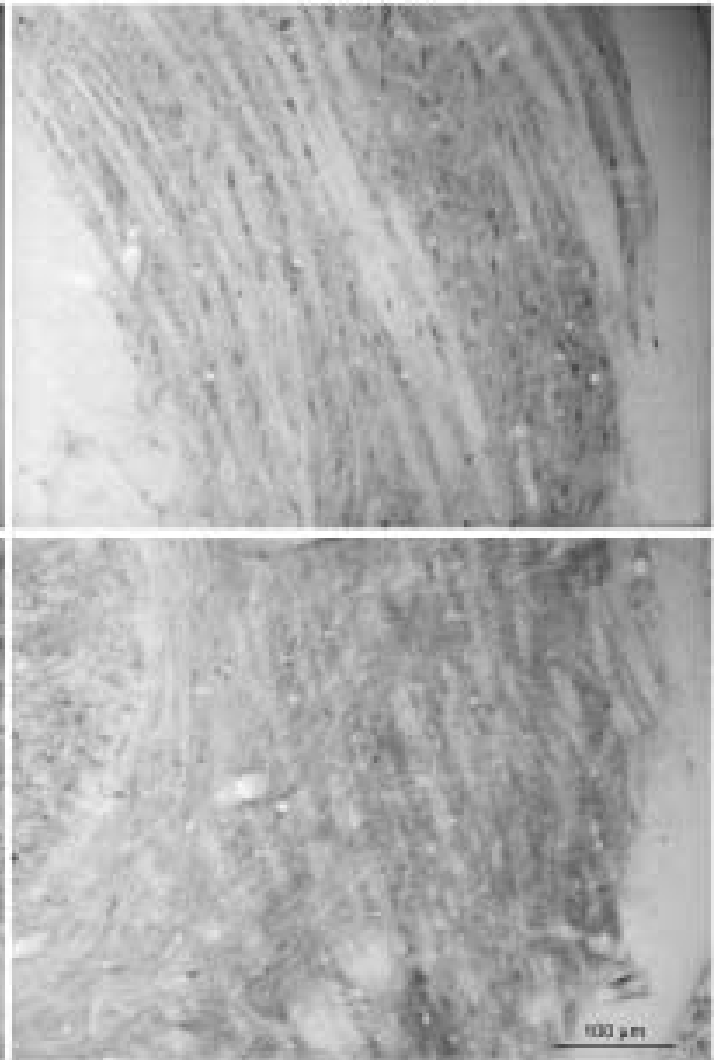

Figura 40. Imagem digital de corte coronal de encéfalo de ratos sem enucleação ocular, ilustrando o padrão de marcação para mGluR2/3 no NGL sem lesão (A) e após o $1^{\circ}$ e $30^{\circ}$ dias pós-lesão (B). O NGLv à esquerda de cada imagem representa o lado experimental, sem diferença da imunorreatividade para mGluR2/3. A figura em A mostra neurópila imunorreativa para mGluR2/3 no NGLd e NGLv. 


\subsubsection{Grupolll}

\subsubsection{1 mGluR7}

\section{EXPRESSÃo ProtéICA}

Também para o mGluR7, a expressão protéica no complexo geniculado não apresentou diferença significativa nos tempos de sobrevida estudados (10 dia póslesão: redução de $3,60 \% \pm 8,60, p=0,81$; um leve aumento no $7^{\circ}$ dia: $17,10 \% \pm 6,70$, $p=0,28$; no $15^{\circ}$ dia: redução de $8,60 \% \pm 4,00, p=0,37$ e no $30^{\circ}$ dia foi de $6,10 \% \pm$ $16,00, p=0,48$ ); Figuras $41 \mathrm{~A}$ e $\mathrm{B}$.

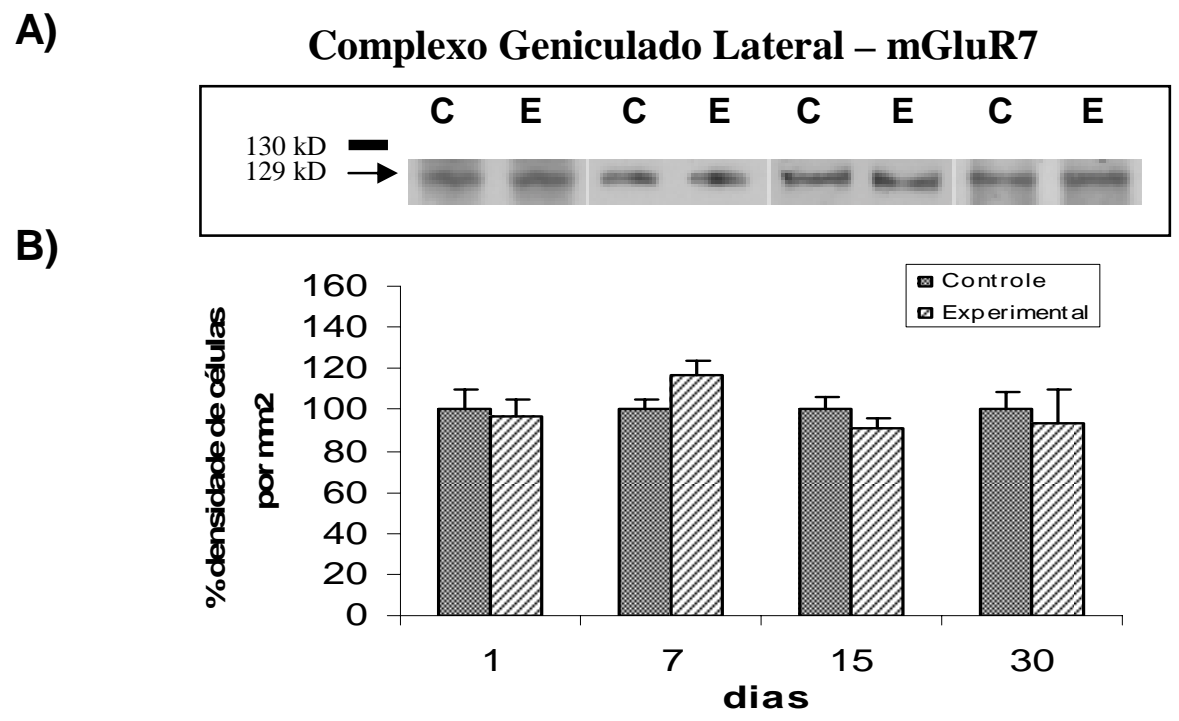

Figura 41. Efeito da enucleação ocular sobre a expressão de mGluR7 no complexo geniculado lateral (A e B) de ratos nos intervalos de 1, 7, 15 e 30 dias pós-lesão. Os dados estão representados por bandas (A) e em média da densidade óptica de bandas (B) para mGluR7. Os gráficos representam a porcentagem da densidade óptica no grupo experimental em relação ao controle, tomado como $100 \%$.

\section{IMUNORREATIVIDADE}

Entretanto, para mGluR7 visualizamos neurópila imunorreativa nos núcleos geniculados dorsal e ventral, como também pudemos observar pericários imunorreativos (Figuras 42 e 43). Também não encontramos diferença na imunorreatividade para essa proteína (Figuras 42 e 43). 

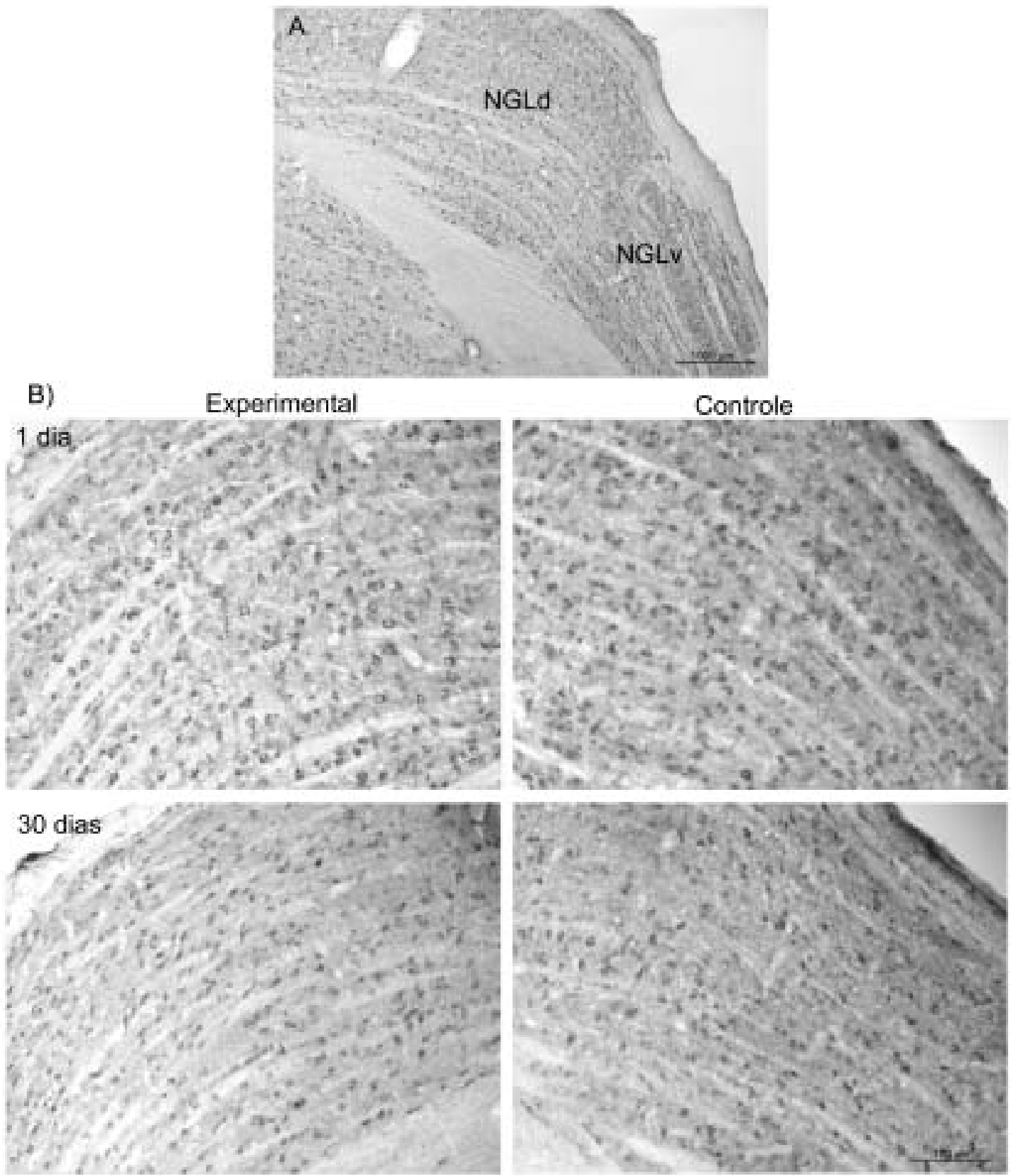

Figura 42. Imagem digital de corte coronal de encéfalo de ratos sem enucleação ocular, ilustrando o padrão de marcação para mGluR7 no NGL sem lesão (A) e após o $1^{\circ}$ e $30^{\circ}$ dias pós-lesão (B). $\mathrm{O}$ NGLd à esquerda de cada imagem representa o lado experimental, sem diferença da imunorreatividade em neurópila e em pericários para mGluR7. 

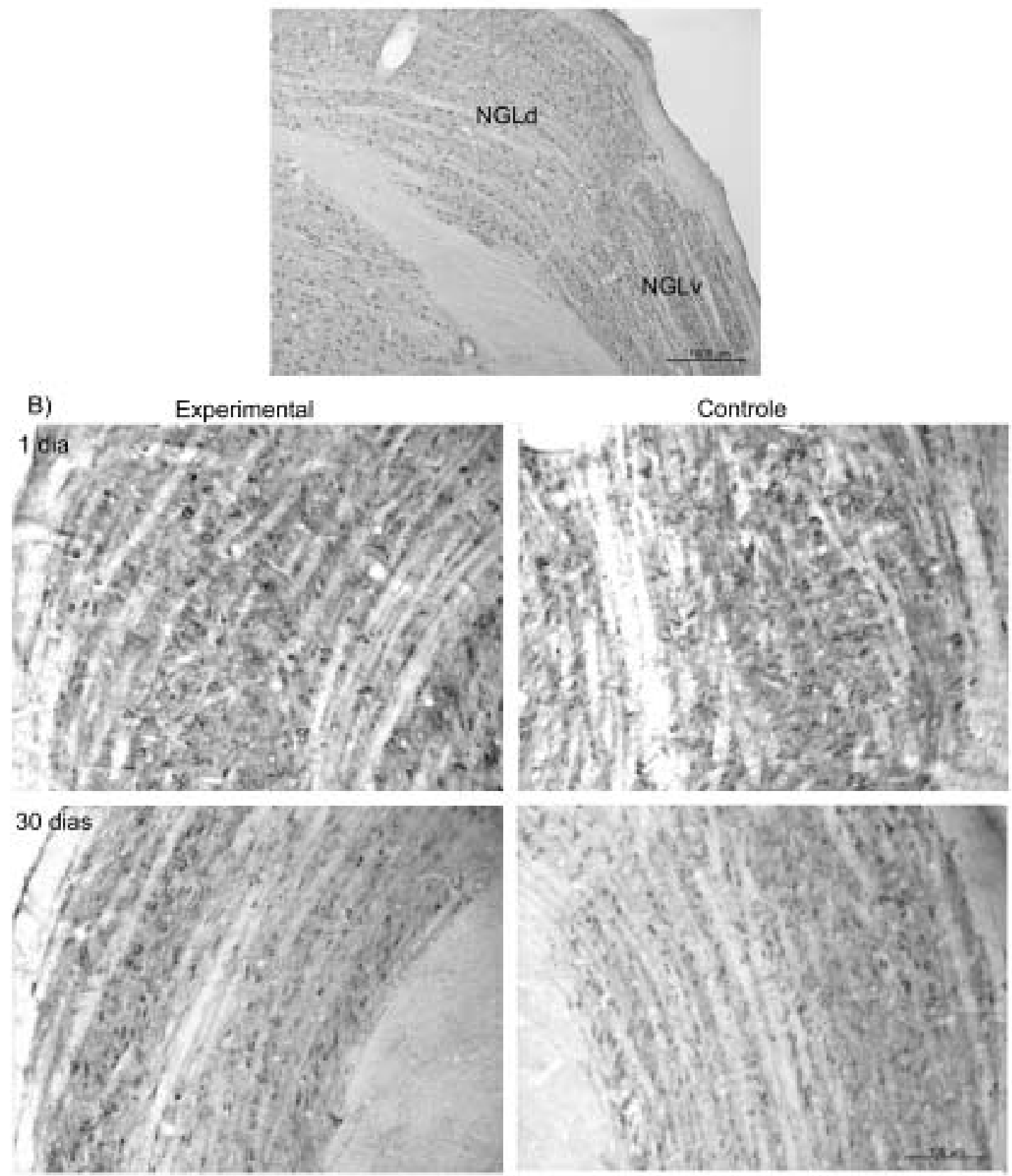

Figura 43. Imagem digital de corte coronal de encéfalo de ratos sem enucleação ocular, ilustrando o padrão de marcação para mGluR7 no NGL sem lesão (A) e após o $1^{\circ}$ e $30^{\circ}$ dias pós-lesão (B). O NGLv à esquerda de cada imagem representa o lado experimental, sem diferença da imunorreatividade em neurópila e em pericários para mGluR7. 


\subsection{RESUMO dOS RESULTADOS PARA O NÚCLEO GENICULADO LATERAL}

Tabela 4. Resultados resumidos das análises da expressão gênica, protéica e da imunorreatividade para mGluR1, mGluR2/3, mGluR5 e mGluR7 complexo geniculado lateral de ratos no $1^{\circ}, 7^{\circ}, 15^{\circ}$ e $30^{\circ}$ dias após a enucleação ocular.

\section{Complexo Geniculado}
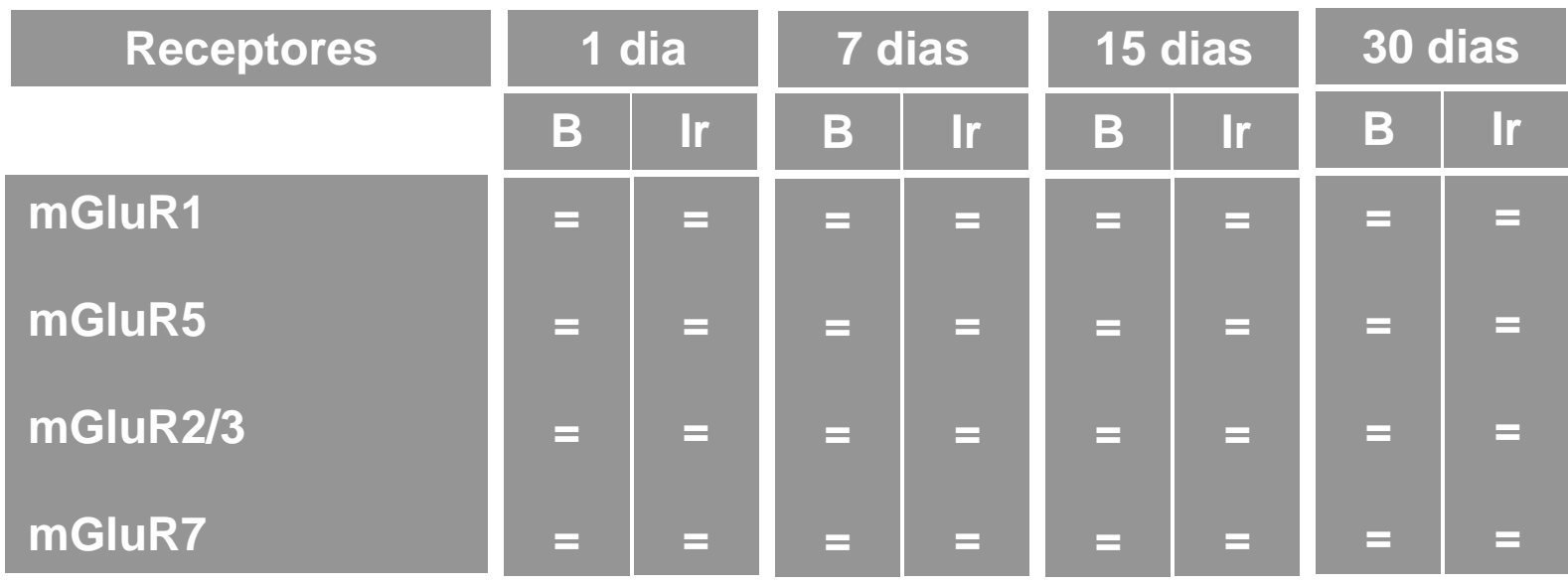

$\begin{array}{ll}= & = \\ = & = \\ = & = \\ = & =\end{array}$

\begin{tabular}{l|l}
$=$ & $=$ \\
$=$ & $=$ \\
$=$ & $=$ \\
$=$ & $=$
\end{tabular}

$R T=R T-P C R ; B=$ immunoblotting; Ir=imunorreatividade

$=$ não há diferença entre o geniculado lateral experimental e controle. 


\subsection{AVALIAÇÃO DA EXPRESSÃO PROTÉICA E DA DISTRIBUIÇÃO DOS mGluRs NO TECTO ÓPTICO DE PINTOS}

No $\mathrm{TeO}$ de pintos, a análise quantitativa dos resultados obtidos com ensaios de immunoblotting confirmou que os anticorpos utilizados neste estudo, contra mGluR1, mGluR5 e mGluR2/3 reconhecem bandas em torno de 140kD, 130kD e $100 \mathrm{kD}$, respectivamente, tanto para o lado controle quanto para o experimental. Referente ao controle interno do experimento, a análise densitométrica das bandas da $\beta$-actina não apresentou diferença estatística no TeO (Figura 44). Os dados mostram que houve uma modulação na expressão das proteínas correspondentes a mGluR1 (Figuras 45), mGluR2/3 (Figuras 49) e mGluR5 (Figuras 52) no TeO.

$\mathrm{Na}$ Figura 46 visualizamos as camadas do tecto óptico $(\mathrm{TeO})$. A nomenclatura de Cajal (1911) descreve que o TeO possui 15 camadas facilmente identificáveis; os terminais axônicos das células ganglionares da retina atingem as camadas 2, 3, 4, 5 e 7. Além disso, o $\mathrm{TeO}$ também é alvo de aferências provenientes de várias estruturas do telencéfalo, diencéfalo e mesencéfalo (Luksch e Poll, 2002) (Figura 46). Nessas camadas e nas profundas, em nossos dados, pudemos observar imunorreatividade para mGluR1, mGluR5 e mGluR2/3. Constatamos assim, a presença destes receptores em estruturas visuais primárias de pintos. Além disso, observamos que os terminais provenientes do núcleo do istmo parvocelular (Ipc) e núcleo istmo magnocelular (Imc) contêm poucos receptores do grupo II. (Figura 55)

A seguir, os resultados quantitativos e qualitativos serão mostrados seqüencialmente segundo os grupos dos receptores metabotrópicos estudados. Descreveremos inicialmente a expressão protéica e posteriormente mostraremos a imunorreatividade para os mGluRs no TeO.

\subsubsection{Grupol}

\subsubsection{1 mGluR1}

\section{EXPRESSÃo ProtéICA}

Não houve diferença na expressão de $\beta$-actina entre 0 controle e 0 experimental em nenhum dos dias avaliados (Figura 44), indicando que a diferença na expressão protéica dos mGluRs encontrada foi devida a lesão. 
Para mGluR1, a análise densitométrica no TeO apresentou aumento no $1^{\text {ㅇ }}$ $(18,60 \% \pm 4,90, p<0,05)$, 15 $(20,30 \% \pm 6,80, p<0,05)$ e $30^{\circ}(18,30 \% \pm 2,80, p<0,05)$ dias pós-lesão e esses níveis não foram significativos no $7^{\circ}$ dia $(16,00 \% \pm 7,10$, $p=0,19)$; Figuras 45A e B.

A)

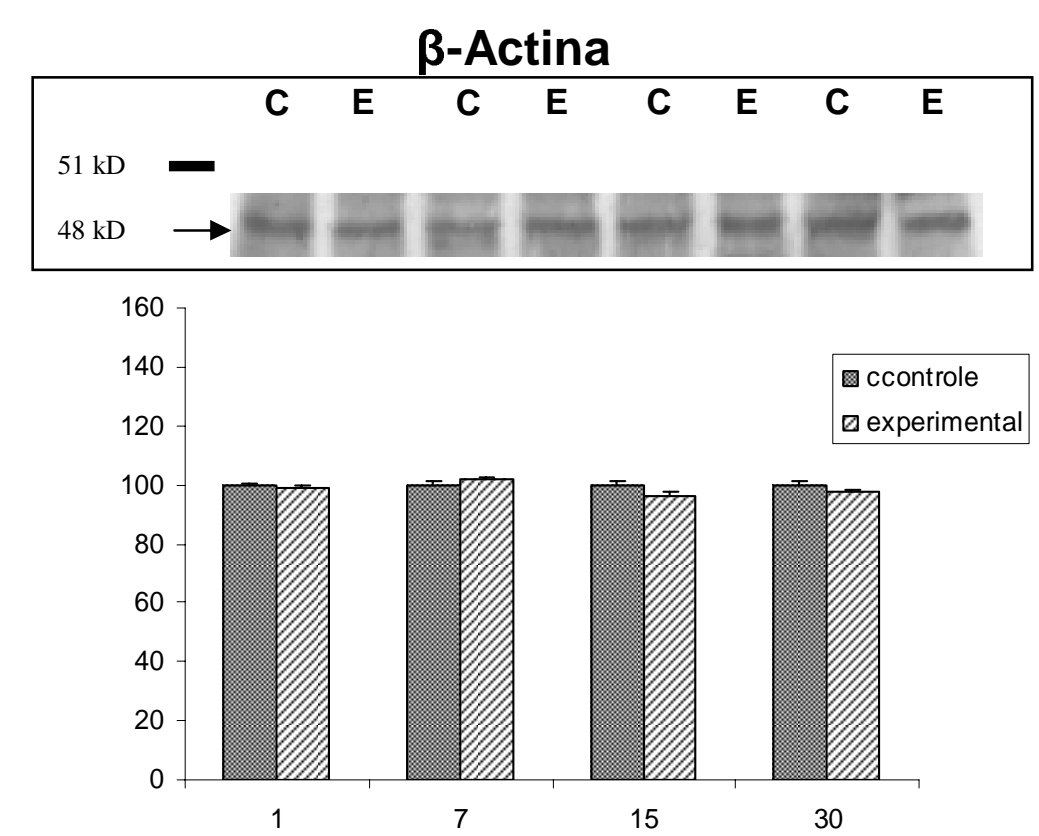

Figura 44. Análise densitométrica das bandas marcadas com anti $\beta$-actina no tecto óptico de pintos. Não houve diferença significativa entre o controle e experimental.

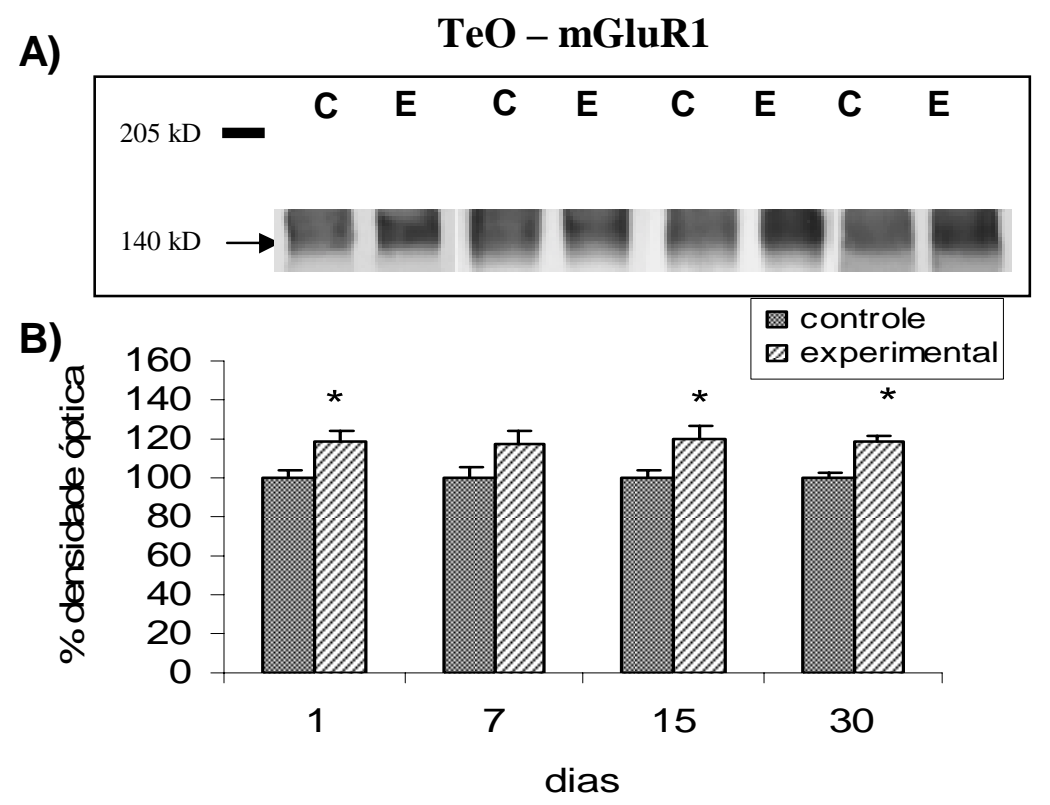

Figura 45. Efeito da enucleação ocular sobre a expressão de mGluR1 (A e B) no TeO de pintos nos intervalos de 1, 7, 15 e 30 dias pós-lesão. Os dados estão representados por bandas (A) e em média da densidade óptica de bandas imunorreativas (B). Os gráficos representam a porcentagem da densidade óptica no grupo experimental em relação ao controle, tomado como $100 \%$. $* \mathrm{p}<0,05$. 


\section{IMUNORREATIVIDADE}

A análise da expressão de mGluR1 revelada por imunoperoxidase em cortes coronais de encéfalos de pintos mostrou que há neurópila marcada nas camadas 2 , 5, 6, 8 e pericários na camada 13 (Figura 47). A expressão de mGluR1 após enucleação ocular foi alterada a partir do $1^{\circ}$ dia pós-lesão no lado contralateral (experimental) do TeO. Entretanto, esses aumentos foram observados principalmente em tempos de sobrevidas maiores (Figuras 47 e 48). Em relação aos pericários imunorreativos para esse subtipo não houve diferença após a enucleação ocular.

\section{$\mathrm{TeO}$}

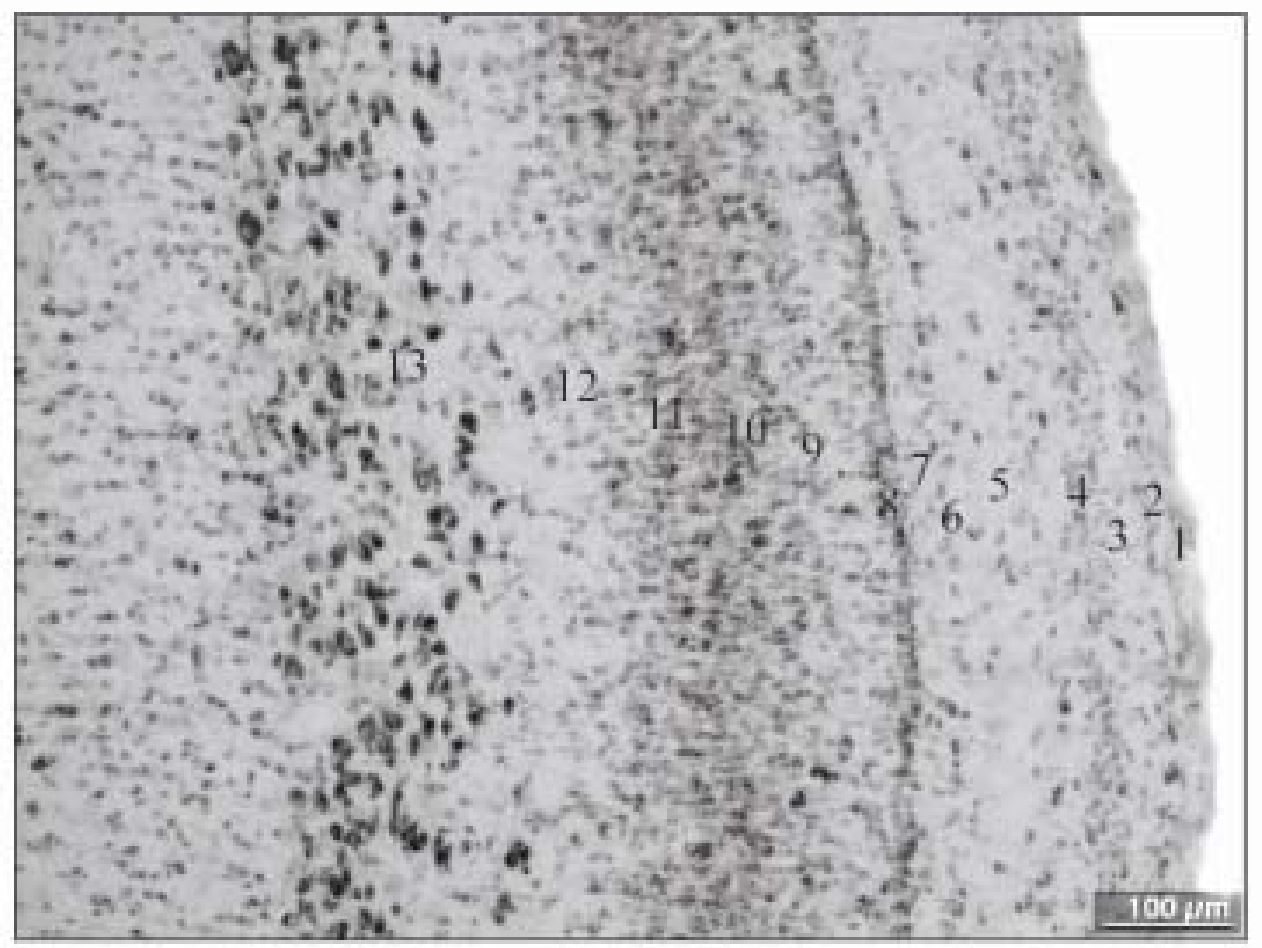

Figura 46. Imagem digital de corte coronal de encéfalo de pinto corado pelo método de Giemsa, mostrando as 13 camadas mais superficiais do $\mathrm{TeO}$. 


\section{mGluR1}
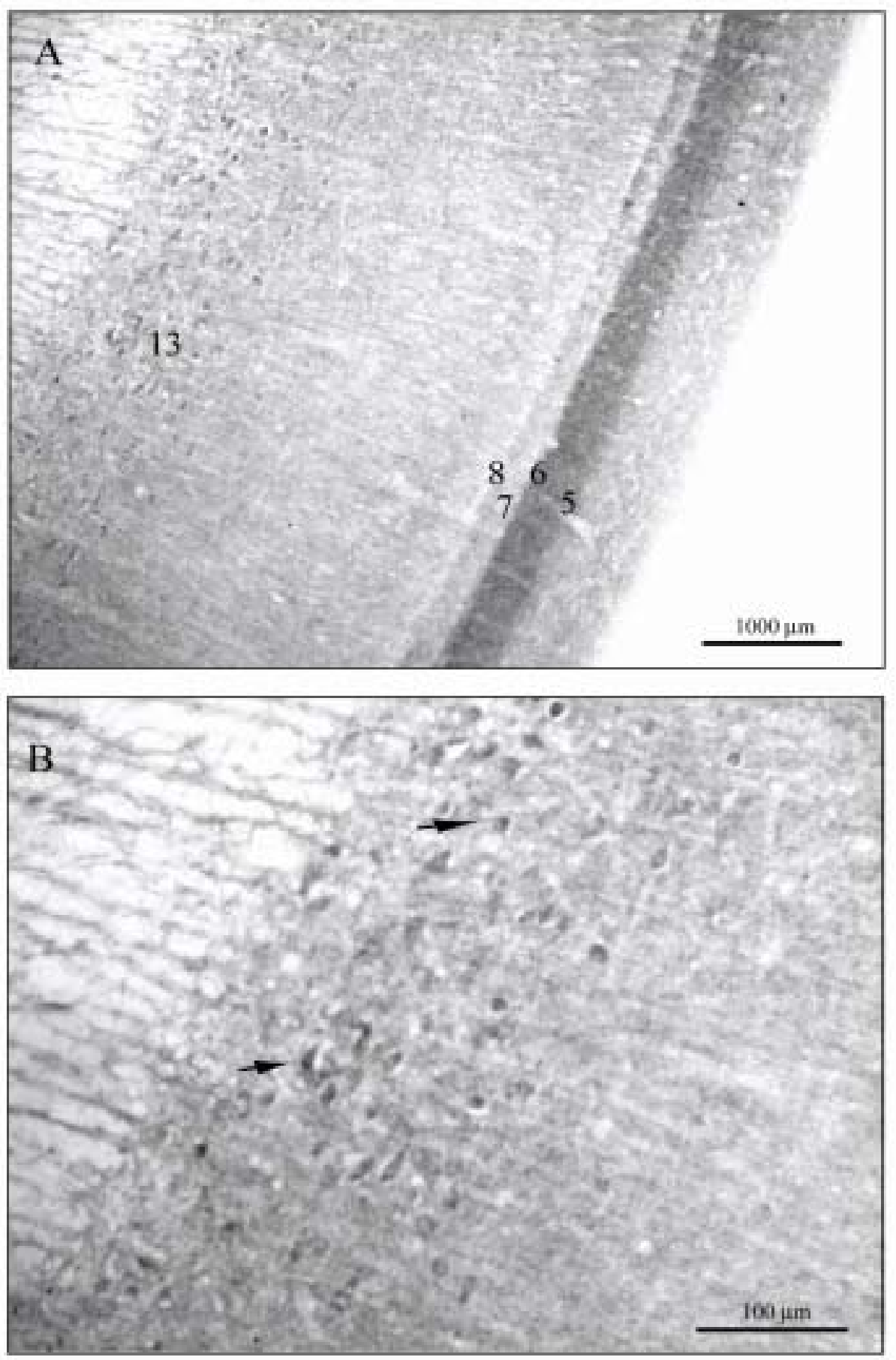

Figura 47. Imagens digitais de cortes coronais de encéfalo de pintos sem enucleação ocular, ilustrando o padrão de marcação para mGluR1 no tecto óptico (A). As setas em B indicam pericários marcados na camada 13 do TeO. Os números em A indicam as camadas. 


\section{mGluR1}
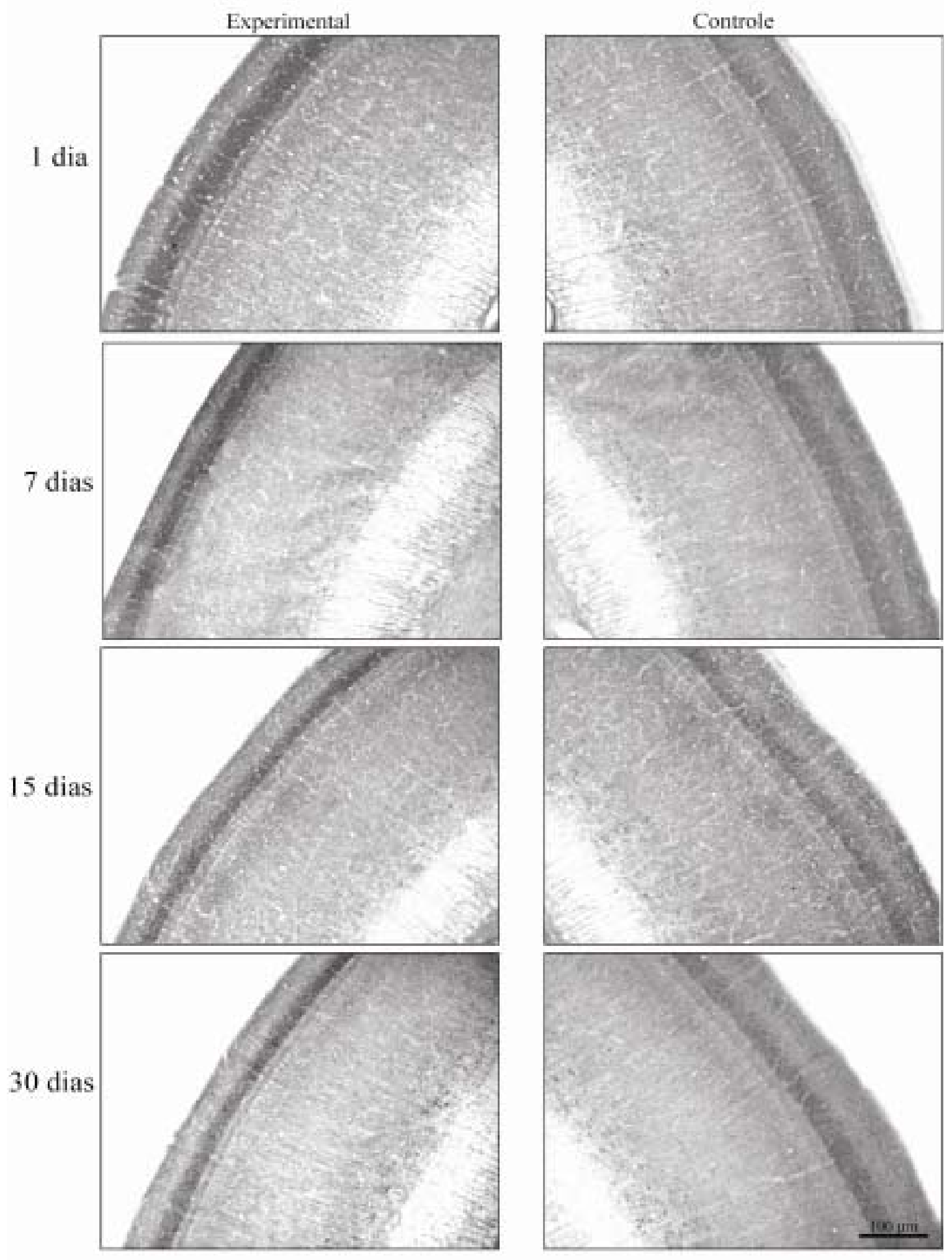

Figura 48. Imagens digitais de cortes coronais de encéfalo de pintos, ilustrando o padrão de marcação para mGluR1 no TeO em diferentes tempos de sobrevida de lesões: $1,7,15$ e 30 dias. $\mathrm{O} \mathrm{TeO}$ à esquerda de cada imagem representa o lado experimental com aumento da imunorreatividade para mGluR1. 


\subsubsection{2 mGluR5}

\section{EXPRESSÃo ProtéICA}

Nossos resultados de immunoblotting para o outro subtipo do grupo I, o mGluR5, apresentaram um aumento significativo nos níveis protéicos de $13 \%$ $(12,50 \% \pm 6,10, p<0,05)$ no $1^{\circ}$ dia pós-lesão, de $19 \%(19,00 \% \pm 7,00, p<0,05)$ no $7^{\circ}$ dia, de $21 \%(20,60 \% \pm 5,70, p<0,05)$ no $15^{\circ}$ dia e no $30^{\circ}$ dia de $19 \%(18,70 \% \pm 8,60$, $p<0,05)$, Figuras $49 \mathrm{~A}$ e $B$.

A)

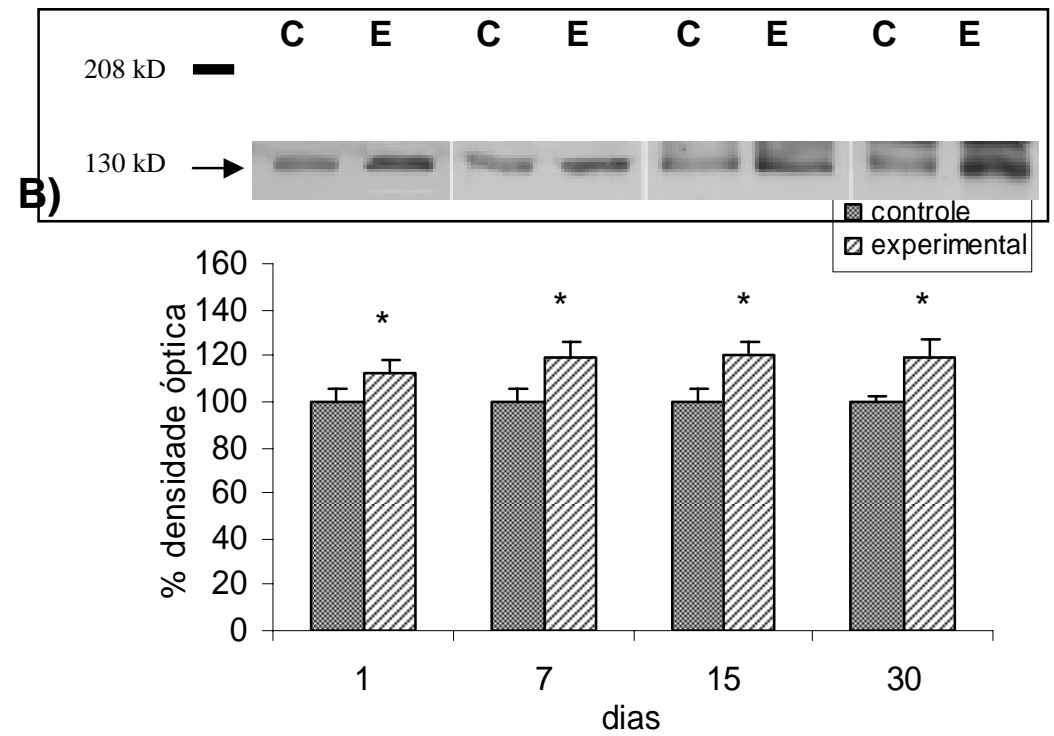

Figura 49. Efeito da enucleação ocular sobre a expressão de mGluR5 (A e B) no TeO de pintos nos intervalos de 1, 7, 15 e 30 dias pós-lesão. Os dados estão representados por bandas (A) e em média da densidade óptica de bandas imunorreativas (B) para esse mGluR. Os gráficos representam a porcentagem da densidade óptica no grupo experimental em relação ao controle, tomado como $100 \%$. * $\mathrm{p}<0,05$.

\section{IMUNORREATIVIDADE}

Já para mGluR5, a marcação ficou restrita à neurópila das camadas 2, 3, 5, 6 e 8 (Figura 50), mas intensa apenas nas camadas 2-3. Houve uma maior imunorreatividade nas camadas 2-3 após a lesão (Figura 51). Para mGluR5, o aumento foi observado desde $01^{\circ}$ dia pós enucleação ocular. Entretanto, esses aumentos foram observados principalmente em tempos de sobrevidas maiores (Figura 51). 


\section{mGluR5}

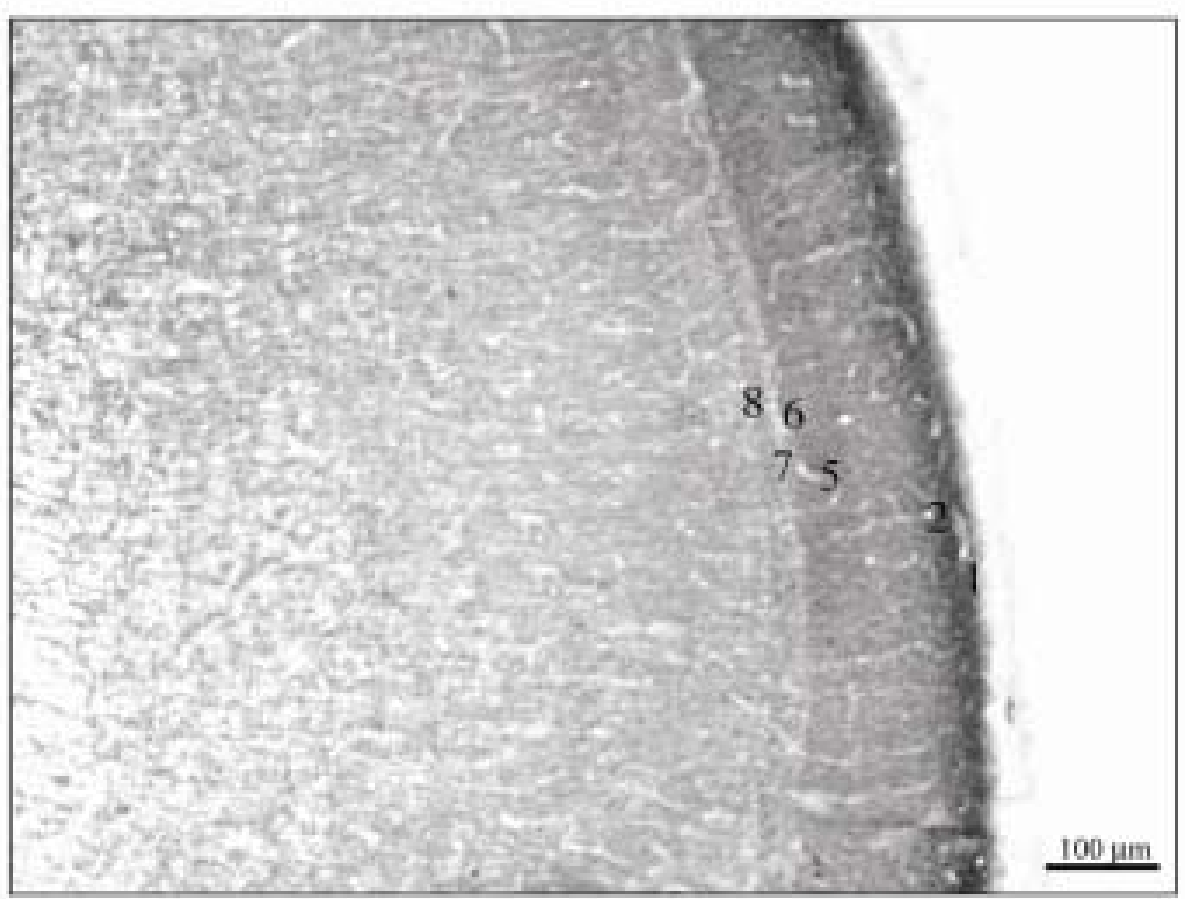

Figura 50. Imagens digitais de cortes coronais de encéfalos de pintos sem enucleação ocular, ilustrando o padrão de marcação para mGluR5 no tecto óptico. Os números em A indicam as camadas. 


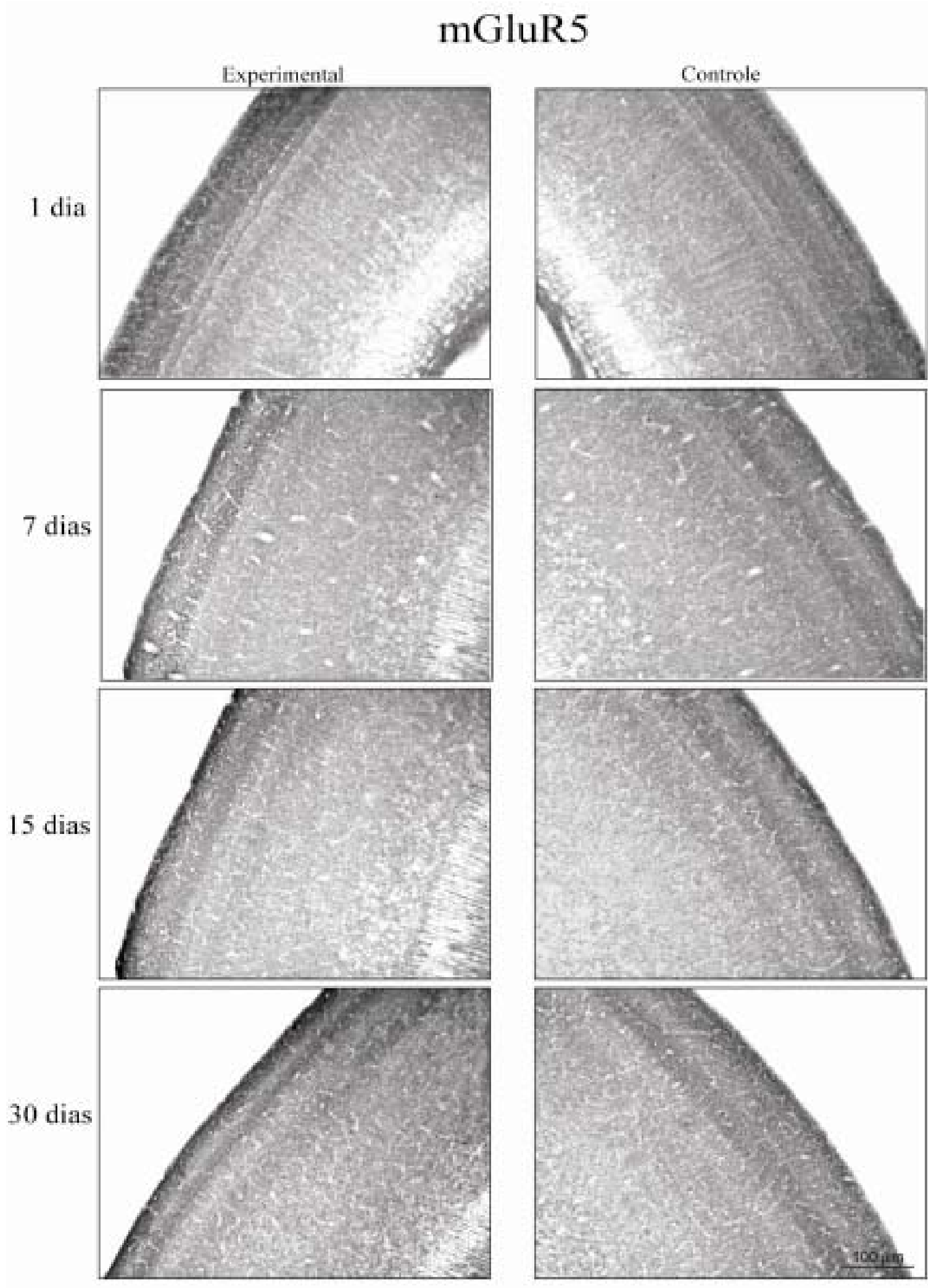

Figura 51. Imagens digitais de cortes coronais de encéfalo de pintos, ilustrando o padrão de marcação para mGluR5 no TeO em diferentes tempos de sobrevida de lesões:1, 7, 15 e 30 dias. $\mathrm{O} \mathrm{TeO}$ à esquerda de cada imagem representa o lado experimental com aumento da imunorreatividade para mGluR5. 


\subsubsection{Grupoll}

\subsubsection{1 mGluR2/3}

\section{ExPREssão ProtéICA}

Os resultados de immunoblotting mostraram que para o grupo II, mGluR2/3, encontramos níveis protéicos semelhantes ao controle nos $1^{\circ}=(9,90 \% \pm 10,00$, $\mathrm{p}=0,33)$ e $7^{\circ}(11,00 \% \pm 7,80, \mathrm{p}=0,12)$ dias pós-lesão e uma diminuição significativa nos $15^{\circ}(13,60 \% \pm 7,00, p<0,05)$ e $30^{\circ}$ dias $(17,60 \% \pm 4,40, p<0,05)$; Figuras $52 \mathrm{~A}$ e $\mathrm{B}$, dados estes que diferem daqueles encontrados no CS de ratos.

A)

TeO - mGluR2/3

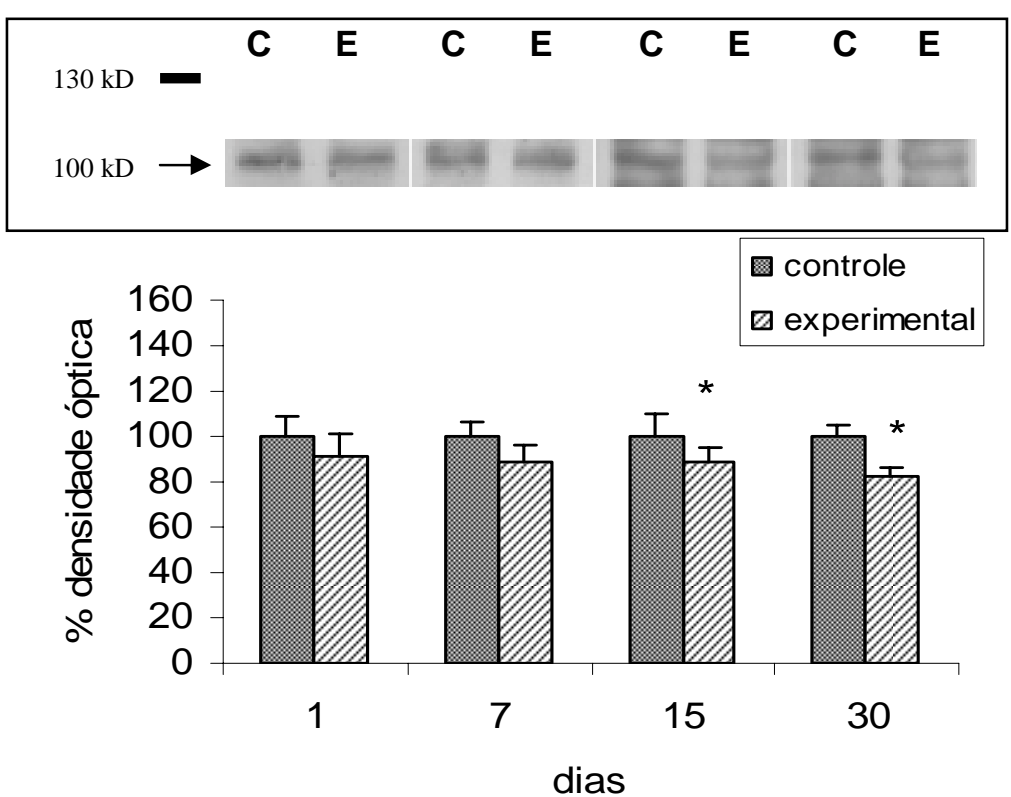

Figura 52. Efeito da enucleação ocular sobre a expressão de mGluR2/3 (A e B) no TeO de pintos nos intervalos de 15 e 30 dias pós-lesão. Os dados estão representados por bandas (A) e em média da densidade óptica de bandas imunorreativas (B) para esse mGluR. Os gráficos representam a porcentagem da densidade óptica no grupo experimental em relação ao controle, tomado como $100 \%$. $\mathrm{p}<0,05$.

\section{IMUNORREATIVIDADE}

Para mGluR2/3, o padrão de marcação é visualizado na neurópila das camadas 4, 5, 6 e 8 do TeO. Para esses receptores, pudemos observar também aglomerados de neurópila nas camadas 5-6 como ilustrado na Figura 53. Após a lesão, houve uma diminuição na expressão em neurópila; a partir do $7^{0}$ dia, 
pudemos observar também que houve alteração do seu padrão de marcação, que se apresentou contínuo e não mais em forma de grumos (Figura 54).

Para o mGluR7 não houve imunorreatividade com o anticorpo utilizado.

Em relação aos resultados com o biocitina, ao injetarmos o traçador neuronal nos núcleos Ipc e Imc em pintos, observamos que o perfil dos terminais provenientes desse núcleo contém poucos receptores do tipo mGluR2/3. Não observamos a presença desse subtipo nos terminais em forma de escova, embora raros pontos de co-localização estejam presentes (Figura 55). 


\section{mGluR2/3}
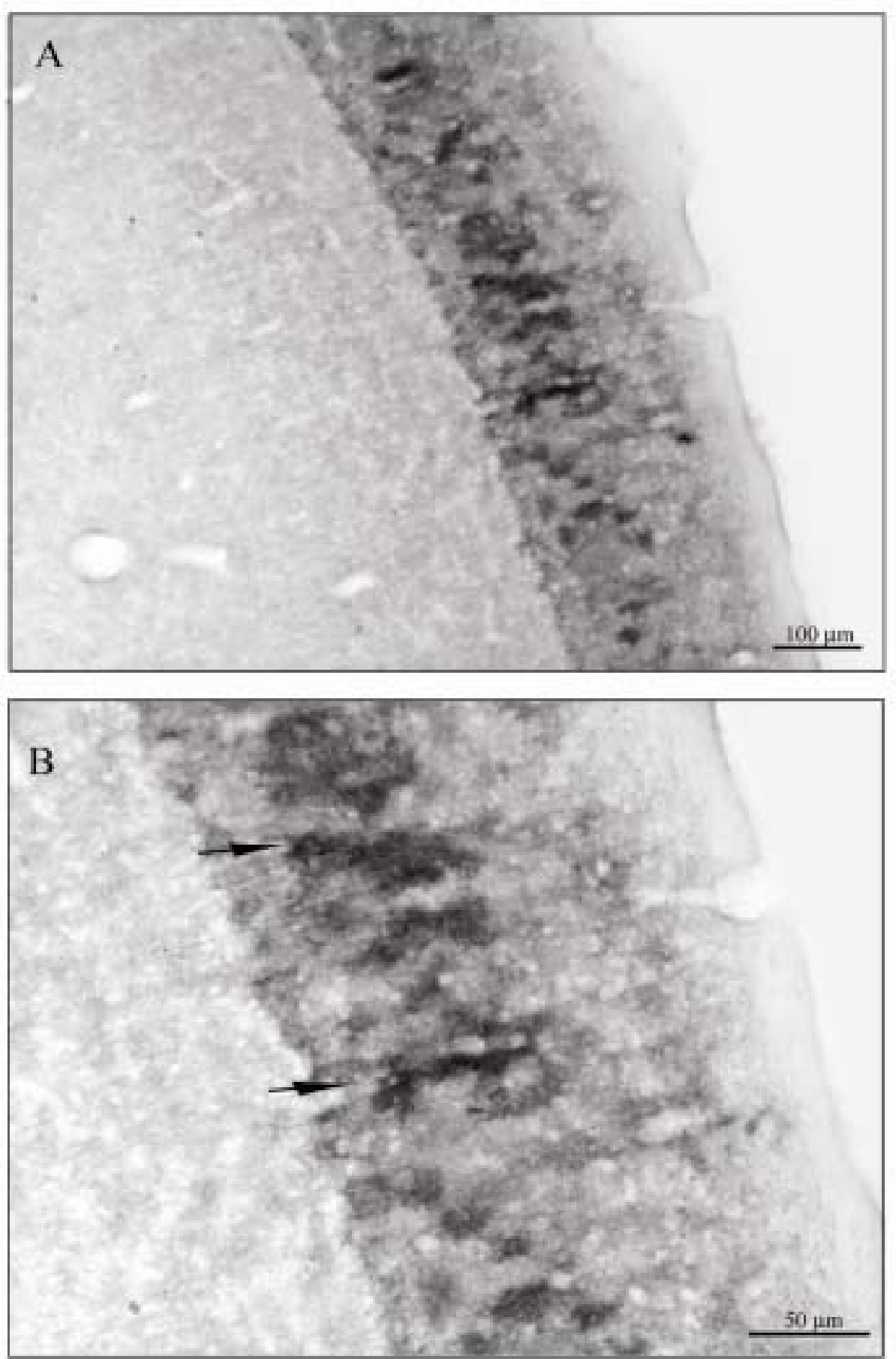

Figura 53. Imagens digitais de cortes coronais de encéfalo de pintos sem enucleação ocular, ilustrando o padrão de marcação para mGluR2/3 no tecto óptico. As setas nas figuras B indicam os aglomerados de neurópila nas camadas 5 e 6 do TeO. 


\section{mGluR2/3}
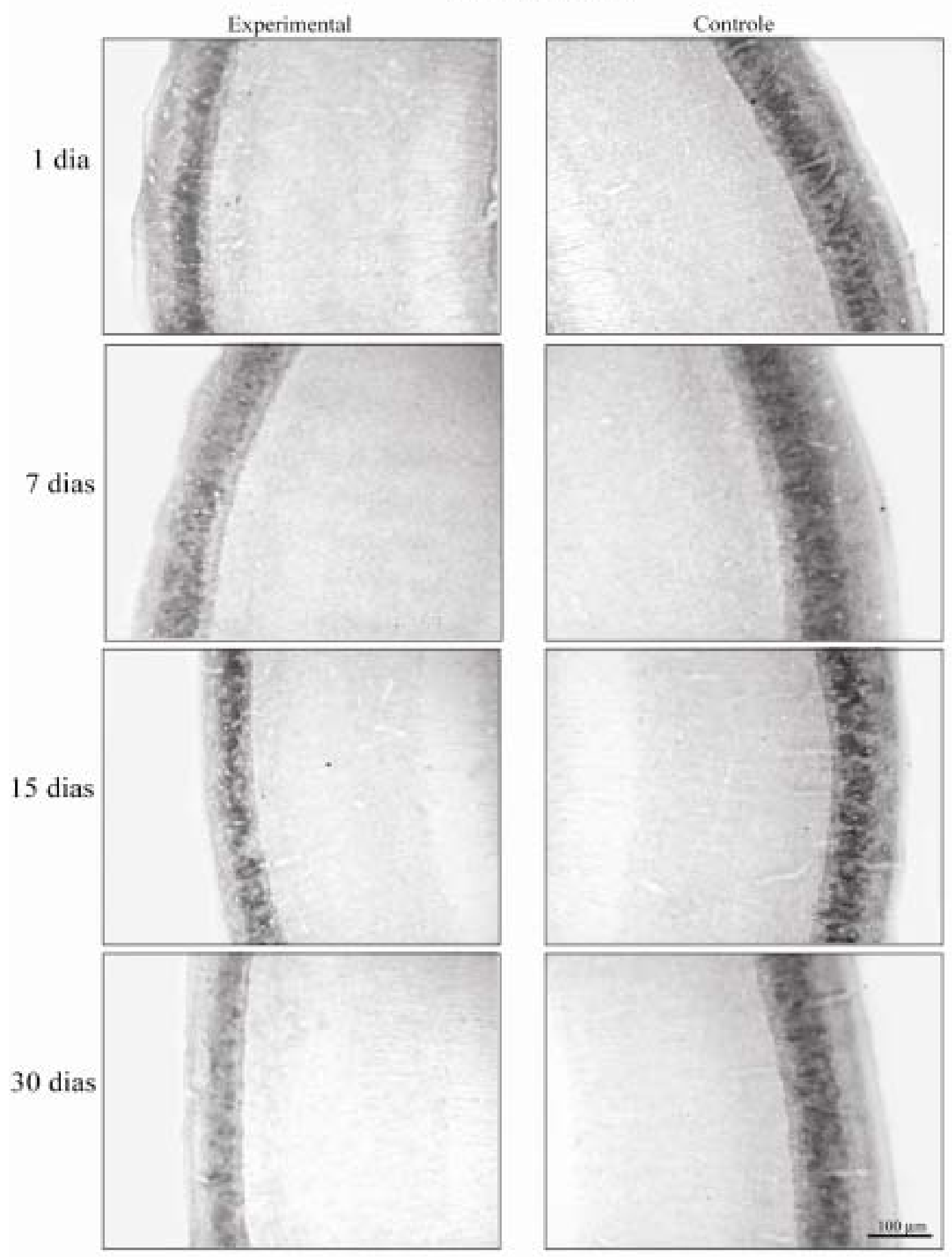

Figura 54. Imagens digitais de cortes coronais de encéfalo de pintos, ilustrando o padrão de marcação para o mGluR2/3 no TeO em diferentes tempos de sobrevida de lesões: 1, 7, 15 e 30 dias. $\mathrm{O}$ TeO à esquerda de cada imagem representa o lado experimental com diminuição da imunorreatividade para mGluR2/3. 


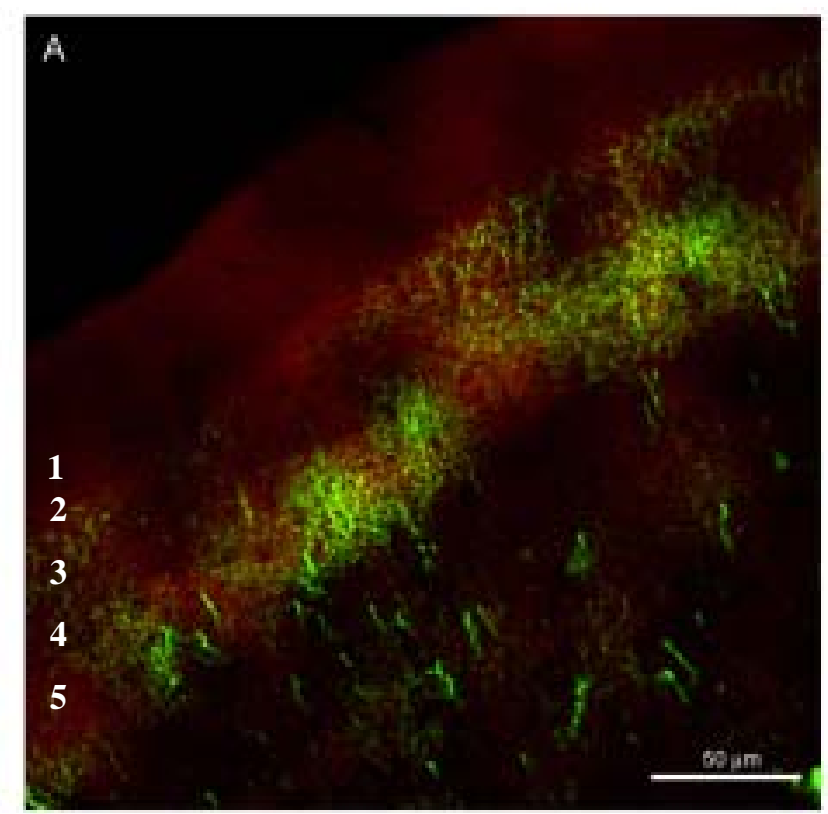

Biocitina + mGluR2/3

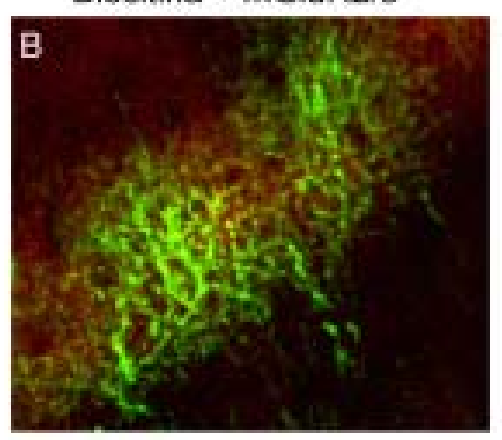

Biocitina

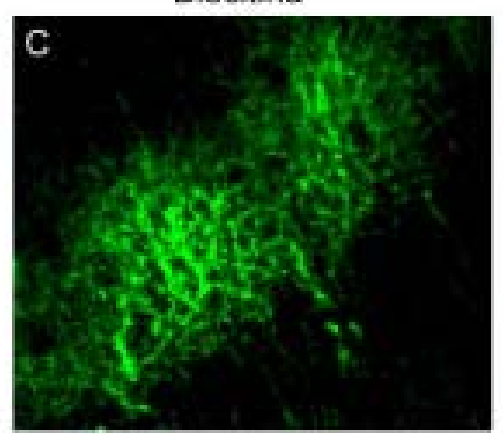

mGlu2/3

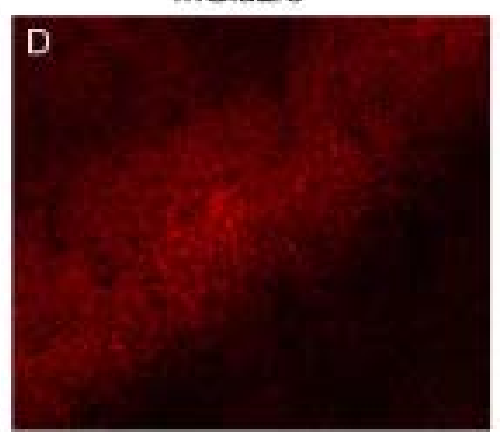

Figura 55. Imagens digitais de cortes coronais de encéfalo de pintos sem enucleação ocular, ilustrando o padrão de marcação para mGluR2/3 (em vermelho) na camada $5 b$ do tecto óptico e das aferências do Ipc (em verde). Em A mostra a imunorreatividade para mGluR $2 / 3$ e os terminais provenientes do Ipc nas camadas superficiais do $\mathrm{TeO}(2,3,4,5)$. Em B podemos observar raros pontos de co-localização com os terminais $(\mathrm{C})$ e em $\mathrm{D}$, os aglomerados de neurópila nas camadas 5 e 6. 


\subsection{RESUMO dOS RESULTAdOS PARA O TECTO ÓPTICO}

Tabela 5. Resultados resumidos das análises da expressão protéica e da imunorreatividade para mGluR1, mGluR2/3 e mGluR5 no TeO de pintos no $1^{\circ}, 7^{\circ}, 15^{\circ}$ e $30^{\circ}$ dias após a enucleação ocular.

\section{Tecto Óptico}
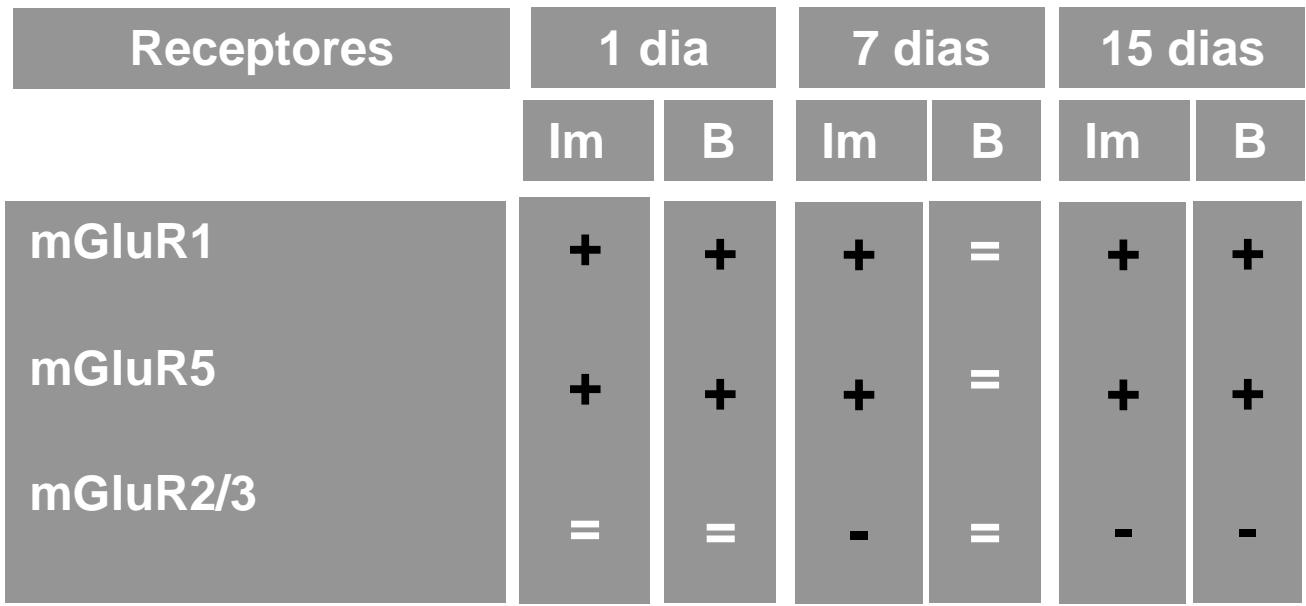

\section{0 dias}
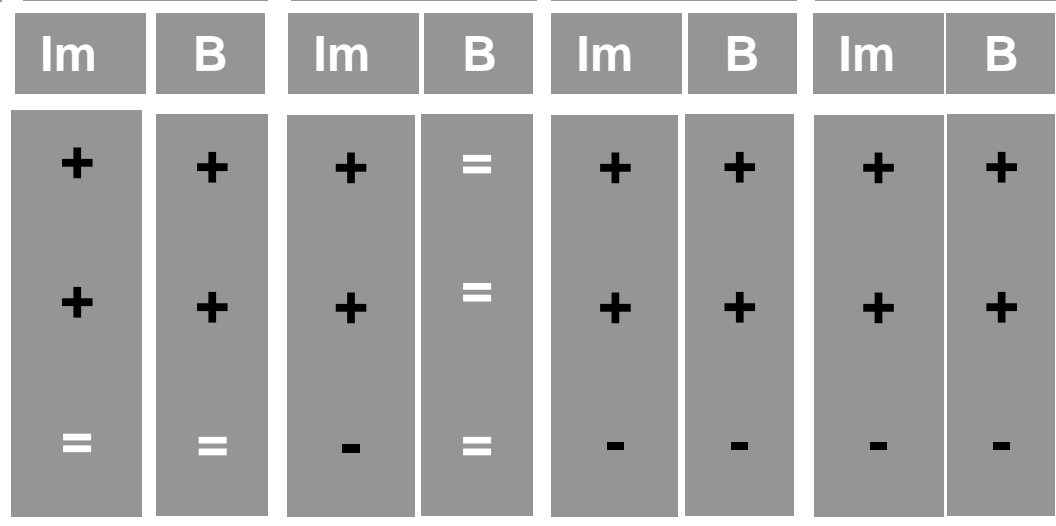

$R T=R T-P C R ; B=$ immunoblotting; Ir=imunorreatividade

= não há diferença entre o $\mathrm{TeO}$ experimental e controle; + maior intensidade de marcação na neurópila no lado experimental 


\section{DISCUSSÃo}

Os nossos resultados de imunorreatividade para mGluR1, mGluR2/3, mGluR5 e mGluR7 evidenciam a presença destes receptores em estruturas visuais primárias de ratos e pintos. Os dados podem fornecer indícios do envolvimento de alguns receptores metabotrópicos de glutamato na modulação sináptica no colículo superior de ratos e tecto óptico de pintos, visto que houve alterações na expressão destes após a enucleação ocular. Tanto a expressão diferencial dos mGluRs encontrada, quanto as alterações nos terminais no CS observadas após o uso de traçadores neuronais, nos reporta a hipótese da participação desses subtipos em processos plásticos no sistema visual. Os dados de distribuição dos mGluRs concordam com estudos que revelaram a expressão de mGluRs no colículo superior (Cirone e Salt, 2001; Cirone et al., 2002b), em núcleos talâmicos e no córtex de ratos, utilizando métodos de imuno-histoquímica e eletrofisiologia (Pin e Duvoisin, 1995; Conn e Pin, 1997; White et al., 2003) e com os realizados no TeO de pintos (Tasca et al., 1999; Zhang e Schmidt, 1999). É importante ressaltar também que a conservação de algumas funções dos sistemas de neurotransmissão em diferentes espécies, como em ratos e pintos, podem ajudar a compreender funções dos receptores glutamatérgico no processamento sináptico do sistema visual maduro com ou sem lesão, uma vez que o estímulo visual desencadeia respostas sensoriais no CS e $\mathrm{TeO}$ utilizando principalmente o glutamato como neurotransmissor (Ortega et al., 1995; Conn e Pin, 1997; Tasca et al., 1999; Cirone et al., 2002b).

Alguns estudos mostram a participação dos mGluRs em processos de neurodegeneração associados a epilepsia, em acidentes vasculares, e até mesmo em lesões, por exemplo, a enucleação ocular (Sefton et al., 1987; Kim e Jeon, 1999), podendo causar desajustes no sistema de neurotransmissão (Conn, 1994). Nestes processos, evidências da literatura atribuem ao glutamato um papel de neuromediador chave em processos de neurodegeneração, por produzir excitação e toxicidade em neurônios. A excitação excessiva, proveniente dos terminais présinápticos e dos astrócitos no espaço extracelular, pode causar então elevação de cálcio intracelular e lesão neuronal (Zipfel et al., 2000; Chong et al., 2003). Assim, há ativação de receptores, ocasionando mudanças na permeabilidade da membrana e a combinação de maior volume intracelular e um alto influxo de $\mathrm{Ca}^{++}$podem induzir 
disfunções metabólicas, perda de organelas e falência da membrana plasmática (Choi, 1988) podendo induzir a morte celular por necrose ou apoptose (Zipfel et al., 2000).

Referente ao modelo de enucleação ocular, há morte celular? A maioria dos estudos sobre enucleação ocular relacionando estudos da morfologia, densidade neuronal (Tsang, 1937), e proporção entre diferentes tipos de contato sinápticos (Lund e Lund, 1971b; a) em camadas retinorrecipientes de ratos e camundongos relatam as alterações em animais muito jovens, logo após o nascimento. Poucos relatam o efeito da degeneração transneuronal acerca do número de células nos vários centros visuais (Tsang, 1937; Lund e Lund, 1971b; a; Smith e Bedi, 1997). Outros poucos estudos evidenciaram que a neurodegeneração causada por ablação do córtex em ratos adultos induz a morte neuronal no NGLd, por provocar uma degeneração retrógrada (Lashley, 1934; Matthews, 1973). Resultados semelhantes também foram encontrados em células ganglionares da retina após axotomia do nervo óptico de ratos adultos, causando morte celular por apoptose (Lashley, 1934; Berkelaar et al., 1994; Quigley et al., 1995). Entretanto, dados de Smith \& Bedi (1997) mostraram que a enucleação em ratos adultos resultou na redução do número total de neurônios na camada SuG do colículo superior contralateral à lesão, após 60 dias de sobrevida. Esses dados sugerem que a perda de células pode estar relacionada com o tempo de sobrevida da enucleação.

Em contrapartida, nossos dados de TUNEL comprovam que não há morte celular por apoptose no CS e NGL de ratos e nem em camadas retinorrecipientes e profundas do $\mathrm{TeO}$ de pintos nos diferentes tempos de sobrevida estudados. Esses resultados sugerem que a enucleação ocular não causa perda celular nas sobrevidas estudadas, indicando que esse modelo de sistema polissináptico nos permite examinar a relação entre a função de sistemas de neuromodulação e a plasticidade neural. Além disso, a sobrevivência dos neurônios nas camadas do colículo superior após enucleação pode ser suprida por conexões sinápticas provenientes do córtex de ratos (Lund e Lund, 1971b; a; Ortega et al., 1995) e de núcleos mesencefálicos nas camadas retinorrecipientes do TeO de pintos (Morino et al., 1991), além dos próprios neurônios intrínsecos às áreas. Essa idéia pode ser apoiada no trabalho realizado por Ortega et al. (1995), que estudaram o padrão de marcação para o glutamato em camadas superficiais do colículo, que é dependente da presença dos terminais provenientes da retina e do córtex, confirmando 
resultados de trabalhos anteriores (Lund e Lund, 1971b; Mathers, 1977; Hofbauer e Hollander, 1986). Eles fizeram enucleação ocular por aspiração e observaram que a lesão, após 10 dias, provocou uma redução da imunorreatividade para glutamato em terminais das camadas superficiais no colículo superior. A lesão dupla com ablação cortical mostrou que há uma perda maciça dos terminais imunorreativos para glutamato nas camadas Zo, SuG e Op, demonstrando que essas aferências são as grandes fontes de glutamato.

Outra característica que pode ser observada na axotomia, nesse caso a enucleação ocular, é a degeneração de fibras provenientes das projeções retinianas em estruturas visuais primárias. Estudos de identificação de neurotransmissores envolvidos na degeneração de fibras eferentes do CS e NGL de ratos no modelo de enucleação ocular demonstraram que há degeneração axonal e perda de terminais axonais. No aspecto histológico, ocorre perda de fibras mielinizadas do trato óptico e perda de terminais axonais no CS e NGLd contralateral de ratos após 10 dias de sobrevida (Lund, 1972; Lund e Cunningham, 1972). Gray e Hamlyn (1962), em pesquisas com microscopia eletrônica, analisaram as características sinápticas no TeO de pintos nos dias 3, 6, 7 e 30 dias após enucleação ocular. Eles observaram que há degeneração de axônios retinianos e dos seus terminais e que as mudanças na orientação dos neurofilamentos, no arranjo da mielina e na degeneração mitocondrial vão acontecendo progressivamente com o tempo da lesão. No trigésimo dia há mudanças drásticas praticamente em todos axônios mielinizados do trato óptico nas camadas retinorrecipientes. Há uma perda de neurofilamentos e a superfície da membrana pré-sináptica não é mais distinguível. Já na membrana póssináptica ocorre mudança em sua espessura quando há uma substituição dos terminais pré-sinápticos por glia, sugerindo assim mudanças transneuronais. Essas observações suportam os nossos dados revelados com Fluoro-Jade B, com o qual observamos degeneração dos terminais axonais nas camadas superficiais do CS, de fibras do nervo óptico e poucos terminais nas camadas superficiais do TeO de pintos. As mudanças ocorreram também em terminais da via córtico-colicular com o aumento de fibras nas camadas SuG e Op do CS após injetarmos o BDA, levantando indícios da plasticidade neuronal após e enucleação ocular.

A axotomia não só provoca reações em neurônios como também em células gliais. A função da glia, por muito tempo, restringiu-se à nutrição, sustentação e proteção, mas atualmente as células gliais reconhecidamente participam da 
comunicação neuronal (Tsacopoulos, 2002). Vários estudos têm descrito que cicatrizes gliais não são permissivas para o crescimento axonal (Hatten et al., 1991; Giulian e Corpuz, 1993), e que durante o desenvolvimento os astrócitos guiam a migração neuronal e axonal (Shao e Mccarthy, 1994). As respostas gliais a lesões parecem ser heterogêneas, dependendo da área afetada e do tipo e intensidade da lesão (Lenz et al., 1997). Astrócitos podem apresentar alterações morfológicas, como aumento no tamanho e na quantidade de processos. Niquet et al. (1994) mostraram que astrócitos presentes em regiões que apresentam intensa morte neuronal apresentaram proliferação e hipertrofia, enquanto que astrócitos presentes em regiões de pouca morte neuronal somente apresentaram alterações hipertróficas.

Além disso, a organização glial pode sofrer alterações também por lesões que ocorram em regiões do sistema nervoso, a exemplo do nosso modelo. Essa reação permite observarmos também a extensão da neurodegeneração causada em áreas visuais. Em nossos dados observamos um aumento da imunorreatividade para GFAP no colículo superior causada pela enucleação ocular, sendo que esse processo aumentou proporcionalmente aos tempos de sobrevidas estudados. Nossos dados estão de acordo com o trabalho de Sefton (1969), em que é observado também uma aumento de GFAP no CS em 1, 2 e 8 dias pós-lesão. Esse aumento pode indicar que há uma proliferação de células gliais no colículo superior ocasionado pela enucleação ocular e uma indicação que está ocorrendo o estabelecimento de outros contatos sinápticos, ajustes metabólicos nas células e ajustes no sistema de neurotransmissão glutamatérgica. Os mecanismos pelos quais lesões em axônios levam à ativação de células gliais ainda são pouco claros. Uma hipótese de Aldskogius e Kozlova (1998) sugere que neurônios do sistema nervoso periférico lesados interajam com astrócitos adjacentes e as respostas gliais sejam amplificadas por mecanismos parácrinos e autócrinos, envolvendo a presença de citocinas, conexinas e receptores de glutamato. Essas propriedades funcionais de ativação glial podem determinar sua influência na sobrevivência neuronal, regeneração axonal e plasticidade sináptica.

As alterações que ocorrem não só na morfologia de neurônios e células gliais, mas também em sua função, podem ser observadas nas modificações nos sistemas de neurotransmissão após a enucleação ocular. De fato, os terminais retinianos e terminais corticais utilizam o glutamato como neurotransmissor. Estudos demonstram que a ablação cortical e lesão unilateral da retina diminuem 
drasticamente os níveis de glutamato nos terminais axonais e corticais no CS após 10 dias de sobrevida (Sakurai et al., 1990; Ortega et al., 1995). Outros trabalhos evidenciam a diminuição da liberação de glutamato no $4^{\circ}$ dia pós lesão, porém os níveis são normalizados após o $7^{0}$ dia pós-lesão ( $\mathrm{Li}$ et al., 1996). Baseados em dados da literatura, em fases iniciais da enucleação ocular pode haver uma intensa liberação de glutamato nos terminais em degeneração nas camadas superficiais do colículo superior (Choi, 1988, Pires et al., 1998). Essa maciça liberação pode induzir mudanças nas vias transcricionais e metabólicas das células pós-sinápticas (Choi, 1988; Pires et al., 1998).

Em trabalhos anteriores do laboratório, foi avaliado o efeito da lesão retiniana sobre a plasticidade de receptores de glutamato. A expressão dos receptores ionotrópicos de glutamato do tipo AMPA sofrem um efeito bifásico após a lesão. As subunidades GluR1 e GluR2/3 diminuíram até dois dias após a enucleação no lado experimental do $\mathrm{TeO}$ de pintos. Após $07^{\circ}$ dia houve um aumento na expressão dessas subunidades (Pires et al., 1998). Em ratos, foi observado também uma expressão diferencial dessas subunidades (Batista, 2006) e da enzima de síntese do óxido nítrico no CS e NGLd após enucleação ocular (Batista, 2006; Chacur et al., 2006). Em experimentos com lesão dupla, ablação cortical e enucleação ocular, os níveis de expressão diminuíram no CS de ratos (Batista, 2006) e camundongos (Brito, 2006). A modulação diferencial dos receptores ionotrópicos de glutamato e de outros moduladores após ter sido removido o aporte glutamatérgico em animais adultos pode sugerir a participação desses subtipos no restabelecimento de conexões sinápticas após a lesão no sistema visual. Ainda, pode ser feita uma correlação com a consolidação sináptica durante o desenvolvimento, onde ocorre uma intensa plasticidade neuronal, porém sem processos típicos desse período, como a apoptose. Além disso, nossos dados sugerem uma modulação feita também por sinapses consideradas mais lentas, que envolve uma ativação de segundos mensageiros, os mGluRs, e interação com os outros receptores de glutamato e de outros neurotransmissores.

Os nossos resultados de RT-PCR em tempo real, immunoblotting e imunohistoquímica demonstraram que houve uma resposta à enucleação. Levando em consideração o fato de haver uma intensa liberação de glutamato nas fases iniciais da lesão, isso pode ter acarretado a ativação dos mGluRs. Essa indução pode ter ativado vias de sinalização e provocado uma mudança na transcrição gênica da 
célula, aumentando a expressão do gene mGluR1 já no 1ํ dia pós-lesão, mantendo esses níveis nas outras sobrevidas estudadas. Para o outro subtipo do grupo I, o mGluR5, só houve aumento em sua expressão gênica no $30^{\circ}$ dia. Entretanto os níveis protéicos e a imunorreatividade foram aumentadas antes desse período. Essas diferenças entre a expressão gênica e protéica podem ser explicadas pela possível estabilidade diferente dos mRNA e na eficiência da tradução para esses genes, como talvez por outros mecanismos transcricionais e ou translacionais. Mesmo que esses genes pertençam à mesma família, eles podem exercer funções celulares distintas, e até mesmo em processos patológicos podem atuar diferentemente (Kihara et al., 2005; Striedinger et al., 2005; Chacur et al., 2006). Além disso, as diferenças encontradas entre a expressão dos mRNA e a presença de imunorreatividade das suas proteínas correspondentes no CS, como para mGluR1, mGluR5 e mGluR2/3, sugerem que os níveis de mRNA podem não refletir a presença funcional do produto protéico.

A ativação de vias de sinalização que envolve os mGluRs do grupo I e os fatores de transcrição desempenha uma importante função no controle da excitação celular. Uma vez ativo, em resumo, os mGluRs do grupo I ativam segundos mensageiros como trifosfato inositol $\left(\mathrm{IP}_{3}\right)$ e induzem a mobilização de $\mathrm{Ca}^{++}$ intracelular; entretanto, há uma diferença na cinética entre os dois subtipos. $O$ mGluR1 induz simples picos de resposta ao $\mathrm{Ca}^{++}$, mas a ativação de mGluR5 promove aumentos oscilatórios de $\mathrm{Ca}^{++}$citosólico livre, ambos dependentes da fosforilação de PKC (Kawabata et al., 1996). A função de cada subtipo pode ter atuações distintas em cada período da lesão para que possam atuar na reorganização sináptica, talvez inibindo outros processos lesivos para a célula, ou auxiliando outros mecanismos de plasticidade.

Outro ponto importante é a localização dos mGluRs do grupo I, que podem estar presentes em terminais sinápticos, principalmente, podendo assim regular a liberação de transmissores excitatórios (Flor et al., 2002). Embora não tenhamos analisado vias de proteção neuronal, o aumento observado na imunorreatividade nas camadas retinorrecipientes tanto do CS e TeO pode sugerir uma forma de proteção neuronal, suprimindo assim a excitabilidade neuronal e impedindo possíveis lesões em células vizinhas. As funções do grupo I em processos neurodegenerativos ainda são controversas. Na literatura, alguns trabalhos demonstraram neurotoxicidade após injeção de agonista do grupo I, o 1S,3R-1- 
amino-ciclopentil-1,3-dicarboxilato, no hipocampo de ratos adultos (Mcdonald e Schoepp, 1992; Sacaan e Schoepp, 1992). Em contraste, esse agonista reduziu a morte celular induzida por NMDA em culturas corticais (Opitz e Reymann, 1993; Pizzi et al., 1996a; Pizzi et al., 1996b; Schroder et al., 1999). No estudo de Watanabe et al. (2002) mostrou-se que a ativação do grupo I pode suprimir a excitação através de inibição da liberação de glutamato em células do hipocampo. É importante ressaltar que a proteção celular via ativação do sistema de mGluRs vai depender da natureza e extensão da lesão, bem como o estado da célula para determinar se ocorrerá ativação ou inibição desses receptores (Maiese et al., 2005).

Interessante observar que resultados semelhantes dos níveis protéicos para o grupo I após a enucleação ocular são conferidos nos nossos resultados no TeO de pintos, sugerindo que esse grupo pode exercer a mesma função em espécies diferentes.

Em contrapartida, a expressão gênica para o grupo II dos mGluRs não apresentou regulação do gene mGluR2, nos tempos avaliados. Porém houve uma diminuição da expressão para o gene mGluR3, apenas nos $1^{\circ}$ e $7^{\circ}$ dias pós-lesão no CS de ratos, voltando aos níveis normais nos outros tempos de sobrevida. Verificamos também que a expressão protéica de mGluR2/3 após a enucleação ocular foi menor no TeO de pintos e inalterada no colículo superior. Um estudo da literatura relata que há redução da imunorreatividade para mGluR2/3 entre 20 e 60 dias pós-lesão no colículo superior de camundongos (Kim e Jeon, 1999). A diminuição da expressão gênica em fases iniciais da lesão pode ser resultado da interrupção do metabolismo e/ou atrofia das células em contato com terminais retinianos em degeneração. Além disso, consideramos o fato que há perda da maquinaria protéica, como fatores de transcrição, das aferências retinianas e perda do aporte protéico nos terminais neuronais em degeneração no colículo superior. Por exemplo, remoção unilateral de áreas corticais visuais leva a redução de glutamato na neurópila e pericários no CS de gatos, provavelmente interferindo em processos neuroquímicos das células do CS (Jeon et al., 1997a; Jeon et al., 1997b).

Entre os mGluRs, os receptores dos grupos II e III atuam em terminais présinápticos, principalmente, e diminuem a liberação de glutamato dependente de $\mathrm{Ca}^{2+}$, sendo também considerados como neuroprotetores. A ativação do grupo II, similarmente, pode inibir a liberação de glutamato no giro denteado através de mecanismos que envolvem canais voltagem-dependentes de cálcio em terminais 
pré-sinápticos (Dietrich et al., 2002). Bruno et al. (1997) sugeriram que o papel desses receptores contra a excitoxicidade induzida por NMDA requer a síntese de novas proteínas e envolve também uma interação entre neurônio e glia e, portanto, a atuação do subtipo mGluR3 que está presente em astrócitos (Flor et al., 2002). Além disso, o acúmulo de glutamato extracelular em tecido isquêmico é causado em parte por regulação negativa de transportadores de glutamato (Calabresi et al., 2000). Isso sugere que mecanismos de ação pré-sináptica dos mGluRs podem limitar sua efetividade como neuroprotetores. Entretanto, a liberação excessiva de glutamato na fenda sináptica após a degeneração pelos terminais axonais da retina pode interferir na regulação celular desses receptores, impedindo inicialmente que ele tenha uma função neuroprotetora.

Comparado a outros subtipos de mGluRs, a afinidade do glutamato pelos receptores mGluR7, do grupo III, é relativamente baixa. Isso sugere que o mGluR7 é ativado com altas concentrações de glutamato, que podem ser causadas, por exemplo, por altas freqüências de potenciais de ação (Enz, 2006). Assim, ele pode suprimir a liberação de glutamato em terminais pré-sinápticos, inibindo assim as correntes excitatórias em neurônios pós-sinápticos (Hirasawa et al., 2002; Enz, 2007). Talvez esse mecanismo possa refletir o aumento na imunorreatividade em pericários encontrado nos $1^{\circ}$ e $7^{\circ}$ dias pós-lesão, diminuindo um pouco no $15^{\circ}$ e se igualando ao controle no $30^{\circ}$ dia. Tanto a sua expressão gênica como a protéica refletiram esse aumento observado nos pericários nas camadas superficiais do colículo superior.

As quantificações analisadas com 0 método de immunoblotting $\mathrm{e}$ imunorreatividade para a expressão dos mGluRs no colículo superior de ratos e no TeO de pintos confirmaram a expressão diferencial também da proteína. Com os dados da expressão protéica para os grupos I e III, observamos um aumento nas sobrevidas estudadas, exceto do grupo III em pintos, onde não encontramos imunorreatividade para mGluR7. Em ratos, esses aumentos foram em estágios iniciais à lesão para o mGluR7 e para mGluR1 e mGluR5 em estágios iniciais e tardios da lesão. Nesse último caso, incluímos também os resultados obtidos no $\mathrm{TeO}$ de pintos. No grupo II, por outro lado, não houve diferença no rato, porém houve diminuição no $15^{\circ}$ e $30^{\circ}$ dias pós-lesão. Considerando que os subtipos de mGluRs podem exercer uma função mais excitatória ou inibitória nas sinapses e que essa regulação diferencial foi observada em fases distintas da lesão, podemos inferir que 
os subtipos ditos inibitórios podem atuar mais em estágios iniciais da lesão. Nesse caso seria o mGluR7 que inibe a produção de AMPc, atenuando assim a disparos excitatórios nas células envolvidas na lesão. Os níveis gênicos e protéicos diminuídos podem estar ligados à degeneração dos terminais que os contêm. Em contrapartida, os considerados mais excitatórios, no caso o mGluR1 e mGluR5, teriam uma maior atuação em estágios mais tardios da lesão, provavelmente incidindo mais na reorganização sináptica de longo prazo.

Alguns aspectos da plasticidade neuronal e outros rearranjos sinápticos podem ser observado nos resultados com mGluR2/3 no TeO de pintos. O aspecto em grumos da marcação na camada 5 foi remodelada após a enucleação ocular, apareceram mais contínuas ao longo da camada. Isso pode sugerir que as fibras que anteriormente faziam sinapses com os as projeções provenientes da retina refizeram sua organização sináptica. A identificação desses terminais não foi resolvida com os nossos dados com biocitina, uma vez que a co-localização do mGluR2/3 e terminais do Ipc e Imc não foram observadas no TeO de pintos. Pode ser que esses terminais sejam de células oriundas das camadas mais profundas do TeO.

É importante ressaltar que há raros trabalhos na literatura envolvendo os receptores de glutamato no encéfalo de pintos. A maioria dos trabalhos, que envolve a enucleação ocular em ratos, foi realizado durante o desenvolvimento, e as possíveis variações produzidas, aparentemente, podem ser mais facilmente detectadas nesse modelo. Embora a variação da expressão de receptores possam ser menos evidentes em animais adultos, essa regulação na expressão dos receptores, ou seja, a plasticidade neuronal, pode ser observada em nossos dados, bem como em trabalhos anteriores do nosso laboratório.

A análise da imunorreatividade para mGluRs no complexo geniculado lateral do tálamo indicou que não houve alteração nesse complexo nuclear após enucleação ocular em nenhum dos tempos de sobrevidas estudados. Uma das explicações para esse resultado é o fato de anatomicamente a via retino-talâmica ser distribuída em proporções menores quando comparado à via retino-colicular em roedores. Em ratos, cerca de $65 \%$ das projeções retinianas se direcionam para 0 colículo superior e 15\% vão para o núcleo geniculado talâmico (Sefton et al., 1987). Dessa forma, a degeneração que ocorre nos terminais axonais da retina no núcleo geniculado podem exercer uma menor influência na expressão dos mGluRs nessa 
estrutura, apesar de ela conter mGluRs em interneurônios do núcleo geniculado lateral dorsal modulando a retransmissão no tálamo (Govindaiah e Cox, 2006). Ainda há raros trabalhos demonstrando a presença destes receptores no NGL. A ausência da interferência da enucleação ocular sobre os receptores de glutamato, ionotrópicos foi detectada em estudos semelhantes no NGL de camundongos (Brito, 2006).

Porém, considerando outros tipos de receptores ou enzimas, essa influência pode ser maior, a exemplo do trabalho de Batista (2006), que mostrou que há diminuição da subunidade GluR1 do tipo AMPA após enucleação ocular no NGLd de ratos. Outros estudos, com lesão dupla, ablação cortical e lesão retiniana, demontram diminuição da enzima de síntese do glutamato no NGLd de gatos (Arckens et al., 1998) e macacos adultos (Hendry, 1991), como também observaram alterações em proteínas associadas ao crescimento encontradas em neurônios, GAP-43, e proteínas sinápticas, demonstrando que há uma reorganização sináptica no NGLd de gatos adultos (Baekelandt et al., 1994).

Apesar de não haver morte celular por apoptose no colículo superior nos tempos de sobrevidas estudados neste trabalho e nem termos avaliado os efeitos da enucleação sobre eventos da neuroproteção, podemos sugerir que os mGluRs podem ter participação nesse processo, uma vez que a ativação desses receptores pode ativar segundos mensageiros que estão envolvidos no processo de proteção celular, inibindo vias que vão ativar caspases, por exemplo (Maiese et al., 2005). Sabe-se que níveis moderados de agonistas de receptores de glutamato podem proteger neurônios de danos causados por excitotoxicidade. Estudos recentes mostram que a estimulação dos mGluRs é crucial para a neuroproteção, particularmente contra a morte celular em um tecido isquêmico (Sagara e Schubert, 1998; Kalda et al., 2000) e contra vários tipos de lesão celular, como trauma, por exemplo (Vos et al., 2000).

Em vista da localização dos receptores (pré- e pós sinápticos), sua função fisiológica (inibição ou excitação), sua influência em eventos transsinápticos e a interação com outros moduladores mediante uma lesão, observa-se a complexidade dos ajustes necessários para promover a reorganização sináptica. Não podemos deixar de ressaltar que a modulação que ocorre nesse processo de lesão pode interferir também em outros sistemas de neurotransmissão. Muitas moléculas neuroativas estão associadas aos circuitos intrínsecos e extrínsecos do CS de 
mamíferos e TeO de pintos, e toda a influência da complexidade vísuo-motora provavelmente provém da modulação dessas substâncias. Assim, o sistema dos mGluRs pode influenciar outros moduladores, assim como pode sofrer modulação por outros sistemas (Harvey et al., 2001).

Não podemos também excluir a possibilidade de que essas mudanças podem ser influenciadas também por fatores neurotróficos, mas são necessários outros trabalhos para avaliar esses aspectos.

Assim, apesar de haver poucos trabalhos na literatura envolvendo enucleação monocular e expressão dos receptores metabotrópicos de glutamato no sistema visual em animais adultos, os nossos resultados podem indicar uma importante função dos mGluRs na plasticidade neuronal e auxiliar no esclarecimento dos mecanismos envolvidos em processos de lesão desse sistema. Os dados obtidos no TeO de pintos sugere ainda que algumas funções dos sistemas desses receptores foram conservados, auxiliando na compreensão da plasticidade sináptica após uma lesão central. 


\section{Conclusões}

Diante dos resultados obtidos nesse trabalho podemos concluir que:

- Há expressão de vários subtipos de receptores metabotrópicos de glutamato no colículo superior, núcleo geniculado lateral de ratos e tecto óptico de pintos;

- Não detectamos morte celular por apoptose nas estruturas visuais primárias do rato e pintos em nenhum tempo de sobrevida estudado;

- Observamos fibras em degeneração em tempos de sobrevidas a partir do sétimo dia após enucleação ocular;

- Houve aumento da gliose reativa nas áreas atingidas pela enucleação ocular progressivamente ao tempo de lesão;

- Não encontramos uma regulação protéica diferencial dos receptores metabotrópicos de glutamato núcleo geniculado lateral após enucleação ocular;

- Encontramos uma regulação gênica e protéica diferencial dos receptores metabotrópicos de glutamato no colículo superior e tecto óptico após enucleação ocular em todos os tempos de sobrevidas avaliados. 


\section{REFERÊNCIAS BIBLIOGRÁFICAS}

Abe, T.; Sugihara, H.; Nawa, H.; Shigemoto, R.; Mizuno, N. e Nakanishi, S. Molecular characterization of a novel metabotropic glutamate receptor mGluR5 coupled to inositol phosphate/Ca2+ signal transduction. J Biol Chem, v.267, n.19, p.13361-8, 1992.

Aiba, A.; Kano, M.; Chen, C.; Stanton, M.E.; Fox, G.D.; Herrup, K.; Zwingman, T.A. e Tonegawa, S. Deficient cerebellar long-term depression and impaired motor learning in mGluR1 mutant mice. Cell, v.79, n.2, p.377-88, 1994.

Al-Abdulla, N.A.; Portera-Cailliau, C. e Martin, L.J. Occipital cortex ablation in adult rat causes retrograde neuronal death in the lateral geniculate nucleus that resembles apoptosis. Neuroscience, v.86, n.1, p.191-209, 1998.

Aldskogius, H. e Kozlova, E.N. Central neuron-glial and glial-glial interactions following axon injury. Prog Neurobiol, v.55, n.1, p.1-26, 1998.

Allen, J.W.; Ivanova, S.A.; Fan, L.; Espey, M.G.; Basile, A.S. e Faden, A.I. Group II metabotropic glutamate receptor activation attenuates traumatic neuronal injury and improves neurological recovery after traumatic brain injury. J Pharmacol Exp Ther, v.290, n.1, p.112-20, 1999.

Altinbilek, B. e Manahan-Vaughan, D. Antagonism of group III metabotropic glutamate receptors results in impairment of LTD but not LTP in the hippocampal CA1 region, and prevents long-term spatial memory. Eur J Neurosci, v.26, n.5, p.1166-72, 2007.

Anwyl, R. Metabotropic glutamate receptors: electrophysiological properties and role in plasticity. Brain Res Brain Res Rev, v.29, n.1, p.83-120, 1999.

Aramori, I. e Nakanishi, S. Signal transduction and pharmacological characteristics of a metabotropic glutamate receptor, mGluR1, in transfected $\mathrm{CHO}$ cells. Neuron, v.8, n.4, p.75765, 1992.

Arckens, L.; Eysel, U.T.; Vanderhaeghen, J.J.; Orban, G.A. e Vandesande, F. Effect of sensory deafferentation on the GABAergic circuitry of the adult cat visual system. Neuroscience, v.83, n.2, p.381-91, 1998.

Awad, H.; Hubert, G.W.; Smith, Y.; Levey, A.I. e Conn, P.J. Activation of metabotropic glutamate receptor 5 has direct excitatory effects and potentiates NMDA receptor currents in neurons of the subthalamic nucleus. J Neurosci, v.20, n.21, p.7871-9, 2000.

Baekelandt, V.; Arckens, L.; Annaert, W.; Eysel, U.T.; Orban, G.A. e Vandesande, F. Alterations in GAP-43 and synapsin immunoreactivity provide evidence for synaptic reorganization in adult cat dorsal lateral geniculate nucleus following retinal lesions. Eur $\mathrm{J}$ Neurosci, v.6, n.5, p.754-65, 1994.

Bahn, S.; Volk, B. e Wisden, W. Kainate receptor gene expression in the developing rat brain. J Neurosci, v.14, n.9, p.5525-47, 1994.

Baskys, A. Metabotropic receptors and 'slow' excitatory actions of glutamate agonists in the hippocampus. Trends Neurosci, v.15, n.3, p.92-6, 1992. 
Baskys, A. e Malenka, R.C. Agonists at metabotropic glutamate receptors presynaptically inhibit EPSCs in neonatal rat hippocampus. J Physiol, v.444, p.687-701, 1991.

Batista, S.S. Moléculas relacionadas com neuroproteção e neurodegeneração no sistema visual: efeitos de lesões periféricas e centrais. Fisiologia e Biofísica, Univesidade de São Paulo, São Paulo, 2006. 149 p.

Bear, M.F.; Huber, K.M. e Warren, S.T. The mGluR theory of fragile $X$ mental retardation. Trends Neurosci, v.27, n.7, p.370-7, 2004.

Beckstead, R.M. e Frankfurter, A. A direct projection from the retina to the intermediate gray layer of the superior colliculus demonstrated by anterograde transport of horseradish peroxidase in monkey, cat and rat. Exp Brain Res, v.52, n.2, p.261-8, 1983.

Belmonte, M.A.; Santos, M.F.; Kihara, A.H.; Yan, C.Y. e Hamassaki, D.E. Light-Induced photoreceptor degeneration in the mouse involves activation of the small GTPase Rac1. Invest Ophthalmol Vis Sci, v.47, n.3, p.1193-200, 2006.

Bergles, D.E.; Roberts, J.D.; Somogyi, P. e Jahr, C.E. Glutamatergic synapses on oligodendrocyte precursor cells in the hippocampus. Nature, v.405, n.6783, p.187-91, 2000.

Berkelaar, M.; Clarke, D.B.; Wang, Y.C.; Bray, G.M. e Aguayo, A.J. Axotomy results in delayed death and apoptosis of retinal ganglion cells in adult rats. J Neurosci, v.14, n.7, p.4368-74, 1994.

Bettler, B.; Boulter, J.; Hermans-Borgmeyer, I.; O'shea-Greenfield, A.; Deneris, E.S.; Moll, C.; Borgmeyer, U.; Hollmann, M. e Heinemann, S. Cloning of a novel glutamate receptor subunit, GluR5: expression in the nervous system during development. Neuron, v.5, n.5, p.583-95, 1990.

Bettler, B.; Egebjerg, J.; Sharma, G.; Pecht, G.; Hermans-Borgmeyer, I.; Moll, C.; Stevens, C.F. e Heinemann, S. Cloning of a putative glutamate receptor: a low affinity kainate-binding subunit. Neuron, v.8, n.2, p.257-65, 1992.

Bettler, B. e Mulle, C. Review: neurotransmitter receptors. II. AMPA and kainate receptors. Neuropharmacology, v.34, n.2, p.123-39, 1995.

Blackstone, C.D.; Levey, A.I.; Martin, L.J.; Price, D.L. e Huganir, R.L. Immunological detection of glutamate receptor subtypes in human central nervous system. Ann Neurol, v.31, n.6, p.680-3, 1992.

Bonci, A.; Grillner, P.; Siniscalchi, A.; Mercuri, N.B. e Bernardi, G. Glutamate metabotropic receptor agonists depress excitatory and inhibitory transmission on rat mesencephalic principal neurons. Eur J Neurosci, v.9, n.11, p.2359-69, 1997.

Bond, A.; Jones, N.M.; Hicks, C.A.; Whiffin, G.M.; Ward, M.A.; O'neill, M.F.; Kingston, A.E.; Monn, J.A.; Ornstein, P.L.; Schoepp, D.D.; Lodge, D. e O'neill, M.J. Neuroprotective effects of LY379268, a selective mGlu2/3 receptor agonist: investigations into possible mechanism of action in vivo. J Pharmacol Exp Ther, v.294, n.3, p.800-9, 2000.

Bond, A.; O'neill, M.J.; Hicks, C.A.; Monn, J.A. e Lodge, D. Neuroprotective effects of a systemically active group II metabotropic glutamate receptor agonist LY354740 in a gerbil model of global ischaemia. Neuroreport, v.9, n.6, p.1191-3, 1998. 
Boulter, J.; Hollmann, M.; O'shea-Greenfield, A.; Hartley, M.; Deneris, E.; Maron, C. e Heinemann, S. Molecular cloning and functional expression of glutamate receptor subunit genes. Science, v.249, n.4972, p.1033-7, 1990.

Bradford, M.M. A rapid and sensitive method for the quantitation of microgram quantities of protein utilizing the principle of protein-dye binding. Anal Biochem, v.72, p.248-54, 1976.

Brandstatter, J.H.; Koulen, P.; Kuhn, R.; Van Der Putten, H. e Wassle, H. Compartmental localization of a metabotropic glutamate receptor (mGluR7): two different active sites at a retinal synapse. J Neurosci, v.16, n.15, p.4749-56, 1996.

Brauer, K.; Schober, W. e Winkelmann, E. Two morphologically different types of retinal axon terminals in the rat's dorsal lateral geniculate nucleus and their relationships to the $\mathrm{X}$ - and $\mathrm{Y}$ channel. Exp Brain Res, v.36, n.3, p.523-32, 1979.

Brito, I. Expressão dos receptores de glutamato nos sistema visual: efeitos da desaferentação glutamatérgica. Departamento de Fisiologia e Biofísica, Universidade de São Paulo, São Paulo, 2006. 75 p.

Brown, T.M.; Brotchie, J.M. e Fitzjohn, S.M. Cannabinoids decrease corticostriatal synaptic transmission via an effect on glutamate uptake. J Neurosci, v.23, n.35, p.11073-7, 2003.

Bruno, V.; Battaglia, G.; Copani, A.; Casabona, G.; Storto, M.; Di Giorgi Gerevini, V.; Ngomba, R. e Nicoletti, F. Metabotropic glutamate receptors and neurodegeneration. Prog Brain Res, v.116, p.209-21, 1998.

Bruno, V.; Battaglia, G.; Ksiazek, I.; Van Der Putten, H.; Catania, M.V.; Giuffrida, R.; Lukic, S.; Leonhardt, T.; Inderbitzin, W.; Gasparini, F.; Kuhn, R.; Hampson, D.R.; Nicoletti, F. e Flor, P.J. Selective activation of mGlu4 metabotropic glutamate receptors is protective against excitotoxic neuronal death. J Neurosci, v.20, n.17, p.6413-20, 2000.

Bruno, V.; Copani, A.; Knopfel, T.; Kuhn, R.; Casabona, G.; Dell'albani, P.; Condorelli, D.F. e Nicoletti, F. Activation of metabotropic glutamate receptors coupled to inositol phospholipid hydrolysis amplifies NMDA-induced neuronal degeneration in cultured cortical cells. Neuropharmacology, v.34, n.8, p.1089-98, 1995.

Bruno, V.; Sureda, F.X.; Storto, M.; Casabona, G.; Caruso, A.; Knopfel, T.; Kuhn, R. e Nicoletti, F. The neuroprotective activity of group-II metabotropic glutamate receptors requires new protein synthesis and involves a glial-neuronal signaling. J Neurosci, v.17, n.6, p.1891-7, 1997.

Buisson, A. e Choi, D.W. The inhibitory mGluR agonist, S-4-carboxy-3-hydroxyphenylglycine selectively attenuates NMDA neurotoxicity and oxygen-glucose deprivationinduced neuronal death. Neuropharmacology, v.34, n.8, p.1081-7, 1995.

Bunch, S.T. e Fawcett, J.W. NMDA receptor blockade alters the topography of naturally occurring ganglion cell death in the rat retina. Dev Biol, v.160, n.2, p.434-42, 1993.

Bunt, S.M.; Lund, R.D. e Land, P.W. Prenatal development of the optic projection in albino and hooded rats. Brain Res, v.282, n.2, p.149-68, 1983.

Cajal, S.R. Histologie du système nerveux de l'homme et des vertébrés. Paris: Maloine, v.2. 1911 
Calabresi, P.; Centonze, D. e Bernardi, G. Cellular factors controlling neuronal vulnerability in the brain: a lesson from the striatum. Neurology, v.55, n.9, p.1249-55, 2000.

Calabresi, P.; Mercuri, N.B. e Bernardi, G. Activation of quisqualate metabotropic receptors reduces glutamate and GABA-mediated synaptic potentials in the rat striatum. Neurosci Lett, v.139, n.1, p.41-4, 1992.

Capogna, M. Distinct properties of presynaptic group II and III metabotropic glutamate receptor-mediated inhibition of perforant pathway-CA1 EPSCs. Eur J Neurosci, v.19, n.10, p.2847-58, 2004.

Caruso, D.M.; Owczarzak, M.T. e Pourcho, R.G. Colocalization of substance P and GABA in retinal ganglion cells: a computer-assisted visualization. Vis Neurosci, v.5, n.4, p.389-94, 1990.

Chacur, M.; Matos, R.J.; Batista, S.S.; Kihara, A.H. e Britto, L.R. Differential regulation of the neuronal isoform of nitric oxide synthase in the superior colliculus and dorsal lateral geniculate nucleus of the adult rat brain following eye enucleation. Int J Dev Neurosci, v.24, n.7, p.461-8, 2006.

Chalmers, D.T. e Mcculloch, J. Alterations in neurotransmitter receptors and glucose use after unilateral orbital enucleation. Brain Res, v.540, n.1-2, p.243-54, 1991a.

Chalmers, D.T. e Mcculloch, J. Selective alterations in glutamate receptor subtypes after unilateral orbital enucleation. Brain Res, v.540, n.1-2, p.255-65, $1991 \mathrm{~b}$.

Chan, S.L.; Furukawa, K. e Mattson, M.P. Presenilins and APP in neuritic and synaptic plasticity: implications for the pathogenesis of Alzheimer's disease. Neuromolecular Med, v.2, n.2, p.167-96, 2002.

Chang, M.L.; Wu, C.H.; Jiang-Shieh, Y.F.; Shieh, J.Y. e Wen, C.Y. Reactive changes of retinal astrocytes and Muller glial cells in kainate-induced neuroexcitotoxicity. J Anat, v.210, n.1, p.54-65, 2007.

Chang, R.S.; Tran, V.T. e Snyder, S.H. Neurotransmitter receptor localizations: brain lesion induced alterations in benzodiazepine, GABA, beta-adrenergic and histamine H1-receptor binding. Brain Res, v.190, n.1, p.95-110, 1980.

Charpak, S.; Gahwiler, B.H.; Do, K.Q. e Knopfel, T. Potassium conductances in hippocampal neurons blocked by excitatory amino-acid transmitters. Nature, v.347, n.6295, p.765-7, 1990.

Chavis, P.; Shinozaki, H.; Bockaert, J. e Fagni, L. The metabotropic glutamate receptor types 2/3 inhibit L-type calcium channels via a pertussis toxin-sensitive G-protein in cultured cerebellar granule cells. J Neurosci, v.14, n.11 Pt 2, p.7067-76, 1994.

Choi, D.W. Calcium-mediated neurotoxicity: relationship to specific channel types and role in ischemic damage. Trends Neurosci, v.11, n.10, p.465-9, 1988.

Chong, Z.Z.; Kang, J.Q. e Maiese, K. Metabotropic glutamate receptors promote neuronal and vascular plasticity through novel intracellular pathways. Histol Histopathol, v.18, n.1, p.173-89, 2003.

Chu-Wang, I.W. e Oppenheim, R.W. Cell death of motoneurons in the chick embryo spinal cord. I. A light and electron microscopic study of naturally occurring and induced cell loss during development. J Comp Neurol, v.177, n.1, p.33-57, 1978. 
Cirone, J.; Pothecary, C.A.; Turner, J.P. e Salt, T.E. Group I metabotropic glutamate receptors (mGluRs) modulate visual responses in the superficial superior colliculus of the rat. J Physiol, v.541, n.Pt 3, p.895-903, 2002a.

Cirone, J. e Salt, T.E. Physiological role of group III metabotropic glutamate receptors in visually responsive neurons of the rat superficial superior colliculus. Eur J Neurosci, v.12, n.3, p.847-55, 2000.

Cirone, J. e Salt, T.E. Group II and III metabotropic glutamate receptors contribute to different aspects of visual response processing in the rat superior colliculus. J Physiol, v.534, n.Pt 1, p.169-78, 2001.

Cirone, J.; Sharp, C.; Jeffery, G. e Salt, T.E. Distribution of metabotropic glutamate receptors in the superior colliculus of the adult rat, ferret and cat. Neuroscience, v.109, n.4, p.779-86, 2002b.

Coleman, J. e Clerici, W.J. Extrastriate projections from thalamus to posterior occipitaltemporal cortex in rat. Brain Res, v.194, n.1, p.205-9, 1980.

Collingridge, G.L. e Singer, W. Excitatory amino acid receptors and synaptic plasticity. Trends Pharmacol Sci, v.11, n.7, p.290-6, 1990.

Congar, P.; Leinekugel, X.; Ben-Ari, Y. e Crepel, V. A long-lasting calcium-activated nonselective cationic current is generated by synaptic stimulation or exogenous activation of group I metabotropic glutamate receptors in CA1 pyramidal neurons. J Neurosci, v.17, n.14, p.5366-79, 1997.

Conn, P.J. e Pin, J.P. Pharmacology and functions of metabotropic glutamate receptors. Annu Rev Pharmacol Toxicol, v.37, p.205-37, 1997.

Conn, P.J.P., J. The metabotropic glutamate receptors. NJ. 1994

Conquet, F.; Bashir, Z.I.; Davies, C.H.; Daniel, H.; Ferraguti, F.; Bordi, F.; Franz-Bacon, K.; Reggiani, A.; Matarese, V.; Conde, F. e Et Al. Motor deficit and impairment of synaptic plasticity in mice lacking mGluR1. Nature, v.372, n.6503, p.237-43, 1994.

Conti, F.; Barbaresi, P.; Melone, M. e Ducati, A. Neuronal and glial localization of NR1 and NR2A/B subunits of the NMDA receptor in the human cerebral cortex. Cereb Cortex, v.9, n.2, p.110-20, 1999.

Cooper, B.G.; Miya, D.Y. e Mizumori, S.J. Superior colliculus and active navigation: role of visual and non-visual cues in controlling cellular representations of space. Hippocampus, v.8, n.4, p.340-72, 1998.

Copani, A.; Casabona, G.; Bruno, V.; Caruso, A.; Condorelli, D.F.; Messina, A.; Di Giorgi Gerevini, V.; Pin, J.P.; Kuhn, R.; Knopfel, T. e Nicoletti, F. The metabotropic glutamate receptor mGlu5 controls the onset of developmental apoptosis in cultured cerebellar neurons. Eur J Neurosci, v.10, n.6, p.2173-84, 1998.

Cowan, K.M. Immunochemical studies of foot-and-mouth disease. IV. Preparation and evaluation of antisera specific for virus, virus protein sub-unit and the infection-associated antigen. J Immunol, v.101, n.6, p.1183-91, 1968. 
Cowan, W.M.; Martin, A.H. e Wenger, E. Mitotic patterns in the optic tectum of the chick during normal development and after early removal of the optic vesicle. J Exp Zool, v.169, n.1, p.71-92, 1968.

Cowey, A. e Perry, V.H. The projection of the temporal retina in rats, studied by retrograde transport of horseradish peroxidase. Exp Brain Res, v.35, n.3, p.457-64, 1979.

Cunningham, T.J. e Freeman, J.A. Bilateral ganglion cell branches in the normal rat: a demonstration with electrophysiological collision and cobalt tracing methods. J Comp Neurol, v.172, n.1, p.165-75, 1977.

Cunningham, T.J. e Lund, R.D. Laminar patterns in the dorsal division of the lateral geniculate nucleus of the rat. Brain Res, v.34, n.2, p.394-8, 1971.

Curtis, D.R.; Phillis, J.W. e Watkins, J.C. The chemical excitation of spinal neurones by certain acidic amino acids. J Physiol, v.150, p.656-82, 1960.

Curtis, D.R. e Watkins, J.C. The pharmacology of amino acids related to gammaaminobutyric acid. Pharmacol Rev, v.17, n.4, p.347-91, 1965.

De Blasi, A.; Conn, P.J.; Pin, J. e Nicoletti, F. Molecular determinants of metabotropic glutamate receptor signaling. Trends Pharmacol Sci, v.22, n.3, p.114-20, 2001.

De Labra, C.; Rivadulla, C. e Cudeiro, J. Modulatory effects mediated by metabotropic glutamate receptor 5 on lateral geniculate nucleus relay cells. Eur J Neurosci, v.21, n.2, p.403-10, 2005.

Dean, P. e Redgrave, P. Superior colliculus and visual neglect in rat and hamster. III. Functional implications. Brain Res, v.320, n.2-3, p.155-63, 1984.

Dean, P.; Redgrave, P. e Lewis, G. Locomotor activity of rats in open field after microinjection of procaine into superior colliculus or underlying reticular formation. Behav Brain Res, v.5, n.2, p.175-87, 1982.

Dean, P.; Redgrave, P.; Sahibzada, N. e Tsuji, K. Head and body movements produced by electrical stimulation of superior colliculus in rats: effects of interruption of crossed tectoreticulospinal pathway. Neuroscience, v.19, n.2, p.367-80, 1986.

Debski, E.A. e Constantine-Paton, M. Evoked pre- and post-synaptic activity in the optic tectum of the cannulated tadpole. J Comp Physiol [A], v.167, n.3, p.377-90, 1990.

Decker, R.S. Retrograde responses of developing lateral motor column neurons. J Comp Neurol, v.180, n.3, p.635-60, 1978.

Defelipe, J. Types of neurons, synaptic connections and chemical characteristics of cells immunoreactive for calbindin-D28K, parvalbumin and calretinin in the neocortex. $J$ Chem Neuroanat, v.14, n.1, p.1-19, 1997.

Dietrich, D.; Kral, T.; Clusmann, H.; Friedl, M. e Schramm, J. Presynaptic group II metabotropic glutamate receptors reduce stimulated and spontaneous transmitter release in human dentate gyrus. Neuropharmacology, v.42, n.3, p.297-305, 2002.

Dingledine, R.; Boland, L.M.; Chamberlin, N.L.; Kawasaki, K.; Kleckner, N.W.; Traynelis, S.F. e Verdoorn, T.A. Amino acid receptors and uptake systems in the mammalian central nervous system. Crit Rev Neurobiol, v.4, n.1, p.1-96, 1988. 
Divac, I.; Fonnum, F. e Storm-Mathisen, J. High affinity uptake of glutamate in terminals of corticostriatal axons. Nature, v.266, n.5600, p.377-8, 1977.

Dreher, B.; Sefton, A.J.; Ni, S.Y. e Nisbett, G. The morphology, number, distribution and central projections of Class I retinal ganglion cells in albino and hooded rats. Brain Behav Evol, v.26, n.1, p.10-48, 1985.

Dube, G.R. e Marshall, K.C. Activity-dependent activation of presynaptic metabotropic glutamate receptors in locus coeruleus. J Neurophysiol, v.83, n.3, p.1141-9, 2000.

Dumas, T.C. e Foster, T.C. Development of metabotropic glutamate receptor-mediated synaptic inhibition. Neuroreport, v.8, n.13, p.2919-24, 1997.

Duvoisin, R.M.; Zhang, C.; Hamassaki-Britto, D.E. e Britto, L.R. Changes in expression of glutamate receptor subunits following photoreceptor degeneration in the rd mouse retina. Neurosci Lett, v.183, n.1-2, p.83-6, 1995a.

Duvoisin, R.M.; Zhang, C. e Ramonell, K. A novel metabotropic glutamate receptor expressed in the retina and olfactory bulb. J Neurosci, v.15, n.4, p.3075-83, 1995b.

Eaton, S.A.; Birse, E.F.; Wharton, B.; Sunter, D.C.; Udvarhelyi, P.M.; Watkins, J.C. e Salt, T.E. Mediation of thalamic sensory responses in vivo by ACPD-activated excitatory amino acid receptors. Eur J Neurosci, v.5, n.2, p.186-9, 1993.

Egebjerg, J.; Bettler, B.; Hermans-Borgmeyer, I. e Heinemann, S. Cloning of a cDNA for a glutamate receptor subunit activated by kainate but not AMPA. Nature, v.351, n.6329, p.7458, 1991.

Eldadah, B.A. e Faden, A.I. Caspase pathways, neuronal apoptosis, and CNS injury. J Neurotrauma, v.17, n.10, p.811-29, 2000.

Enz, R. The trick of the tail: protein-protein interactions of metabotropic glutamate receptors. Bioessays, v.29, n.1, p.60-73, 2007.

Esguerra, M.; Kwon, Y.H. e Sur, M. Retinogeniculate EPSPs recorded intracellularly in the ferret lateral geniculate nucleus in vitro: role of NMDA receptors. Vis Neurosci, v.8, n.6, p.545-55, 1992.

Faden, A.I.; Ivanova, S.A.; Yakovlev, A.G. e Mukhin, A.G. Neuroprotective effects of group III mGluR in traumatic neuronal injury. J Neurotrauma, v.14, n.12, p.885-95, 1997.

Fendt, M.; Koch, M. e Schnitzler, H.U. Sensorimotor gating deficit after lesions of the superior colliculus. Neuroreport, v.5, n.14, p.1725-8, 1994.

Fiorillo, C.D. e Williams, J.T. Glutamate mediates an inhibitory postsynaptic potential in dopamine neurons. Nature, v.394, n.6688, p.78-82, 1998.

Flor, P.J.; Battaglia, G. e Nico, F. Neuroprotective Activity of Metabotropic Glutamate Receptor Ligands. New Yok. 2002. 197-221 p. (Molecular and cellular biology of neuroprotection in the CNS)

Fry, F.J. e Cowan, W.M. A study of retrograde cell degeneration in the lateral mammillary nucleus of the cat, with special reference to the role of axonal branching in the preservation of the cell. J Comp Neurol, v.144, n.1, p.1-23, 1972. 
Fukuda, Y.; Sugimoto, T. e Shirokawa, T. Strain differences in quantitative analysis of the rat optic nerve. Exp Neurol, v.75, n.2, p.525-32, 1982.

Gasparini, F.; Bruno, V.; Battaglia, G.; Lukic, S.; Leonhardt, T.; Inderbitzin, W.; Laurie, D.; Sommer, B.; Varney, M.A.; Hess, S.D.; Johnson, E.C.; Kuhn, R.; Urwyler, S.; Sauer, D.; Portet, C.; Schmutz, M.; Nicoletti, F. e Flor, P.J. (R,S)-4-phosphonophenylglycine, a potent and selective group III metabotropic glutamate receptor agonist, is anticonvulsive and neuroprotective in vivo. J Pharmacol Exp Ther, v.289, n.3, p.1678-87, 1999.

Gavrieli, Y.; Sherman, Y. e Ben-Sasson, S.A. Identification of programmed cell death in situ via specific labeling of nuclear DNA fragmentation. J Cell Biol, v.119, n.3, p.493-501, 1992.

Gerber, U.; Gee, C.E. e Benquet, P. Metabotropic glutamate receptors: intracellular signaling pathways. Curr Opin Pharmacol, 2006.

Gereau, R.W.T. e Conn, P.J. Multiple presynaptic metabotropic glutamate receptors modulate excitatory and inhibitory synaptic transmission in hippocampal area CA1. J Neurosci, v.15, n.10, p.6879-89, 1995a.

Gereau, R.W.T. e Conn, P.J. Roles of specific metabotropic glutamate receptor subtypes in regulation of hippocampal CA1 pyramidal cell excitability. J Neurophysiol, v.74, n.1, p.122-9, 1995b.

Ghasemzadeh, M.B.; Sharma, S.; Surmeier, D.J.; Eberwine, J.H. e Chesselet, M.F. Multiplicity of glutamate receptor subunits in single striatal neurons: an RNA amplification study. Mol Pharmacol, v.49, n.5, p.852-9, 1996.

Gilbert, C.D. e Wiesel, T.N. Morphology and intracortical projections of functionally characterised neurones in the cat visual cortex. Nature, v.280, n.5718, p.120-5, 1979.

Ginsberg, S.D. e Martin, L.J. Axonal transection in adult rat brain induces transsynaptic apoptosis and persistent atrophy of target neurons. J Neurotrauma, v.19, n.1, p.99-109, 2002.

Giolli, R.A. e Creel, D.J. Inheritance and variability of the organization of the retinogeniculate projections in pigmented and albino rats. Brain Res, v.78, n.2, p.335-9, 1974.

Giulian, D. e Corpuz, M. Microglial secretion products and their impact on the nervous system. Adv Neurol, v.59, p.315-20, 1993.

Glaum, S.R. e Miller, R.J. Metabotropic glutamate receptors mediate excitatory transmission in the nucleus of the solitary tract. J Neurosci, v.12, n.6, p.2251-8, 1992.

Godwin, D.W.; Van Horn, S.C.; Eriir, A.; Sesma, M.; Romano, C. e Sherman, S.M. Ultrastructural localization suggests that retinal and cortical inputs access different metabotropic glutamate receptors in the lateral geniculate nucleus. J Neurosci, v.16, n.24, p.8181-92, 1996.

Gold, J.I. e Knudsen, E.I. Hearing impairment induces frequency-specific adjustments in auditory spatial tuning in the optic tectum of young owls. J Neurophysiol, v.82, n.5, p.2197209, 1999.

Goodale, M.A.; Foreman, N.P. e Milner, A.D. Visual orientation in the rat: a dissociation of deficits following cortical and collicular lesions. Exp Brain Res, v.31, n.3, p.445-57, 1978. 
Goodale, M.A. e Murison, R.C. The effects of lesions of the superior colliculus on locomotor orientation and the orienting reflex in the rat. Brain Res, v.88, n.2, p.243-61, 1975.

Govindaiah, G. e Cox, C.L. Modulation of thalamic neuron excitability by orexins. Neuropharmacology, v.51, n.3, p.414-25, 2006.

Gray, E.G. e Hamlyn, L.H. Electron microscopy of experimental degeneration in the avian optic tectum. J Anat, v.96, n.Pt 3, p.309-316 5, 1962.

Greensmith, L.; Hasan, H.I. e Vrbova, G. Nerve injury increases the susceptibility of motoneurons to $\mathrm{N}$-methyl-D-aspartate-induced neurotoxicity in the developing rat. Neuroscience, v.58, n.4, p.727-33, 1994.

Hailer, N.P.; Wirjatijasa, F.; Roser, N.; Hischebeth, G.T.; Korf, H.W. e Dehghani, F. Astrocytic factors protect neuronal integrity and reduce microglial activation in an in vitro model of $\mathrm{N}$ methyl-D-aspartate-induced excitotoxic injury in organotypic hippocampal slice cultures. Eur J Neurosci, v.14, n.2, p.315-26, 2001.

Harney, S.C.; Rowan, M. e Anwyl, R. Long-term depression of NMDA receptor-mediated synaptic transmission is dependent on activation of metabotropic glutamate receptors and is altered to long-term potentiation by low intracellular calcium buffering. J Neurosci, v.26, n.4, p.1128-32, 2006.

Hartveit, E.; Brandstatter, J.H.; Enz, R. e Wassle, H. Expression of the mRNA of seven metabotropic glutamate receptors (mGluR1 to 7) in the rat retina. An in situ hybridization study on tissue sections and isolated cells. Eur J Neurosci, v.7, n.7, p.1472-83, 1995.

Harvey, A.R.; Heavens, R.P.; Yellachich, L.A. e Sirinathsinghji, D.J. Expression of messenger RNAs for glutamic acid decarboxylase, preprotachykinin, cholecystokinin, somatostatin, proenkephalin and neuropeptide $\mathrm{Y}$ in the adult rat superior colliculus. Neuroscience, v.103, n.2, p.443-55, 2001.

Hatten, M.E.; Liem, R.K.; Shelanski, M.L. e Mason, C.A. Astroglia in CNS injury. Glia, v.4, n.2, p.233-43, 1991.

Hayhow, W.R.; Sefton, A. e Webb, C. Primary optic centers of the rat in relation to the terminal distribution of the crossed and uncrossed optic nerve fibers. J Comp Neurol, v.118, p.295-321, 1962.

Hendry, S.H. Delayed reduction in GABA and GAD immunoreactivity of neurons in the adult monkey dorsal lateral geniculate nucleus following monocular deprivation or enucleation. Exp Brain Res, v.86, n.1, p.47-59, 1991.

Hickey, T.L. e Spear, P.D. Retinogeniculate projections in hooded and albino rats: an autoradiographic study. Exp Brain Res, v.24, n.5, p.523-9, 1976.

Hirasawa, H.; Shiells, R. e Yamada, M. A metabotropic glutamate receptor regulates transmitter release from cone presynaptic terminals in carp retinal slices. J Gen Physiol, v.119, n.1, p.55-68, 2002.

Hofbauer, A. e Hollander, H. Synaptic connections of cortical and retinal terminals in the superior colliculus of the rabbit: an electron microscopic double labelling study. Exp Brain Res, v.65, n.1, p.145-55, 1986. 
Hoffpauir, B.K. e Gleason, E.L. Activation of mGluR5 modulates GABA(A) receptor function in retinal amacrine cells. J Neurophysiol, v.88, n.4, p.1766-76, 2002.

Hollmann, M. e Heinemann, S. Cloned glutamate receptors. Annu Rev Neurosci, v.17, p.31108, 1994.

Hollmann, M.; Maron, C. e Heinemann, S. N-glycosylation site tagging suggests a three transmembrane domain topology for the glutamate receptor GluR1. Neuron, v.13, n.6, p.1331-43, 1994.

Hollmann, M.; O'shea-Greenfield, A.; Rogers, S.W. e Heinemann, S. Cloning by functional expression of a member of the glutamate receptor family. Nature, v.342, n.6250, p.643-8, 1989.

Hudtloff, C. e Thomsen, C. Autoradiographic visualization of group III metabotropic glutamate receptors using $[3 \mathrm{H}]-\mathrm{L}-2$-amino-4-phosphonobutyrate. Br J Pharmacol, v.124, n.5, p.971-7, 1998.

Huges, W.T. e Cox, F. Are blood gas machines safe for use in the intensive care nursery? Pediatrics, v.60, n.5, p.760-1, 1977.

Hunt, S.P. e Kunzle, H. Observations on the projections and intrinsic organization of the pigeon optic tectum: an autoradiographic study based on anterograde and retrograde, axonal and dendritic flow. J Comp Neurol, v.170, n.2, p.153-72, 1976.

Huntley, G.W.; Rogers, S.W.; Moran, T.; Janssen, W.; Archin, N.; Vickers, J.C.; Cauley, K.; Heinemann, S.F. e Morrison, J.H. Selective distribution of kainate receptor subunit immunoreactivity in monkey neocortex revealed by a monoclonal antibody that recognizes glutamate receptor subunits GluR5/6/7. J Neurosci, v.13, n.7, p.2965-81, 1993.

Ikeda, K.; Nagasawa, M.; Mori, H.; Araki, K.; Sakimura, K.; Watanabe, M.; Inoue, Y. e Mishina, M. Cloning and expression of the epsilon 4 subunit of the NMDA receptor channel. FEBS Lett, v.313, n.1, p.34-8, 1992.

Ito, M. Long-term depression. Annu Rev Neurosci, v.12, p.85-102, 1989.

Iwasaki, Y.; Ikeda, K.; Shiojima, T. e Kinoshita, M. CNQX prevents spinal motor neuron death following sciatic nerve transection in newborn rats. J Neurol Sci, v.134, n.1-2, p.21-5, 1995.

Jeon, C.J.; Gurski, M.R. e Mize, R.R. Glutamate containing neurons in the cat superior colliculus revealed by immunocytochemistry. Vis Neurosci, v.14, n.2, p.387-93, 1997a.

Jeon, C.J.; Hartman, M.K. e Mize, R.R. Glutamate-like immunoreactivity in the cat superior colliculus and visual cortex: further evidence that glutamate is the neurotransmitter of the corticocollicular pathway. Vis Neurosci, v.14, n.1, p.27-37, 1997b.

Jones, B.E. e Yang, T.Z. The efferent projections from the reticular formation and the locus coeruleus studied by anterograde and retrograde axonal transport in the rat. J Comp Neurol, v.242, n.1, p.56-92, 1985.

Kalda, A.; Kaasik, A.; Vassiljev, V.; Pokk, P. e Zharkovsky, A. Neuroprotective action of group I metabotropic glutamate receptor agonists against oxygen-glucose deprivationinduced neuronal death. Brain Res, v.853, n.2, p.370-3, 2000. 
Karten, H.J.; Cox, K. e Mpodozis, J. Two distinct populations of tectal neurons have unique connections within the retinotectorotundal pathway of the pigeon (Columba livia). J Comp Neurol, v.387, n.3, p.449-65, 1997.

Kawabata, S.; Tsutsumi, R.; Kohara, A.; Yamaguchi, T.; Nakanishi, S. e Okada, M. Control of calcium oscillations by phosphorylation of metabotropic glutamate receptors. Nature, v.383, n.6595, p.89-92, 1996.

Keinanen, K.; Wisden, W.; Sommer, B.; Werner, P.; Herb, A.; Verdoorn, T.A.; Sakmann, B. e Seeburg, P.H. A family of AMPA-selective glutamate receptors. Science, v.249, n.4968, p.556-60, 1990.

Kew, J.N. e Kemp, J.A. Ionotropic and metabotropic glutamate receptor structure and pharmacology. Psychopharmacology (Berl), v.179, n.1, p.4-29, 2005.

Kihara, A.H.; Moriscot, A.S.; Ferreira, P.J. e Hamassaki, D.E. Protecting RNA in fixed tissue: an alternative method for LCM users. J Neurosci Methods, v.148, n.2, p.103-7, 2005.

Kim, C.H.; Lee, J.; Lee, J.Y. e Roche, K.W. Metabotropic glutamate receptors: Phosphorylation and receptor signaling. J Neurosci Res, 2007.

Kim, M.A. e Jeon, C.J. Metabotropic glutamate receptor mGluR2/3 immunoreactivity in the mouse superior colliculus: co-localization with calbindin D28K. Neuroreport, v.10, n.6, p.1341-6, 1999.

Kind, P.C. e Neumann, P.E. Plasticity: downstream of glutamate. Trends Neurosci, v.24, n.10, p.553-5, 2001.

King, S.M. Escape-related behaviours in an unstable, elevated and exposed environment. II. Long-term sensitization after repetitive electrical stimulation of the rodent midbrain defence system. Behav Brain Res, v.98, n.1, p.127-42, 1999.

Kinzie, J.M.; Saugstad, J.A.; Westbrook, G.L. e Segerson, T.P. Distribution of metabotropic glutamate receptor 7 messenger RNA in the developing and adult rat brain. Neuroscience, v.69, n.1, p.167-76, 1995.

Klausnitzer, J.; Kulla, A. e Manahan-Vaughan, D. Role of the group III metabotropic glutamate receptor in LTP, depotentiation and LTD in dentate gyrus of freely moving rats. Neuropharmacology, v.46, n.2, p.160-70, 2004.

Knopfel, T. e Uusisaari, M. Modulation of excitation by metabotropic glutamate receptors. Results Probl Cell Differ, v.44, p.163-75, 2008.

Knudsen, E.I. Auditory and visual maps of space in the optic tectum of the owl. J Neurosci, v.2, n.9, p.1177-94, 1982.

Koerner, J.F. e Cotman, C.W. Micromolar L-2-amino-4-phosphonobutyric acid selectively inhibits perforant path synapses from lateral entorhinal cortex. Brain Res, v.216, n.1, p.192-8, 1981.

Kolmac, C.I.; Power, B.D. e Mitrofanis, J. Dorsal thalamic connections of the ventral lateral geniculate nucleus of rats. J Neurocytol, v.29, n.1, p.31-41, 2000.

Kosinski, C.M.; Risso Bradley, S.; Conn, P.J.; Levey, A.I.; Landwehrmeyer, G.B.; Penney, J.B., Jr.; Young, A.B. e Standaert, D.G. Localization of metabotropic glutamate receptor 7 
mRNA and mGluR7a protein in the rat basal ganglia. J Comp Neurol, v.415, n.2, p.266-84, 1999.

Koulen, P.; Malitschek, B.; Kuhn, R.; Wassle, H. e Brandstatter, J.H. Group II and group III metabotropic glutamate receptors in the rat retina: distributions and developmental expression patterns. Eur J Neurosci, v.8, n.10, p.2177-87, 1996.

Kreitzer, A.C. e Regehr, W.G. Retrograde inhibition of presynaptic calcium influx by endogenous cannabinoids at excitatory synapses onto Purkinje cells. Neuron, v.29, n.3, p.717-27, 2001.

Krieg, W.J. Connections of the cerebral cortex; the macaque; frontal areas and subareas. J Comp Neurol, v.91, n.3, p.467-506, illust, 1949.

Kuryatov, A.; Laube, B.; Betz, H. e Kuhse, J. Mutational analysis of the glycine-binding site of the NMDA receptor: structural similarity with bacterial amino acid-binding proteins. Neuron, v.12, n.6, p.1291-300, 1994.

Kutsuwada, T.; Kashiwabuchi, N.; Mori, H.; Sakimura, K.; Kushiya, E.; Araki, K.; Meguro, H.; Masaki, H.; Kumanishi, T.; Arakawa, M. e Et Al. Molecular diversity of the NMDA receptor channel. Nature, v.358, n.6381, p.36-41, 1992.

Lafon-Cazal, M.; Fagni, L.; Guiraud, M.J.; Mary, S.; Lerner-Natoli, M.; Pin, J.P.; Shigemoto, R. e Bockaert, J. mGluR7-like metabotropic glutamate receptors inhibit NMDA-mediated excitotoxicity in cultured mouse cerebellar granule neurons. Eur J Neurosci, v.11, n.2, p.663$72,1999$.

Lam, H.M.; Chiu, J.; Hsieh, M.H.; Meisel, L.; Oliveira, I.C.; Shin, M. e Coruzzi, G. Glutamatereceptor genes in plants. Nature, v.396, n.6707, p.125-6, 1998.

Lam, K.; Sefton, A.J. e Bennett, M.R. Loss of axons from the optic nerve of the rat during early postnatal development. Brain Res, v.255, n.3, p.487-91, 1982.

Lan, J.Y.; Skeberdis, V.A.; Jover, T.; Zheng, X.; Bennett, M.V. e Zukin, R.S. Activation of metabotropic glutamate receptor 1 accelerates NMDA receptor trafficking. J Neurosci, v.21, n.16, p.6058-68, 2001.

Langer, T.P. e Lund, R.D. The upper layers of the superior colliculus of the rat: a Golgi study. J Comp Neurol, v.158, n.4, p.418-35, 1974.

Lashley, K.S. The mecanism of vision. VII. The projection of the retina upon the primary optic centers in the rat. J Comp Neurol, v.59, p.341-373, 1934.

Lavail, J.H. e Cowan, W.M. The development of the chick optic tectum. I. Normal morphology and cytoarchitectonic development. Brain Res, v.28, n.3, p.391-419, 1971.

Lea, P.M.T. e Faden, A.I. Modulation of metabotropic glutamate receptors as potential treatment for acute and chronic neurodegenerative disorders. Drug News Perspect, v.16, n.8, p.513-22, 2003.

Lee, H.G.; Zhu, X.; O'neill, M.J.; Webber, K.; Casadesus, G.; Marlatt, M.; Raina, A.K.; Perry, G. e Smith, M.A. The role of metabotropic glutamate receptors in Alzheimer's disease. Acta Neurobiol Exp (Wars), v.64, n.1, p.89-98, 2004. 
Lee, H.K. Synaptic plasticity and phosphorylation. Pharmacol Ther, v.112, n.3, p.810-32, 2006.

Legg, C.R. An autoradiographic study of the efferent projections of the ventral lateral geniculate nucleus of the hooded rat. Brain Res, v.170, n.2, p.349-52, 1979.

Lenz, G.; Manozzo, L.; Gottardo, S.; Achaval, M.; Salbego, C. e Rodnight, R. Temporal profiles of the in vitro phosphorylation rate and immunocontent of glial fibrillary acidic protein (GFAP) after kainic acid-induced lesions in area CA1 of the rat hippocampus: demonstration of a novel phosphoprotein associated with gliosis. Brain Res, v.764, n.1-2, p.188-96, 1997.

Li, X.; Hallqvist, A.; Jacobson, I.; Orwar, O. e Sandberg, M. Studies on the identity of the rat optic nerve transmitter. Brain Res, v.706, n.1, p.89-96, 1996.

Liang, Y.C.; Huang, C.C. e Hsu, K.S. Characterization of long-term potentiation of primary afferent transmission at trigeminal synapses of juvenile rats: essential role of subtype 5 metabotropic glutamate receptors. Pain, v.114, n.3, p.417-28, 2005.

Lieberman, A.R. The axon reaction: a review of the principal features of perikaryal responses to axon injury. Int Rev Neurobiol, v.14, p.49-124, 1971.

Linden, A.M.; Johnson, B.G.; Peters, S.C.; Shannon, H.E.; Tian, M.; Wang, Y.; Yu, J.L.; Koster, A.; Baez, M. e Schoepp, D.D. Increased anxiety-related behavior in mice deficient for metabotropic glutamate 8 (mGlu8) receptor. Neuropharmacology, v.43, n.2, p.251-9, 2002.

Linden, D.J. e Connor, J.A. Participation of postsynaptic PKC in cerebellar long-term depression in culture. Science, v.254, n.5038, p.1656-9, 1991.

Linden, R. e Perry, V.H. Massive retinotectal projection in rats. Brain Res, v.272, n.1, p.1459, 1983.

Lo, F.S.; Cork, R.J. e Mize, R.R. Physiological properties of neurons in the optic layer of the rat's superior colliculus. J Neurophysiol, v.80, n.1, p.331-43, 1998.

Lu, Y.M.; Jia, Z.; Janus, C.; Henderson, J.T.; Gerlai, R.; Wojtowicz, J.M. e Roder, J.C. Mice lacking metabotropic glutamate receptor 5 show impaired learning and reduced CA1 longterm potentiation (LTP) but normal CA3 LTP. J Neurosci, v.17, n.13, p.5196-205, 1997.

Luksch, H. Cytoarchitecture of the avian optic tectum: neuronal substrate for cellular computation. Rev Neurosci, v.14, n.1-2, p.85-106, 2003.

Luksch, H. e Poll, A. Early enucleation does not alter the gross morphology of identified projection neurons in the chicken optic tectum. Neurosci Lett, v.331, n.1, p.41-4, 2002.

Lund, J.S.; Remington, F.L. e Lund, R.D. Differential central distribution of optic nerve components in the rat. Brain Res, v.116, n.1, p.83-100, 1976.

Lund, R.D. Synaptic patterns of the superficial layers of the superior colliculus of the rat. J Comp Neurol, v.135, n.2, p.179-208, 1969.

Lund, R.D. Anatomic studies on the superior colliculus. Invest Ophthalmol, v.11, n.6, p.434$41,1972$.

Lund, R.D. e Cunningham, T.J. Aspects of synaptic and laminar organization of the mammalian lateral geniculate body. Invest Ophthalmol, v.11, n.5, p.291-302, 1972. 
Lund, R.D. e Lund, J.S. Modifications of synaptic patterns in the superior colliculus of the rat during development and following deafferentation. Vision Res, v.Suppl 3, p.281-98, 1971a.

Lund, R.D. e Lund, J.S. Synaptic adjustment after deafferentation of the superior colliculus of the rat. Science, v.171, n.973, p.804-7, 1971b.

Lund, R.D. e Lund, J.S. Plasticity in the developing visual system: the effects of retinal lesions made in young rats. J Comp Neurol, v.169, n.2, p.133-54, 1976.

Lund, R.D.; Lund, J.S. e Wise, R.P. The organization of the retinal projection to the dorsal lateral geniculate nucleus in pigmented and albino rats. J Comp Neurol, v.158, n.4, p.383403, 1974.

Maiese, K.; Chong, Z.Z. e Li, F. Driving cellular plasticity and survival through the signal transduction pathways of metabotropic glutamate receptors. Curr Neurovasc Res, v.2, n.5, p.425-46, 2005.

Maiese, K.; Greenberg, R.; Boccone, L. e Swiriduk, M. Activation of the metabotropic glutamate receptor is neuroprotective during nitric oxide toxicity in primary hippocampal neurons of rats. Neurosci Lett, v.194, n.3, p.173-6, 1995.

Maiese, K.; Swiriduk, M. e Tenbroeke, M. Cellular mechanisms of protection by metabotropic glutamate receptors during anoxia and nitric oxide toxicity. J Neurochem, v.66, n.6, p.241928, 1996.

Mannaioni, G.; Marino, M.J.; Valenti, O.; Traynelis, S.F. e Conn, P.J. Metabotropic glutamate receptors 1 and 5 differentially regulate CA1 pyramidal cell function. J Neurosci, v.21, n.16, p.5925-34, 2001.

Mano, I. e Teichberg, V.I. A tetrameric subunit stoichiometry for a glutamate receptorchannel complex. Neuroreport, v.9, n.2, p.327-31, 1998.

Mantyh, P.W. e Hunt, S.P. Changes in $3 \mathrm{H}$-substance $\mathrm{P}$ receptor binding in the rat brain after kainic acid lesion of the corpus striatum. J Neurosci, v.6, n.6, p.1537-44, 1986.

Marc, R.E.; Liu, W.L.; Kalloniatis, M.; Raiguel, S.F. e Van Haesendonck, E. Patterns of glutamate immunoreactivity in the goldfish retina. J Neurosci, v.10, n.12, p.4006-34, 1990.

Martin, L.J.; Al-Abdulla, N.A.; Brambrink, A.M.; Kirsch, J.R.; Sieber, F.E. e Portera-Cailliau, C. Neurodegeneration in excitotoxicity, global cerebral ischemia, and target deprivation: A perspective on the contributions of apoptosis and necrosis. Brain Res Bull, v.46, n.4, p.281309, 1998.

Martin, L.J.; Blackstone, C.D.; Huganir, R.L. e Price, D.L. Cellular localization of a metabotropic glutamate receptor in rat brain. Neuron, v.9, n.2, p.259-70, 1992.

Mason, R. e Groos, G.A. Cortico-recipient and tecto-recipient visual zones in the rat's lateral posterior (pulvinar) nucleus: an anatomical study. Neurosci Lett, v.25, n.2, p.107-12, 1981.

Masugi, M.; Yokoi, M.; Shigemoto, R.; Muguruma, K.; Watanabe, Y.; Sansig, G.; Van Der Putten, H. e Nakanishi, S. Metabotropic glutamate receptor subtype 7 ablation causes deficit in fear response and conditioned taste aversion. J Neurosci, v.19, n.3, p.955-63, 1999. 
Mathers, L.H., Jr. Retinal and visual cortical projection to the superior colliculus of the rabbit. Exp Neurol, v.57, n.3, p.698-712, 1977.

Matthews, M.A. Death of the central neuron: an electron microscopic study of thalamic retrograde degeneration following cortical ablation. J Neurocytol, v.2, n.3, p.265-88, 1973.

Mayer, M.L. e Westbrook, G.L. The physiology of excitatory amino acids in the vertebrate central nervous system. Prog Neurobiol, v.28, n.3, p.197-276, 1987.

Mayer, M.L.; Westbrook, G.L. e Guthrie, P.B. Voltage-dependent block by Mg2+ of NMDA responses in spinal cord neurones. Nature, v.309, n.5965, p.261-3, 1984.

Mcdonald, J.W. Pharmacology of N-methyl-D-aspartate toxicity in the developing central nervous system. University of Michigan., Michigan, 1989.

Mcdonald, J.W. e Schoepp, D.D. The metabotropic excitatory amino acid receptor agonist 1S,3R-ACPD selectively potentiates $\mathrm{N}$-methyl-D-aspartate-induced brain injury. Eur J Pharmacol, v.215, n.2-3, p.353-4, 1992.

Mcdonald, J.W.; Silverstein, F.S. e Johnston, M.V. Neurotoxicity of N-methyl-D-aspartate is markedly enhanced in developing rat central nervous system. Brain Res, v.459, n.1, p.200-3, 1988.

Mchaffie, J.G. e Stein, B.E. Eye movements evoked by electrical stimulation in the superior colliculus of rats and hamsters. Brain Res, v.247, n.2, p.243-53, 1982.

Medhurst, A.D.; Harrison, D.C.; Read, S.J.; Campbell, C.A.; Robbins, M.J. e Pangalos, M.N. The use of TaqMan RT-PCR assays for semiquantitative analysis of gene expression in CNS tissues and disease models. J Neurosci Methods, v.98, n.1, p.9-20, 2000.

Meguro, H.; Mori, H.; Araki, K.; Kushiya, E.; Kutsuwada, T.; Yamazaki, M.; Kumanishi, T.; Arakawa, M.; Sakimura, K. e Mishina, M. Functional characterization of a heteromeric NMDA receptor channel expressed from cloned cDNAs. Nature, v.357, n.6373, p.70-4, 1992.

Meinecke, D.L. e Peters, A. GABA immunoreactive neurons in rat visual cortex. J Comp Neurol, v.261, n.3, p.388-404, 1987.

Meldrum, B.S. Glutamate as a neurotransmitter in the brain: review of physiology and pathology. J Nutr, v.130, n.4S Suppl, p.1007S-15S, 2000.

Meldrum, B.S.; Akbar, M.T. e Chapman, A.G. Glutamate receptors and transporters in genetic and acquired models of epilepsy. Epilepsy Res, v.36, n.2-3, p.189-204, 1999.

Meloni, E.G. e Davis, M. GABA in the deep layers of the superior Colliculus/Mesencephalic reticular formation mediates the enhancement of startle by the dopamine D1 receptor agonist SKF 82958 in rats. J Neurosci, v.20, n.14, p.5374-81, 2000.

Mentis, G.Z.; Greensmith, L. e Vrbova, G. Motoneurons destined to die are rescued by blocking N-methyl-D-aspartate receptors by MK-801. Neuroscience, v.54, n.2, p.283-5, 1993.

Miles, R. e Poncer, J.C. Metabotropic glutamate receptors mediate a post-tetanic excitation of guinea-pig hippocampal inhibitory neurones. J Physiol, v.463, p.461-73, 1993.

Miller, M.W. e Vogt, B.A. The postnatal growth of the callosal connections of primary and secondary visual cortex in the rat. Brain Res, v.316, n.2, p.304-9, 1984. 
Mitchell, S.J. e Silver, R.A. Glutamate spillover suppresses inhibition by activating presynaptic mGluRs. Nature, v.404, n.6777, p.498-502, 2000.

Monaghan, D.T.; Bridges, R.J. e Cotman, C.W. The excitatory amino acid receptors: their classes, pharmacology, and distinct properties in the function of the central nervous system. Annu Rev Pharmacol Toxicol, v.29, p.365-402, 1989.

Montero, V.M. Topography of the cortico-cortical connections from the striate cortex in the cat. Brain Behav Evol, v.18, n.4, p.194-218, 1981.

Montero, V.M.; Rojas, A. e Torrealba, F. Retinotopic organization of striate and peristriate visual cortex in the albino rat. Brain Res, v.53, n.1, p.197-201, 1973.

Monyer, H.; Sprengel, R.; Schoepfer, R.; Herb, A.; Higuchi, M.; Lomeli, H.; Burnashev, N.; Sakmann, B. e Seeburg, P.H. Heteromeric NMDA receptors: molecular and functional distinction of subtypes. Science, v.256, n.5060, p.1217-21, 1992.

Moore, R.Y.; Weis, R. e Moga, M.M. Efferent projections of the intergeniculate leaflet and the ventral lateral geniculate nucleus in the rat. J Comp Neurol, v.420, n.3, p.398-418, 2000.

Mori, H. e Mishina, M. Structure and function of the NMDA receptor channel. Neuropharmacology, v.34, n.10, p.1219-37, 1995.

Morino, P.; Bahro, M.; Cuenod, M. e Streit, P. Glutamate-like Immunoreactivity in the Pigeon Optic Tectum and Effects of Retinal Ablation. Eur J Neurosci, v.3, n.4, p.366-378, 1991.

Moriyama, Y.; Hayashi, M.; Yamada, H.; Yatsushiro, S.; Ishio, S. e Yamamoto, A. Synapticlike microvesicles, synaptic vesicle counterparts in endocrine cells, are involved in a novel regulatory mechanism for the synthesis and secretion of hormones. J Exp Biol, v.203, n.Pt 1, p.117-25, 2000.

Moriyoshi, K.; Masu, M.; Ishii, T.; Shigemoto, R.; Mizuno, N. e Nakanishi, S. Molecular cloning and characterization of the rat NMDA receptor. Nature, v.354, n.6348, p.31-7, 1991.

Mutoh, H.; Yuan, Q. e Knopfel, T. Long-term depression at olfactory nerve synapses. J Neurosci, v.25, n.17, p.4252-9, 2005.

Naie, K.; Tsanov, M. e Manahan-Vaughan, D. Group I metabotropic glutamate receptors enable two distinct forms of long-term depression in the rat dentate gyrus in vivo. Eur $\mathrm{J}$ Neurosci, v.25, n.11, p.3264-75, 2007.

Nakajima, Y.; Iwakabe, H.; Akazawa, C.; Nawa, H.; Shigemoto, R.; Mizuno, N. e Nakanishi, S. Molecular characterization of a novel retinal metabotropic glutamate receptor mGluR6 with a high agonist selectivity for L-2-amino-4-phosphonobutyrate. J Biol Chem, v.268, n.16, p.11868-73, 1993.

Nakanishi, S. Molecular diversity of glutamate receptors and implications for brain function. Science, v.258, n.5082, p.597-603, 1992.

Nakanishi, S. Second-order neurones and receptor mechanisms in visual- and olfactoryinformation processing. Trends Neurosci, v.18, n.8, p.359-64, 1995.

Neki, A.; Ohishi, H.; Kaneko, T.; Shigemoto, R.; Nakanishi, S. e Mizuno, N. Pre- and postsynaptic localization of a metabotropic glutamate receptor, mGluR2, in the rat brain: an 
immunohistochemical study with a monoclonal antibody. Neurosci Lett, v.202, n.3, p.197200, 1996.

Netzeband, J.G.; Parsons, K.L.; Sweeney, D.D. e Gruol, D.L. Metabotropic glutamate receptor agonists alter neuronal excitability and $\mathrm{Ca} 2+$ levels via the phospholipase $\mathrm{C}$ transduction pathway in cultured Purkinje neurons. J Neurophysiol, v.78, n.1, p.63-75, 1997.

Nicoletti, F.; Battaglia, G.; Storto, M.; Ngomba, R.; Lacovelli, L.; Arcella, A.; Grandini, R.; Sale, P.; Rampello, L.; De Vita, T.; Di Marco, R.; Melchiorri, D. e Bruno, V. Metabotropic glutamate receptors: Beyond the regulation of synaptic transmission. Psychoneuroendocrinology, 2008.

Nicoletti, F.; Bruno, V.; Copani, A.; Casabona, G. e Knopfel, T. Metabotropic glutamate receptors: a new target for the therapy of neurodegenerative disorders? Trends Neurosci, v.19, n.7, p.267-71, 1996.

Niquet, J.; Ben-Ari, Y. e Represa, A. Glial reaction after seizure induced hippocampal lesion: immunohistochemical characterization of proliferating glial cells. J Neurocytol, v.23, n.10, p.641-56, 1994.

O'connor, J.J.; Rowan, M.J. e Anwyl, R. Tetanically induced LTP involves a similar increase in the AMPA and NMDA receptor components of the excitatory postsynaptic current: investigations of the involvement of mGlu receptors. J Neurosci, v.15, n.3 Pt 1, p.2013-20, 1995.

O'connor, T.M. e Wyttenbach, C.R. Cell death in the embryonic chick spinal cord. J Cell Biol, v.60, n.2, p.448-59, 1974.

Ohishi, H.; Akazawa, C.; Shigemoto, R.; Nakanishi, S. e Mizuno, N. Distributions of the mRNAs for L-2-amino-4-phosphonobutyrate-sensitive metabotropic glutamate receptors, mGluR4 and mGluR7, in the rat brain. J Comp Neurol, v.360, n.4, p.555-70, 1995a.

Ohishi, H.; Neki, A. e Mizuno, N. Distribution of a metabotropic glutamate receptor, mGluR2, in the central nervous system of the rat and mouse: an immunohistochemical study with a monoclonal antibody. Neurosci Res, v.30, n.1, p.65-82, 1998.

Ohishi, H.; Nomura, S.; Ding, Y.Q.; Shigemoto, R.; Wada, E.; Kinoshita, A.; Li, J.L.; Neki, A.; Nakanishi, S. e Mizuno, N. Presynaptic localization of a metabotropic glutamate receptor, mGluR7, in the primary afferent neurons: an immunohistochemical study in the rat. Neurosci Lett, v.202, n.1-2, p.85-8, 1995b.

Ohishi, H.; Shigemoto, R.; Nakanishi, S. e Mizuno, N. Distribution of the messenger RNA for a metabotropic glutamate receptor, mGluR2, in the central nervous system of the rat. Neuroscience, v.53, n.4, p.1009-18, 1993a.

Ohishi, H.; Shigemoto, R.; Nakanishi, S. e Mizuno, N. Distribution of the mRNA for a metabotropic glutamate receptor (mGluR3) in the rat brain: an in situ hybridization study. $J$ Comp Neurol, v.335, n.2, p.252-66, 1993b.

Okada, Y. The distribution and function of gamma-aminobutyric acid (GABA) in the superior colliculus. Prog Brain Res, v.90, p.249-62, 1992.

Okamoto, N.; Hori, S.; Akazawa, C.; Hayashi, Y.; Shigemoto, R.; Mizuno, N. e Nakanishi, S. Molecular characterization of a new metabotropic glutamate receptor mGluR7 coupled to inhibitory cyclic AMP signal transduction. J Biol Chem, v.269, n.2, p.1231-6, 1994. 
Olavarria, J. e Montero, V.M. Relation of callosal and striate-extrastriate cortical connections in the rat: morphological definition of extrastriate visual areas. Exp Brain Res, v.54, n.2, p.240-52, 1984.

Olds, M.E. e Olds, J. Approach-escape interactions in rat brain. Am J Physiol, v.203, p.80310, 1962.

Olney, J.W.; Ho, O.L.; Rhee, V. e Degubareff, T. Letter: Neurotoxic effects of glutamate. N Engl J Med, v.289, n.25, p.1374-5, 1973.

Opitz, T. e Reymann, K.G. (1S, 3R)-ACPD protects synaptic transmission from hypoxia in hippocampal slices. Neuropharmacology, v.32, n.1, p.103-4, 1993.

Ortega, F.; Hennequet, L.; Sarria, R.; Streit, P. e Grandes, P. Changes in the pattern of glutamate-like immunoreactivity in rat superior colliculus following retinal and visual cortical lesions. Neuroscience, v.67, n.1, p.125-34, 1995.

Ozawa, S.; Kamiya, H. e Tsuzuki, K. Glutamate receptors in the mammalian central nervous system. Prog Neurobiol, v.54, n.5, p.581-618, 1998.

Parvanelas, A.D., A.; Davies, S.W. The central visual pathways. In: E. S. P. B. V. B. Division) (Ed.). Handbook of Chemical Neuroanatomy, v.7, 1989. The central visual pathways, p.1-141

Pasquier, D.A. e Villar, M.J. Subcortical projections to the lateral geniculate body in the rat. Exp Brain Res, v.48, n.3, p.409-19, 1982.

Paxinos, G. e Watson, C. The Rat Brain: In Steriotaxic coordinates. Burlington, MA. 2005

Peng, Y.W.; Blackstone, C.D.; Huganir, R.L. e Yau, K.W. Distribution of glutamate receptor subtypes in the vertebrate retina. Neuroscience, v.66, n.2, p.483-97, 1995.

Perry, V.H. A tectocortical visual pathway in the rat. Neuroscience, v.5, n.5, p.915-27, 1980.

Perry, V.H. e Cowey, A. Changes in the retino-fugal pathways following cortical and tectal lesions in neonatal and adult rats. Exp Brain Res, v.35, n.1, p.97-108, 1979.

Peters, A.; Feldman, M. e Saldanha, J. The projection of the lateral geniculate nucleus to area 17 of the rat cerebral cortex. II. Terminations upon neuronal perikarya and dendritic shafts. J Neurocytol, v.5, n.1, p.85-107, 1976.

Peters, A. e Feldman, M.L. The projection of the lateral geniculate nucleus to area 17 of the rat cerebral cortex. I. General description. J Neurocytol, v.5, n.1, p.63-84, 1976.

Peters, A. e Kara, D.A. The neuronal composition of area 17 of rat visual cortex. I. The pyramidal cells. J Comp Neurol, v.234, n.2, p.218-41, 1985.

Peters, A.; Kara, D.A. e Harriman, K.M. The neuronal composition of area 17 of rat visual cortex. III. Numerical considerations. J Comp Neurol, v.238, n.3, p.263-74, 1985.

Petralia, R.S. e Wenthold, R.J. Light and electron immunocytochemical localization of AMPAselective glutamate receptors in the rat brain. J Comp Neurol, v.318, n.3, p.329-54, 1992. 
Petzold, A.; Baker, D.; Pryce, G.; Keir, G.; Thompson, E.J. e Giovannoni, G. Quantification of neurodegeneration by measurement of brain-specific proteins. J Neuroimmunol, v.138, n.1-2, p.45-8, 2003.

Pin, J.P. e Duvoisin, R. The metabotropic glutamate receptors: structure and functions. Neuropharmacology, v.34, n.1, p.1-26, 1995.

Pires, R.S.; Ferro, E.S. e Britto, L.R. Expression of the AMPA-type glutamate receptor subunits in the chick optic tectum changes biphasically after retinal deafferentation. Brain Res, v.810, n.1-2, p.283-7, 1998.

Pires, R.S.; Reboucas, N.A.; Duvoisin, R.M. e Britto, L.R. Retinal lesions induce differential changes in the expression of flip and flop isoforms of the glutamate receptor subunit GluR1 in the chick optic tectum. Brain Res Mol Brain Res, v.76, n.2, p.341-6, 2000.

Pizzi, M.; Consolandi, O.; Memo, M. e Spano, P.F. Activation of multiple metabotropic glutamate receptor subtypes prevents NMDA-induced excitotoxicity in rat hippocampal slices. Eur J Neurosci, v.8, n.7, p.1516-21, 1996a.

Pizzi, M.; Galli, P.; Consolandi, O.; Arrighi, V.; Memo, M. e Spano, P.F. Metabotropic and ionotropic transducers of glutamate signal inversely control cytoplasmic $\mathrm{Ca} 2+$ concentration and excitotoxicity in cultured cerebellar granule cells: pivotal role of protein kinase C. Mol Pharmacol, v.49, n.4, p.586-94, 1996b.

Plenz, D. e Kitai, S.T. Regulation of the nigrostriatal pathway by metabotropic glutamate receptors during development. J Neurosci, v.18, n.11, p.4133-44, 1998.

Poli, A.; Beraudi, A.; Villani, L.; Storto, M.; Battaglia, G.; Di Giorgi Gerevini, V.; Cappuccio, I.; Caricasole, A.; D'onofrio, M. e Nicoletti, F. Group II metabotropic glutamate receptors regulate the vulnerability to hypoxic brain damage. J Neurosci, v.23, n.14, p.6023-9, 2003.

Portera-Cailliau, C.; Price, D.L. e Martin, L.J. Non-NMDA and NMDA receptor-mediated excitotoxic neuronal deaths in adult brain are morphologically distinct: further evidence for an apoptosis-necrosis continuum. J Comp Neurol, v.378, n.1, p.88-104, 1997.

Prestige, M.C. e Willshaw, D.J. On a role for competition in the formation of patterned neural connexions. Proc R Soc Lond B Biol Sci, v.190, n.1098, p.77-98, 1975.

Prusky, G.T.; Alam, N.M. e Douglas, R.M. Enhancement of vision by monocular deprivation in adult mice. J Neurosci, v.26, n.45, p.11554-61, 2006.

Quigley, H.A.; Nickells, R.W.; Kerrigan, L.A.; Pease, M.E.; Thibault, D.J. e Zack, D.J. Retinal ganglion cell death in experimental glaucoma and after axotomy occurs by apoptosis. Invest Ophthalmol Vis Sci, v.36, n.5, p.774-86, 1995.

Redgrave, P. e Dean, P. Collicular picrotoxin alleviates akinesia but not sensory neglect in rats with bilateral 6-hydroxydopamine lesions of ventral midbrain. Psychopharmacology (Berl), v.75, n.2, p.204-9, 1981.

Ribak, C.E. e Peters, A. An autoradiographic study of the projections from the lateral geniculate body of the rat. Brain Res, v.92, n.3, p.341-68, 1975.

Riljak, V.; Milotova, M.; Jandova, K.; Pokorny, J. e Langmeier, M. Morphological changes in the hippocampus following nicotine and kainic acid administration. Physiol Res, 2007. 
Roberts, W.A.; Eaton, S.A. e Salt, T.E. Excitatory amino acid receptors mediate synaptic responses to visual stimuli in superior colliculus neurones of the rat. Neurosci Lett, v.129, n.2, p.161-4, 1991.

Rodriguez-Moreno, A.; Sistiaga, A.; Lerma, J. e Sanchez-Prieto, J. Switch from facilitation to inhibition of excitatory synaptic transmission by group I mGluR desensitization. Neuron, v.21, n.6, p.1477-86, 1998.

Romanes, G.J. Motor localization and the effects of nerve injury on the ventral horn cells of the spinal cord. J Anat, v.80, n.Pt 3, p.117-31, 1946.

Romano, C.; Sesma, M.A.; Mcdonald, C.T.; O'malley, K.; Van Den Pol, A.N. e Olney, J.W. Distribution of metabotropic glutamate receptor mGluR5 immunoreactivity in rat brain. $\mathrm{J}$ Comp Neurol, v.355, n.3, p.455-69, 1995.

Rosenmund, C.; Stern-Bach, Y. e Stevens, C.F. The tetrameric structure of a glutamate receptor channel. Science, v.280, n.5369, p.1596-9, 1998.

Rothman, S.M. e Olney, J.W. Excitotoxicity and the NMDA receptor--still lethal after eight years. Trends Neurosci, v.18, n.2, p.57-8, 1995.

Sacaan, A.I. e Schoepp, D.D. Activation of hippocampal metabotropic excitatory amino acid receptors leads to seizures and neuronal damage. Neurosci Lett, v.139, n.1, p.77-82, 1992.

Sagara, Y. e Schubert, D. The activation of metabotropic glutamate receptors protects nerve cells from oxidative stress. J Neurosci, v.18, n.17, p.6662-71, 1998.

Sahibzada, N.; Dean, P. e Redgrave, P. Movements resembling orientation or avoidance elicited by electrical stimulation of the superior colliculus in rats. J Neurosci, v.6, n.3, p.72333, 1986.

Sakurai, T.; Miyamoto, T. e Okada, Y. Reduction of glutamate content in rat superior colliculus after retino-tectal denervation. Neurosci Lett, v.109, n.3, p.299-303, 1990.

Sansig, G.; Bushell, T.J.; Clarke, V.R.; Rozov, A.; Burnashev, N.; Portet, C.; Gasparini, F.; Schmutz, M.; Klebs, K.; Shigemoto, R.; Flor, P.J.; Kuhn, R.; Knoepfel, T.; Schroeder, M.; Hampson, D.R.; Collett, V.J.; Zhang, C.; Duvoisin, R.M.; Collingridge, G.L. e Van Der Putten, $\mathrm{H}$. Increased seizure susceptibility in mice lacking metabotropic glutamate receptor $7 . \mathrm{J}$ Neurosci, v.21, n.22, p.8734-45, 2001.

Saugstad, J.A.; Kinzie, J.M.; Shinohara, M.M.; Segerson, T.P. e Westbrook, G.L. Cloning and expression of rat metabotropic glutamate receptor 8 reveals a distinct pharmacological profile. Mol Pharmacol, v.51, n.1, p.119-25, 1997.

Scanziani, M.; Salin, P.A.; Vogt, K.E.; Malenka, R.C. e Nicoll, R.A. Use-dependent increases in glutamate concentration activate presynaptic metabotropic glutamate receptors. Nature, v.385, n.6617, p.630-4, 1997.

Schmittgen, T.D.; Zakrajsek, B.A.; Mills, A.G.; Gorn, V.; Singer, M.J. e Reed, M.W. Quantitative reverse transcription-polymerase chain reaction to study mRNA decay: comparison of endpoint and real-time methods. Anal Biochem, v.285, n.2, p.194-204, 2000.

Schmued, L.C. e Hopkins, K.J. Fluoro-Jade B: a high affinity fluorescent marker for the localization of neuronal degeneration. Brain Res, v.874, n.2, p.123-30, 2000. 
Schneider, G.E. Two visual systems. Science, v.163, n.870, p.895-902, 1969.

Schoepp, D.D. Unveiling the functions of presynaptic metabotropic glutamate receptors in the central nervous system. J Pharmacol Exp Ther, v.299, n.1, p.12-20, 2001.

Schoepp, D.D. e Conn, P.J. Metabotropic glutamate receptors in brain function and pathology. Trends Pharmacol Sci, v.14, n.1, p.13-20, 1993.

Schoepp, D.D.; Jane, D.E. e Monn, J.A. Pharmacological agents acting at subtypes of metabotropic glutamate receptors. Neuropharmacology, v.38, n.10, p.1431-76, 1999.

Schroder, U.H.; Opitz, T.; Jager, T.; Sabelhaus, C.F.; Breder, J. e Reymann, K.G. Protective effect of group I metabotropic glutamate receptor activation against hypoxic/hypoglycemic injury in rat hippocampal slices: timing and involvement of protein kinase C. Neuropharmacology, v.38, n.2, p.209-16, 1999.

Schwarcz, R.; Brush, G.S.; Foster, A.C. e French, E.D. Seizure activity and lesions after intrahippocampal quinolinic acid injection. Exp Neurol, v.84, n.1, p.1-17, 1984.

Seeburg, P.H. The TINS/TiPS Lecture. The molecular biology of mammalian glutamate receptor channels. Trends Neurosci, v.16, n.9, p.359-65, 1993.

Sefton, A.J. The electrical activity of the anterior colliculus in the rat. Vision Res, v.9, n.2, p.207-22, 1969.

Sefton, A.J.; Lund, R.D. e Perry, V.H. Target regions enhance the outgrowth and survival of ganglion cells in embryonic retina transplanted to cerebral cortex in neonatal rats. Brain Res, v.430, n.1, p.145-9, 1987.

Sefton, A.J.; Mackay-Sim, A.; Baur, L.A. e Cottee, L.J. Cortical projections to visual centres in the rat: an HRP study. Brain Res, v.215, n.1-2, p.1-13, 1981.

Sefton, A.J.D., B. Visual system. In: G. Paxinos (Ed.). The Rat Nervous System. San Diego: Elsevier Academic Press, v.1, 2004. Visual system, p.169-221

Semyanov, A. e Kullmann, D.M. Modulation of GABAergic signaling among interneurons by metabotropic glutamate receptors. Neuron, v.25, n.3, p.663-72, 2000.

Shao, Y. e Mccarthy, K.D. Plasticity of astrocytes. Glia, v.11, n.2, p.147-55, 1994.

Shigemoto, R. e Mizuno, N. Metabotropic glutamate receptors - immunocytochemical and in situ hibridization analyses. In: E. S. B. V. (Ed.). Handbook of Chemical Neuroanatomy, v.18, 2000. Metabotropic glutamate receptors - immunocytochemical and in situ hibridization analyses, p.63-98

Shigemoto, R.; Nakanishi, S. e Mizuno, N. Distribution of the mRNA for a metabotropic glutamate receptor (mGluR1) in the central nervous system: an in situ hybridization study in adult and developing rat. J Comp Neurol, v.322, n.1, p.121-35, 1992.

Shigemoto, R.; Nakaya, Y.; Nomura, S.; Ogawa-Meguro, R.; Ohishi, H.; Kaneko, T.; Nakanishi, S. e Mizuno, N. Immunocytochemical localization of rat substance $P$ receptor in the striatum. Neurosci Lett, v.153, n.2, p.157-60, 1993a. 
Shigemoto, R.; Nomura, S.; Ohishi, H.; Sugihara, H.; Nakanishi, S. e Mizuno, N. Immunohistochemical localization of a metabotropic glutamate receptor, mGluR5, in the rat brain. Neurosci Lett, v.163, n.1, p.53-7, 1993b.

Siegel, S.J.; Janssen, W.G.; Tullai, J.W.; Rogers, S.W.; Moran, T.; Heinemann, S.F. e Morrison, J.H. Distribution of the excitatory amino acid receptor subunits GluR2(4) in monkey hippocampus and colocalization with subunits GluR5-7 and NMDAR1. J Neurosci, v.15, n.4, p.2707-19, 1995.

Siegelbaum, S.A. e Kandel, E.R. Learning-related synaptic plasticity: LTP and LTD. Curr Opin Neurobiol, v.1, n.1, p.113-20, 1991.

Sillito, A.M.; Murphy, P.C. e Salt, T.E. The contribution of the non-N-methyl-D-aspartate group of excitatory amino acid receptors to retinogeniculate transmission in the cat. Neuroscience, v.34, n.2, p.273-80, 1990.

Silveira Dos Santos Bredariol, A. e Hamassaki-Britto, D.E. Ionotropic glutamate receptors during the development of the chick retina. J Comp Neurol, v.441, n.1, p.58-70, 2001.

Smith, S.A. e Bedi, K.S. Unilateral eye enucleation in adult rats causes neuronal loss in the contralateral superior colliculus. J Anat, v.190 ( Pt 4), p.481-90, 1997.

Snyder, E.M.; Philpot, B.D.; Huber, K.M.; Dong, X.; Fallon, J.R. e Bear, M.F. Internalization of ionotropic glutamate receptors in response to mGluR activation. Nat Neurosci, v.4, n.11, p.1079-85, 2001.

Sommer, B.; Keinanen, K.; Verdoorn, T.A.; Wisden, W.; Burnashev, N.; Herb, A.; Kohler, M.; Takagi, T.; Sakmann, B. e Seeburg, P.H. Flip and flop: a cell-specific functional switch in glutamate-operated channels of the CNS. Science, v.249, n.4976, p.1580-5, 1990.

Sosa, R. e Gleason, E. Activation of mGluR5 modulates Ca2+ currents in retinal amacrine cells from the chick. Vis Neurosci, v.21, n.6, p.807-16, 2004.

Sparks, D.L. e Nelson, J.S. Sensory and motor maps in the mammalian superior colliculus. Trends Neurosci, v.10, p.312-317, 1987.

Steinhauser, C. e Gallo, V. News on glutamate receptors in glial cells. Trends Neurosci, v.19, n.8, p.339-45, 1996.

Stewart, G.R.; Price, M.; Olney, J.W.; Hartman, B.K. e Cozzari, C. N-methylaspartate: an effective tool for lesioning basal forebrain cholinergic neurons of the rat. Brain Res, v.369, n.1-2, p.377-82, 1986.

Stone, J.; Dreher, B. e Leventhal, A. Hierarchical and parallel mechanisms in the organization of visual cortex. Brain Res, v.180, n.3, p.345-94, 1979.

Storm-Mathisen, J. Glutamic acid and excitatory nerve endings: reduction of glutamic acid uptake after axotomy. Brain Res, v.120, n.2, p.379-86, 1977.

Striedinger, K.; Petrasch-Parwez, E.; Zoidl, G.; Napirei, M.; Meier, C.; Eysel, U.T. e Dermietzel, R. Loss of connexin36 increases retinal cell vulnerability to secondary cell loss. Eur J Neurosci, v.22, n.3, p.605-16, 2005.

Sumitomo, I.; Sugitani, M.; Fukuda, Y. e Iwama, K. Properties of cells responding to visual stimuli in the rat ventral lateral geniculate nucleus. Exp Neurol, v.66, n.3, p.721-36, 1979. 
Swanson, C.J.; Bures, M.; Johnson, M.P.; Linden, A.M.; Monn, J.A. e Schoepp, D.D. Metabotropic glutamate receptors as novel targets for anxiety and stress disorders. Nat Rev Drug Discov, v.4, n.2, p.131-44, 2005.

Takacs, J.; Markova, L.; Borostyankoi, Z.; Gorcs, T.J. e Hamori, J. Metabotrop glutamate receptor type 1a expressing unipolar brush cells in the cerebellar cortex of different species: a comparative quantitative study. J Neurosci Res, v.55, n.6, p.733-48, 1999.

Takahashi, T. The organization of the lateral thalamus of the hooded rat. J Comp Neurol, v.231, n.3, p.281-309, 1985.

Tanabe, Y.; Masu, M.; Ishii, T.; Shigemoto, R. e Nakanishi, S. A family of metabotropic glutamate receptors. Neuron, v.8, n.1, p.169-79, 1992.

Tanabe, Y.; Nomura, A.; Masu, M.; Shigemoto, R.; Mizuno, N. e Nakanishi, S. Signal transduction, pharmacological properties, and expression patterns of two rat metabotropic glutamate receptors, mGluR3 and mGluR4. J Neurosci, v.13, n.4, p.1372-8, 1993.

Tasca, C.I.; Cardoso, L.F.; Vendite, D. e Souza, D.O. Study of adenosine A2 receptors in membrane preparations from optic tectum of chicks. Neurochem Res, v.24, n.8, p.1067-74, 1999.

Thomas, H.C. e Espinoza, S.G. Relationships between interhemispheric cortical connections and visual areas in hooded rats. Brain Res, v.417, n.2, p.214-24, 1987.

Thompson, H.; Neale, S.A. e Salt, T.E. Activation of Group II and Group III metabotropic glutamate receptors by endogenous ligand(s) and the modulation of synaptic transmission in the superficial superior colliculus. Neuropharmacology, v.47, n.6, p.822-32, 2004.

Thomsen, C. The L-AP4 receptor. Gen Pharmacol, v.29, n.2, p.151-8, 1997.

Thurlow, G.A. e Cooper, R.M. Metabolic activity in striate and extrastriate cortex in the hooded rat: contralateral and ipsilateral eye input. J Comp Neurol, v.274, n.4, p.595-607, 1988.

Tingley, W.G.; Roche, K.W.; Thompson, A.K. e Huganir, R.L. Regulation of NMDA receptor phosphorylation by alternative splicing of the C-terminal domain. Nature, v.364, n.6432, p.703, 1993.

Torvik, A. e Skjorten, F. Electron microscopic observations on nerve cell regeneration and degeneration after axon lesions. I. Changes in the nerve cell cytoplasm. Acta Neuropathol (Berl), v.17, n.3, p.248-64, 1971.

Tsacopoulos, M. Metabolic signaling between neurons and glial cells: a short review. J Physiol Paris, v.96, n.3-4, p.283-8, 2002.

Tsang, Y.-C. Visual centers in blinded rats. Journal of Comparative Neurology, v.150, p.211261, 1937.

Valverde, F. The neuropil in superficial layers of the superior colliculus of the mouse. A correlated Golgi and electron microscopic study. Z Anat Entwicklungsgesch, v.142, n.2, p.117-47, 1973. 
Van Lookeren Campagne, M.; Lucassen, P.J.; Vermeulen, J.P. e Balazs, R. NMDA and kainate induce internucleosomal DNA cleavage associated with both apoptotic and necrotic cell death in the neonatal rat brain. Eur J Neurosci, v.7, n.7, p.1627-40, 1995a.

Van Lookeren Campagne, M.; Vermeulen, J.P.; Boer, G.J. e Balazs, R. Treatment with NMDA receptor antagonists does not affect developmental changes in NMDA receptor properties in vivo. Neurochem Int, v.27, n.4-5, p.355-66, 1995b.

Vanegas, H. Comparative neurology of the optic tectum. 1984

Vos, P.E.; Zwienenberg, M.; O'hannian, K.L. e Muizelaar, J.P. Subarachnoid haemorrhage following rupture of an ophthalmic artery aneurysm presenting as traumatic brain injury. Clin Neurol Neurosurg, v.102, n.1, p.29-32, 2000.

Watkins, J.C. e Jane, D.E. The glutamate story. Br J Pharmacol, v.147 Suppl 1, p.S100-8, 2006.

Werner, L.; Hedlich, A. e Winkelmann, E. [Types of neurons in the visual cortex of the rat, identified in Nissl- and deimpregnated Golgi preparations]. J Hirnforsch, v.26, n.2, p.173-86, 1985.

White, A.M.; Kylanpaa, R.A.; Christie, L.A.; Mcintosh, S.J.; Irving, A.J. e Platt, B. Presynaptic group I metabotropic glutamate receptors modulate synaptic transmission in the rat superior colliculus via 4-AP sensitive K(+) channels. Br J Pharmacol, v.140, n.8, p.1421-33, 2003.

Winder, D.G. e Conn, P.J. Roles of metabotropic glutamate receptors in glial function and glial-neuronal communication. J Neurosci Res, v.46, n.2, p.131-7, 1996.

Winder, D.G.; Ritch, P.S.; Gereau, R.W.T. e Conn, P.J. Novel glial-neuronal signalling by coactivation of metabotropic glutamate and beta-adrenergic receptors in rat hippocampus. $J$ Physiol, v.494 ( Pt 3), p.743-55, 1996.

Yao, H.H.; Ding, J.H.; Zhou, F.; Wang, F.; Hu, L.F.; Sun, T. e Hu, G. Enhancement of glutamate uptake mediates the neuroprotection exerted by activating group II or III metabotropic glutamate receptors on astrocytes. J Neurochem, v.92, n.4, p.948-61, 2005.

Zhang, C. e Schmidt, J.T. Adenosine A1 and class II metabotropic glutamate receptors mediate shared presynaptic inhibition of retinotectal transmission. J Neurophysiol, v.82, n.6, p.2947-55, 1999.

Zilles, K.; Bauschulte, C. e Becker, C.M. Alterations of the retina in chick embryos induced by systemic alpha-bungarotoxin application. Anat Embryol (Berl), v.171, n.1, p.97-104, 1985.

Zilles, K.; Zilles, B. e Schleicher, A. A quantitative approach to cytoarchitectonics. VI. The areal pattern of the cortex of the albino rat. Anat Embryol (Berl), v.159, n.3, p.335-60, 1980.

Zipfel, G.J.; Babcock, D.J.; Lee, J.M. e Choi, D.W. Neuronal apoptosis after CNS injury: the roles of glutamate and calcium. J Neurotrauma, v.17, n.10, p.857-69, 2000. 